\title{
Verdade ou Mentira? \\ Considerações sobre o flagrante, o pseudoflagrante e a composição na fotografia de German Lorca
}

\begin{abstract}
Dissertação apresentada à Área de Concentração: Artes Plásticas da Escola de Comunicações e Artes da Universidade de São Paulo, como exigência parcial para obtenção do Título de Mestre em Artes, sob a orientação do Prof. Dr. Domingos Tadeu Chiarelli.
\end{abstract}

São Paulo 


\section{Resumo}

Esta pesquisa intitulada Verdade ou mentira? Considerações sobre o flagrante, o pseudoflagrante e a composição na fotografia de German Lorca, tem como assunto a fotografia de rua que o fotógrafo paulistano German Lorca realizou entre o final da década de 1940 e início dos anos 1950, no âmbito do Foto-Cine Clube Bandeirante.

O estudo demonstra a maneira como Lorca utiliza-se do flagrante e de seu falseamento (denominado livremente de pseudoflagrante na dissertação), muitas vezes enfatizando a composição da fotografia por meio do corte.

A fim de atingir esse objetivo a dissertação fundamenta-se em questões que remontam à tradição da busca da representação do movimento na arte ocidental, passando pela fotografia de rua que vem sendo praticada desde meados do século XIX, no exterior e no Brasil. Assim, mostra como noções implícitas nesse amplo contexto teriam servido de parâmetros para a produção das cenas cotidianas de German Lorca, dentro da fotografia moderna brasileira.

Palavras-chave: German Lorca, flagrante, pseudoflagrante, fotografia de rua, fotografia moderna brasileira. 


\section{ABSTRACT}

This research is called Verdade ou Mentira? Considerações sobre o flagrante, o pseudoflagrante e a composição na fotografia de German Lorca (True or False? Considerations on The Snapshot, The Pseudosnapshot and The Composition in German Lorca's Photography). The research has as it subject the street photographs taken by Lorca - a Sao Paulo photographer -, from the late 1940s to the early 1950s, within the scope of the Foto-Cine Clube Bandeirante (Bandeirante Photo-Cine Club).

The study shows how Lorca uses the snapshot and its forgery (loosely called pseudosnaphot in this dissertation), often emphasizing the photograph's composition by means of the 'cut'.

To meet this objective, the dissertation is based on issues that go back to western art's traditional search to represent movement, through street photographs that have been taken since the mid-nineteenth century, both in Brazil and abroad. In this way, it shows how implicit notions in this broad context would have served as parameters for German Lorca's production of everyday scenes, within modern Brazilian photography.

Key words: German Lorca, snapshot, pseudosnapshot, street photography, modern Brazilian photography. 
Para a minha querida mãe, Rosa Mir. 


\section{AGRADECIMENTOS}

Agradeço:

Especialmente aos meus pais, Rosa Mir e Edson, pelo apoio irrestrito, compreensão e carinho que tiveram comigo durante todo o processo de minha pesquisa.

Ao Prof. Dr. Domingos Tadeu Chiarelli, meu orientador, por me guiar com mão segura, por acreditar no meu trabalho e, principalmente, por estar sempre presente e disponível em todos os momentos da realização desta dissertação.

A German Lorca, pela generosidade, pelas entrevistas, pela colaboração.

À todos aqueles da empresa Photoimagem 5, que em algum momento colaboraram com a minha pesquisa.

Ao Prof. Atílio José Avancini, da Faculdade de Jornalismo da ECA-USP, pela conversa sobre Vincenzo Pastore.

Ao Grupo de Estudos do Centro de Pesquisa em Arte e Fotografia do Depto. de Artes Plásticas a ECA-USP, em especial a Carolina Coelho e Heloisa Espada, que compartilharam as suas pesquisas comigo e, Laura Cury, pela ajuda na versão do resumo desta dissertação para o inglês.

Ao Jose Luiz Pedro, presidente do Foto-Cine Clube Bandeirante, pela colaboração, disponibilizando para consulta os boletins da agremiação.

Ao Sr. Renato Magalhães Gouveia e equipe da Biblioteca do Museu de Arte de São Paulo - MASP, pela colaboração e agilidade no cumprimento das solicitações necessárias para a realização de minha pesquisa.

À Sra. Tamiko Shimada e equipe da Biblioteca Mario de Andrade, pela presteza no atendimento e na microfilmagem das revistas Life e Íris.

A Equipe do acervo do Museu de Arte Moderna de São Paulo - MAM/SP, sempre eficaz no atendimento.

E a todos aqueles que tornaram este trabalho possível. 


\section{Sumário}

Introdução ......................................................................................................... 1

Capítulo 1: A Genealogia do pseudoflagrante........................................ 27

O pseudoflagrante em Menina na Chuva: base para uma genealogia .................................. 27

A vontade de registrar o movimento e a instantaneidade na arte ...................................... 31

A imobilidade da pose do retrato fotográfico e a espontaneidade do flagrante........................54

A instantaneidade e o pseudoflagrante nos primórdios da fotografia: do registro de objetos à

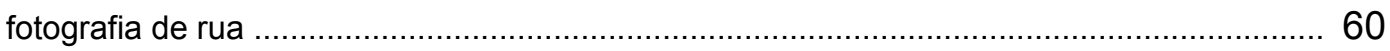

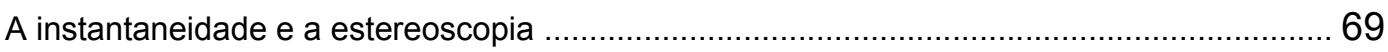

Anos 1880 a 1890: o impulso à captação do instante pela introdução no mercado das câmaras

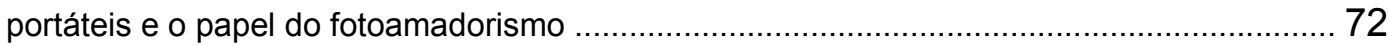

Os primórdios do fotojornalismo na Europa e nos Estados Unidos ........................................ 75

As guerras na Europa e nos Estados Unidos e o desenvolvimento do fotojornalismo no século

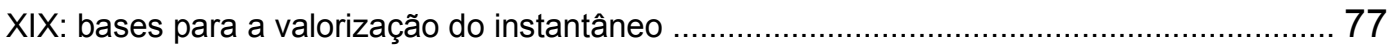

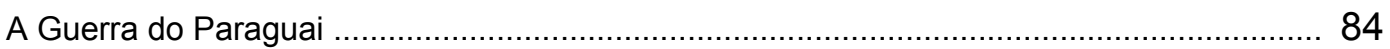

Considerações sobre a fotografia de rua no Brasil: Vincenzo Pastore ................................. 89

Capítulo 2: Menina na Chuva - momento decisivo ou encenação? ......... 98

O flagrante e o pseudoflagrante no fotojonralismo do século XX na Europa e Estados Unidos ............ 99

O fotojornalismo e o momento decisivo de Henri Cartier-Bresson .............................................. . 111

German Lorca e Henri Cartier Bresson: aproximações possíveis entre Menina na Chuva e Atrás da

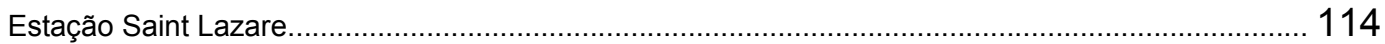

A fotografia moderna no Brasil nos anos 1950: fotoamadorismo e fotojornalismo ............................. 115

Jean Manzon (O Cruzeiro), Henri Cartier-Bresson (Life) e German Lorca (Foto-Cine Clube

Bandeirante): a formação de um repertório visual .................................................... 127

Breve reflexão sobre German Lorca e o debate internacional com a fotografia nos anos 1950 no Foto -

Cine Clube Bandeirante .................................................................................................... 146

As aproximações possíveis entre Menina na Chuva e Atrás da Estação Saint Lazare ....................... 153

Capítulo 3 - O flagrante, o pseudoflagrante e a composição na fotografia de German Lorca ............................................................................ 159

Considerações Finais...................................................................... 179

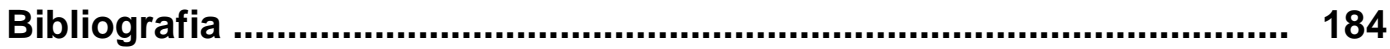




\section{Introdução}

Creio que é importante trazer à luz a raiz (ou raizes) do meu tema de mestrado que reflete sobre o flagrante, o pseudoflagrante e a composição na fotografia de German Lorca, tema desencadeado pela análise da fotografia Menina na Chuva, de German Lorca, realizada no início da década de 1950, para um concurso do Foto-Cine Clube Bandeirante.

A fotografia em questão parece um flagrante e sempre foi vista como tal, embora, segundo depoimento do fotógrafo, ele tenha pedido para sua sobrinha, Eunice, então com sete anos, encenar a foto.

Qual o limite entre o flagrante e uma encenação? Como um fotógrafo realiza um flagrante? O que é um flagrante, dentro da tradição da fotografia?

Essa última questão foi a que primeiro me mobilizou. Assim, logo fui tentar descobrir o que era, de fato, um flagrante ${ }^{1}$.

\section{§§§§§}

Às vezes me pergunto por que escolhi estudar determinado escopo da produção de um fotógrafo e não de um pintor, por exemplo.

Venho de uma família em que a fotografia é um hobby muito praticado. Meu padrinho, o tio Abel, que faleceu quando eu tinha onze anos, costumava

\footnotetext{
${ }^{1}$ Existem diferentes terminologias, intercambiáveis, utilizadas no decorrer da história da fotografia para significar um "flagrante", ou seja, o ato de flagrar uma cena: instantâneo, snapshot, candid photography, candid camera, instantaneous photography e momento decisivo, por exemplo. Por um lado, considero que essas terminologias não sejam exatamente sinônimas, pois acarretam pequenas especificidades em seu significado de acordo com o contexto em que são abordadas. Por exemplo, a terminologia candid photography foi cunhada a partir da fotografia realizada pelo fotógrafo alemão Erich Salomon, na década de 1920. Assim como momento decisivo, foi um termo difundido, principalmente, graças a sua utilização por Henri Cartier Bresson, o que não impede, por exemplo, que o fotógrafo francês tenha sido considerado um mestre do snapshot. Por outro, todas essas terminologias têm em comum o ato de flagrar. Sob essa perspectiva, equivalem ao termo "flagrante" e, portanto, poderão aparecer durante esta dissertação com esse sentido.
} 
registrar a paisagem de sua cidade natal, São Pedro, localizada no interior do estado de São Paulo. E também as festas de aniversário, inclusive as minhas. Meus primos, não só os filhos do tio Abel, estão sempre com a câmara nas mãos em festividades familiares.

Minha avó por parte de mãe, a Vó Rosa, enquanto viveu, apesar de não fotografar, nunca deixou de colecionar os retratos dos sete filhos, vinte e um netos e dezenove bisnetos, em pequenos álbuns que ela mesma organizava.

Continuo vivenciando essa prática da fotografia em minha família, seja pelo testemunho de sua realização em festas, em pequenas reuniões e em situações cotidianas de diversas fases de nossas vidas por gerações e gerações, ou pelo hábito que quase todos temos de colecioná-la. A fotografia é também uma base de troca entre nós.

Em casa, embora meu pai, Edson Ribeiro, seja um apreciador de fotografias, o hábito e gosto de fotografar, assim como de colecionar, vem por parte de minha mãe, Rosa Mir.

Artista plástica e fotógrafa, desde a infância que vejo minha mãe com a câmera fotográfica Minolta ou Olympus na mão realizando ensaios artísticos embora hoje em dia ela use também uma Cannon Digital - mesmo quando o assunto são os momentos cotidianos da família. As fotografias de eventos familiares realizadas pela minha mãe sempre extrapolaram a idéia de simples registro documental.

Entre os ensaios fotográficos dela, alguns protagonizados por mim e pelos meus irmãos, houve um que me marcou bastante. A série de dez 
fotografias $^{2}$, da qual fui modelo, que ela realizou para um concurso sobre “Ecologia”, promovido pela Escola de Fotografia Imagem e Ação em 1982, com a qual foi premiada [llustração I].
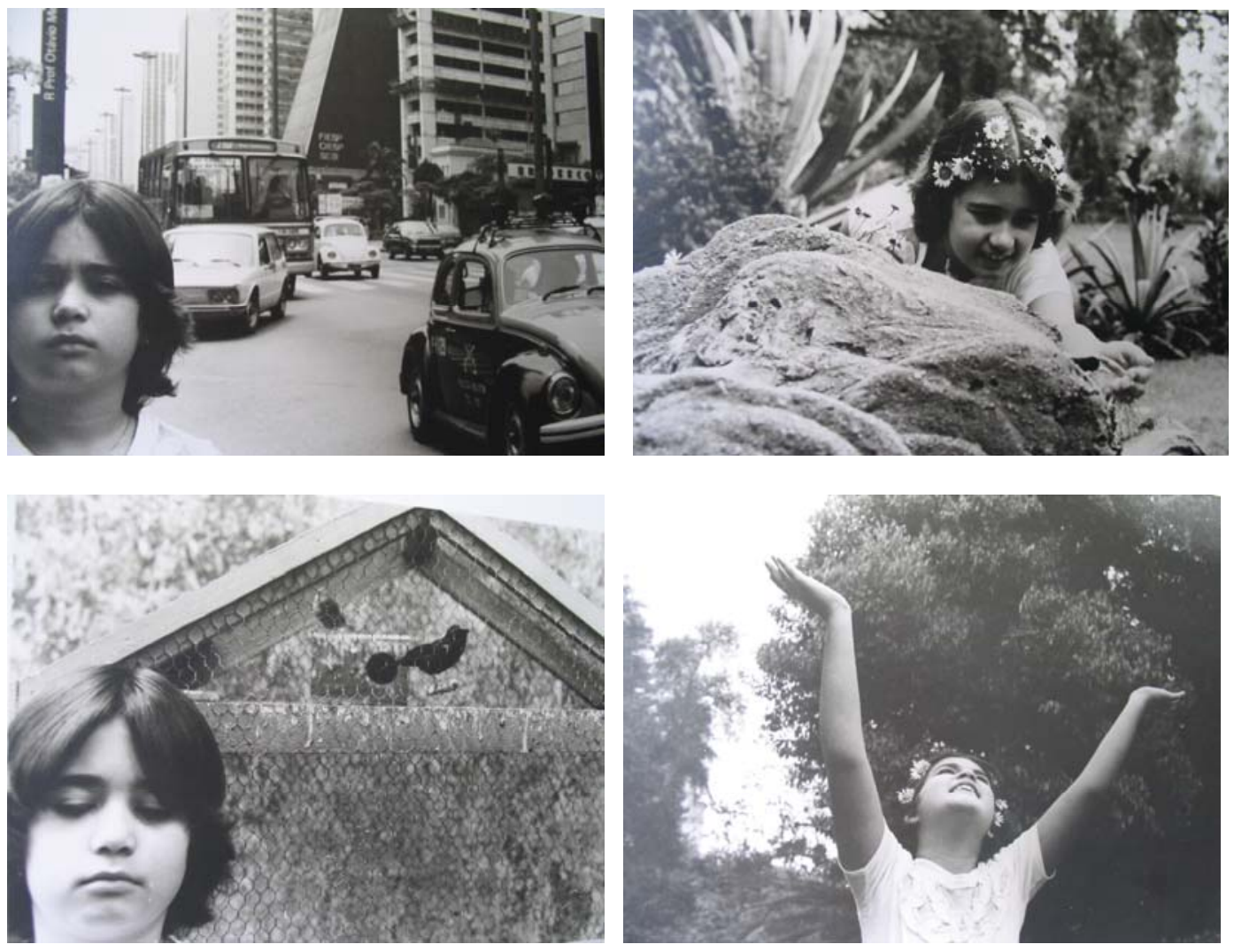

Ilustração I: Rosa Mir. Da série Ecologia, 1982.

Em uma aproximação possível com o Lorca, eu fui uma espécie de Menina na Chuva para minha mãe, assim como a Eunice foi para Lorca.

Mesmo com toda essa bagagem familiar, o interesse pela fotografia veio para mim muito tarde.

${ }^{2} \mathrm{O}$ ensaio foi realizado com uma câmara Minolta $(45 \mathrm{~mm})$ e teleobjetiva da mesma marca $(135 \mathrm{~mm}, 2.8)$. O filme utilizado foi o Kodak 125 ASA P\&B e o papel, o Ektalure $\mathrm{H}$. O trabalho foi revelado e ampliado manualmente pela fotógrafa. 
Com raras exceções, sempre fui péssima fotógrafa. Não existe para mim constrangimento maior do que ter de bater uma fotografia. Além disso, tenho dificuldade em me aproximar do universo de fotografias da minha família. Não raro, essas imagens me causam uma comoção quase insuportável.

Acredito que, em um primeiro momento, levei essa relação de distanciamento da fotografia para a vida profissional. Curiosamente, na minha trajetória como produtora cultural, entre 1996 e 2000, antes de abraçar o exercício da crítica de arte, produzi ou montei diversas exposições fotográficas sem me aproximar verdadeiramente do conjunto de fotografias nelas contidas. É como se existisse uma barreira.

Até que chegou a oportunidade do exercício da crítica no final de 2000. Deparei-me com a fotografia logo no meu segundo texto, em 2001, quando fui designada para escrever sobre o trabalho da fotógrafa paulistana Domitilia Coelho. Depois dessa "estréia", coincidentemente ou não, tive mais textos sobre produções de fotógrafos para escrever.

Em 2002, tomando como base minha vivência profissional na crítica de arte até então - observando que a metrópole paulistana era frequentemente retratada na fotografia contemporânea -, decidi me inscrever no Mestrado da Escola de Comunicações e Artes da USP visando um aprofundamento no assunto: apresentei como proposta estudar a iconografia de São Paulo e as mudanças desse registro histórico e documental por meio da manipulação da imagem, principalmente dentro da produção jovem.

No ano seguinte, uma vez aluna de pós-graduação, o Prof. Dr. Tadeu Chiarelli, meu orientador, sugeriu o redimensionamento do meu projeto: o estudo da iconografia fotográfica paulistana em três tempos - Militão Augusto 
de Azevedo (São Paulo Antiga), German Lorca (São Paulo Moderna) e Cássio Vasconcellos (São Paulo Contemporânea).

Aceitei e me senti atraída pela possibilidade de iniciar a pesquisa pelo meio, isto é, pela produção de German Lorca.

Fotógrafo paulistano nascido em 1922, no bairro do Brás, German Lorca foi um dos pioneiros da fotografia moderna brasileira, juntamente com nomes como Chico Albuquerque, Geraldo de Barros e Thomaz Farkas. Acredito que foi a escassez de material sobre esse fotógrafo que chamou a minha atenção, em um primeiro momento. Tratei de agendar uma visita ao Acervo do Museu de Arte Moderna de São Paulo (MAM-SP), que possui a maior coleção pública de fotografias de German Lorca até hoje: 50 no total. Alguns meses depois, em 22 de outubro de 2003, contatei-o para uma entrevista a fim de começar a estabelecer um panorama sobre a sua trajetória, partindo de como teria sido o seu início na fotografia.

De origem humilde, filho de imigrantes espanhóis, terceiro entre oito irmãos, German Lorca forma-se em Ciências Contábeis pelo Liceu Acadêmico São Paulo, em 1940. Em 1948 começa oficialmente ${ }^{3}$ a sua carreira fotográfica, como amador, quando ingressa no Foto-Cine Clube Bandeirante ${ }^{4}$.

Lorca sai fotógrafo profissional do Bandeirante em 1952, ano em que abre o seu próprio estúdio, o G. Lorca Foto Studio ${ }^{5}$, localizado à Avenida

\footnotetext{
${ }^{3} \mathrm{Em}$ depoimento concedido à autora em 22 de outubro de 2003, German Lorca conta que começou a fotografar entre 1946 e 1947, época em que comprou uma câmara Welti de $35 \mathrm{~mm}$, antes de ingressar no Foto-Cine Clube Bandeirante. Nesse período, Lorca costumava fazer fotos de seus parentes para álbuns de família. Notando o interesse de Lorca pela fotografia, seu tio, Manuel Rodrigues Ferreira, atualmente com 90 anos, escritor, sertanista e fotógrafo, incentivou-o a aprender a técnica fotográfica. A partir daí, Lorca procuraria o Bandeirante.

${ }^{4}$ Esta agremiação, voltada à fotografia amadora, importante marco na difusão da fotografia moderna brasileira, foi fundada em 28 de abril de 1939, com o nome de Foto Clube Bandeirante. Em 1945, o Clube amplia suas atividades, com a criação do Depto. de Cinema e altera seu estatuto, passando a ser denominado Foto-Cine Clube Bandeirante. German Lorca ingressou no Bandeirante sob a inscrição de $n^{\circ} 499$, conforme consta do boletim $n^{\circ}$. 21 - Ano II, de janeiro de 1948, p. 15.

${ }^{5} \mathrm{O}$ estúdio era direcionado "à fotografia técnica industrial e comercial - reportagens em geral, álbuns para crianças e casamentos", conforme anúncio no Boletim do Foto-Cine Clube Bandeirante n. 74 de 1952.
} 
Ipiranga, no centro de São Paulo. No mesmo ano, realiza sua primeira individual no Museu de Arte Moderna de São Paulo.

Dois anos mais tarde, Lorca abre o estúdio Lorca Fotógrafos Ltda., à Avenida Lins de Vasconcelos, no bairro do Cambuci, cuja atividade principal era a fotografia publicitária. Em $1988^{6}$, o fotógrafo fecha esse estúdio para trabalhar na empresa Photoimagem 5, no bairro de Vila Mariana, dos seus filhos Frederico e José Henrique Lorca, especializada em fotografia documental e publicitária. Diretor dessa empresa até 2003, atualmente Lorca dedica-se a projetos pessoais. Em 60 anos de carreira, o fotógrafo possui ampla e variada produção que abrange desde fotografias de rua, até retratos, paisagens e arquitetura, nus, naturezas-mortas, fotografias publicitárias e reportagens ${ }^{7}$.

De posse desse histórico abrangente, procurei analisar como essa produção eclética se situava dentro da trajetória de German Lorca, isto é, que importância ela tinha para o seu desenvolvimento como fotógrafo e com quais categorias de fotografias ele teria encontrado reconhecimento profissional.

Estudando sua atividade no Foto-Cine Clube Bandeirante - por meio dos boletins da agremiação -, entendi que esse ecletismo foi fruto, a princípio, de

\footnotetext{
${ }^{6}$ Em 1966 German Lorca transfere o estúdio Lorca Fotógrafos para a Rua Gregório Serrão, no bairro de Vila Mariana, encerrando as atividades desse estúdio em 1988. Contudo, a mesma casa que abrigava o Lorca Fotógrafos se tornaria sede da empresa Photoimagem 5.

${ }^{7}$ German Lorca permitiu que a autora tivesse acesso ao local no qual está armazenado seu arquivo pessoal, composto por ampliações e slides. Desse modo, foi possível ter a dimensão do ecletismo da produção do fotógrafo. $O$ arquivo de fotos em papel está dividido em 45 caixas de papelão, revestidas com papel kraft e identificadas por títulos gerais - os quais podem ser modificados de acordo com a reorganização do conteúdo das caixas por Lorca -, como: "Cavalos"; "Instrumentos"; "Barcos"; "Árvores"; “Arquitetura”; "Chuva e folhagem”; "Águas, janelas e paisagens"; "Crianças"; "Propaganda"; "Ver o peso"; "Nova York"; "Fotos Autor"; "Portugal, Espanha"; "Nus, trens"; "Composição"; "Fotos cores antigas"; "Retratos"; "Fotos São Paulo"; "Fotografias com pessoas", entre outros. Não foi possível verificar o conteúdo de todas as caixas, apenas de parte delas, atendendo a determinação de German Lorca de manusear as fotografias do arquivo apenas com seu acompanhamento (o fotógrafo raramente dispunha do tempo requerido para essa tarefa). Todas as caixas possuem duas tampas internas de papel filtro para proteger as fotografias e encontram-se armazenadas em uma estante de madeira com 7 divisões. A estante com as caixas localiza-se em uma sala cuja climatização foi instalada em julho de 2004. Os slides vistos estão agrupados em folhas plásticas com capacidade para 20 slides cada uma, em uma pasta contendo por volta de 200 folhas. A pasta está guardada na mesma estante das caixas. As fotografias e slides observados estão em bom estado de conservação.
} 
sua profícua atuação em salões, concursos e seminários, ao longo dos quatro anos que lá permaneceu realizando seu aprendizado fotográfico ${ }^{8}$.

Contudo, o ecletismo de Lorca abarcaria também a realização de flagrantes para pequenas reportagens sobre eventos do Foto-Cine Clube Bandeirante, como alguns daqueles que ilustram $012^{\circ}$ Aniversário da entidade ${ }^{9}$

Talvez tenham sido essas incursões pela reportagem que direcionaram o rumo inicial de sua atuação profissional, lembrando que uma das ofertas de seu primeiro estúdio era a reportagem: Lorca considera, por exemplo, que de fato se lançou profissionalmente como fotógrafo oficial do IV Centenário de São Paulo, em 1954, quando realizou uma reportagem fotográfica desse evento para a Revista Abril $^{10}$.

Porém, como já foi citado, a partir da abertura do seu segundo estúdio, Lorca se decidiria pela fotografia publicitária. De acordo com o fotógrafo, sua opção pela fotografia publicitária deveu-se ao fato dessa atividade proporcionar um "ganho financeiro maior ${ }^{11 "}$ - uma vez que ele já era casado, tinha um filho e aguardava o nascimento do segundo -, e que lhe possibilitava também sustentar a realização de seus ensaios autorais.

Continuando o meu estudo, notei que essa opção profissional pela fotografia publicitária trouxe êxito a Lorca, que ganhou diversos prêmios por

\footnotetext{
${ }^{8}$ A atuação de Lorca se comprova por meio dos anúncios, em diversos números dos boletins do Foto-Cine Clube Bandeirante, sobre os resultados dos vários concursos e salões promovidos por essa agremiação, em muitos dos quais o fotógrafo participou com fotografias de diferentes categorias tais como fotografias de rua, de paisagens, de arquitetura e naturezas-mortas. Nesses anúncios mencionam-se fotografias como "Irmã de Caridade", "Noturno Fluvial”, "Aproveitando a Sombra", "Cenas Quotidianas", "A Procura de Emprego", "Fim de Pescaria”, "Le Diables au Corps", "Pano", "Chuva na Janela", "Arquitetura", "Amigos", "Casa Velha", "Jarra e Copo", "Trópicos" e "Malandragem". Note-se que foi no Foto-Cine Clube Bandeirante que Lorca realizou fotos que se tornariam memoráveis como Menina na Chuva (1950), Homem na Chuva (1950) e Malandragem (1949), atualmente pertencentes ao Acervo do Museu de Arte Moderna de São Paulo (MAM-SP), embora as duas primeiras não sejam citadas nos boletins e sim no depoimento de Lorca concedido à autora em 15 de abril de 2004.

${ }^{9}$ Eduardo Salvatore e J. Agostineli também realizaram flagrantes para esse evento. Ver Boletim Ano VI, Maio de 1951.

${ }^{10}$ Depoimento concedido à autora em entrevista telefônica de 07 de julho de 2004 .

${ }^{11}$ Depoimento concedido à autora em 15 de abril de 2004 e reafirmado em entrevista telefônica em 07 de julho do mesmo ano.
} 
sua atuação nesse ramo $^{12}$. Ao mesmo tempo, se observava que, fora do âmbito do Foto-Cine Clube Bandeirante ${ }^{13}$, a presença de suas fotografias autorais enfraquecia no circuito de exposições, considerando que era mostrada em intervalos irregulares. Mas, ainda assim, a fotografia autoral de Lorca foi reconhecida no circuito de museus e galerias entre as décadas de 1950 e 1970.

O fotógrafo faz sua primeira individual em 1952 no Museu de Arte Moderna de São Paulo, intitulada "35 Fotografias G. Lorca", na qual mostra fotografias diversas ${ }^{14}$.

Segundo o artigo "Exposição G. Lorca", publicado em um boletim do Bandeirante:

Não foram trabalhos todos inéditos; antes teve a mostra caráter retrospectivo, reunindo o expositor provas executadas de 1948 para cá. Todavia, e talvez por isso mesmo, melhor ficamos conhecendo a evolução do artista no trato dos problemas estéticos do preto e branco $^{15}$.

\footnotetext{
${ }^{12}$ Mérito, fotos publicitárias em Miami, EUA (1961); Menção honrosa, fotos publicitárias em Miami, EUA (1962); Folha de Ouro, fotos publicitárias, Folha de S.Paulo (1963); Medalha de bronze, fotos publicitárias, Folha de S.Paulo (1965); Prêmio Colunistas, melhor campanha fotos publicitárias de caminhões, São Paulo (1985); Medalha de Prata, foto publicitária, Seafesp, São Paulo (1986); Prêmio Colunistas para o Nordeste, melhor campanha de fotos publicitárias do Banco do Brasil, 1989.

${ }^{13}$ Entre o circuito de salões nacionais e internacionais, dos quais German Lorca participou por meio do Foto-Cine Clube Bandeirante, próximo de sua saída do Bandeirante, entre os anos de 1951 e 1952, destacam-se: a coletiva que participou no Clube em 1951, e a exposição internacional referente ao concurso do prêmio Alejandro del Conte, em Buenos, Aires, no ano de 1952, no qual obteve a medalha de ouro.

${ }^{14}$ German Lorca apresentou as 35 fotografias divididas em quatro blocos: interiores (Vitrina, 1950, Cadeira, 1951, Volpi's Place, 1952), estúdio (retrato,1950, solarização,1950, Le Diable au corps, 1950, e nu, 1952), flashlight (casamento, 1952 e composição, 1952) e exteriores (a procura de emprego, 1948, estudo de movimento, 1948, terceira classe, 1949, Malandragem, 1949, carrossel, 1949, janela I, 1950, forma I, 1950, arquitetura, 1950, panejamento, 1950, reflexo, 1950, linhas, 1950, jornais, 1951, o vigário, 1951, sombra, 1951, sombra na cortina, 1951, estudo com menina, 1951, estudos em branco, 1951, formas II, 1951, textura I e II, ambas de 1951, janela II, III, IV e V, todas de 1951, tetos brancos, 1951 e formas III, 1952 . O folder não traz imagens, mas, entre as 35 fotografias estão fotografias que se tornariam emblemáticas na carreira de Lorca como Malandragem, Le Diables au Corps e Estudo com Menina, que segundo entrevista com German Lorca, trata-se da fotografia Menina na Chuva. Algumas datas divergem das oficias, como no caso de A Procura de emprego que aqui consta como 1948, mas que ingressou com a data de 1951 para a coleção do MAM, em 1999. Ao solicitar a Lorca para ver em seu acervo as fotografias que correspondem aos títulos constantes do folder, ele respondeu que muitas se perderam.

${ }^{15}$ Ver Boletim Ano VII n. 74, junho 1952, p. 30.
} 
Sobre o conjunto de obras apresentado, Geraldo de Barros comenta no folder da mostra:

(...) Partindo do trabalho bem cuidado, ele se realiza lenta mas seguramente. Abandona o tema social para cada vez mais se exprimir através de valores plásticos puros. A preocupação do assunto e o gosto pelo literário desaparecem, substituídos pelos ritmos e composições em branco e negro, uma vez adquirida a consciência plástica dos problemas de arranjo numa superfície.

Hoje, a objetiva não é mais obstáculo ao seu trabalho pois Lorca não depende exclusivamente dela para realizar suas fotografias - descobriu, afinal, em si mesmo, a liberdade, sentindo plenamente a necessidade da criação ${ }^{16}$.

Depois, será na década de 1960, mais precisamente no ano de 1966, que Lorca fará uma individual com fotografias autorais, exibindo-as na Galeria São Luiz, em São Paulo.

Mais tarde, nos anos 1970, Lorca participa de duas importantes exposições, uma individual e a outra coletiva. Em 1978, o fotógrafo, então com 56 anos, expõe no MASP, em comemoração a seus 30 anos de carreira, 180 fotografias "muitas delas premiadas aqui e nos Estados Unidos", segundo matéria no caderno "Artes", da Folha de São Paulo ${ }^{17}$. Ainda de acordo com a matéria:

No MASP Lorca mostra trabalhos executados em cores e em branco e preto, desde cenas cotidianas, até retratos, composições a lembrar pinturas abstratas e geométricas e documentação sobre o futuro Museu de Açúcar a ser implantado em Sertãozinho ${ }^{18}$.

\footnotetext{
${ }^{16}$ Idem, ibidem. Ver também folder da exposição "35 fotografias de G. Lorca", Museu de Arte Moderna de São Paulo, 1952.

${ }_{18}^{17}$ Ver "180 fotos de Lorca no MASP", Caderno de Artes, Folha de São Paulo, 25 de ago. de 1978.

${ }^{18}$ Idem, ibidem
} 
Entre as fotografias realizadas em preto e branco, German Lorca exibe no local, por exemplo, Só para Mulheres ${ }^{19}$ [llustração II], datada de 1954.

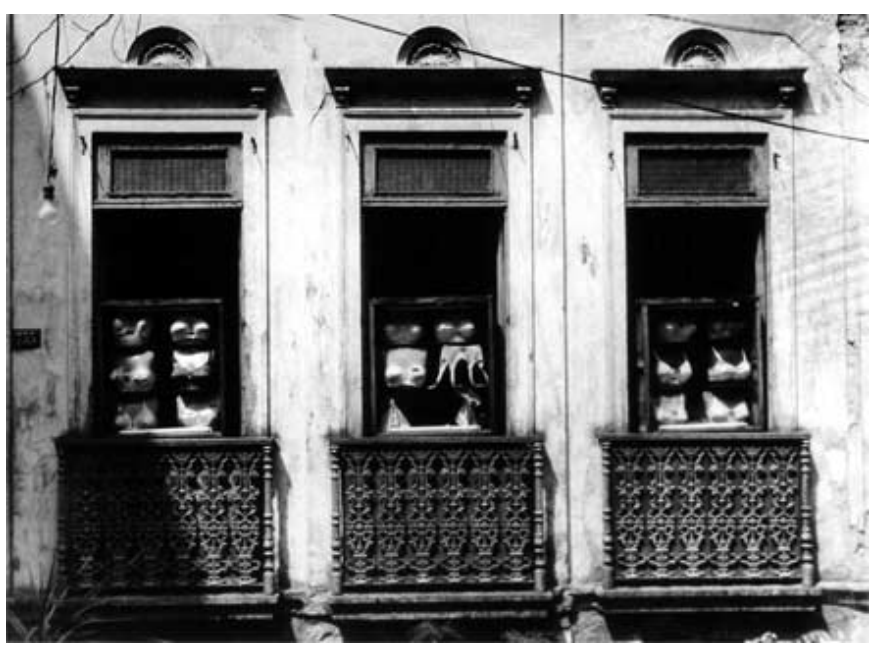

Ilustração II: German Lorca. Só para Mulheres, 1954. Acervo de German Lorca.

Em 1979, Lorca participa de uma coletiva no espaço Magazzini del Sale do prédio da Bienal de Veneza intitulada Venezia'79 - La fotografia, juntamente com Geraldo de Barros e outros fotógrafos, como o italiano Nino Migliori ${ }^{20}$.

Os anos 1970, quando Lorca participa dessas duas exposições, correspondem a um importante momento histórico que tem raíz em uma corrente que acontecia na Europa e Estados Unidos.

Segundo Joan Fontcuberta:

\footnotetext{
${ }^{19}$ Essa fotografia ilustra a matéria "180 fotos de Lorca no MASP", publicada na Folha de São Paulo (op. cit.). Não foi possível encontrar nenhum folder ou catálogo da exposição para verificar as demais fotografias, na Biblioteca do MASP. Tal fotografia passa a integrar o acervo da Coleção Pirelli Masp em novembro de 2005.

${ }^{20}$ Aqui se trata de um cruzamento de dados: no item "coletivas" do currículo de German Lorca publicado no catálogo II Bienal de Curitiba (1998), consta a exposição "La fotografia", Veneza, Itália, 1979. No catálogo da exposição Fotoformas - Geraldo de Barros (Munique: Prestel, 1999), lê-se em "group exhibitions": Venezia 1979/La fotografia, Veneza. Em pesquisa realizada na Internet encontrou-se o currículo do fotógrafo italiano Nino Migliori no qual figura o seguinte dado: "Nino Migliori, Venezia'79. La fotografia. Magazzini del Sale, La Biennale di Venezia. 17 giugno -16 settembre." Essa exposição não pode ter ocorrido durante uma Bienal de Veneza considerando que a última bienal que ocorreu no final dos anos 1970, nessa cidade, data de 1978. A Bienal de Veneza de 1978 não apresentou nenhum núcleo denominado La Fotografia, no espaço Magazzini del Sale, nem em qualquer outro pavilhão. Ver catálogo La Biennale di Venzia - Dalla Natura all'arte, dall'arte alla natura, 1978, 02 de julho a 15 de outubro.
} 
Tanto no âmbito dos Estados Unidos como na dos países Europeus mais avançados, a década dos setenta significou para a fotografia o início de sua dupla institucionalização como matéria acadêmica e museística. Pode-se afirmar que, anteriormente, a fotografia já havia recebido tratamento universitário e era colecionada em museus. Isso é certo, porém é partir desses anos que a sua implantação se popularizará nas estruturas canonizadoras do saber e da cultura ${ }^{21}$.

No Brasil, de acordo com Ricardo Mendes e Mônica Junqueira de Camargo:

Exposições e debates proliferam, em especial ocupando o espaço de escolas de fotografia, fora do circuito fotoclubístico predominante no momento anterior. Em agosto de 1971 a ENFOCO abre sua galeria, seguida mais tarde pela IMAGEM-AÇÃO ([1976]). Amplia-se o conjunto de locais disponíveis, mantendo-se ainda as mostras em lojas especializadas (...). É possível identificar um crescimento de eventos individuais em detrimento de coletivas, embora sem participação no mercado. Orientação que seria incentivada por promoções como o Movimento Fotogaleria, a partir de 1973, que encontra espaço na GALERIA BONFIGLIOLI. Extensão do empreendimento gerado a partir da galeria cooperativa PHOTOGALERIA, aberta no Rio de Janeiro naquele ano, o Movimento promove a discussão de questões como mercado de arte e direitos autorais $^{22}$.

Durante os anos 1970 haverá, ainda, um crescimento na imprensa especializada, com a propagação de revistas como a Revista de Fotografia

\footnotetext{
${ }^{21}$ Ver FONTCUBERTA, Joan. Fotografia (ed). Crisis de história. Barcelona: Actar, 2005, p. 7.

${ }^{22}$ CAMARGO, Mônica Junqueira de; MENDES, Ricardo. Fotografia; cultura e fotografia paulista no século XX. São

Paulo: Secretaria Municipal de Cultura, 1992. p. 104.
} 
(1971-1972), a Novidades Fotótica, Atualidades Cinótica, a Foto Mundo (1971 -1975) e a $\mathrm{Akopol}^{23}$.

Em paralelo a esse fenômeno, aumentará a freqüência de exposições de fotógrafos estrangeiros, fora do circuito fotoclubístico, que coincide com a reestruturação ou criação de novos museus:

(...)Agora, na nova sede, o MUSEU DE ARTE DE SÃO PAULO, retoma suas atividades, coordenadas por Cláudia Andujar. Tenta-se estabelecer uma política de aquisição de obras para o acervo, oferecem-se cursos, com a presença de GEORGE LOVE e CLÀUDIA.

A criação, em 1970, do MUSEU DA IMAGEM E DO SOM revela a preocupação com a memória audiovisual. A fotografia surge aqui pela sua potencialidade instrumental, embora uma política integrada não se consolide plenamente. Em 1980, é a vez de a PINACOTECA DO ESTADO abrir o GABINETE FOTOGRÁFICO, coordenado por Rubens Fernandes Jr. (Rio Claro, 1950), numa experiência que se estende por três anos. Ainda no período o MUSEU LASAR SEGALL (MLS) passa a realizar exposições fotográficas em "uma linha histórica/didática", evitando a valorização autoral. Certamente, dentre os diversos museus, a instituição representa o programa de ação mais bem sucedido no início dos anos 80 , integrando o setor de ensino ao trabalho com a comunidade ${ }^{24}$.

Nesse âmbito, destacam-se as exposições de Henri Cartier-Bresson, em 1970, e Brassai, em 1974, ambas no Museu de Arte Contemporânea (MAC), assim como de Ansel Adams e Bill Brandt, ambas realizadas no Museu de Arte de São Paulo (MASP), em 1974. Uma década mais tarde, o MASP volta a expor a produção de Henri Cartier-Bresson, desta vez em uma retrospectiva

\footnotetext{
${ }^{23}$ Idem, ibidem, p. 105 e 108. Além disso, renovam-se os periódicos mais antigos como a revista Íris, por exemplo. Segundo os autores, o mercado editorial voltado à publicação de ensaios começa de fato na segunda metade dos anos 1970 (p. 111).

${ }^{24}$ Idem, ibidem, p. 113.
} 
comemorativa aos 50 anos de carreira do fotógrafo, composta por 156 fotografias escolhidas pelo próprio.

A partir de 1993, quando se observa o aumento no número de exposições que German Lorca passa a participar com cenas de cotidiano captadas tanto no Estado de São Paulo como em Nova lorque, além de retratos e nus ${ }^{25}$, haverá uma inversão no foco profissional do fotógrafo: três anos depois, portanto em 1996, Lorca irá diminuir suas atividades como fotógrafo publicitário para enfatizar seus ensaios autorais.

Logo no ano seguinte (1997), três fotografias de German Lorca entram pela primeira vez para uma coleção pública - a Coleção Pirelli-MASP de Fotografia ${ }^{26}$, então em sua $7^{\text {a }}$ edição.

O texto de Rubens Fernandes Júnior para o catálogo dessa edição da exposição da Coleção, dá conta da atuação de Lorca como fotógrafo publicitário, mas que, ao mesmo tempo, exibe um trabalho autoral como fotógrafo-artista:

(...)German Lorca traz para a coleção um trabalho também realizado nos anos 1950 onde ainda predomina a forte influência dos fotoclubes. Apesar de ser um dos mais respeitados fotógrafos publicitários de São Paulo, suas primeiras referências foram as do Foto Clube Bandeirante: a geometrização, os fortes contrastes produzidos pelo p\&b,

\footnotetext{
${ }^{25}$ Individual no Museu de Arte de São Paulo - MASP (1993); Mês Internacional da Fotografia (1993 e 1995), São Paulo; I Bienal Internacional de Fotografia de Curitiba (1996); exposição da Coleção Pirelli-Masp de Fotografia (1997), São Paulo; II Bienal Internacional da Cidade de Curitiba (1998); Galeria Cultural do Citybank (1998), São Paulo; São Paulo por German Lorca (obras do acervo do MAM), MAM-SP, 2000; Galeria Kultur Fabric (2001), Koln, Alemanha; exposição do Acervo do MAM-SP (2001), MAM-SP; mostra em comemoração aos 450 anos de São Paulo, MAM-SP (2004); exposição 450 anos em 24 horas por 45 fotógrafos, no espaço cultural do Banco Nossa Caixa -SP (2004), e German Lorca - A fotografia como visão, no Museu de Arte Contemporânea da USP (2004). Em 2005, Lorca participa da coletiva Cinqüenta - 50 no Museu de Arte Moderna de São Paulo, e 10 Anos de um Novo Mam - Antologia do Acervo, no mesmo local, além da exposição da Coleção Pirelli-MASP, no Museu de Arte de São Paulo (MASP).

${ }^{26}$ As fotografias são as seguintes: "Apartamentos Populares, 1952", "Aeroportos", 1961, e "Pernas", 1970. Em novembro de 2005 , Lorca terá mais cinco fotografias de sua autoria agregadas à Coleção Pirelli-MASP, em sua $14^{\mathrm{a}}$ edição, desta vez a maioria produzida em 1954, privilegiando a temática urbana, entre as quais: "Desfile Goontex (1954)", obtida durante o IV Centenário de São Paulo; "Oca (1954)", realizada no Parque do Ibirapuera -SP e "Só para Mulheres (1954)", feita no Rio de Janeiro. Já em 1999, é o Museu de Arte Moderna de São Paulo que agrega 50 fotografias de Lorca a seu acervo. Em 2003, as 15 fotografias com as quais participou como homenageado do Prêmio Porto Seguro de Fotografias, são adquiridas para o acervo do Prêmio. Entre 2003 e 2004, as coleções do Banco Santos e do Instituto Itaú Cultural são ampliadas com fotografias de German Lorca.
} 
transgressão dos padrões clássicos de composição, a interferência do acaso, entre outros $^{27}$.

Nesse contexto, por um lado, a revalorização da fotografia autoral de German Lorca coincide com o momento em que ele começa a atuar menos como fotógrafo publicitário e mais como artista. Por outro lado, o fotógrafo nunca parou de fazer seus ensaios autorais nas brechas de sua atividade profissional, lembrando que a fotografia publicitária, além de subsidiar sua produção autoral pode tê-lo ajudado a divulgá-la, como ele próprio refletiu em uma de nossas conversas ${ }^{28}$.

Nesse ponto, cada vez mais eu me interessava em compreender a trajetória de Lorca como fotógrafo autoral, que, como pude perceber, enfrentaria "altos e baixos" talvez, por sua opção profissional pela fotografia publicitária.

\section{$\S \S \S \S$}

Esse caminho trilhado durante os anos de 2003 e 2004, pesquisando a produção do Lorca seja no MAM, nas visitas ao seu estúdio ou no Foto-Cine Clube Bandeirante, me levou a propor ao meu orientador a focar minha pesquisa somente nesse fotógrafo.

Proposta aceita, qual viés tinha mais me interessado para estudar na ampla produção de Lorca?

Interessei-me pelo conjunto de suas fotografias de rua e de paisagens urbanas de São Paulo (sempre considerando que minha motivação inicial de

\footnotetext{
${ }^{27}$ Ver Catálogo da Coleção Pirelli-MASP de fotografia $-7^{\text {a }}$ edição, 1997. Na verdade, entre as três fotografias que passam a compor o acervo, citadas na nota de rodapé de número 26 , apenas uma é da década de 1950 , sendo as outras duas das décadas de 1960 e 1970, respectivamente.

${ }^{28}$ Aqui me refiro a uma entrevista por telefone realizada em 07 de julho de 2004.
} 
estudo, acima de tudo, era a iconografia da fotografia paulistana), tanto as que eu havia visto no Acervo do MAM como no estúdio do fotógrafo. Entre essas, como mencionei anteriormente, me atraiu em especial a fotografia Menina na Chuva. A partir dela, começou a ficar claro para mim que meu objeto de estudo seria apenas as fotografias de rua de Lorca.

Assim, minha idéia inicial era estudar 25 fotografias de rua de sua autoria, compreendidas entre 1948 e 2004. Mas no decorrer do trabalho, isso mudou. Voltei meu olhar para a produção moderna de Lorca, realizada entre o final dos anos 1940 e início da década de 1950, período em que o fotógrafo atuou no Foto-Cine Clube Bandeirante. Essa produção se tornaria o foco de minha pesquisa: tive certeza de que, nas cenas de cotidiano de Lorca, flagradas ou não, eu encontraria as respostas às minhas perguntas, inclusive com relação à revalorização de sua obra.

\section{§§§§§}

Meu primeiro contato com a fotografia Menina na Chuva foi no acervo do Museu de Arte Moderna de São Paulo (MAM-SP), mas foi quando pude revê-la junto com Lorca, em seu estúdio, que fiquei realmente intrigada. Lorca, enquanto mostrava um conjunto de fotografias - entre as quais estava Menina na Chuva -, as classificava como do tipo "acontece" (flagrantes) e "faz acontecer" (fotografias posadas), referindo-se ao lema que criara anos antes "A fotografia acontece para o fotógrafo e ele a faz acontecer ${ }^{29 "}$.

\footnotetext{
${ }^{29} \mathrm{O}$ lema de Lorca foi eternizado em um anúncio da câmara Leica (“my point of view'), publicado na Revista Fotosite $\mathrm{n}^{\circ}$. 2 , ano I - out/nov 2004. Segundo conversa telefônica realizada em janeiro de 2006, entre a autora e Luis Marinho - da empresa Marinho Comércio Ltda, representante da câmara Leica no Brasil -, o anúncio foi realizado em 2004, um mês antes da publicação da revista. A imagem utilizada no anúncio é um auto-retrato de German Lorca, datado dos anos
} 
Para minha surpresa, Menina na Chuva foi encaixada, pelo artista, no segundo grupo. Como aquela fotografia, que parecia ser tão espontânea, poderia não ser um flagrante?

Enviei um e-mail para Lorca, aos cuidados de Angella Souza, então sua secretária, para me certificar da classificação. Recebi a seguinte resposta:

[03 de dezembro de 2003]

Bom Daniela...responderei os três e-mail's nesse mesmo, o.k. ?! Primeiramente, a fotografia Menina na Chuva o Sr. Lorca realmente fez acontecer... parece um flagrante, mas não é (...).

Minha intriga aumentou. Em entrevista realizada pessoalmente com Lorca no ano seguinte ${ }^{30}$, ele afirmou que se tratava de uma fotografia realizada com sua sobrinha, Eunice, filha de sua irmã e vizinha, para participar do concurso "Dias de Chuva", do Foto-Cine Clube Bandeirante, tema que discuto ao longo desta dissertação.

Nesse momento eu ainda estava em dúvida se estudaria somente as fotografias de rua ou também as paisagens urbanas de Lorca, e isto se refletiu em um dos meus primeiros trabalhos precursores do primeiro capítulo, denominado A fotografia de São Paulo por German Lorca em três eixos fundamentais: o flagrante, a pose e a paisagem ${ }^{31}$. Nesse trabalho, eu seguia o raciocínio de que Menina na Chuva era uma fotografia que transitava entre o flagrante e a pose.

1950. Ainda de acordo com Marinho, foi o próprio Lorca quem sugeriu a inserção de seu lema "A fotografia acontece para o fotógrafo e ele a faz acontecer" na imagem.

${ }^{30}$ Entrevista realizada em 15 de abril de 2004.

${ }^{31}$ Esse trabalho foi realizado como "projeto final do curso" para a disciplina $O$ artista brasileiro e a fotografia: a prática da apropriação no século XX, ministrada pelo Prof. Dr. Domingos Tadeu Chiarelli, na Pós-Graduação da Escola de Comunicações e Artes da USP ao longo do segundo semestre de 2003. 
$\mathrm{Na}$ discussão desse texto com o meu orientador é que concluí que eu estava diante de um falso flagrante e passei a denominar o fato de pseudoflagrante a fim de compreender e estudar a questão.

Mas, o fato é que havia um flagrante - o do pulo - e, também, uma pose, uma vez que a fotografia foi encenada.

Essa idéia com relação ao flagrante do pulo e a pose da menina, eu levei para o meu Exame de Qualificação, realizado em 23 de novembro de $2004^{32}$, que foi questionada pela banca examinadora: Menina na Chuva era ou não um flagrante? Sem apresentar uma resposta eficiente naquele momento, essa pergunta passaria me acompanhar a partir daí.

Voltei então a tentar buscar a razão de minha intriga específica com Menina na Chuva. Por que partir dessa fotografia, se eu sabia que ela não era o único pseudoflagrante de Lorca?

Lorca faz uso corrente desse recurso em sua produção: o pseudoflagrante pode ser observado em fotografias como Malandragem (1949) - dois homens que estavam em um bar encenam o fato, a pedido de Lorca, para a realização dessa fotografia -, ou Homem na Chuva (1950), na qual toma como modelo o seu irmão, por exemplo.

Talvez essa inquietação se deva à relação direta que estabeleci entre Menina na Chuva e o universo do "momento decisivo", defendida pelo fotógrafo francês Henri Cartier-Bresson. Especialmente depois que redescobri a fotografia Atrás da Estação Saint-Lazare, realizada pelo fotógrafo francês em

\footnotetext{
${ }^{32}$ No meu Exame de Qualificação, o Prof. Rubens Fernandes Júnior levantou a possibilidade de que a minha pesquisa estudasse as cenas de cotidiano de German Lorca em contrapartida com as suas fotografias publicitárias. No entanto, apesar da inquestionável relevância da sugestão, concluí, no andamento de minha pesquisa pós-qualificação, que o meu interesse residia, cada vez mais, em entender a prática do flagrante e de seu falseamento nas fotografias autorais de Lorca. Assim foi se tornando clara para mim a definição da abrangência de meu trabalho: as cenas de cotidiano que Lorca realizou durante a sua permanência no Foto-Cine Clube Bandeirante.
} 
1932, que só veio a público anos mais tarde, em 1947, na edição de 17 de março da revista norte-americana Life ${ }^{33}$.

Quando Lorca me disse, em entrevista, que não teve nenhum contato com a obra de Cartier-Bresson, em 1950, ano em que realizou Menina na Chuva e que era associado do Bandeirante, estranhei o fato, embora tenha respeitado seu depoimento ${ }^{34}$.

Esse fator me levou a pesquisar como Lorca, um fotógrafo de condição social humilde, e que, portanto, não poderia ter viajado para o exterior, teria tido acesso, na década de 1950, ao universo de um dos ícones da fotografia internacional - Henri Cartier-Bresson.

Minha primeira hipótese foi que ele teria encontrado essa referência, direta ou indiretamente, dentro ou por meio do Foto-Cine Clube Bandeirante: tanto na Biblioteca do Clube como em artigos publicados nos "FCB Boletins ${ }^{35 ",}$ nas discussões em seminários ou salões promovidos pela agremiação.

Por exemplo, na biblioteca do Bandeirante, foi localizado um livreto chamado All about the right moment in action photography, de autoria de Alex Strasser $^{36}$ : isso pode significar que questões sobre a obtenção de um instantâneo (the right moment) integravam os assuntos abordados didaticamente pela agremiação, como será visto no capítulo 2 .

\footnotetext{
${ }^{33}$ Atrás da Estação Saint-Lazare é uma das fotografias publicadas em 1952 no livro O momento decisivo (Images a la sauvette - l'instant decisif), de Henri-Cartier Bresson.

${ }^{34} \mathrm{Em}$ depoimento concedido à autora em 15 de abril de 2004, Lorca contou que: "O Cartier-Bresson não estava em foco no Foto-Clube Bandeirante, enquanto estive lá [1948-1952]. Eu não me lembro de ter ouvido falar de CartierBresson no Foto-Clube. O que existia eram fotos de fotoclubes estrangeiros, fotos clássicas, bem feitas. Depois do Foto-Clube é que eu fui saber de Cartier-Bresson". O fotógrafo iria afirmar publicamente que não tinha tido contato com o universo de Henri Cartier-Bresson quando realizou a fotografia Menina na Chuva, no debate "O estético e o social na trama fotográfica", que aconteceu em 04 de outubro de 2005, no Itaú Cultural, dentro do ciclo FotoPalavra, organizado pela editora CosacNaify. Esse debate contou com a participação da historiadora Helouise Costa e do fotojornalista Juca Martins, além de German Lorca.

${ }^{35}$ Os boletins receberam diferentes denominações ao longo de sua história. Por exemplo, considerando os anos de 1949 a 1952 encontraram-se as seguintes denominações: "Foto-Cine Clube Bandeirante Boletim" (de janeiro a julho de 1949); "FCB Boletim" (de agosto de 1949 a agosto de 1950); "Foto-Cine Boletim" (de setembro de 1950 até o final de 1952).

${ }^{36}$ Ver capítulo 2, nota de rodapé de número 98.
} 
Outra possibilidade seria o acesso de Lorca a revistas em acervos públicos que contivessem fotografias de Henri Cartier-Bresson.

$\mathrm{Na}$ verdade eu refletia sobre de que forma a obra de Cartier-Bresson circulava no Brasil e afetava a produção de nossos fotógrafos.

Encontrei em cinco exemplares da revista Life do final da década de 1940 e meados dos anos 1950 - entre os duzentos vistos na Biblioteca Municipal Mário de Andrade $(\mathrm{SP})^{37}$ — , reportagens com fotografias realizadas por CartierBresson [Ilustração III].
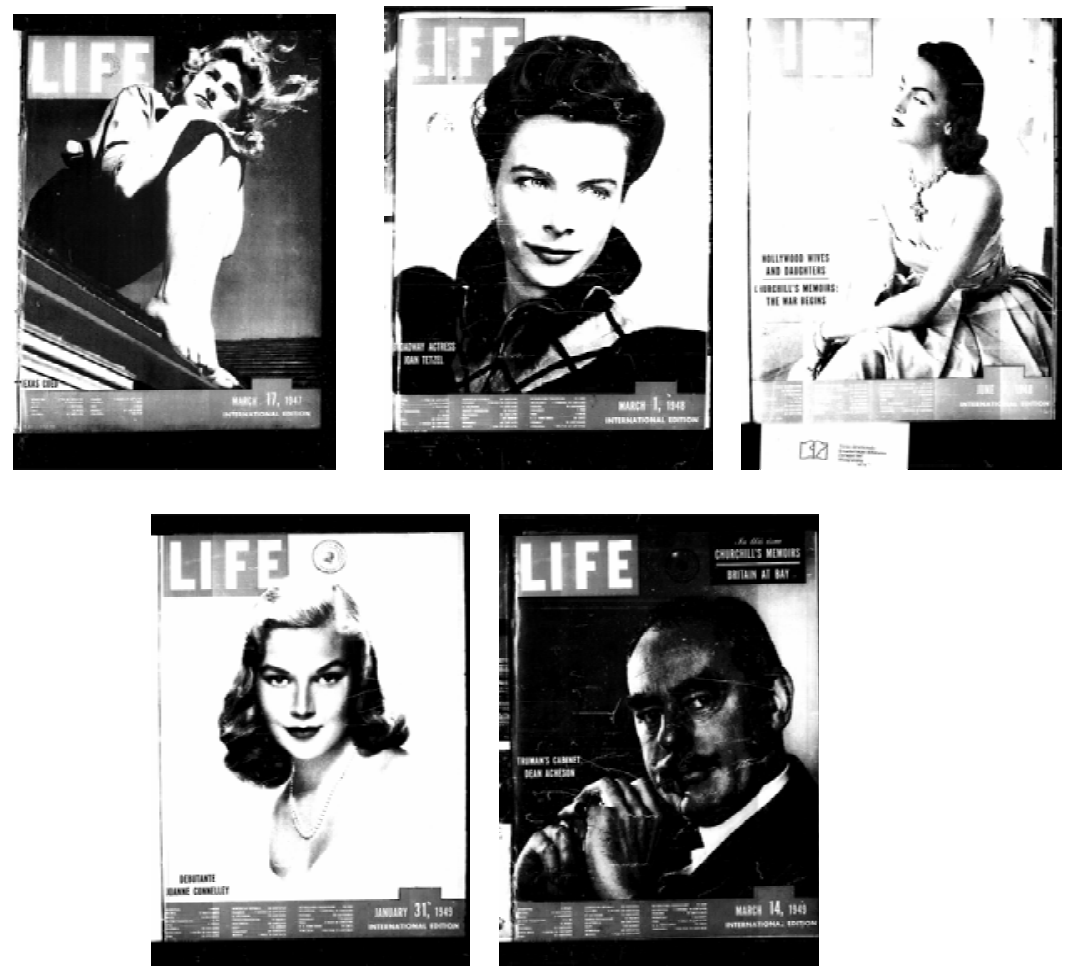

Ilustração III: Capas das edições da Revista Life International em que foram encontradas fotorreportagens de Henri Cartier-Bresson. Acervo da Biblioteca Mário de Andrade

\footnotetext{
${ }^{37}$ Foram verificadas na Biblioteca Municipal Mário de Andrade 201 edições da revista Life (Chicago e International), para localizar reportagens fotografadas por Henri Cartier-Bresson. Essas edições são datadas de 1940 a 1943; 1946 a 1949 e 1951. Dentro desse conjunto, foram observadas fotografias de Henri Cartier-Bresson nas seguintes edições: 17 de março de 1947; 31 de janeiro de 1949 (Photographic essays: A Last Look at Peiping); 14 de março de 1949 (matéria de James Burke com fotos de Cartier-Bresson), $\mathrm{n}^{\circ} .7$ de junho de 1948 e $\mathrm{n}^{\circ} .01$ de março de 1948 (Margaret BourkeWhite e Cartier-Bresson). Não foram encontradas as seqüências completas de cada ano das revistas observadas. As edições estão divididas em volumes em mau estado de conservação.
} 
Além disso, a pesquisadora Heloísa Espada Rodrigues Lima - que em breve apresentará sua dissertação de mestrado sobre a produção fotográfica de Geraldo de Barros -, na sua pesquisa em exemplares da Revista Íris do ano de 1947, localizou e compartilhou comigo, dados sobre uma exposição fotográfica de conteúdo internacional.

A estudiosa encontrou um número especial dessa revista ${ }^{38}$, dedicado a homenagear os Estados Unidos, que traz um encarte sobre a exposição didática de fotografia organizada pelo Museu de Arte Moderna de Nova lorque (MoMA -NY), que foi realizada na Biblioteca Mário de Andrade em julho de 1947. Tal exposição - patrocinada pelo Foto-Cine Clube Bandeirante ${ }^{39}$, juntamente com a União Cultural Brasil-Estados Unidos e com a Revista Íris apresentava fotografias de autoria de fotógrafos célebres, norte-americanos e europeus, entre eles, Henri Cartier-Bresson.

Essa exposição aconteceu um ano antes da entrada de Lorca no FotoCine Clube Bandeirante, é fato, mas demonstra que no final da década de 1940, em São Paulo, já se formava um debate em torno da fotografia internacional.

Todos esses dados me ajudariam a concluir que o contato de Lorca com os parâmetros praticados por Cartier-Bresson seria fruto das atividades promovidas pelo Foto-Cine Clube Banderiante das quais participaria, mesmo que pudesse não ter consciência disso naquele momento ${ }^{40}$.

\footnotetext{
${ }^{38}$ Ver Revista Íris Ano I, no. 6 de junho de 1947.

${ }^{39}$ Nos Boletins do Bandeirante dos meses de julho e agosto de 1947, Ano II, se reproduzem palestras proferidas por bandeirantes por ocasião da exposição Fotografia Artística realizada pelo Museu de Arte Moderna de Nova lorque, na Biblioteca Mário de Andrade. No artigo do boletim de Agosto, o autor comenta sobre a participação de fotógrafos europeus, além dos norte-americanos.

${ }^{40}$ Mais tarde, eu iria entender que seria necessário estabelecer um panorama da cultura visual (termo que será definido no capítulo 2) no qual o fotógrafo estava inserido nas décadas de 1940 e 1950. Esse assunto será debatido ao longo do capítulo 2.
} 
Nesse ponto de questionamento, eu já tinha tomado como premissa a máxima de Lorca - A fotografia acontece para o fotógrafo e ele a faz acontecer-, para mais um esboço de $1^{\circ}$ capítulo ${ }^{41}$.

Procurei estabelecer um contexto histórico coerente para traçar um percurso da história do flagrante e de seu falseamento (a fotografia de rua, o papel das guerras, o fotojornalismo e o amadorismo), e estudar algumas fotografias pontuais dentro desse contexto como ferramenta para a análise de Menina na Chuva.

No decorrer da pesquisa, esse primeiro capítulo foi tomando diversas formas. Apesar disso, ele mantinha a idéia inicial de contextualizar historicamente o flagrante. A minha maior dificuldade foi justamente tomar a obra de German Lorca como foco sem deixar de lado o contexto histórico do flagrante e pseudoflagrante.

Em determinado momento comecei a trabalhar um confronto mais direto entre a fotografia Menina na Chuva, de Lorca, e Atrás da Estação Saint-Lazare, de Cartier-Bresson. Esse fato me levou a perceber que o capítulo estava caminhando para uma discussão pautada na autenticidade da fotografia Menina na Chuva, enquanto flagrante. Assim o re-denominei para Menina na Chuva: flagrante?, mas ainda não tinha resolvido completamente a questão do contexto histórico em relação a essa fotografia de Lorca.

A partir daí concluí que era preciso que esse contexto funcionasse, para que o trabalho pudesse acontecer de fato, e então o capítulo teria de ter um título que anunciasse isto: o flagrante.

\footnotetext{
${ }^{41} \mathrm{Na}$ versão entregue para a disciplina mencionada na nota de número 31, o lema de Lorca figurava como uma citação de abertura.
} 
Desenvolvendo o capítulo, foi me parecendo importante demonstrar que nos primórdios da fotografia, o que surge é a idéia de flagrante, gerada pela busca da instantaneidade. E para isso, tornou-se necessário voltar séculos na História da Arte e verificar como se deu a questão da captação do instante na Arte: notei que isso se deu por meio da busca pelo registro eficaz do movimento.

Para abordar o contexto sob esse aspecto, eu discutiria como Lorca se utiliza da instantaneidade por meio do flagrante e de seu falseamento.

Aqui retomo àquela questão da banca, no Exame de Qualificação, que solicitava minha posição quanto a Menina na Chuva ser ou não um flagrante. Na medida em que eu retrabalhava o capítulo inicial de minha dissertação, ia se tornando mais clara para mim a idéia de que essa fotografia poderia tanto passar por um flagrante quanto por um pseudoflagrante. Concluí que uma questão quase não se separa da outra nas fotografias de rua de Lorca, tornando-as intercambiáveis, como este estudo procura demonstrar nos capítulos 2 e 3. A meu ver, a fotografia Menina na Chuva, que me fascina tanto, é um exemplo fundamental dentro dessa visão. Afinal que fatores podem realmente validar que uma fotografia é ou não flagrada?

Entenderemos que Menina na Chuva é um flagrante, se partirmos da noção de flagrante enquanto o congelamento de uma ação: o ato de pular foi flagrado.

Por outro lado, a fotografia não foi obtida espontaneamente. Trata-se de uma encenação que Lorca propôs à sua sobrinha que possui uma narrativa para aproximá-la do flagrante. 
Foi nesse nível de reflexão sobre a ambigüidade inerente do meu objeto de estudo que redigi novamente meu primeiro capítulo, até chegar à versão que consta desta dissertação: A genealogia do pseudoflagrante.

Nesse capítulo inicial será constituída uma genealogia do que nesta dissertação denomino livremente de pseudoflagrante, isto é, um flagrante falso.

Como contexto para refletir sobre a prática do pseudoflagrante em German Lorca, o objetivo desta abordagem é demonstrar que o expediente de forjar um flagrante nasce simultaneamente com a vontade de realizar um flagrante autêntico, nos primeiros tempos da fotografia.

Tal expediente se manifestará em vertentes como a fotografia de rua, o fotojornalismo e a fotografia amadora, e, por este motivo, busca-se também apresentar um breve panorama de cada uma delas de maneira a esclarecer os usos do pseudoflagrante a partir do século XIX.

Cabe esclarecer que não se fará presente um estudo aprofundado do fotojornalismo neste capítulo ou no decorrer da dissertação, uma vez que se trata de um contexto para apontar em quais esferas o pseudoflagrante aparece e que uso se faz desse código fotográfico em tais âmbitos.

Desse modo, entre as principais questões que são abordadas como contexto neste capítulo, estão: o registro do movimento na arte, a imobilidade da pose em confronto com a espontaneidade do flagrante; o pseudoflagrante visto como processo de experimentação na busca da instantaneidade nos primórdios da fotografia, dado aos entraves técnicos para o congelamento da ação; o primeiro impulso na conquista da instaneidade com a utilização da estereoscopia a partir dos anos 1850; o fotojornalismo e as guerras no século XIX, em países da Europa e dos Estados Unidos, tanto como caminho para a captação de um 
flagrante quanto para o seu falseamento; e, finalmente, apontamentos sobre a fotografia de rua no Brasil no século XIX.

Antes desse contexto, o capítulo 1 apresentará a fotografia que deu origem a este estudo, Menina na Chuva, para abrir o debate sobre o pseudoflagrante como forma de lançar questões para o desenvolvimento de sua genealogia. Além disso, a apresentação dessa fotografia servirá de base para a discussão que permeará este estudo em torno dela e das outras quatro cenas de cotidiano, realizadas por German Lorca durante sua atuação no Foto Cine Clube Bandeirante entre os anos de 1949 a 1952.

O enfrentamento entre Menina na Chuva e Atrás da Estação Saint-Lazare, que mencionei anteriormente nesta introdução, se transformou em uma das principais questões do segundo capítulo deste trabalho: Menina na Chuva momento decisivo ou encenação?

Começo o capítulo buscando contextualizar a questão do flagrante no fotojornalismo no século XX na Europa e Estados Unidos, para introduzir o trabalho de Henri Cartier-Bresson que se inseriu dentro da proposta do humanismo francês. Nesse capítulo cito também o papel das guerras e da fotografia de acontecimentos sociais (Erich Salomon) no século XX para a discussão do flagrante e seu falseamento.

Neste contexto, a eleição de determinados fotógrafos ou fotografias em detrimento de outras é para que eles sirvam como exemplos pontuais que contribuam diretamente com a direção que tomou o meu tema. Isso explica, por exemplo, a razão pela qual entre as guerras que aconteceram no século $\mathrm{XX}$, escolho a Guerra Civil Espanhola e a fotografia Soldado Republicano (Federico 
Borrell Garcia) no momento de sua morte $(1936)^{42}$, de autoria de Robert Capa, para uma análise mais detalhada: tal escolha se deve ao fato de que sobre essa fotografia paira a dúvida com relação à sua autenticidade enquanto flagrante.

Como continuidade da reflexão sobre o possível pseudoflagrante de Capa, o próximo tópico do capítulo procura dar conta da conceituação de momento decisivo que introduz as aproximações possíveis entre as fotografias Atrás da Estação Saint-Lazare, de Cartier-Bresson, e Menina na Chuva, de German Lorca.

No decorrer do capítulo se estabelece um panorama da cultura visual em que German Lorca estava inserido nos anos 1950. Para constituir tal panorama, serão abordados: análises de alguns exemplares da revista Life International e O Cruzeiro, as quais apresentam fotografias de Henri CartierBresson e Jean Manzon, respectivamente, em comparação à algumas fotografias de Lorca realizadas no âmbito do Foto-Cine Clube Bandeirante; além da anteriormente citada exposição do Museu de Arte Moderna de Nova lorque, na Biblioteca Mário de Andrade. Na seqüência, aborda-se o contexto dos parâmetros fotográficos praticados por Lorca no $8^{\circ}$ Salão Internacional de Arte Fotográfico, do Foto-Cine Clube Bandeirante, com relação à produção de outros fotógrafos no mesmo salão.

No capítulo final, o terceiro, parto para a análise de algumas fotografias com as quais German Lorca teria participado do concurso "Dias de Chuva" Homem na Chuva, Menina na Chuva e Chuva na Janela, segundo depoimento do fotógrafo concedido à autora ${ }^{43}$ - além de quatro fotografias de rua de Lorca

\footnotetext{
${ }^{42}$ Essa fotografia é comumente conhecida como Morte de um Soldado Republicano.

${ }^{43}$ Ver detalhes sobre esse depoimento no referido capítulo.
} 
que selecionei, todas realizadas enquanto o fotógrafo era associado do FotoCine Clube Bandeirante: Cortiço no Brás (1949), Malandragem (1949), A Procura de Emprego (1950) e Apartamentos (1951) ${ }^{44}$.

Neste capítulo a principal discussão gira em torno da composição e o corte, partindo das noções que Lorca aprendeu no Foto Cine-Clube Bandeirante, uma vez que quase toda a sua produção fotográfica tem corte. Dessa forma, este capítulo baseia-se em artigos publicados sobre o tema nos boletins do Bandeirante.

A intenção dessa abordagem é demonstrar qual a importância do recurso do corte dentro da realização de flagrantes e pseudoflagrantes por Lorca, considerando que o fotógrafo utiliza-se desse expediente para oferecer ao espectador a cena da maneira como gostaria de tê-la flagrado.

Nas considerações finais apresento uma reflexão sobre o flagrante, o pseudoflagrante e as relações entre a composição e o corte na fotografia de German Lorca buscando destacar as principais questões apresentadas nesta dissertação.

\section{§§§§§}

\footnotetext{
${ }^{44}$ Essa seleção deve-se ao fato de este estudo considera-las emblemáticas para a discussão entorno do flagrante e do pseudoflagrante na obra do fotógrafo.
} 


\section{CAPÍTULO 1: A genealogia do pseudoflagrante}

\section{O pseudoflagrante em Menina na Chuva: base para uma genealogia}

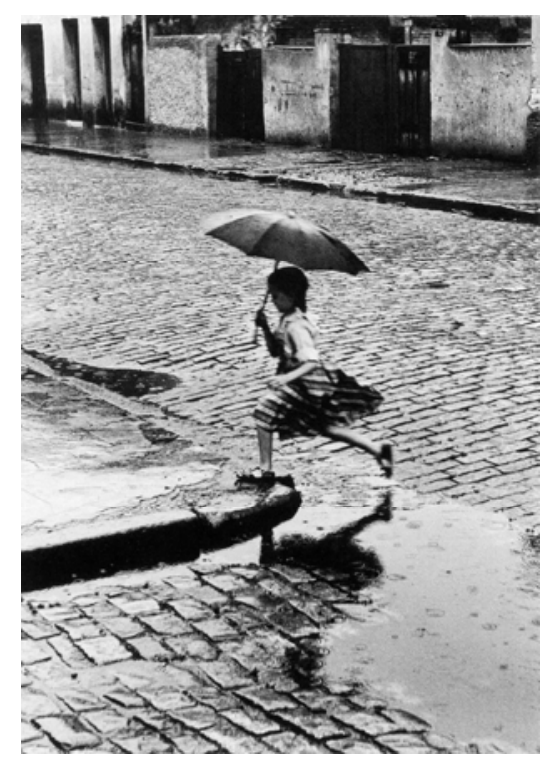

lustração 1: German Lorca. Menina na Chuva, 1950. Coleção Museu de Arte Moderna de São Paulo.

A fotografia Menina na Chuva [llustração 1] foi realizada por German Lorca dentro do contexto do Foto-Cine Clube Bandeirante, como se mencionou na introdução deste estudo. Em 1950, portanto dois anos após seu ingresso nessa agremiação, Lorca, segundo depoimento concedido à autora ${ }^{45}$, realiza essa fotografia para participar do "Concurso de Junho" sob o tema "Dias de Chuva", anunciado pelo Bandeirante no boletim do mês de maio ${ }^{46}$.

\footnotetext{
${ }^{45}$ Segundo esse depoimento concedido a autora pela primeira vez em 15 de abril de 2004 e reiterado em 04 de agosto de 2005, Lorca teria inscrito Menina na Chuva e outras fotografias com o tema chuva para participar do concurso "Dias de Chuva", como será visto no capítulo 3. Apesar de Menina na Chuva ter sido realizada com a finalidade de participar desse concurso, que ocorreu em 1950, a data oficial dessa fotografia, que consta da coleção do Museu de Arte Moderna de São Paulo, é 1951. Isso se deve, segundo depoimento de Lorca em entrevista concedida à autora em 4 de agosto de 2005, ao fato de o fotógrafo considerar o ano em que Menina na Chuva teria sido exposta pela primeira vez. Talvez seja esse o motivo da divergência de datas dessa fotografia em publicações, exposições e registros em coleções: variam de 1950 a 1953. Esta pesquisa não localizou a primeira exposição na qual Menina na Chuva teria participado em 1951. Foi encontrado o registro da participação dessa fotografia, então denominada Estudo com Menina, na individual que German Lorca realizou no MAM-SP em 1952, intitulada "35 Fotografias G. Lorca". Sobre a divergência de títulos de Menina na Chuva, ver nota de $n^{\circ}$. 14 na introdução deste estudo.

${ }^{46}$ Ver Boletim do Foto-Cine Clube Bandeirante Ano V - No 49 de maio de 1950. Seção "O Concurso de Junho", p. 23.
} 
A fotografia de Lorca que figura no boletim que apresenta as fotografias melhor classificadas nesse concurso é, contudo, Chuva na Janela ${ }^{47}$ [llustração 1.2], como será visto no capítulo 3 .

Aos Fotogratias do Mês

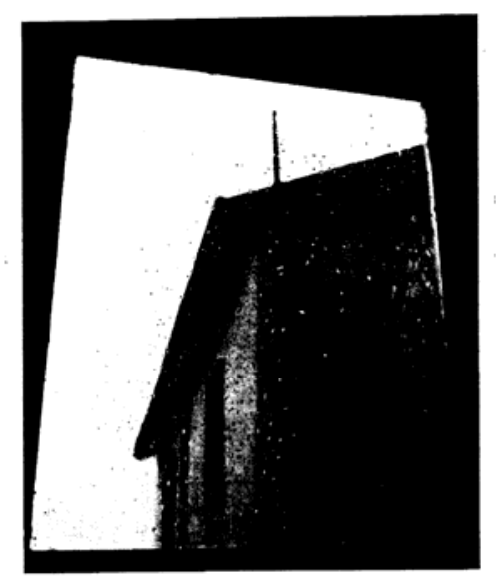

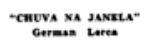

$-11-$

Ilustração 1.2: A fotografia Chuva na Janela, de German Lorca, publicada entre "As Fotografias do Mês" no Foto-Cine Clube Boletim edição de julho de 1950. Acervo do Foto-Cine Clube Bandeirante.

\section{§§§§§§§}

A fotografia Menina na Chuva mostra uma garota de guarda-chuva, sozinha, pulando uma poça de água em um dia chuvoso. A poça acumula-se ao redor da esquina de uma calçada e se estende até a rua de paralelepípedos, refletindo a imagem da garota. No plano desse reflexo vê-se também uma outra poça - menor que a primeira e com formato triangular-,

\footnotetext{
${ }^{47}$ Chuva na Janela foi publicada no boletim Ano V - $n^{\circ}$. 51, de julho de 1950, entre "As Fotografias do Mês" (as fotografias publicadas como "do mês", eram aquelas que obtinham melhor classificação nos concursos internos).
} 
localizada paralelamente à esquina que funciona como uma seta que aponta para o pulo.

Atrás da garota, no outro lado da rua, são vistos muros dos portões de casas, dado que indica que ela estava atravessando a rua de um bairro residencial.

As linhas paralelas, formadas pela calçada à qual a menina se dirige e por aquela onde estão as casas, emolduram o punctum ${ }^{48}$ da fotografia: o pulo.

Como em um flagrante, esse pulo é captado por German Lorca no exato momento em que acontece: observe-se o congelamento do ato de pular que registra a garota com um pé na esquina da calçada e outro ainda no ar.

Nada nessa fotografia nos leva a crer que não se trata de um flagrante. Pelo contrário, Menina Chuva foi incorporada ao Acervo do Museu de Arte Moderna de São Paulo, como exemplo dessa categoria ${ }^{49}$.

Cabe aqui perguntar até que ponto a autenticidade da espontaneidade dessa fotografia seria questionada se não fosse o próprio Lorca a fazê-lo: em várias oportunidades o fotógrafo afirmou que fez "a fotografia Menina na Chuva acontecer ${ }^{50 "}$

Lorca esclareceu que estava à janela de sua residência, na Rua Almirante Barroso (no bairro do Brás), observando a rua num dia chuvoso, quando Ihe surgiu a idéia de solicitar à sua sobrinha Eunice — filha de sua irmã

\footnotetext{
${ }^{48}$ Segundo Roland Barthes: "A esse segundo elemento que vem contrariar o studium chamarei, então, punctum; pois punctum é também picada, pequeno buraco, pequena mancha, pequeno corte - e também lance de dados. $\mathrm{O}$ punctum de uma foto é esse acaso que, nela, me punge (mas também me mortifica, me fere)". Ver BARTHES, Roland. A Câmara Clara. Rio de Janeiro: Editora Nova Fronteira, p. 44.

${ }^{49} \mathrm{Em}$ aparte no debate decorrente da apresentação da mesa-redonda realizada no XXIV Colóquio do Comitê Brasileiro de História da Arte em 28 de outubro de 2004, intitulada O Fotógrafo e sua obra, na qual apresentei uma comunicação sobre o tema de minha dissertação, o pesquisador Tadeu Chiarelli afirmou que em 2000, quando ele era curador-chefe do MAM-SP, Menina na Chuva foi incorporada ao acervo desse Museu como um exemplo de flagrante dentro da obra de Lorca.

${ }^{50}$ Lorca afirmou que ele tinha feito a fotografia Menina na Chuva "acontecer" em 22 de outubro de 2003, quando fui pela primeira vez entrevista-lo em seu estúdio. Depois, confirmou essa afirmação por e-mail em 03 de dezembro do mesmo ano, como foi mencionado na introdução desse estudo. Em outras entrevistas, realizadas ao longo do ano de 2004, Lorca voltaria a falar sobre a encenação da fotografia Menina na Chuva. Sobre o lema de German Lorca "A fotografia acontece e ele a faz acontecer", ver nota de $n^{\circ}$. 29 na Introdução deste estudo.
} 
e vizinha - que pulasse uma poça de água na rua. Eunice, então com sete anos, repetiu a cena algumas vezes para que o fotógrafo obtivesse a foto desejada ${ }^{51}$.

Em entrevista concedia à autora, Eunice, a primeira sobrinha de Lorca, atualmente com 64 anos, contou que era modelo do seu tio: "meu tio realizou várias fotografias das quais fui modelo. Eu era criança, estava na primeira série e me sentia importante em ser modelo de um tio fotógrafo ${ }^{52 " .}$

Ainda nessa entrevista Eunice relatou a respeito de sua participação em Menina na Chuva:

Minha participação nessa fotografia foi especial. Eu morava em uma vila na Rua Almirante Barroso e freqüentava muito a casa do meu tio. Pulei algumas vezes a poça d'água, não lembro quantas, pois eu era pequena. Existe outra fotografia, da mesma época, em que meu tio me fotografou fazendo lição perto da janela [llustração 1.3]. Acho que no estilo de flagrante encenado, só fiz Menina na Chuva ${ }^{53}$.

\footnotetext{
${ }^{51}$ Lorca iria contar, publicamente, os bastidores da realização da fotografia Menina na Chuva, na mesma palestra mencionada na nota de $\mathrm{n}^{\circ}$. 34 da introdução ("O estético e o social na trama fotográfica").

${ }^{52}$ Entrevista concedida a autora por telefone em janeiro de 2006.

${ }^{53}$ Idem. ibidem. Nessa entrevista Eunice demonstrou, em um primeiro momento, dúvidas quanto a idade que teria na época da realização de Menina na Chuva. Lembrou que estava na $1^{\text {a }}$ série e que, portanto, deveria ter sete anos. Ou acabado de completar oito: o concurso "Dias de Chuva" foi anunciado em maio de 1950. Um mês antes, Eunice completava oito anos. Eunice relata que essas e outras fotografias realizadas por German Lorca na Rua Almirante Barroso foram feitas antes de 1952, quando os Lorca mudaram-se do bairro do Brás. Lorca fez o seguinte comentário sobre a fotografia de Eunice estudando, logo em uma das primeiras entrevistas concedidas à autora (15.04.2004). "É uma fotografia espontânea. Ela estava perto da janela fazendo uma lição e eu bati a foto com essa luz. Não é uma luz dramática, mas é bonita, né?"
} 


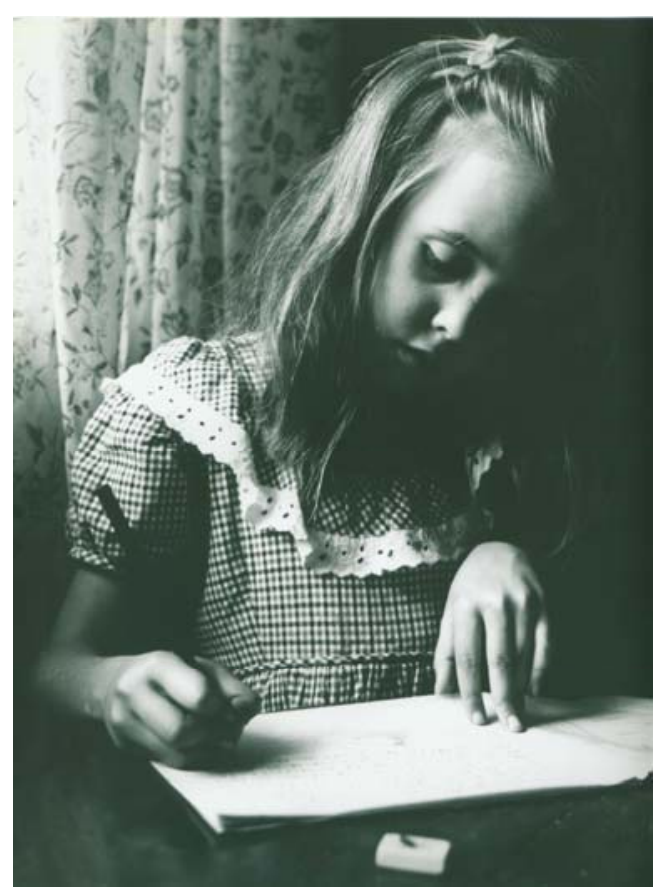

Ilustração 1.3: A fotografia de Eunice estudando perto da janela, 1950. Acervo de German Lorca.

Ao contrário do que possa parecer, portanto, German Lorca não teve a sorte de flagrar essa cena de uma criança solitária atravessando a rua em um dia chuvoso. Menina na Chuva é resultado de uma encenação idealizada por Lorca, que a tinha concebido previamente, com a intenção de produzir uma fotografia para participar do mencionado concurso.

\section{$\underline{\text { A vontade de registrar o movimento e a instantaneidade na arte }}$}

Se no século XX foi possível para German Lorca congelar o movimento em fotografias como Menina na Chuva, isto se deu, porque houve uma evolução técnica desse tipo de registro ao longo do século anterior: o século XIX, com o advento da fotografia, caminhava para a solução da questão do 
registro do movimento, herdando um problema surgido no âmbito das artes plásticas.

A necessidade de captar o movimento caracteriza um problema que antecede a técnica fotográfica: a escultura, a pintura, o desenho e a gravura já mostravam as tentativas dos artistas de realizar um registro digno do movimento, fosse humano, animal ou de objetos. Tal necessidade estaria ligada à idéia de representar a natureza de modo próximo ao real e nasce no seio da Arte Ocidental, especialmente, com a arte grega, do século $\mathrm{V}$ a.C., atravessando toda a História da Arte a partir daí.

A captação do movimento segundo a idéia de representação próxima ao real será vista, primeiro, na escultura grega.

O que o historiador Ernst Gombrich chama de "a grande revolução da arte grega", notadamente quando a questão do movimento entrará em voga, acontece por volta do século $\mathrm{V}$ a.C., período em que:

(...) o povo das cidades gregas começa a contestar as antigas tradições e lendas sobre os deuses, e a investigar sem preconceitos a natureza das coisas. É o período em que a ciência, tal como entendemos hoje o termo, e a filosofia despertam pela primeira vez entre os homens, e em que o teatro se desenvolveu a partir das cerimônias em honra de Dionísio ${ }^{54}$.

O apogeu do desenvolvimento da arte grega chegaria na mesma época em que a democracia estava em seu ponto alto, isto é, no governo de Péricles. A partir de Fídias, os artistas gregos, baseados em conceitos da pintura egípcia tais como, demonstrar a coesão corporal humana pela estrutura do

${ }^{54}$ GOMBRICH, E. H. A História da Arte. Rio de Janeiro: Editora Guanabara, 1988. trad. Álvaro Cabral, $4^{\text {a }}$ edição, p.52. 
corpo e suas principais articulações, passaram a se aprofundar na exploração de ossos e músculos em suas obras. Com isso, buscavam “(...) formar uma imagem convincente da figura humana, a qual permanecesse visível, mesmo sob a ondulação de roupagens ${ }^{55 " \text {. }}$

Esse é um aspecto que contribuirá para uma representação convincente do movimento na escultura grega. O outro, será o tipo de trabalho que os artistas gregos eram freqüentemente solicitados a realizar, pautado no corpo humano em ação: trata-se das estátuas de atletas vitoriosos que se localizavam ao redor do templo de Olímpia e eram dedicadas aos deuses, como é o caso de Discóbulo [llustração 1.4], realizada por Míron de Elêuteras, escultor ateniense da geração de Fídias, por volta de 450 a.C..

Discóbulo representa um jovem atleta no momento em que está prestes a lançar um disco.

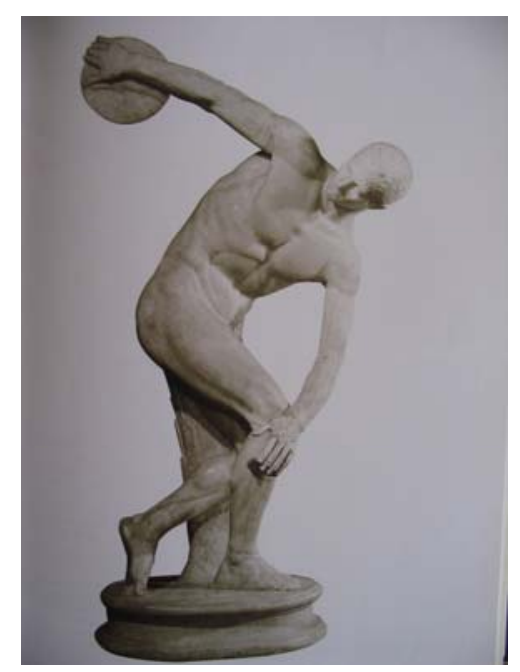

Ilustração 1.4: Discóbulo, Míron de Elêuteras. Cópia romana dita Lancelloti, 480-460 a.C., cópia em gesso. Museo Nazionale Romano di Palazzo Altemps, Roma.

${ }^{55}$ Idem. Ibidem. p. 56 
De tão convincente, a maneira como o atleta representado na estátua flexiona o corpo (tronco posicionado de maneira frontal, levemente dobrado na região do abdômen, o braço projetado para trás para lançar o disco e pernas flexionadas), serviu de modelo para o aprendizado de lançamento de disco por atletas modernos.

Ermest Gombrich reflete sobre o movimento de Discóbulo paralelamente à tradição da arte egípcia:

Se nos colocarmos diante da estátua e nos concentrarmos apenas em seus contornos, damo-nos subitamente conta de sua relação com a tradição da arte egípcia. Tal como os pintores egípcios, Myron deu-nos o tronco em vista frontal, as pernas e os braços em vista lateral; à semelhança daqueles compôs a imagem do corpo de um homem segundo os planos visuais mais característicos de suas partes (...). Em vez de combinar esses planos visuais na representação inconvincente de uma pose rígida, pediu a um modelo real que posasse numa atitude semelhante e adaptou-a de tal modo que nos dá a impressão de ser a reprodução convincente de um corpo em movimento. Se isso corresponde ou não ao movimento exato mais adequado e eficaz para lançar o disco pouca importância tem. O que importa é que Myron conquistou o movimento, tal como os pintores de seu tempo conquistaram o espaço ${ }^{56}$.

\section{Giulio Carlo Argan detém-se na questão da representação do movimento} nessa estátua:

O Discóbulo, conhecido por intermédio de várias cópias (...) é um exemplo de 'ponderação', chegando ao virtuosismo. Toda a figura, dobrada num grande arco elástico, apóia-se sobre a perna direita. À perna esquerda, já erguida no impulso final do arremesso, opõe-se o braço que se une ao joelho direito. Com seu movimento, a

\footnotetext{
${ }^{56}$ Ver GOMBRICH, Ernest. Op. cit. p. 59.
} 
figura traça duas grandes curvas: uma, mais estreita, formada pelo fêmur direito e pelo torso, dá origem à outra, mais ampla, dos braços. Mas o centro ou nós do movimento, todos levados ao braço estendido para trás com o disco, estão distribuídos em diversos planos ou níveis: as correntes de força desenvolvem-se em espiral, com um duplo ritmo de concentração e impulso, de modo que a força do gesto permanece imutável de qualquer ponto que se olhe para a estátua $(\ldots)^{57}$

Os anos compreendidos entre 520 e 420 a.C. foram fundamentais para que em fins do século $V$ a.C., os artistas gregos tomassem consciência de sua maestria.

As obras de arte não obedeceriam mais apenas funções religiosas e políticas e a partir daí surgiriam vários estilos e tradições em diferentes cidades, as chamadas "escolas de arte".

A arte grega do século IV terá no escultor Praxíteles seu maior expoente. Suas esculturas representam um movimento muito mais solto do que naquelas realizadas por escultores da geração anterior, como em Hermes com o jovem Dionísio, de 350 a.C. [llustração 1.5].

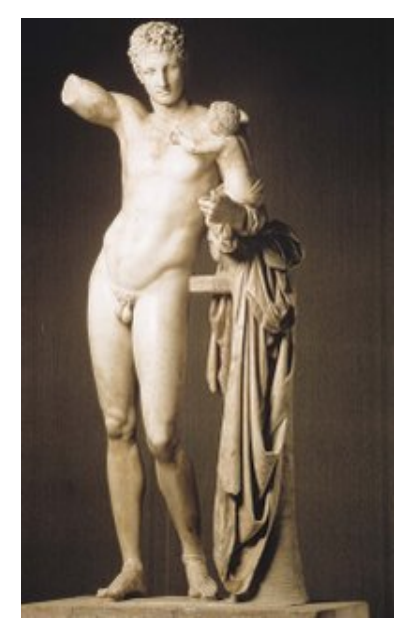

Ilustração 1.5: Praxíteles, Hermes com o jovem e Dionísio. 350 a.C., Olímpia Museu. ${ }^{57}$ Ver ARGAN, Giulio Carlo. História da Arte Italiana: da Antiguidade a Duccio - v.1. São Paulo: Cosac\&Naify, 2003, p.
83. 
O período após Praxíteles, conhecido como helenístico (governo de Alexandre Magno), será notório tanto pelo retrato escultórico como pelas esculturas de batalhas e de grupos, que retomarão a questão do movimento.

Na escultura de grupos figura Laocoonte e seus filhos [llustração 1.6], realizada no século I, em 25 a.C., na oficina de Hagesandro, Atenodoro e Polidoro de Rodes.

A escultura refere-se ao episódio em que duas gigantescas serpentes do mar apanham o sacerdote troiano Laocoonte e seus filhos para estrangulá-los, depois da traição do sacerdote para com seus compatriotas quando os adverte a não aceitar o cavalo de madeira que continha soldados gregos.

Note-se que em Laocoonte e seus filhos, a sensação de movimento gerada pela contorção dos corpos narra o fato: o embate que o pai e os filhos enfrentam inutilmente para se livrarem das serpentes. Ao mesmo tempo, parece que a obra capta o instante em que Laocoonte e seus filhos tentam se livrar delas.

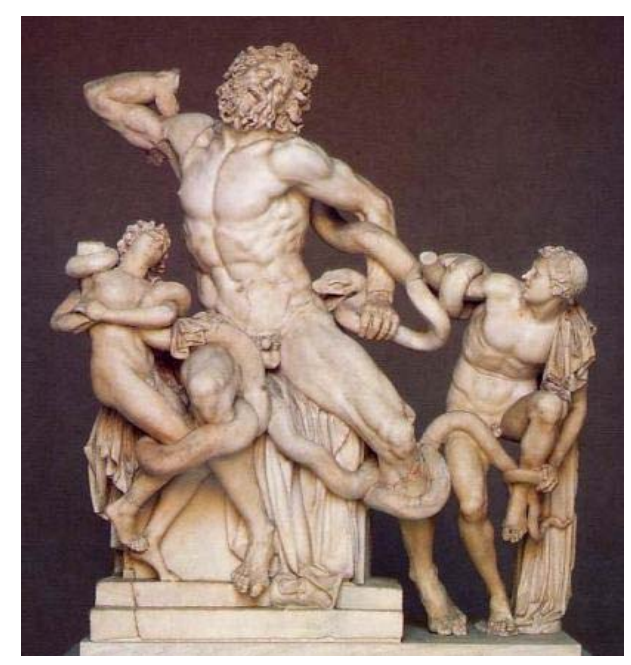

Ilustração 1.6: Laocoonte e seus filhos. Grupo em mármore proveniente da oficina de Hagesandro, Atenodoro e Polidoro de Rodes. Cerca de 25 a. C. Museu do Vaticano. 
Nos séculos I a IV d.C., período que abarca as realizações dos povos conquistadores do mundo - romanos, budistas, judeus e cristãos -, observa-se tanto a tentativa de passar a idéia de um movimento fluído em obras de arte, como a não observância desse aspecto.

Inspirados nos costumes de povos do Antigo Oriente - que tinham o hábito de contar suas vitórias em campanhas militares por meio da arte -, os artistas romanos passariam a realizar reportagens de guerra, mas com um diferencial: o registro do movimento próximo do natural em oposição à aparência rígida das composições realizadas pelas antigas civilizações orientais.

Os romanos empregavam recursos da arte grega ${ }^{58}$ para construir seus retratos de guerra, acrescentando à harmonia e à expressão dramática herdada da arte helenística, a representação pormenorizada do feito. Esse expediente resultava em uma representação convincente de movimento que, assim como na arte grega, parecia fluído e natural.

Esse é o caso da coluna gigantesca que Trajano ${ }^{59}$ erigiu para mostrar "a crônica ilustrada de suas guerras e vitórias na Dácia (a Romênia moderna) ${ }^{60}$ " [llustração 1.7].

\footnotetext{
${ }^{58} \mathrm{~A}$ arte romana herdou preceitos da arte helenística dos gregos que se aplicaram, principalmente, em monumentos arquitetônicos da cidade de Pompéia, como o Coliseu (construído cerca de 80 d.C.). "Era típico dos romanos adotarem da arquitetura grega aquilo de que gostavam e aplica-lo às suas próprias necessidades. Fizeram o mesmo em todos os campos. Uma de suas principais necessidades era de bons retratos que representassem fielmente os modelos reais". Cabe observar que no período em que os romanos conquistavam o mundo e fundavam o seu império sobre as ruínas dos povos helênicos, a arte romana sofreu poucas modificações. (Ver GOMBRICH, E. H. Op. cit. p. 82)

${ }^{59}$ A coluna de Trajano possui 29,7 metros de altura e foi inaugurada em 114 d.C.

${ }^{60}$ Ver GOMBRICH, E. H., p. 85.
} 

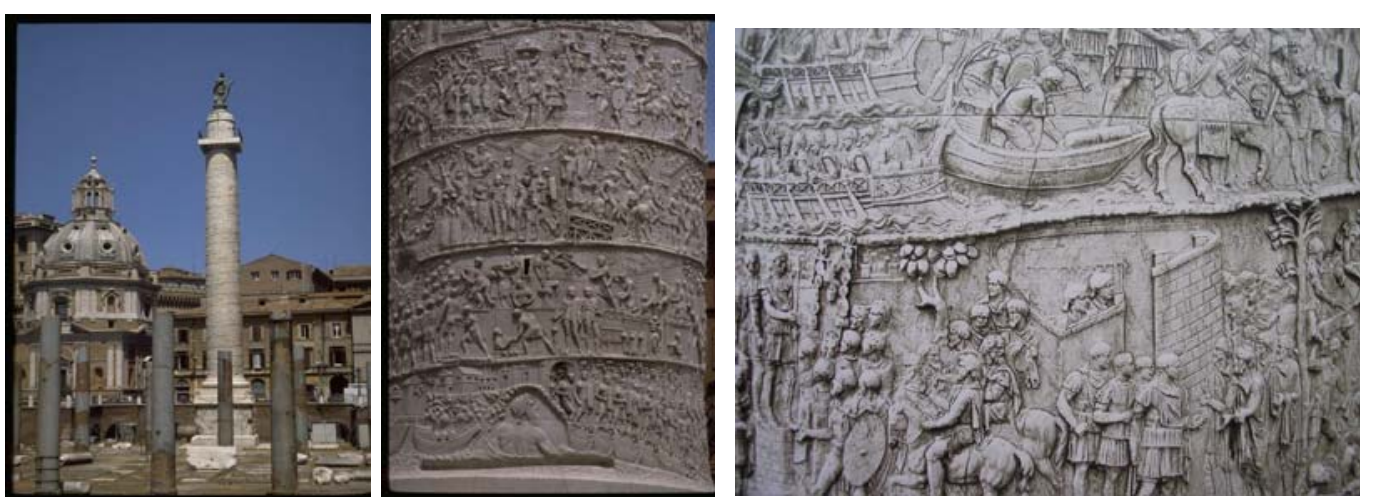

Ilustração 1.7: Coluna de Trajano. Panorâmica (à esquerda) e detalhes (ao centro e à direita). Roma, Itália.

A busca por representar a natureza de modo convincente na arte, e, por conseqüência, por expressar naturalidade no movimento, deixaria de ser enfatizada até a arte gótica de meados do século XIII. Dos séculos V ao início do XIII, a arte passaria por modificações e voltaria, fundamentalmente, a ter uma aparência tão rígida quanto a da arte primitiva:

(...) a arte cristã da Idade Média tornou-se uma curiosa mistura de métodos primitivos e sofisticados. O poder de observação da natureza, a cujo despertar assistimos na Grécia, por volta de 500 a.C., voltou a adormecer por volta de 500 d.C. Os artistas deixaram de cotejar suas fórmulas com a realidade. Não mais se dispunham a fazer descobertas sobre o modo de representar o corpo ou de criar a ilusão de profundidade. Mas as descobertas que tinham sido feitas nunca se perderam. A arte greco-romana forneceu um imenso repertório de figuras em pé, sentadas, curvadas ou caindo. Todos esses tipos poderiam ser comprovadamente úteis para contar uma história e assim é que foram assiduamente copiadas sempre a novos contextos. Mas a finalidade de seu uso era agora tão radicalmente diversa que não nos pode surpreender o fato de, superficialmente, as pinturas revelarem pouco de sua origem clássica ${ }^{61}$.

\footnotetext{
${ }^{61}$ Ver GOMBRICH, E. H., op. cit. p. 96 e 97.
} 
Nesse período, marcado pelo cristianismo, a questão da finalidade apropriada da arte em igrejas foi um fator importante para a história da Europa. Havia todo um debate em torno da estatuária e da pintura. No governo do Imperador Constantino, não seriam aceitas estátuas na Casa do Senhor por se parecerem "demais com aquelas imagens esculpidas de ídolos pagãos que a Bíblia condenava ${ }^{62 " ~ e ~ t a m b e ́ m ~ p o r ~ p r e v e r ~ a ~ p o s s i b i l i d a d e ~ d e ~ c o n f u n d i r ~ o s ~}$ cristãos recém-convertidos pois:

(...)como os míseros pagãos que tinham se convertido recentemente à nova fé apreenderiam a diferença entre suas antigas crenças e a nova mensagem, se vissem tais estátuas nas igrejas? Poderiam facilmente pensar que uma estátua 'representa' realmente Deus, tal como pensavam antes que uma estátua de Fídias representa $\operatorname{Zeus}(\ldots)^{63}$

$\mathrm{Na}$ pintura, essa mesma questão seria vista de modo diferente, especialmente na parte latina do império romano. Considerava-se útil a pintura de tais imagens, de modo a ajudar a congregação "a recordar os ensinamentos que haviam recebido e mantinham viva a memória desses episódios sagrados $^{64 "}$.

Sobre essa discussão, o Papa Gregório, o Grande, que viveu no final do século VI d.C., ponderava que "A pintura pode fazer pelos analfabetos o que a escrita faz para os que sabem ler ${ }^{65 "}$.

Dessa forma, para que o tipo de pintura que o Papa pregava fosse admitida, "a história tinha de ser contada da maneira mais clara e simples

\footnotetext{
62 Idem,ibidem, p.95

63 Idem, ibidem.

64 Idem, ibidem.

${ }^{65}$ Idem, ibidem
} 
possível, e tudo o que pudesse desviar a atenção dessa finalidade principal e sagrada deveria ser omitido ${ }^{66 "}$.

Com o século XIII chega o estilo arquitetônico gótico, nascido na França setentrional, que seria empregado primeiro nas catedrais francesas.

Na escultura, esse estilo retoma padrões clássicos, como mostrar a estrutura do corpo sob as vestes de estátuas e relevos, fato que trará de volta a questão da representação convincente da natureza de modo que pareça tão animada quanto no real ${ }^{67}$.

No relevo A Morte da Virgem [llustração 1.8] realizado no pórtico do transepto sul da catedral de Estrasburgo em cerca de 1230, já é possível notar essa retomada, embora ainda existam resquícios da maneira de representação do século anterior tais como a simetria solene das figuras.

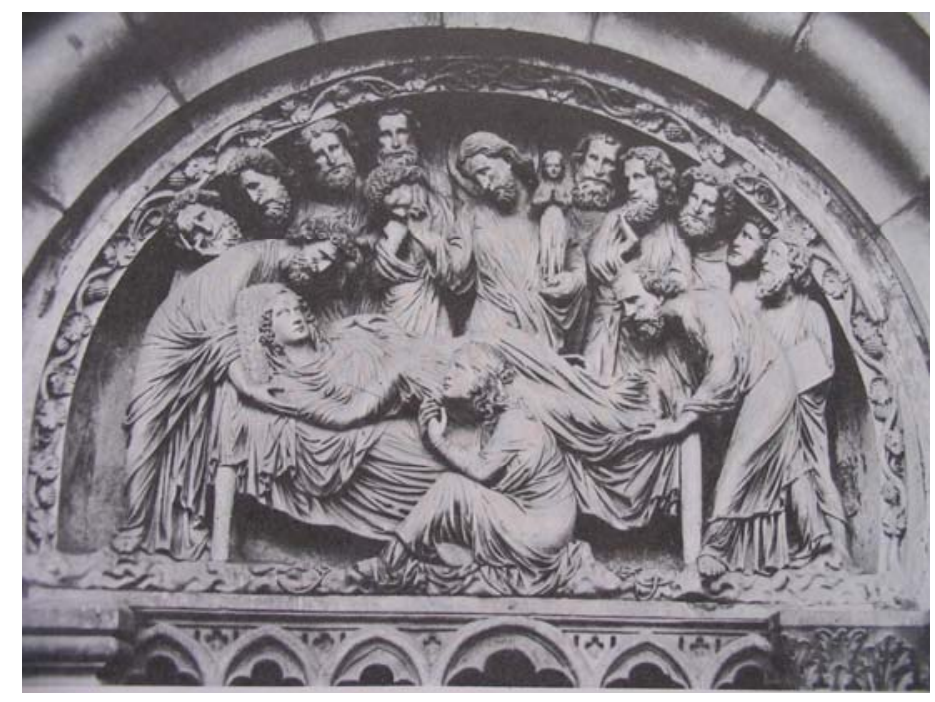

Ilustração 1.8: Relevo A Morte da Virgem. Pórtico do transepto sul da catedral de Estrasburgo. Cerca de 1230.

\footnotetext{
${ }^{66}$ Idem.ibidem.

${ }^{67}$ Segundo Ernest Gombrich apesar de a arte gótica basear-se em preceitos da arte grega existe uma "vasta diferença" entre ambas e entre "a arte do templo e da catedral". "Os artistas gregos do século V a. C. estavam principalmente interessados em como realizar a imagem de um belo corpo. Para o artista gótico, todos esses métodos e estratagemas eram tão só um meio para um fim, que era contar uma história mais comovente e mais convincente. Não a conta apenas por contar, mas para nos transmitir uma mensagem, e para alívio e edificação dos fiéis". (Ver GOMBRICH, E. H., op. cit., p. 144).
} 
Observe-se que é possível perceber que existe um corpo sob as vestes cujas ondulações contribuem com a idéia de movimento, assim como a torsão dos corpos. Além disso, os rostos das figuras representadas possuem expressões, como a de dor, o que passa idéia de que "têm vida".

Enquanto os escultores tinham como principal tarefa trabalhar para as catedrais, os pintores se incumbiam frequentemente das ilustrações de manuscritos, que diferia das "solenes páginas dos manuscritos românicos"68".

Na pintura de manuscritos do século XIII se notará a vontade de passar a idéia de "sentimento", mais do que a de fazer com que as figuras parecessem naturais.

Será nesse mesmo século, que os artistas abandonarão, em algumas ocasiões, os seus livros de modelos para desenhar algo que lhes interessasse captado na própria vida real ${ }^{69}$.

O século XIII se tornaria conhecido como a época das grandes catedrais. Nesse período, a França figurava como o país mais importante e rico da Europa enquanto a Itália vivia um período de constantes guerras internas. Desse modo, a Itália demorará a aceitar as idéias e métodos dos construtores das grandes catedrais francesas góticas, embora a Alemanha e a Inglaterra já imitassem o padrão francês. Essa demora será observada também na

\footnotetext{
${ }^{68}$ Idem, ibidem.

69 Não era comum ao artista medieval munir-se de um livro de esboços e sentar-se diante de um objeto real para desenhá-lo. Pelo contrário: tais artistas dispunham de "livros de modelos" que traziam tipologias de representação dos principais temas da época, como santos e reis, por exemplo, para que servissem de base para seus desenhos. Porém, em certas ocasiões alguns artistas desenhavam a partir de um objeto real. Ernest Gombrich cita o caso de um retrato de elefante desenhado pelo historiador inglês Matthew Paris, em meados do século XIII, que seria enviado pelo rei da França, S. Luís, a Henrique III, em 1255. Nesse retrato o artista se preocupa com as proporções certas do elefante e insere no desenho a seguinte legenda "pelo tamanho do homem aqui retratado podereis imaginar o tamanho do animal representado aqui”. (Ver GOMBRICH, E.H. op. cit. p. 147)
} 
escultura italiana do período, com exceção de obras de alguns escultores como Nicola Pisano, da escola pisana ${ }^{70}$.

\section{Segundo Giulio Carlo Argan:}

A primeira obra pisana de Nicola é o púlpito do batistério de Pisa, terminado em 1260. É um organismo unitário, isolado, autônomo; e nele seria difícil distinguir o elemento arquitetônico do escultórico, de tal modo estão fundidos (...) As esculturas estão ordenadas em três zonas: embaixo, os leões e figuras acocoradas que servem de pedestal às colunas, no meio, os profetas e os evangelistas nos triângulos esféricos dos arcos e estátuas angulares de santos e de figuras alegóricas; no parapeito, os relevos com a Natividade, a Adoração dos Magos, a Apresentação ao Templo, a Crucificação, o Juízo. Há um conceito de fundo: a hierarquia ideal desde os símbolos profundos e das forças naturais (os leões e os telamões) ao domínio das forças espirituais (as Virtudes e os profetas) e, deste, ao tempo histórico da revelação divina, que se identifica com a vida terrena de Cristo e tem, como termo último, o Juízo. No giro desse pensamento, cada imagem tem significados complexos, cujos precedentes foram encontrados nas tradições doutrinárias e iconográficas da arte lombarda, toscana e francesa. Nicola opera, portanto, uma síntese de culturas, tanto na ordem das formas quanto na ordem inseparável, dos conteúdos; e é síntese, não combinação ou compromisso, porque individualiza o princípio e o fundamento daquelas culturas com suas ligações comuns com a Antigüidade romana e cristã ou, mais precisamente, em uma consciência "clássica" da histórica, propriamente realizada pelo cristianismo e finalizada para a salvação ${ }^{71}(\ldots)$

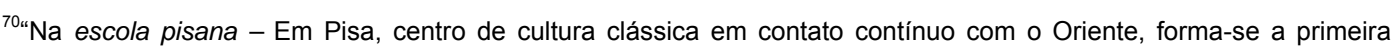
grande escola de escultura. Esta não é mais uma atividade complementar da arquitetura, ligada ao canteiro e às suas técnicas; é uma arte ou uma disciplina cuja autonomia é tanto mais legítima quanto mais diretamente relacionada à arte antiga romana, cujos documentos figurativos são justamente obras de escultura". Nicola Pisano seria uma "personalidade bem definida, apesar de anônima" que entrelaça "uma iconografia tradicional e uma plástica finamente modulada, ainda bizantina, a um sentimento que se pode dizer clássico, do enquadramento das figuras no espaço, a uma ordem 'histórica' da composição". Ver ARGAN, Giulio Carlo, op. cit., p. 386.

${ }^{71}$ Idem, ibidem, p. 387.
} 
No relevo Anunciação e Natividade, do batistério de Pisa [Ilustração 1.9], Nicola Pisano combina métodos da arte grega, como mostrar a forma humana sob as ondulações das vestes fazendo com que as figuras pareçam mais realistas do que estáticas, e da romana, no que diz respeito ao detalhamento das figuras (tanto humanas quanto de animais), embora tenha seguido a prática da arte medieval de combinar várias histórias em um mesmo quadro.

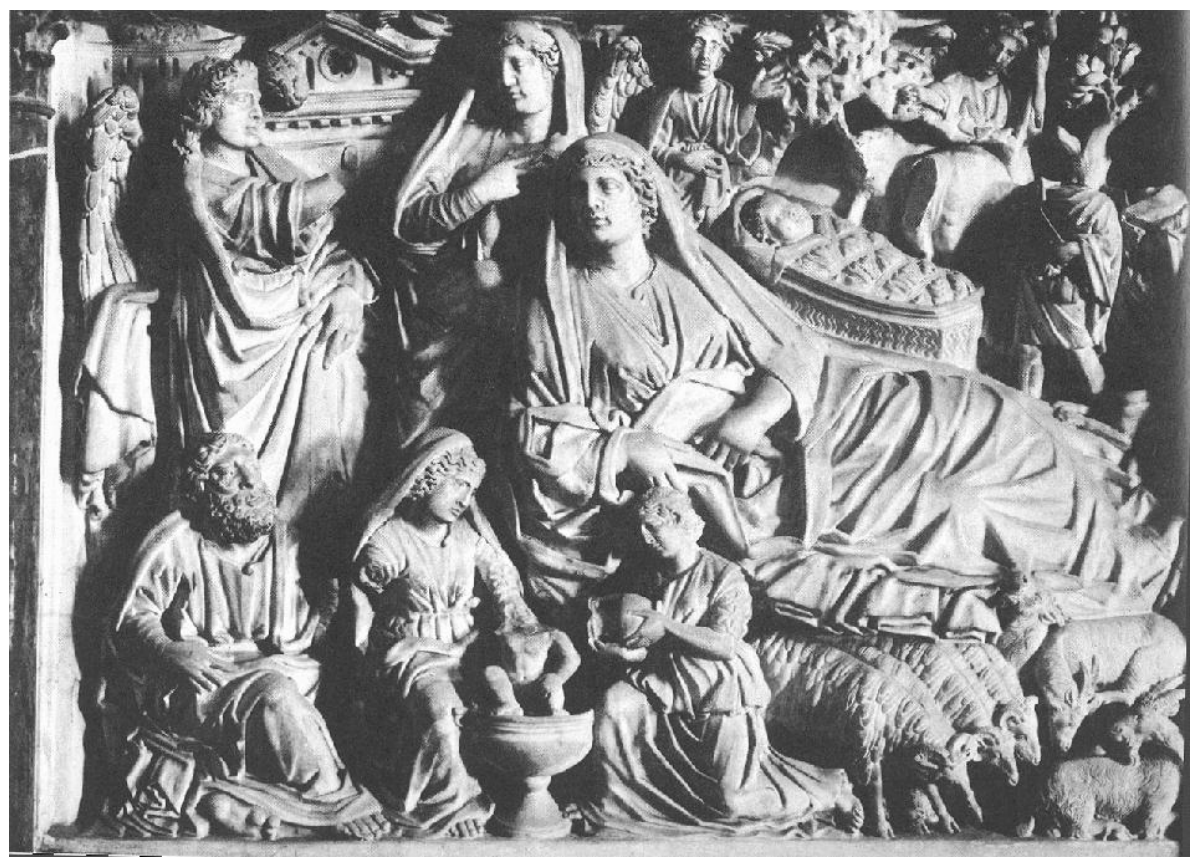

Ilustração 1.9: Nicola Pisano, Anunciação e Natividade. Relevo do púlpito em mármore do Batistério de Pisa, concluído em 1260.

Diferentemente da escultura que já por volta de 1260 passaria a empregar o estilo gótico, a pintura italiana o faria quarenta e seis anos depois pelas mãos do pintor florentino Giotto di Bondone, que iria "traduzir para a pintura as figuras realistas da escultura gótica" ${ }^{72 ":}$

\footnotetext{
${ }^{72}$ Ver GOMBRICH, E. H. op. cit. p. 150 e ARGAN, Giulio Carlo, op. cit. ,vol.2, (De Giotto a Leonardo) p.21 e 22. Segundo Argan "Giotto fez renascer a pintura morta havia séculos, conferindo-lhe naturalidade e nobreza. O período em que a arte esteve como morta é aquele em que fora dominada pela influência bizantina, libertando-a, Giotto religa-a à fonte clássica, a uma arte cujos conteúdos essenciais eram a natureza e a história. Para os homens do Medievo a Antigüidade é o mundo da filosofia "natural": a naturalidade de Giotto não nasce da observação direta do verdadeiro, mas é recuperada do antigo por meio do processo intelectual do pensamento histórico(...)"
} 
Os pintores italianos foram ainda mais morosos do que os escultores italianos em responder ao novo espírito dos mestres góticos. Cidades italianas como Veneza estavam em estreito contato com o Império Bizantino e os artífices italianos preferiam voltar seus olhos para Bizâncio ao invés de Paris, em busca de orientação e inspiração. As igrejas italianas do século XIII ainda eram decoradas com solenes mosaicos "a maneira grega"73.

Do pintor, destaca-se o mural A Lamentação do Cristo [llustração 1.10], provavelmente concluído em $1306^{74}$.

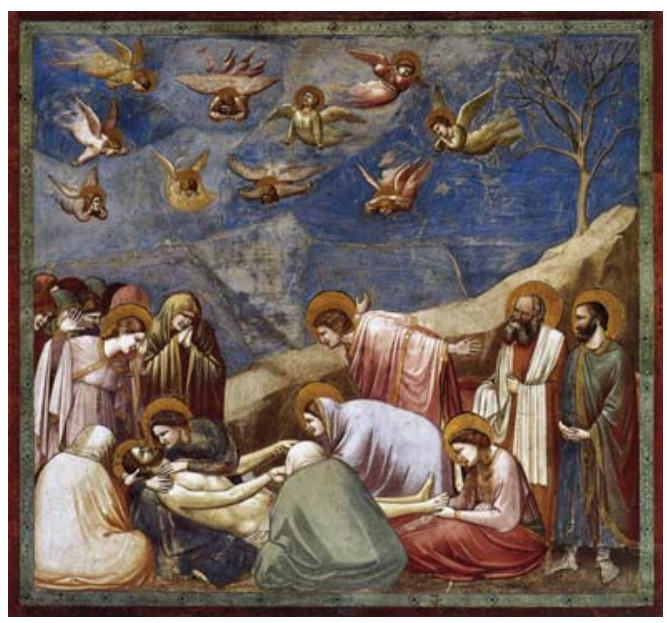

Ilustração 1.10: Giotto di Bondone. A Lamentação do Cristo, 1304-1306. Mural na Capella dell'Arena, Pádua.

Nesse mural Giotto introduz novos padrões na pintura deixando de lado a idéia de que "as figuras tinham de ser completamente mostradas ${ }^{75}$ ", quase como se fazia na arte egípcia, mostrando apenas parte dos corpos das figuras.

Giotto levará às últimas conseqüências a idéia que marca a arte gótica de que as figuras devem passar sentimento de modo a parecer vivas: o pintor apresenta uma maneira de representação pictórica tão teatral, conferindo

\footnotetext{
${ }^{73}$ Ver GOMBRICH, E. H. p. 149

${ }^{74}$ Data do mesmo ano a conclusão do mural "A Fé", localizada na Capella dell'Arena, em Pádua, em que Giotto pinta a figura da Fé com um ilusionismo tal que parece que estamos diante de uma estátua e não de uma pintura. Nessa pintura, Giotto literalmente traz para a pintura o realismo da escultura gótica. Ver GOMBRICH, E. H. op. cit, p. 150 e151.

${ }^{75}$ Idem, ibidem. p. 152
} 
tamanha importância às expressões e atitudes das figuras, que transmite a sensação de "que testemunhamos o evento real como se estivéssemos em um palco $^{76 "}$.

Essa teatralidade influirá no modo de representação do movimento: diferentemente da organização espacial das miniaturas pintadas em manuscritos da época, a disposição das figuras de $A$ Lamentação de Cristo são espaçadas e possuem respiro, fato que transmite a sensação de que podem se movimentar. Além disso, a torsão dramática dos corpos que se inclinam em direção ao Cristo também contribui para a idéia de movimento.

O século seguinte (XIV), conhecido como Pré-Renascença, em linhas gerais, foi marcado pela necessidade da Arte de melhor representar a natureza. Para tanto os artistas passariam a fazer estudos a partir do natural para depois representar a natureza em seus quadros, trocando o livro de modelos pelo de esboços.

Um exemplo dos reflexos dessa necessidade foi a maneira detalhada como os artistas estudavam a representação de animais vivos em seus esboços, como foi o caso de Antonio Pisanello ${ }^{77}$ em desenhos como Macaco, 1430, e Estudo de Cavalo, 1435 [llustração 1.11].

\footnotetext{
${ }_{77}^{76}$ Idem, ibidem.

77 Segundo Argan, "Antonio Pisanello (c. 1395-1455), pisano de nascimento" possui todos os interesses e as curiosidades do humanista: é estudioso do antigo, indagador perspicaz da natureza, técnico versátil (pintor e medalhista). E é o predileto das cortes senhoriais, chamado a Milão, Verona, Mântua, Rimini, Ferrara, Roma e Nápoles; para o seu enorme sucesso contribui o fato de que a sua cultura é moderna sem ser revolucionária, renova as formas sem subverter as estruturas. "Pisanello foi aluno de Gentile de Fabriano e reconhece no desenho, assim como Jacopo Bellini, outro aluno de Gentile, "(...) a última, a mais refinada e intelectual das técnicas artísticas". Ver ARGAN, Giulio Carlo. op. cit. vol. 2 (De Giotto a Leonardo) p. 92.
} 

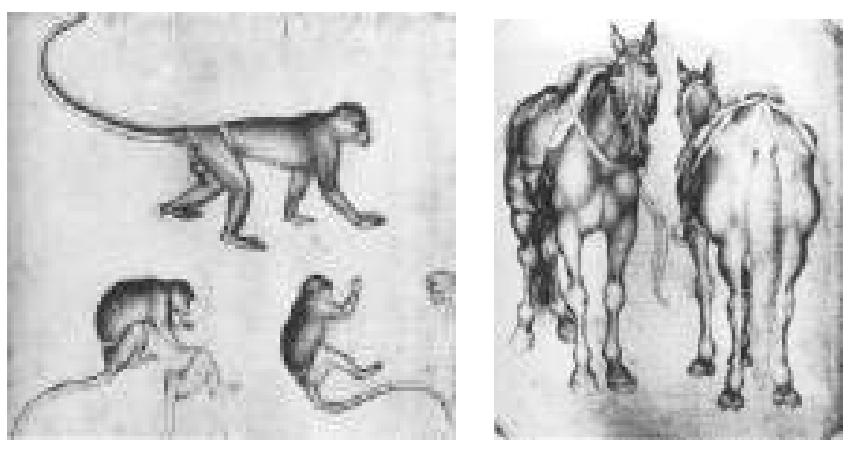

Ilustração 1.11: Antonio Pisanello. Macaco, c.1430. Desenho. Museu do Louvre, Paris (à esquerda) e Estudo de cavalo, 1433-38. Caneta sobre papel. 29 x 16,5 cm. Museu do Louvre (à direita).

A partir desses desenhos entende-se que o detalhamento não se limita a aspectos como a pelagem dos animais, mas que se estende à maneira como eles se movimentam.

Os séculos XV a XVI - denominados de Quattrocento e Cinquecento ${ }^{78}$ que compreendem o estabelecimento e consolidação do Renascimento terão como destaque, principalmente, a introdução da perspectiva. Isso se dará primeiramente a partir das noções de arquitetura empregadas por Fillippo Brunelleschi e, posteriormente, aperfeiçoadas por Alberti —, o estudo da anatomia humana e a concepção humanista ao invés de teocentrista: Deus deixa de ser visto como o centro do Universo e volta-se então a atenção para o homem.

A partir da perspectiva ${ }^{79}$, torna-se possível aos pintores aumentarem o realismo de suas obras, conferindo-lhes uma efetiva ilusão de tridimensionalidade. A isso se somará a manipulação de luz e sombra que será

\footnotetext{
78 "Quattrocento: Termo italiano designativo do século XV. Para os outros séculos são empregados: Dugento ou Duocento (século XIII); Trecento (século XIV); Cinquecento (século XVI); Seicento (século XVII); Settecento (século XVIII); Ottocento (século XIX) e Novecento (século XX). " Ver Dicionário Oxford de Arte (São Paulo: Martins Fontes, 1996 ), p. 432.

${ }_{79}$ Segundo ARGAN, a "perspectiva dá o verdadeiro espaço, isto é, uma realidade da qual é eliminado tudo o que é casual, irrelevante ou contraditório (...) A perspectiva constrói racionalmente a representação da realidade humana: pois que o mundo é natureza e humanidade, perspectiva e história se integram e, juntas, formam uma concepção unitária de mundo". Ver ARGAN, op. cit., vol. 2 (De Giotto a Leonardo), p. 132.
} 
aperfeiçoada com as técnicas de chiaroscuro e sfummato desenvolvidas por Leonardo da Vinci.

\section{Segundo Argan:}

O interesse que os artistas do Quatrocentos têm pela ação e, por conseqüência, pelo movimento explica por que as proporções não se constituem em cânones fixos: desde o princípio o interesse se atém ao corpo em movimento, à possibilidade de que o gesto fixado na imagem implique e, de algum modo sugira, o antes e o depois daquele ato. Do estudo de proporção do corpo em movimento chega-se ao estudo da anatomia, como aparato motor da pessoa e princípio ativo de sua relação com o mundo. Perspectiva e proporções entram já no grandioso programa de recuperação cultural a que os artistas do Quatrocentos se propõem: a renovatio ou renascimento do "antigo"

O pintor florentino Paolo Uccello ${ }^{81}$ apresenta tentativas de empregar a perspectiva na pintura A Batalha de São Romano (c. 1450) [llustração 1.12].

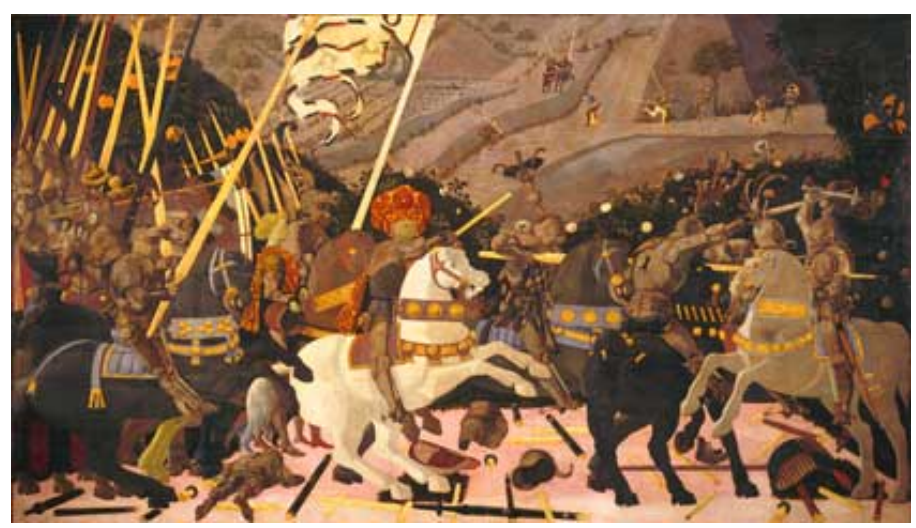

Ilustração 1.12: A Batalha de São Romano. Paolo Ucello, c.1450. Acervo National Gallery.

Um dos detalhes que mais chamam a atenção a esse respeito é o soldado caído "de bruços" no chão, representado em escorço, embora,

\footnotetext{
${ }^{80}$ Idem, ibidem, p. 135.

${ }^{81}$ Ucello tanto se impressionou com a descoberta da perspectiva "que passava dias e noites desenhando objetos em escorço e criando para si mesmo novos problemas a solucionar”. Ver GOMBRICH, E. H. op. cit. p. 190.
} 
proporcionalmente às outras figuras humanas tal soldado seja pequeno. Com relação à questão do movimento, observe-se a rigidez na representação do movimento dos cavalos empinando.

O pintor, cientista, estudioso de anatomia, botânica, vôo das aves, engenharia e música, Leonardo da $\mathrm{Vinci}^{82}$, iria realizar o Estudo para estátua eqüestre de Francesco Sforza ${ }^{83}$ [Ilustração 1.13], quase quarenta anos depois da pintura A Batalha de São Romano, de Ucello, e mais de cinqüenta do Estudo de Cavalo, de Pisanello.

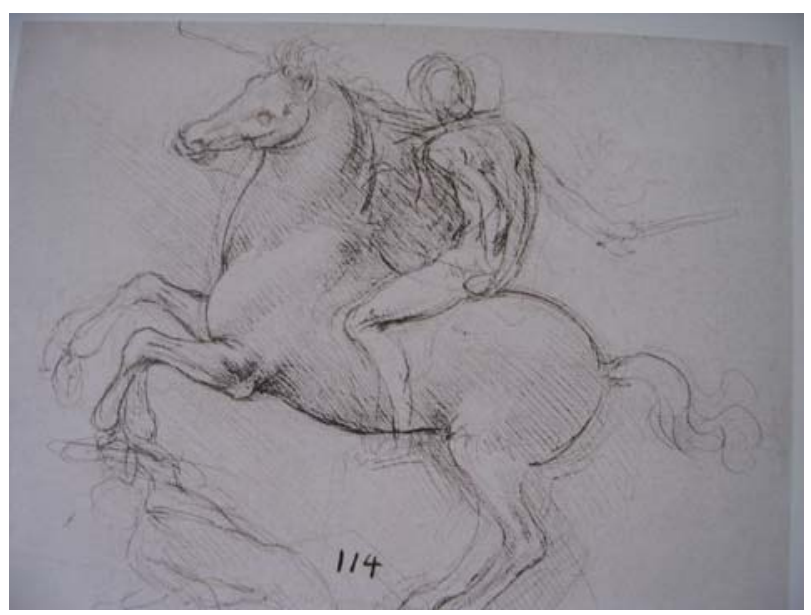

Ilustração 1.13: Leonardo da Vinci. Estudo para estátua eqüestre de Francesco Sforza, (c.1483-8). Royal Library, castelo de Windsor.

Ao contrário de Ucello, Leonardo da Vinci consegue transmitir a idéia do movimento de um cavalo empinando: note-se os vários registros das pernas frontais do cavalo, na tentativa de registrar as fases de seu movimento

\footnotetext{
${ }^{82}$ Segundo Argan, para Leonardo da Vinci a arte "é um dos tantos modos de indagação, experiência, conhecimento; mas, em certo sentido, prevalecente sobre outros porque o desenho é 'coisa mental', processo intelectual e, como tal, instrumento de indagação válido para todas as disciplinas. Grande parte das suas pesquisas e descobertas, da anatomia à mecânica, da botânica à cosmologia, é expressa e comunicada por meio do desenho, que efetivamente trai sempre a febre da pesquisa, o questionamento da hipótese, a curiosidade da verificação. Mas exatamente porque Leonardo é o primeiro a conduzir pesquisas científicas com finalidade e metodologia específicas, é também o primeiro a separar a arte da ciência, pela própria e específica finalidade e metodologia. Não por acaso a sua coletânea de notas sobre a pintura forma um tratado em si, bem distinto dos tratados que concebe para outras disciplinas que ocupam a sua mente." Ver ARGAN, Giulio Carlo, op. cit. vol.2 (De Giotto a Leonardo), p.375.

${ }^{83} \mathrm{Em} 1499$, quando franceses ocuparam Milão, o molde de gesso da estátua foi destruído. Por este motivo, ela não foi fundida em bronze. Idem, ibidem, p. 375.
} 
enquanto o animal empina. Além disso, o cavalo de Da Vinci parece mais real que o de Ucello.

Com relação ao Estudo de Cavalo, de Pisanello, o Estudo para estátua eqüestre de Francesco Sforza, de Da Vinci, apresenta a evolução da observação de determinado movimento do cavalo pelo artista de modo a conseguir registra-lo satisfatoriamente.

Outro artista do Renascimento, Rafael Sanzio ${ }^{84}$, realiza estudos do movimento de um cavalo, o qual resulta nas pinturas de São Jorge e o Dragão $^{85}$ [llustração 1.14], realizadas entre 1504 e 1506. A representação do movimento do cavalo pode ter sido baseada no estudo anterior de Da Vinci para a estátua eqüestre de Francesco Sforza, ou em estudos como o do afresco da Batalha de Anghiari ${ }^{86}$, também realizados por Da Vinci.
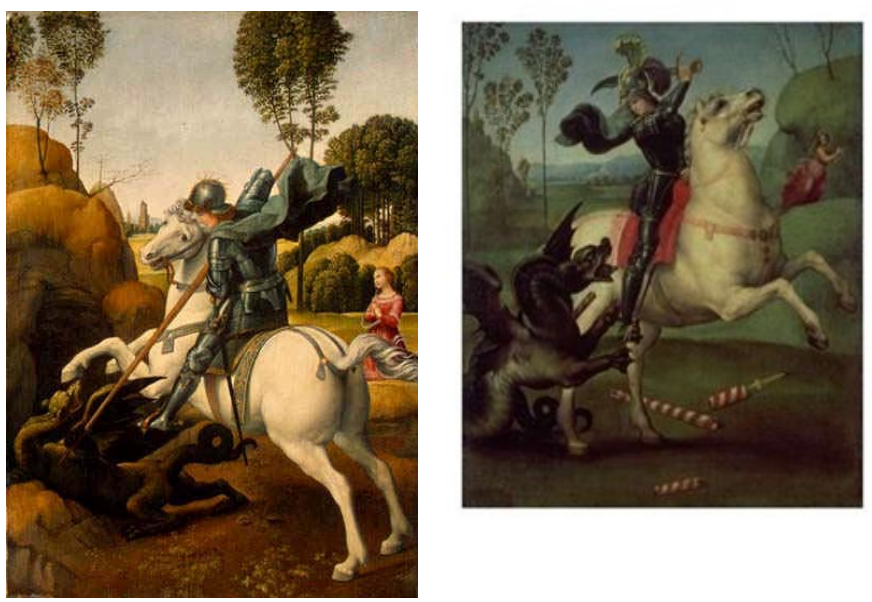

Ilustração 1.14: Rafael Sanzio. São Jorge e o Dragão, 1504 a 1506.

\footnotetext{
${ }^{84}$ Outras obras de Rafael poderiam ser lembradas como Escola de Atenas (1509-1510), A Ninfa Galatéia (1514) e São Miguel derrotando o Demônio (1520). Porém, neste estudo optou-se por mostrar as pinturas que Rafael fez de "São Jorge e o Dragão" para o contexto da representação da pintura eqüestre.

${ }^{85}$ A lenda de São Jorge e o Dragão foi amplamente representada na arte desde as civilizações antigas. Artistas como Paolo Uccello, Tintoretto e Cândido Portinari são alguns dos que pintaram essa lenda.

86"Quando Rafael chegou a Florença, deparou com um estimulante desafio. Leonardo e Miguel Ângelo, um mais velho trinta anos e outro oito anos, estavam criando novos padrões artísticos com que ninguém jamais sonhara. Outros artistas jovens poderiam ser desencorajados pela reputação desses dois gigantes. Rafael não. Estava decidido a aprender". Ver GOMBRICH, E. H. op. cit. p. 238. Rafael fez outros estudos de cavalos, como no desenho "Cavaleiros", pertencente ao Acervo da Galeria Ufizzi, realizado em 1503, quando Rafael viajava pela Itália. Nesse esboço, Rafael representa os cavalos e soldados em escorço. Esse período coincide com o momento em que Leonardo da Vinci e Michelangelo trabalhavam em paredes opostas da Sala do Conselho do Palácio de la Signoria, realizando os esboços de "A Batalha de Anghiari" e "A Batalha de Cascina", respectivamente.
} 
Em 1495, Da Vinci daria início a um de seus mais célebres murais: $A$ Última Ceia [llustração 1.15].

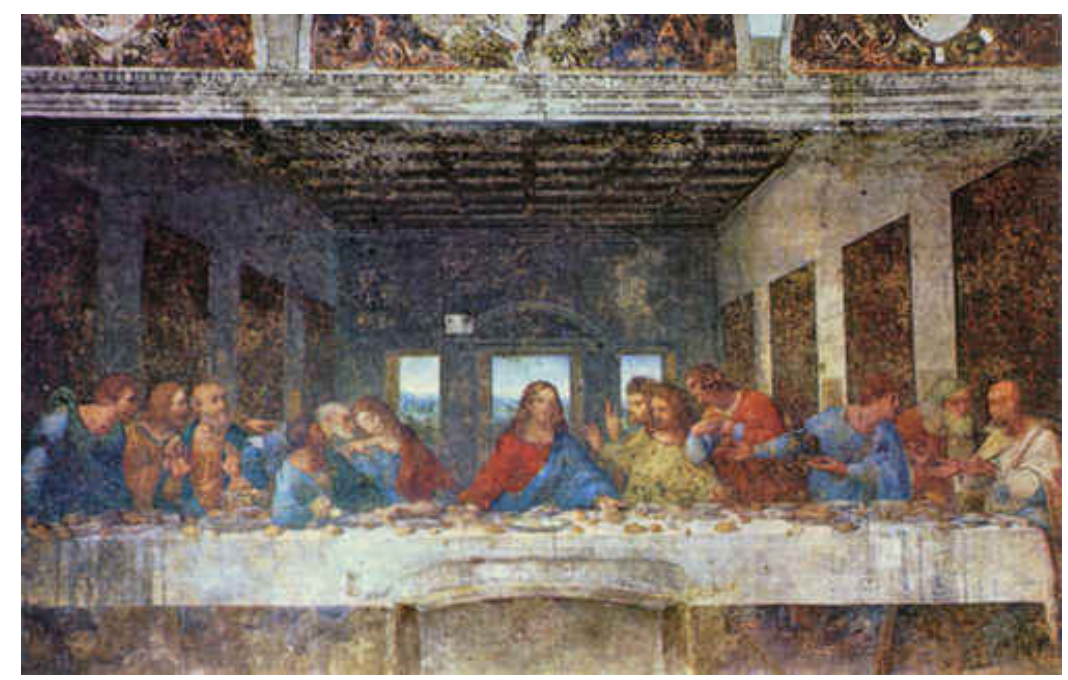

Ilustração 1.15: Leonardo da Vinci. A Última Ceia, 1495-1498. Mural no Refeitório do Mosteiro de Santa Maria delle Grazie, Milão.

Nessa obra se perceberá com clareza os efeitos da perspectiva sobre o registro do movimento.

As figuras do Cristo e dos doze apóstolos estão todas inseridas em "linhas de fuga" e, portanto, representadas em perspectiva.

Esse fato concede ilusão de tridimensionalidade às figuras, e nos transmite a sensação de que se movimentam de maneira autêntica, como se tivessem sido flagradas naquela situação (observe-se, por exemplo, o registro do movimento do apóstolo à direita do Cristo que se afasta para trás com as mãos abertas). 
O final do século XVI, marca a transição do Renascimento para o Barroco que irá florescer no século XVII. Tal período ficaria conhecido por "Maneirismo", devido a atitude de jovens pintores de imitar a maneira de fazer arte de artistas renascentistas como Michelangelo, Rafael, Ticiano e Leonardo da Vinci:

Por volta de 1520 , todos os amantes de arte nas cidades italianas pareciam concordar em que a pintura atingira o auge da perfeição. Homens como Miguel Ângelo e Rafael, Ticiano e Leonardo, tinham realmente feito tudo o que gerações anteriores haviam tentado fazer. Nenhum problema de desenho parecia ser insuperável para eles, nenhum tema complicado demais. Tinham mostrado como combinar beleza e harmonia com inexcedível correção, e - conforme se dizia - tinham até superado as mais célebres estátuas da antiguidade grega e romana ${ }^{87}$.

Tintoretto (Jacopo Robusti) será um dos artistas desse momento. A questão da representação do movimento do corpo humano, apresentando as figuras em escorço, estará presente na tentativa de imitar os mestres Renascentistas, como é possível observar em nas obras A Ceia em Emmaus (1542-43) e A Deposição de Cristo (1563) [llustração 1.16], por exemplo.

\footnotetext{
${ }^{87}$ Ver GOMBRICH, E. H. op. cit. p. 277.
} 

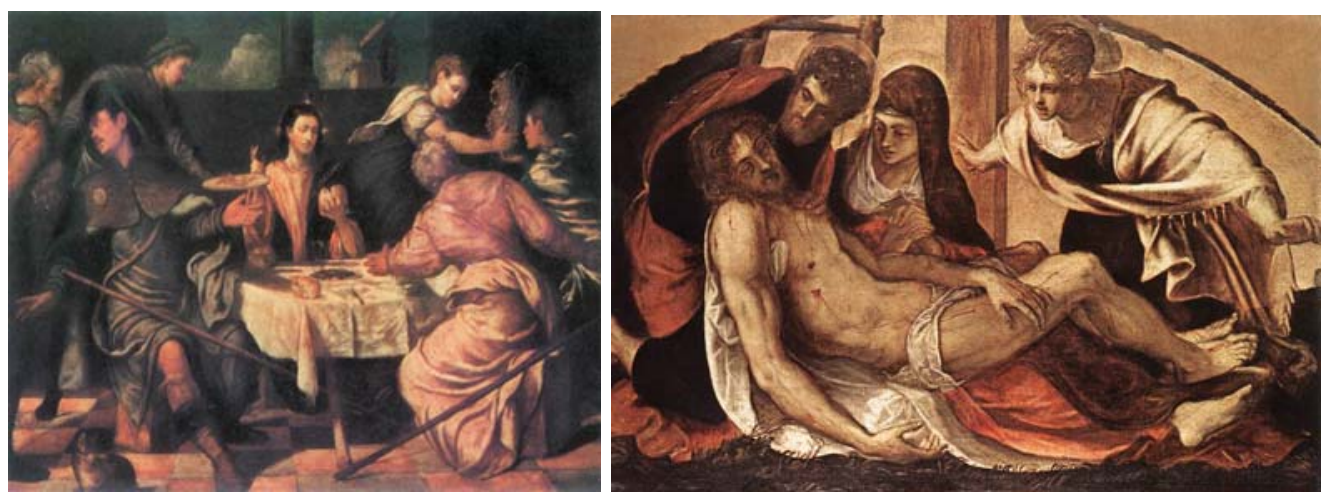

Ilustração 1.16: Tintoretto. A Ceia em Emmaus, 1542-43. Acervo do Museu de Belas Artes de Budapeste (à esquerda) e $A$ Deposição de Cristo, 1563. Acervo da Pinacoteca de Brera, Milão (à direita). Observese, nesta última obra, especialmente, a torsão do corpo de Cristo e a representação dos músculos peitorais, braçais e das pernas.

A questão da representação do movimento já teria sido superada no Renascimento. A partir do século XVII a noção dessa representação evolui de modo que no século XVIII o desejo do pintor será o de "capturar o instante, de tornar sensível um momento fugidio ${ }^{88 "}$.

No contexto do século XVIII, em certas obras de Rubens, Rembrandt, Jacques-Louis David, Jean-Honoré Fragonard e Thomas Gainsborough será percebido o interesse em captar o momento fugidio.

O estudioso Jean Starobinski destaca em seu livro $A$ Invenção da Liberdade, a seguinte consideração de Diderot, que bem esclarece a questão da captação do instante: "O pintor tem apenas um instante e não lhe é permitido abarcar dois instantes como não lhe é permitido abarcar duas ações $^{89 ", .}$

A partir disso Starobinski reflete, que para conseguir tal captação "o pincel e o óleo são meios por demais lentos: é o creiom, é o guache, o desenho

\footnotetext{
${ }^{88}$ STAROBINSKI, Jean. A Invenção da Liberdade, 1700-1789. São Paulo: Editora Unesp, 1994 (Coleção Studium), p.

${ }^{19}$ Idem, ibidem.
} 
a carvão, a aquarela, manejados com mão ágil, que poderão rivalizar em velocidade com o objeto que foge ${ }^{90 "}$.

Dentro dessa perspectiva pode ser inserida a obra Jovem de pé, de Jean-Honoré Fragonard [llustração 1.17], por exemplo.

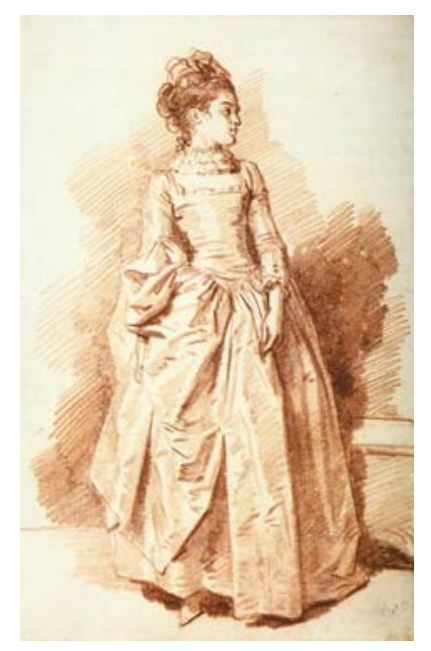

Ilustração 1.17: Jean-Honoré Fragonard. Jovem de pé, c. 1775-85, Carvão Vermelho. Rijksmuseum, Amsterdã.

Para encerrar a questão da representação do movimento na Arte, apresenta-se como imagem final a Derby de Epson (1821), de Theodore Gericault [llustração 1.18], que nos mostra novamente a representação da pintura eqüestre, e, portanto, a captação do movimento animal.

Gericault representa os cavalos correndo com as quatro patas no ar, situação, que mais tarde, seria revista por meio dos experimentos de Eadweard Muybridge com a cronofotografia.

\footnotetext{
${ }^{90}$ Idem. ibidem.
} 


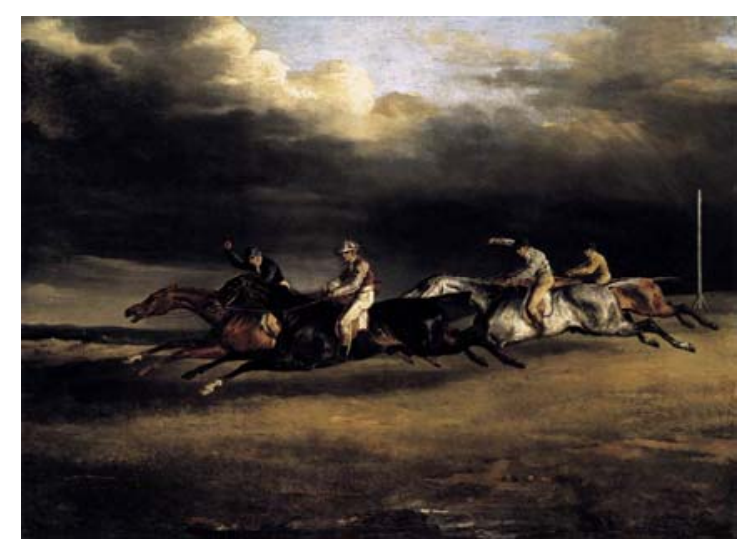

Ilustração 1.18: Theodore Gericault. Derby de Epson, 1821, Óleo sobre tela. Acervo do Museu do Louvre, Paris.

\section{A imobilidade da pose do retrato fotográfico e a espontaneidade do flagrante ${ }^{91}$}

(...) o que funda a natureza da Fotografia é a pose; mesmo no tempo de um milionésimo de segundo (a gota de leite de H. D. Edgerton), sempre houve pose, pois a pose não é aqui uma atitude do alvo, nem mesmo uma técnica do Operator, mas o termo de uma "intenção" de leitura: ao olhar uma foto, incluo fatalmente em meu olhar o pensamento desse instante, por mais breve que seja, no qual uma coisa real se encontrou imóvel diante do olho.

Roland Barthes. A Câmara Clara (Rio de Janeiro: Ed. Nova Fronteira, 1984, p.117)

Com a invenção da fotografia a necessidade de registrar o movimento surge em paralelo com a tradição do retrato, embora não ao mesmo tempo, uma vez que o registro do movimento dependerá do aprimoramento da técnica fotográfica. Essas possibilidades se configurarão em dois cânones opostos: por um lado, o retrato fotográfico, caracterizado pela imobilidade da pose e, por

\footnotetext{
${ }^{91}$ Aqui não se pretende fazer um estudo aprofundado sobre o retrato fotográfico, apresentar um histórico detalhado sobre as suas categorias (retrato honorífico e disciplinar) e usos ou debater a utilização da fotografia como base para a produção de retratos na pintura (acredita-se que Ingres foi provavelmente um dos primeiros pintores que utilizaram o daguerreótipo na execução de retratos. A esse respeito, Eugène Mirecourt, relacionou em 1855 os retratos de Ingres à fotografia de Nadar quem seria o único fotógrafo ao qual Ingres enviava os seus clientes que queriam ser retratados com grande verossimilhança. Ver SCHARF, Aaron. Arte y fotografia. Madri: Alianza Forma, 1994, p. 52). Neste tópico tem-se a intenção de produzir um breve panorama sobre o papel do retrato fotográfico no século XIX como cânone oposto ao instantâneo.
} 
outro, o instantâneo, motivado pela busca dos fotógrafos em captar o movimento na fotografia.

A tradição do retrato fotográfico começa a se estabelecer pautando-se na tipologia do pictórico realizado no século $X V$, quando o gênero retrato se emancipa na pintura.

Segundo Annateresa Fabris, no "século XV, da conjunção da generalização florentina com o detalhamento flamengo surge um modelo de retrato de tendência internacional, que acaba logo adquirindo um aspecto $\operatorname{serial}(\ldots)^{92}$.

Para exemplificar tal tipologia, Fabris cita um um texto de Galienne Francastel $^{93}$ :

\begin{abstract}
Apresentado sobre um fundo neutro, é tomado de três quartos ou de perfil, nunca de frente; aparece cortado um pouco abaixo dos ombros e confere muita importância ao penteado. A cara é realista, sem excessiva abundância de detalhes, mas apresenta, em contrapartida, vários relevos sobre os quais é jogada uma hábil iluminação.
\end{abstract}

De acordo com a historiadora, o retrato fotográfico absorveria igualmente elementos do retrato renascentista no que diz respeito ao fundo do retrato: no renascentista "o fundo neutro permitia realçar o indivíduo", conferindo-lhe "um ar austero ${ }^{94 ”}$. A partir disso, será constituída a idéia de que o homem não seria completo "se estivesse dissociado do âmbito de sua vida cotidiana" e para demonstrar isso no retrato, surge "um fundo animado por imagens naturais exteriores ou por representações de interiores", de modo que "o entorno

\footnotetext{
${ }^{92}$ FABRIS, Annateresa. Identidades Virtuais - uma leitura do retrato fotográfico. Belo Horizonte: Editora UFMG, 2004. p. 26.

${ }^{93}$ Idem. ibidem. Fabris refere-se ao texto Hacia la libertad del retrato: siglos XVI y XV, de Galienne Francastel (In: FRANCASTEL, Galienne\&Pierre. El retrato. Madrid, Cátedra, 1995).

${ }^{94}$ FABRIS, Annateresa, op. cit. p. 26.
} 
integra-se com os demais atributos que caracterizam a personalidade do modelo, sem chegar a ter uma existência independente ${ }^{95 "}$.

\section{$\S \S \S \S$}

Na segunda metade do século XIX, posar para um retrato se tornaria "sinônimo de 'postura estudada', 'artificial'”, a partir do novo sentido conferido pela sociedade francesa ao ato de posar ${ }^{96}$, situação que estaria ligada à idéia de teatralidade e encenação.

Considerada símbolo da fotografia no século XIX, a pose pressupunha todo um ritual ${ }^{97}$. O retrato posado era realizado no "salão de pose", ambientado por cenários e figurinos, além de conter objetos para manter o retratado imóvel $^{98}$ durante os longos períodos de exposição - como uma espécie de forquilha para "apoiar a cabeça e fixar o corpo".

Segundo Turazzi, "na literatura dedicada ao ensino e à difusão da fotografia publicada ao longo do século XIX, a preocupação com a pose é recorrente e ocupa lugar de destaque ${ }^{100 "}$.

\footnotetext{
${ }^{95} \mathrm{No}$ contexto desse parágrafo, entende-se o retrato tanto realizado por meio da daguerreótipia observando-se "o rápido surgimento de elementos decorativos nos primeiros daguerreótipos" como os primeiros retratos fotográficos, estes aplicados a noção de história no sentido dado por Baudelaire. Ver FABRIS, Annateresa, op. cit. p. 26.

${ }^{96}$ Ver TURAZZI, Maria Inez. Poses e Trejeitos - A fotografia e as exposições na era do espetáculo (1839-1889). Rio de Janeiro: FUNARTE/Rocco, 1995, p. 14.

${ }_{97}$ Idem,ibidem, p.13. "A pose é o próprio símbolo da fotografia do século XIX, atravessando toda a sua história como elo de ligação entre as imagens obtidas, os recursos tecnológicos existentes e os agentes sociais envolvidos(...) Ao longo da segunda metade do século XIX pode-se mesmo traçar um percurso na história da fotografia que vai da pose ao instantâneo, da imobilidade ao movimento".

${ }_{98}$ A respeito da imobilidade, ver o seguinte trecho retirado da obra La fotografia como documento social (Barcelona: Gustavo Gilli, 1976), de Gisele Freund, citado na obra de Turazzi: "Em 1840 os primeiros 'pacientes' da fotografia tinham que sentar-se justo ao lado da janela, expostos a um sol ardente que thes ensopava de suor e deviam suportar durante vários minutos os sofrimentos da imobilidade". (Ver TURAZZI, Maria Inez. Op. cit. p. 16).

${ }_{99}$ Idem. ibidem. Segundo Maria Inez Turazzi, os aparelhos de pose ficariam relegados ao esquecimento, no final do século XIX. Apesar disso, a pose continuou ainda a fazer parte do ritual simbólico construído em torno do retrato fotográfico. Nas palavras da estudiosa, "os aparelhos de pose tiveram larga difusão nas primeiras décadas do retrato fotográfico, mesmo quando o tempo de exposição já se havia reduzido bastante". A esse respeito, Turazzi cita a obra La photographie en Amérique, de Alphonse Liébert, publicada na década 1860, na qual Liébert apresentava "aparelhos 'simplificados' para pose, pelo 'sistema americano', com tamanhos variados para crianças e adultos". Ainda de acordo com a estudiosa, "Liébert sugeria que esses aparelhos teriam grande utilidade para as pessoas que não estavam 'acostumadas' a posar facilitando em tais casos a habilidade requerida ao operador da máquina fotográfica”.

${ }^{100}$ Ver TURAZZI, Maria Inez, op. cit, p. 14.
} 
Encontravam-se nessa literatura alguns dos principais elementos que envolviam a pose como o salão de pose, a câmara fotográfica, o papel do fotógrafo, do cliente e os acessórios utilizados para manter a imobilidade do retratado.

Em obras como Dissertations historiques, artistiques et scientifiques sur la photographie, de Alexandre Ken, publicada em 1864, e L'atelier du photographe, de H. P. Robinson, de 1888, respectivamente, algumas dessas questões serão observadas.

Alexandre Ken irá abordar, fundamentalmente, a questão da conduta do "modelo" no atelier do fotógrafo, antes de entrar no salão de pose:

No atelier do fotógrafo, o modelo posa apenas meio minuto diante do instrumento. É preciso que antes de entrar no salão de pose, ele tenha esquecido na sala de espera qualquer preocupação exterior: que ali folheando os álbuns, examinando os retratos expostos, indagando sobre o seu valor artístico e o caráter de cada um deles, possa apreciar e captar a pose e a expressão que melhor lhe convenha e que alguns conselhos do artista lhe ajudarão a assumir. Tudo deve ser feito para distrair o visitante e dar ao seu semblante uma expressão de calma e felicidade, para fazer nascer em seu espírito idéias agradáveis, risonhas que, clareando os seus traços com um doce sorriso, façam desaparecer aquela expressão séria que a grande maioria tem tendência a assumir, e que, sendo a que mais se exagera, dá geralmente à fisionomia um ar de sofrimento, de contração ou de tédio ${ }^{101}$.

H.P. Robison comenta os papéis do "fotógrafo" e do "cliente": ao fotógrafo cabe definir a postura do cliente para o retrato, os tempos de pose e a ambientação do salão de pose. E ao cliente, passar a noção de como gostaria

\footnotetext{
${ }^{101}$ Esse trecho foi originalmente citado em TURAZZI, Maria Inez. op. cit. p. 15. Note-se que Alexandre Ken refere-se ao trabalho de direção do fotógrafo como "conselho do artista". Desse modo, entendo que o trabalho de realização de um retrato fotográfico era considerado artístico e, portanto, o fotógrafo era visto como um artista.
} 
de ser retratado e confiar na competência do fotógrafo para o sucesso desse empreendimento:

É inútil dizer aos fotógrafos que a metade de seus clientes imagina que sabe como deve posar e é igualmente desnecessário acrescentar que esses modelos são os indivíduos mais detestáveis ${ }^{102}$.

Todo esse ritual em torno do retrato fotográfico, denota o sentido social de ser retratado no século XIX, fazendo com que a pose e seu ritual simbólico fossem "uma exigência de cunho social mais do que uma imposição técnica ${ }^{103 " . ~}$ Isto é, os trejeitos ${ }^{104}$, ou gestos, dos retratados, as vestimentas e o cenário, caracterizavam uma simbologia acerca da classe social burguesa, ou, nos dizeres de Annateresa Fabris, constituiriam "um brasão burguês ${ }^{105 " . ~}$

A invenção do carte de visite, por André Adolphe Eugène Disderi, na década de 1850, será uma peça importante para a análise da função social do retrato na sociedade oitocentista como observam Annateresa Fabris e Maria Inez Turazzi.

Segundo Fabris:

O "efeito Disderi" não pode ser dissociado de uma análise da função social do retrato na sociedade oitocentista. Se no século XIX, o retrato pictórico começa a ser questionado como gênero em função das transformações profundas pelas quais passa a arte moderna, não se pode, porém, esquecer que esse mesmo século conhece um desenvolvimento extraordinário da representação e da auto-representação do indivíduo em conseqüência da crescente necessidade de personalização da burguesia. Sinal de

\footnotetext{
${ }^{102}$ Esse trecho foi originalmente citado em TURAZZI, Maria Inez. op. cit. p. 14.

${ }^{103}$ Ver TURAZZI, Maria Inez. op. cit. p. 15.

104 Idem.ibidem. p. 17.

${ }^{105}$ Ver FABRIS, Annateresa. op. cit p. 30
} 
distinção somente acessível à aristocracia, o retrato começa a ser cultivado pela burguesia durante os reinados de Luís XV e Luís XVI de uma maneira peculiar, que respondia sobretudo às suas possibilidades econômicas. Embora se inspire nas convenções do retrato aristocrático, o retrato burguês não pode, porém, adotar seu formato $(\ldots)^{106}$.

\section{Para Turazzi:}

(...) nenhum outro nome ligado à história da fotografia no século XIX encarnou com tanta propriedade esse "condenável" espírito burguês como o fotógrafo Adolphe Disderi, responsável pela transformação do retrato fotográfico em uma mercadoria realmente popular. A introdução do formato carte de visite $($ c. 6 × 9,5 cm), patenteado por Disderi em 1854, reduziu radicalmente o preço final de uma fotografia, graças a possibilidade de multiplicação das cópias obtidas a partir de um único negativo, como também pelo barateamento resultante da diminuição do tempo e do trabalho de manipulação em laboratório embutidos no custo final de cada retrato ${ }^{107}$.

Porém, se a pose e seu ritual simbólico denotam um caráter de exigência social, mais do que uma imposição técnica, o inverso ocorre com relação ao instantâneo. Esta categoria só se consolidará a partir de uma evolução técnica, com a qual será possível incorporar os ritmos da vida social.

Essa "evolução técnica" está diretamente ligada à questão da apreensão do tempo na fotografia:

(...) do daguerreótipo ao instantâneo, a diminuição do tempo de obtenção das imagens fotográficas e a percepção desse mesmo tempo na apreensão da realidade, a partir dessas imagens, inscreviam-se no movimento mais geral de aceleração dos ritmos que

\footnotetext{
${ }^{106}$ Idem, ibidem, p. 28 e 29

${ }^{107}$ Ver TURAZZI, op. cit. p 60.
} 
compassavam a vida cotidiana na segunda metade do século XIX, reforçando a construção de uma certa leitura do tempo e do espaço e, por extensão, da própria história, em sintonia com a lógica linear e positiva das teorias do progresso então em $\operatorname{voga}^{108}$

Antes de se encerrar esse tópico cabe retomar a idéia de teatralidade e encenação que nasce junto com o fato de posar para um retrato fotográfico. 0 retratado assumirá um papel a fim de oferecer determinada imagem de $\mathrm{si}^{109}$.

Esse mecanismo de "encenar" estará por trás da noção de pseudoflagrante, mas com a intenção de mostrar uma ação posada como se fosse espontânea (flagrada).

\title{
$\underline{\text { A instantaneidade e o pseudoflagrante nos primórdios da fotografia: do registro }}$
}

\section{$\underline{\text { de objetos à fotografia de rua }}$}

A tentativa de congelar o movimento por meio da fotografia no século XIX está diretamente ligada à busca pela instantaneidade que se manifesta em experimentações de diversos fotógrafos:

\begin{abstract}
Da mesma maneira que os fotógrafos tratavam constantemente de aperfeiçoar o colorido natural, também esperavam resolver o problema de registrar objetos em movimento. Em meio ao entusiasmo que produziu o surgimento da primeira câmara fotográfica, as aspirações dos novos fotógrafos iam muito além de suas possibilidades $(\ldots)^{110}$
\end{abstract}

\footnotetext{
${ }^{108}$ Idem. Ibidem, p. 30.

${ }^{109}$ Posar significa "colocar-se em pose", o que acarreta "mostrar-se em uma postura que não é natural". Ver BORDIEU, Pierre. La definición social de la fotografia In: BORDIEU, Pierre (org.) La fotografía: un arte intermédio. México: Editorial Nueva Imagem, 1979.

${ }^{110}$ Tradução livre: "De la misma manera que los fotógrafos trataban constantemente de perfecionar el colorido natural, también esperaban llegar a resolver el problema de registrar objetos en movimiento. En medio del entusiasmo que
} 
Tais experimentos seriam realizados com objetos ${ }^{111}$, animais e seres humanos em movimento, desde o disco giratório captado por Talbot $^{112}$, em 1851, até os resultados obtidos pela cronofotografia ${ }^{113}$, empregada durante a década de 1870, com o objetivo de captar a locomoção desses três grupos e cujo principal expoente foi Eadweard Muybridge, quem aperfeiçoou esse princípio com a utilização da câmara fotográfica.

As imagens seqüenciadas do galope de cavalos, realizadas por Muybridge [llustração 1.19] viriam a elucidar a questão da representação do galope em pinturas eqüestres ou de batalha.

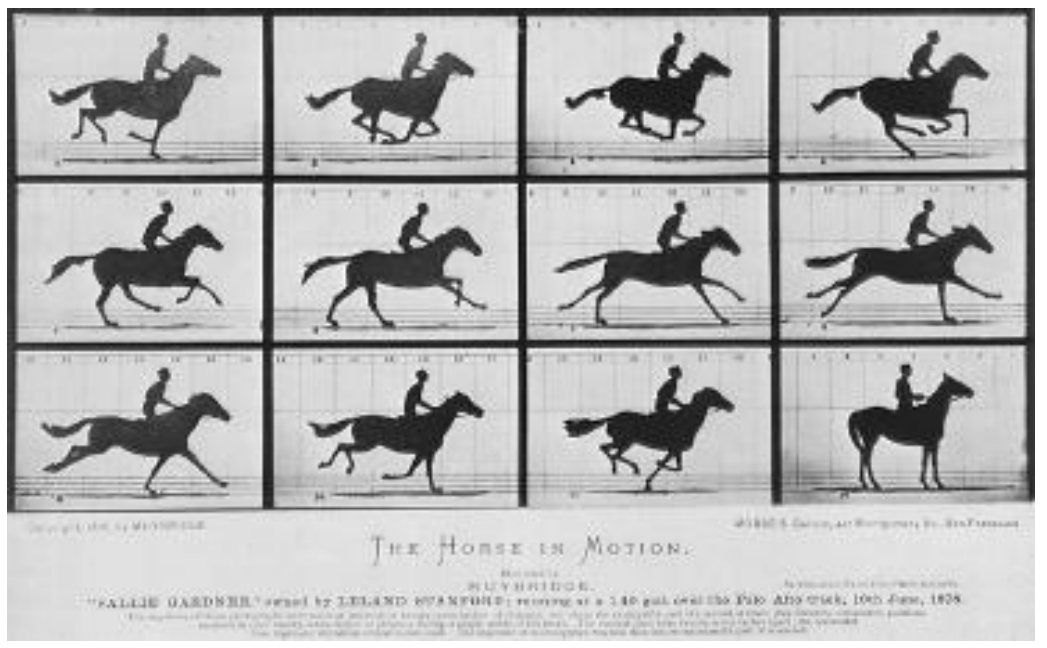

Ilustração 1.19: Eadweard Muybridge. Cavalo Galopando, 1878.

produjo la aparición de la primera câmara fotográfica, las aspiraciones de los nuevos fotógrafos subieron muy por encima de sus posibilidades" (SCHARF, Aaron. Arte y fotografia. Madri: Alianza Editorial, 1994, p. 191).

111“(...) até 1860, aproximadamente, quando a câmara fotográfica começou a fixar objetos em movimento em posturas que pareciam inconcebíves (...) não se podia dizer que a fotografia havia resolvido o primeiro problema da instantaneidade. (...) Outra fase muito importante começou nos anos setenta, quando foi possível tirar fotografias de objetos em movimento, mais rápido ainda(...) Ver SCHARF, Aaron. Degas y la imagen instantanea In: SCHARF, Aaron. op. cit., p. 191 (La instantanead)

${ }^{112}$ Ver Scharf, Aaron. Idem.ibidem. O autor se refere a Talbot como exemplo de realizador de alguns dos experimentos que obtiveram êxito, em captar com a câmara fotográfica objetos que se moviam com grande velocidade: "Em 1851, Talbot, com a ajuda da luz intensa de uma faísca elétrica, pode 'deter'" um disco em pleno e rápido movimento giratório com uma página do Times colada na superfície, de forma que se pudesse ler sem dificuldade o que estava escrito nela".

${ }^{113}$ A cronofotografia é uma "técnica fotográfica que consiste em registrar, em intervalos regulares e compassados, a locomoção de uma pessoa ou objeto móvel, empregada para estudar esse movimento. As primeiras experiências com a cronofotograifa foram realizadas na década de 1870 por Pierre Janssen (1824-1907), Étienne Marey (1830-1904) e Eadweard Muybridge (1839-1904). Antes mesmo de adotar as placas secas, este último chegou a obter imagens seqüenciadas do galope de um cavalo utilizando várias câmaras fotográficas colocadas em fileira e negativos de vidro de colódio úmido". Ver TURAZZI, Maria Inez. op. cit., p. 281. 
Será essa necessidade dos primeiros fotógrafos de congelar o movimento que irá gerar a idéia de flagrante fotográfico, propiciando o surgimento de seu falseamento - o pseudoflagrante. Como nos primórdios da fotografia, não se tinha condições técnicas para a real captação do instante, a fim de passar a idéia de registro de uma ação espontânea, falseava-se essa ação pela utilização do recurso da encenação e da pose.

Tal recurso será melhor observado no âmbito das primeiras fotografias de rua.

Historicamente a fotografia de rua começa a acontecer em meados do século XIX, primeiro na Europa, em Paris e Londres, e depois nos Estados Unidos, especialmente em Nova lorque ${ }^{114}$, como um desdobramento da "fotografia da cidade"115. Sua realização é deflagrada a partir da demanda gerada pelo crescimento urbano decorrente da industrialização:

Se a fotografia de paisagens deriva de um desenvolvimento na estética da pintura de paisagens, então a fotografia da cidade se funda na maneira como os espaços urbanos começam a ser percebidos no final do século XVIII e início do XIX. Temos de lembrar que a fotografia se estabeleceu em um período quando o crescimento da cidade e da indústria tinha provocado formidáveis peças literárias e de arte em resposta a crescente influência de áreas urbanas, especialmente em cidades como Londres, Paris, e Nova lorque. A fotografia toma seu lugar nesse processo, mas o faz em um senso ativo, simultaneamente respondendo a uma variedade e multiplicidade da vida urbana e a questões sobre como os espaços urbanos seriam percebidos e representados. Em síntese, a resposta da fotografia sempre foi em relação a complexidade visual da cidade tanto como imagem quanto como experiência ${ }^{116}$.

\footnotetext{
${ }^{114}$ Neste estudo observou-se que a fotografia de rua já começa a aparecer na França e Inglaterra em meados da década de 1840 e nos Estados Unidos, mais tarde, por volta do final dos anos 1880.

115 Termo usado pelo autor Graham Clarke no capitulo "The City in Photography" . In: The Photograph. Oxford University Press, 1997, págs. 75 a 99.

${ }^{116}$ Ver CLARKE, Graham, op. cit. p. 75.
} 
Segundo o estudioso Atílio José Avancini:

A vida na rua, o instantâneo, o olhar atento do 'flaneur', estimula em Paris, a criação de uma linguagem específica intitulada fototografia de rua ${ }^{117}$.

Ainda de acordo com o estudioso, a fotografia de rua:

“(...) tem o seu eixo no flagrante ao focar transeuntes pelas vias da cidade. $\mathrm{O}$ recurso técnico do instantâneo substitui a pose; surge a surpresa e o acaso fotográfico. A narratividade do cotidiano torna-se cerne(...) O fotógrafo de rua, ao identificar-se com a realidade urbana e humana, enfoca a dinâmica das pessoas tendo como pano de fundo o lugar público. A principal característica dessa atividade é o retrato do meio ambiente, mais especificamente, as ações do homem na imprevisibilidade de seu cotidiano ${ }^{118 " . ~}$

Dos diversos experimentos ${ }^{119}$ para a realização de fotografias de rua na França e Inglaterra, entre meados dos anos 1840 e final dos 1870, serão pontuados os resultados obtidos por três fotógrafos, emblemáticos na atuação no campo da fotografia nesses dois países: Charles Nègre (França), além de Willian Henry Fox Talbot e John Thomson (Inglaterra).

O pintor francês Charles Nègre passou a fotografar a partir de 1844, a fim de colecionar imagens que serviriam de base para suas pinturas, como a

117 AVANCINI, Atílio José. Em flagrante: Leitura de fotografias de rua do cotidiano da cidade de São Paulo nas duas primeiras décadas do século XX. Dissertação de mestrado apresentada à Escola de Comunicações e Artes da Universidade de São Paulo, São Paulo, 1999.

118 Idem. Ibidem.

119 O catálogo da exposição La Revolution de la photographie instantanée 1880-1900 nos aponta alguns casos de experimentos com a captação do instante na fotografia de rua por fotógrafos primordiais como Auguste-Adolphe Bertsch. Em 1855, Bertsch, experimentava uma técnica própria para o registro instantâneo, que teve como resultado a série de quatro miniaturas La Barrière Blanche. Tal série "forma um dos raros precedentes da estética desenvolvida pelo uso da gelatina-bromóleo(...)". O fotógrafo teria testado uma então nova preparação química, para realizar fotografias de quatro momentos diferentes de uma ação que acontecia na rua. Além disso, teria construído para a realização dessa série, um pequeno aparelho metálico de viagem com vários obturadores. (Ver Cahiers d'une exposition. Biblioteque nationale de France/Societé française de photographie La Révolution de la photographie instantanée 1880-1900). 
primeira série de calótipos que realizou de mercados ao ar livre a beira do rio Sena [llustração 1.20].

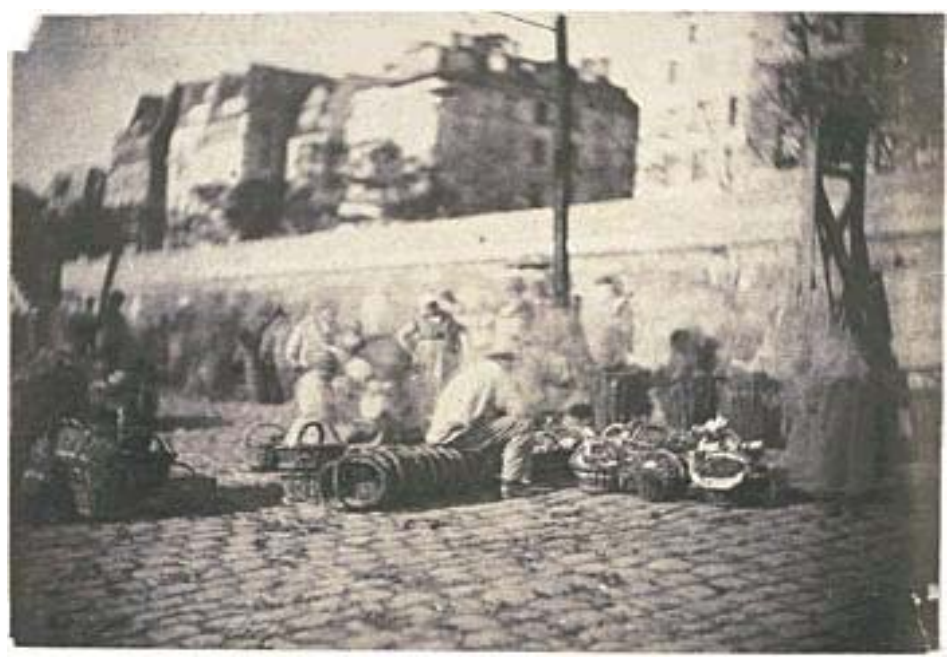

Ilustração 1.20: Charles Nègre. Cena de mercado no porto do Hotel de Ville - Paris. 1852. Prova em papel salgado. Doação de Mdme. Suzanne Winsberg ao Museu D'Orsay, 2002.

Como fotógrafo, Charles Nègre demonstraria grande interesse por cenas de rua, embora realizasse igualmente fotografias de arquitetura.

Nas fotografias de rua, a questão mais importante para Nègre era conseguir "parar a ação" (stopping action), noção que seria central no trabalho de futuras gerações de fotógrafos, como Henri Cartier-Bresson ${ }^{120}$.

Na busca por atingir esse objetivo, Nègre teria desenvolvido métodos para ganhar velocidade na captação da ação. O fotógrafo desenhou uma combinação de lentes mais rápidas que as disponíveis na época, e depois passou a utilizar a fotografia estereoscópica ${ }^{121}$ - técnica que será vista no decorrer deste estudo.

\footnotetext{
${ }^{120}$ Ver WESTERBECK, Colin \& MEYEROWITZ, Joel. Bystander: A History of Street Photography. Boston, Nova lorque e Londres: Bulfich Press Book, 2001. p. 68.

${ }^{121}$ Com a fotografia estereoscópica Nègre conseguiu captar alguns eventos espontâneos, como a queda de um cavalo na rua, em frente ao seu estúdio. Ver WESTERBECK, Colin \& MEYEROWITZ, Joel. Op. cit. p. 69 e 70.
} 
Além disso, Nègre realizou fotografias de rua nos diversos processos fotográficos da época, entre os quais o calótipo, o albúmen e o colódio úmido.

Para passar a idéia de cena espontânea, isto é, da captação do instante em determinada ação, Charles Nègre chegou a utilizar o recurso da encenação, obtendo então pseudoflagrantes.

Em fotografias de rua como Limpadores de Chaminé e Tocador de Orgão ${ }^{122}$ [llustração 1.21], realizadas por Nègre respectivamente em $1851 \mathrm{e}$ 1853, o fotógrafo teria solicitado aos retratados para encenar a ação ou posar para a foto. No caso da primeira, Charles Nègre teria pedido para que os limpadores de chaminés caminhassem na tentativa de congelar esse movimento. E na segunda, o tocador de órgão teria posado com a mão na maçaneta, para que Nègre pudesse passar a idéia de congelamento da ação de abrir a porta.
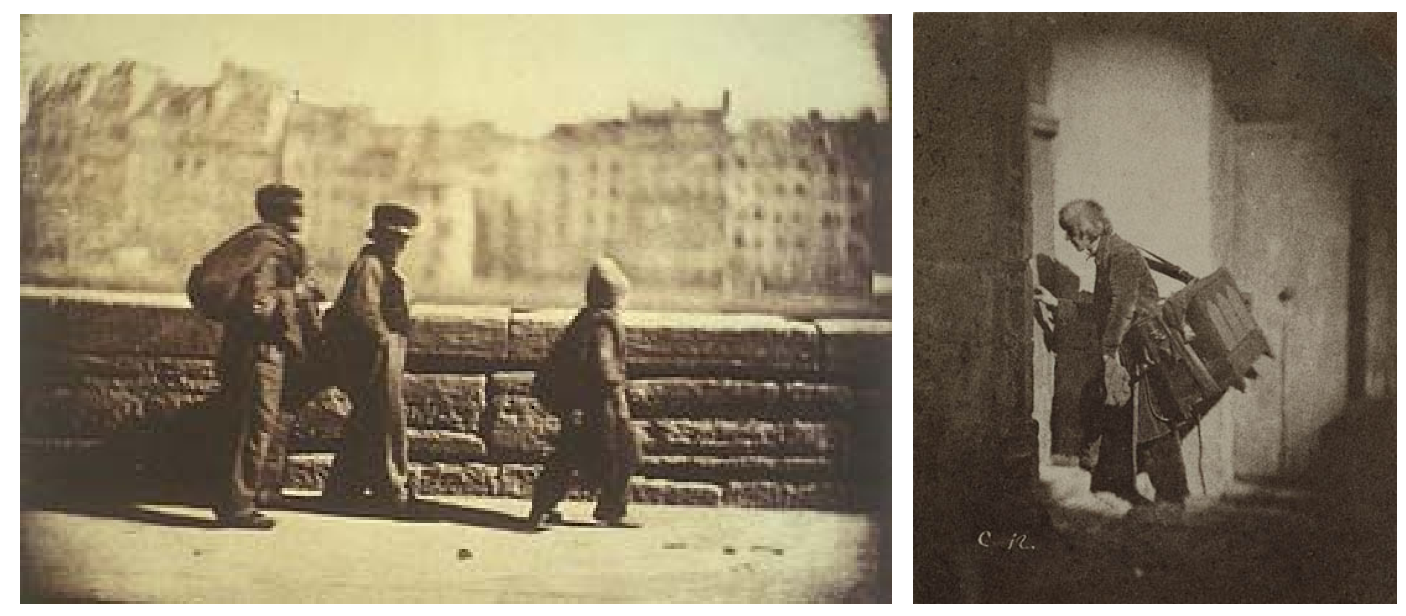

Ilustração 1.21: Charles Nègre. Limpadores de Chaminé, 1851. Papel albuminado (à esquerda) e Tocador de Órgão, 1853. Matriz-negativo (à direita).

\footnotetext{
${ }^{122}$ As fotografias de personagens de rua de Charles Négre seriam consideradas precursoras daquelas realizadas posteriormente por Jacob Riis e Eugène Atget. Ver WESTERBECK, Colin \& MEYEROWITZ, Joel., op. cit. p. 68.
} 
O inglês Willian Henry Fox Talbot, inventor do calótipo ${ }^{123}$, entre 1844 e 1846, lançou em seis fascículos, os vinte e quatro "plates" que comporiam o livro The Pencil of Nature ${ }^{124}$ - por ele organizado com a intenção de mostrar a aplicação de sua técnica fotográfica.

No "plate XIV", intitulado A Escada [Ilustração 1.22], Talbot tece as seguintes considerações:

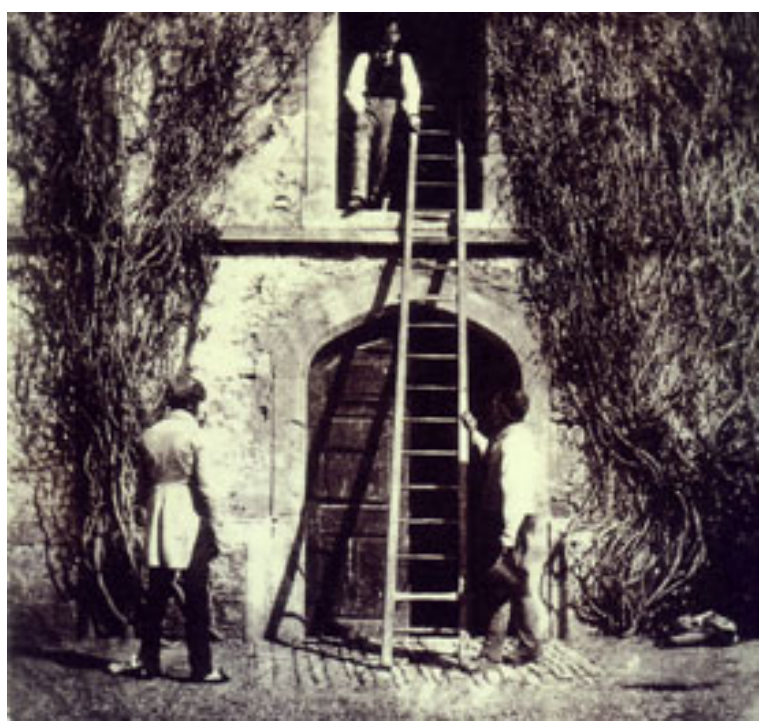

Ilustração 1.22: William Henry Fox Talbot. A Escada, c. 1844-1846 (do livro The Pencil of Nature)

\footnotetext{
123 "O calótipo, ou talbótipo, foi o primeiro processo fotográfico viável baseado no princípio de negativo-positivo, fator fundamental para a reprodutibilidade da imagem fotográfica. O calótipo consistia na utilização de um negativo de papel, sensibilizado com iodeto de potássio e nitrato de prata, geralmente coberto de cera (fator que aumentava a transparência), depois de exposto na câmara escura. A imagem formada no negativo, mas ainda invisível, era então revelada com uma solução de nitrato de prata e ácido gálico. As cópias fotográficas, obtidas por contato, eram realizadas em papel salgado, com o uso de um "sanduíche" de vidro em um chassi de madeira exposto à luz do sol". (Ver TURAZZI, Maria Inez. op. cit., p. 280).

124 "Tradução livre: The Pencil of Nature é um clássico. Trata-se de uma coleção de fotografias em papel feitas pelo inventor do processo, Willian Henry Fox Talbot, com suas considerações sobre a descoberta e suas indicações de como usa-la. Este é o primeiro livro ilustrado com fotografias e a primeira produção de massa de fotografias (...)The Pencil of Nature foi lançado em seis fascículos entre Junho de 1844 e abril de 1846, do seguinte modo: Part 1. Plates I-V; Part 2. Plates VI-XII; Part 3. Plates XIII - XV; Part 4. Plates XVI-XXI; Part 5. Plates XIX-XXI; Part 6. - Plates XXIIXXIV." (The Pencil of Nature is a classic. It is a collection of paper photographs made by the invertor of the process, Willian Henry Fox Talbot, with his account of the discovery and his prediction of the uses to which it might be put. It is the first book illustrated with photographs and the first mass production of photographs (...) The Pencil of Nature appeared in six paper-covered installments between June, 1844, and April, 1846, as follows: Part 1. Plates I-V; Part 2. Plates VI-XII; Part 3. Plates XIII - XV; Part 4. Plates XVI-XXI; Part 5. Plates XIX-XXI; Part 6. - Plates XXII-XXIV."). Ver NEWHALL, Beaumont. Introduction In: TALBOT, Willian Henry Fox. The Pencil of Nature. New York: Da Capo Press, 1969 ). As "plates" são dedicadas a diversos assuntos como vistas (Plate II - "View of the Boulevard"), arquitetura (Plates XII e XIII - "The Bridge of New Orleans" e "Queen's College Oxford - Entrance gateway), além de retratos (Plate XIV - The Ladder), paisagens (Plate XV - Laccok Abbey in Wiltshire), bustos e naturezas mortas, por exemplo.
} 
Retratos de pessoas e grupos formam um dos mais atrativos assuntos da fotografia (...) Quando o sol brilha, pequenos retratos podem ser obtidos pelo meu processo, em um ou dois segundos, mas retratos maiores requerem um tempo mais longo. Quando o tempo está escuro e nublado (...) requer grande paciência do retratado. Imagens de pessoas individuais ou em grupo tomam o mesmo tempo para ser obtidas, uma vez que a Câmera as registra todas de uma vez, por mais numerosas que sejam: porém até o momento não teremos sucesso nesse campo da arte sem um prévio arranjo. Se formos até a Cidade, e tentarmos tirar uma fotografia da multidão em movimento, falharemos, considerando que em uma pequena fração de segundo ela [a multidão] muda tanto de posição, que destrói a dignidade da representação. Contudo, quando um grupo de pessoas tiver sido artisticamente arranjado, e um pouco treinado para manter uma imobilidade absoluta por alguns segundos, imagens maravilhosas serão facilmente obtidas $(\ldots)^{125}$

Talbot comenta, fundamentalmente, nesse trecho sobre a tentativa falha de se registrar dignamente o movimento "da multidão na cidade" pelo processo do calótipo, aludindo à fotografia de rua (o que leva a crer que o fotógrafo realizou experimentos desse tipo), como contraponto às vantagens da fotografia arranjada.

Em A Escada, o fotógrafo "arranja artisticamente" um grupo de pessoas em uma situação que transmite a idéia de ação, embora essa questão não esteja explícita em seu texto: supõe-se que o homem que segura a escada (à direita no canto inferior da fotografia), o faz para auxiliar aquele que está na janela do andar superior da casa, que teria chegado ao local através dela.

125 TALBOT, Willian Henry Fox. The Pencil of Nature. New York: Da Capo Press, 1969 ), plate XIV. 
Portanto, não se trata de um retrato puro e simples, mas sim de uma ação encenada que transmite a sensação de que houve movimento. Sob essa perspectiva, em A Escada Talbot realiza um pseudoflagrante.

O fotógrafo escocês John Thomson foi quem realizou o primeiro livro totalmente voltado à fotografia de rua, que foi publicado em 1877: Street Life in London.

As fotos contidas nesse livro - como Temperance Sweep [Ilustração 1.23] - não parecem revelar interesse em mostrar uma cena de modo que aparente espontaneidade. Pelo contrário. Note-se que em Temperance Sweep, o fotógrafo se utiliza explicitamente do recurso da pose ${ }^{126}$.

Essa característica das fotografias de Thomson desse livro revela tanto uma maneira de o fotógrafo lidar com as limitações técnicas do colódio, como o contexto da fotografia inglesa da segunda metade do século XIX, chamada "vitoriana", a qual não valorizava a espontaneidade:

O fato de a técnica do colódio enfatizar a nitidez em detrimento de outras qualidades como a velocidade tanto da preparação da chapa como da emulsão em si, encorajou fotógrafos como Thomson a realizar fotografias com seres humanos meticulosamente posadas de modo a enfatiza-los na imagem, durante os longos tempos de exposição (...) A espontaneidade não era uma característica da fotografia Vitoriana(...) O ideal que as fotografias de rua de Thomson aspirava era menos a observação cândida da vida do que a observância de determinadas propriedades ${ }^{127}$.

\footnotetext{
${ }^{126} \mathrm{O}$ fotógrafo pictorialista Even O. G. Rejlander, diferentemente de Thomson que fotografava na rua, produzia cenas de rua em seu estúdio. Porém, ao contrário de Thomson, Rejlander tentava transmitir certa espontaneidade à cena. Em uma delas, Rejlander suspendeu uma castanha em uma linha, parecendo que ela tinha sido jogada no ar. Ver WESTERBECK e MEYEROWITZ, op. cit. p. 74.

${ }^{127}$ Idem, ibidem.
} 


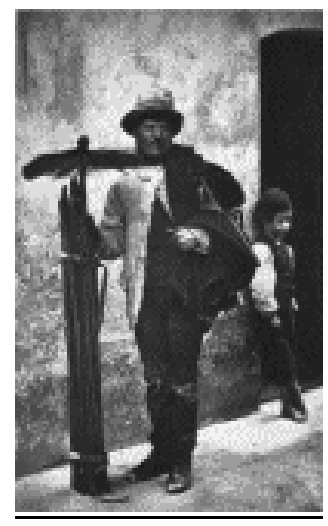

Ilustração 1.23: John Thomson. Temperance Sweep, 1877-1878.

\section{$\underline{\text { A Instantaneidade e a estereoscopia }}$}

O problema encontrado pelos primeiros fotógrafos para captar cenas em movimento, começaria a ser superado a partir de 1851 quando a câmara estereoscópica - desenvolvida, em 1849, pelo cientista escocês David Brewster ${ }^{128}$ - entrou no mercado. A tecnologia da câmara estereoscópica traria ao congelamento do movimento alguma eficiência, fato que se tornou notório com as vistas estereoscópicas urbanas, as quais registravam, geralmente, a movimentação de pedestres nas ruas ${ }^{129}$.

Realizada com uma câmara de duas objetivas, a vista estereoscópica consistia em registrar pares de fotografias que retratavam uma mesma cena, tanto tomada pela perspectiva do olho direito, como do esquerdo. Em seguida, as duas imagens eram observadas simultaneamente em um visor binocular especial, que causava a sensação de tridimensionalidade.

\footnotetext{
${ }^{128}$ O cientista escocês David Brewster, desenhou e simplificou o estereoscópio criado pelo físico inglês Charles Wheatstone, em 1832.

${ }^{129}$ As vistas estereoscópicas geralmente eram montadas em um cartão. O cartão estereoscópico foi um "formato extremamente popular no século XIX, sobretudo para vistas e paisagens. Consistia na montagem de um cartão (medindo $9 \times 18 \mathrm{~cm}$, aproximadamente) com duas fotografias ligeiramente diferenciadas (a cena vista pelo olho direito e a cena vista pelo olho esquerdo). Observadas simultaneamente em um visor especial, as duas imagens do cartão formavam uma imagem única, vista em três dimensões, isto é, possuindo relevo e profundidade. As fotografias estereoscópicas eram realizadas com o emprego de uma câmara de duas objetivas e foram produzidas nos vários processos fotográficos da época" (TURAZZI, Maria Inez. op.cit., 1995, p. 281).
} 
Sucesso na Grande Exposição de Londres, de 1851, - evento que popularizou o uso e consumo da fotografia - a estereoscopia se tornaria extremamente popular no decorrer do século XIX e poderia ser realizada por meio dos diversos processos fotográficos da época tais como o daguerreótipo, o calótipo, o albúmen e o colódio úmido, por exemplo. Devido a essa popularidade, em 1854, se formaria a London Stereoscopic Company, chefiada por Willian England, fotógrafo de vistas estereoscópicas.

O espírito experimental e inovador da estereoscopia se tornaria explícito também no interesse pela troca de informações entre fotógrafos sobre os resultados obtidos, em revistas como a britânica Photographic Notes.

Em 1859, o editor dessa revista, Thomas Sutton, receberia algumas vistas estereoscópicas de autoria de Edward Anthony, realizadas em ruas de Nova lorque, em dias chuvosos [llustração 1.24].

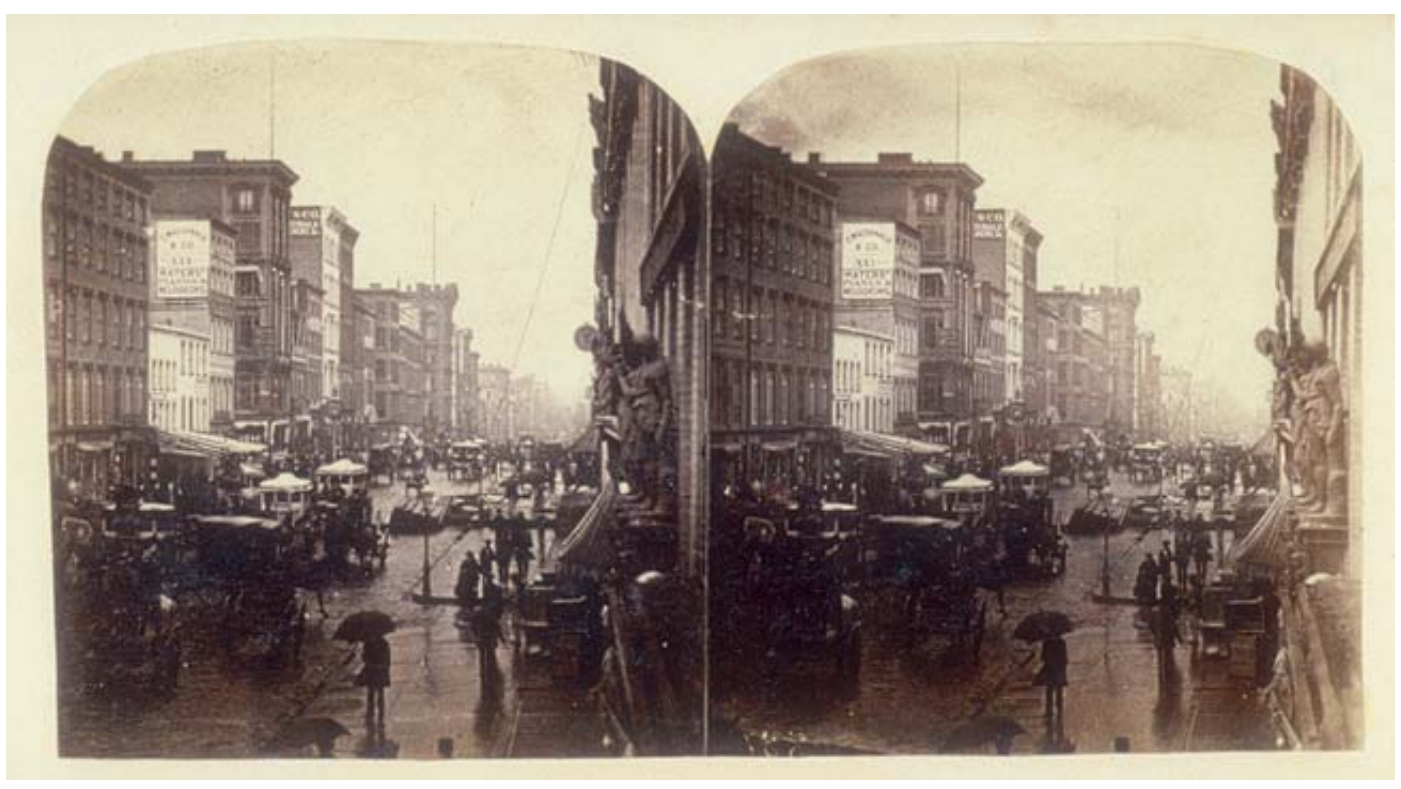

Ilustração 1.24: Edward Anthony. Broadway em um dia chuvoso, 1859. Nova lorque. Cópia em albumina a partir de negativo em vidro ${ }^{130}$

130 Segundo informação constante de uma página do site do The Metropolitan Museum of Art (http://www.metmuseum.org/toah/hd/adag/hod 1980.1056.3.htm), "Edward Anthony e seu irmão Henry foram fundadores da primeira manufatura de suplementos fotográficos. Em 1859, Anthony publicou uma série de suas próprias vistas estereoscópicas "instantâneas", incluindo Broadway on a Rainy Day (Broadway em um Dia Chuvoso). Notável por sua clareza cristalina, esta fotografia vendeu milhares de cópias e ainda está entre as mais colecionáveis imagens da cidade de Nova lorque". Essa "clareza cristalina" deve-se ao emprego do colódio úmido em combinação 
Anthony enviara ao editor, junto com as fotografias, uma carta datada de 29 de Agosto de 1859 perguntando se ele tinha conhecimento de fotografias como àquelas de sua autoria, mas realizadas na Europa. Anthony gostaria de compará-las $^{131}$.

Entre 1860 e 1920, a vista estereoscópica estaria tão difundida que cada lar britânico, europeu e americano iria possuir uma versão de mão (mais acessível), do visor estereoscópico [llustração 1.25].

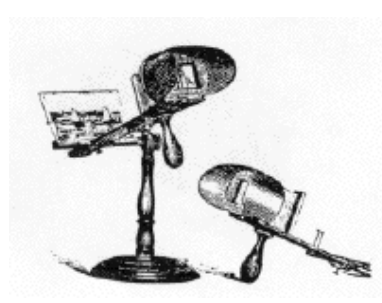

Ilustração 1.25: Visor estereoscópio de mão utilizado nos lares britânicos, europeus e americanos, entre 1860 e 1920.

\footnotetext{
com a cópia em papel albuninado que "preserva a máxima nitidez". Segundo John Szarkowski (tradução livre): "No novo processo de Archer sais sensitivos eram suspensos em uma solução de colódio úmido composta de nitrocelulose e álcool. Esse processo foi chamado de chapa úmida, uma vez que requeria que a chapa de vidro fosse emulsionada, sensibilizada e exposta antes que o colódio começasse a secar. O método produzia negativos mais nítidos que o querido daguerreótipo com a vantagem de possibilitar múltiplas cópias; além disso, no início do dia o processo do colódio úmido era talvez cinco vezes mais sensitivo que negativo em papel encerado de Le Gray. No ano anterior Blanquart-Evrad havia inventado um papel fotográfico que era um perfeito complemento para as novas chapas. Primeiro emulsionando o papel com clara de ovo, ele selava a sua superfície de modo que os sais de prata fossem capturados pela emulsão ao invés de penetrar no corpo do papel, preservando assim máxima nitidez. "(..)In Archer's new process the sensitive salts were suspended into a watery colloid comprised of guncotton (nitrocellulose) and alcohol. It was called the wet-plate system, since it required that the glass plate be coated, sensitized, exposed, and processed before the colloid begun to dry. The method produced negatives hard-edged, eagle-eyed clarity of beloved daguerreotype with the potential for multiple original prints, and by the standards of the day were fast - perhaps five times as sensitive as Le Gray's waxed-paper negativies. The previous year Blanquart-Evrard had invented a photographic paper that was a perfect complement to new plates. By first coating the paper with whipped egg whites he sealed its surface so that the silver salts were captured in the smooth surface emulsion, rather than soaking into the body of the paper, thus preserving maximm sharpness(...)". Ver SZARKOWISKI, John. Paper versus Glass In: SZARKOWISKI, John. Photography until now. New York: Bulfinch Press, Bulfinch Press/Little, Brown and Company New York 1989.

${ }^{131}$ O editor Thomas Sutton responderia na revista que só conhecera "duas ou três", fotografias de George Washington Wilson, que talvez pudessem servir de comparação às de Anthony. O próprio George Wilson responde na revista que as fotografias de Anthony eram muito mais rápidas que as dele de modo que considerava necessário adquirir alguns obturadores para abrir e fechar rapidamente. (Ver BEAUMONT, Newhall. The Conquest of Action In: The History of Photography from 1839 to the present. New York: Museum of Modern Art, 1982, p.117).
} 


\title{
Anos 1880 a 1890: o impulso à captação do instante pela introdução no
}

\author{
mercado das câmaras portáteis e o papel do fotoamadorismo
}

A captação do instante começa a se tornar possível com as câmaras de mão também conhecidas como detective cameras ou spy cameras $^{132}$.

Apesar disso, o impulso ao instantâneo ocorre com as câmaras portáteis que a Kodak lança em 1888, sob o lema "you press the botton, we do the rest" (você aperta o botão e nós fazemos o resto), incentivando a democratização da fotografia (qualquer pessoa pode realizar uma foto).

A utilização das câmaras Kodak propicia a difusão de experimentos fotográficos de ordem amadora, revelando uma nova estética fotográfica ${ }^{133}$.

Nesse contexto, o pseudoflagrante será praticado não mais por impossibilidade técnica, mas por uma questão conceitual ligada, sobretudo, ao amadorismo.

No fotoamadorismo, a fotografia era tida como um ato espontâneo que não requeria conhecimentos técnicos profissionais. Tal espontaneidade se manifestava em situações da vida cotidiana do amador e, talvez por isso, retratasse eventos relacionados a esse universo como rituais religiosos - tais como casamentos e batizados -, e situações de lazer, como festas, férias e

\footnotetext{
${ }^{132}$ Segundo Jorge Pedro Sousa, as câmeras de pequeno formato já eram comercializadas desde a década de oitenta do século XIX. O autor esclarece que só em meados do século XX "é que a qualidade das câmaras menores melhorou ao ponto de se tornar possível a sua utilização profissional". As câmaras detetive, como a Facile, foram empregadas tanto no fotojornalismo, cuja utilização incentivou a prática do foto-ensaio e da obtenção de seqüências, como no amadorismo. Paul Martin foi um exemplo de fotógrafo amador que fotografava com a Facile. (Ver SOUSA, Jorge Pedro. Uma História Crítica do Fotojornalismo Ocidental. Chapecó: Grifos, Florianópolis: Letras Contemporâneas: 2000, p. 73 e WESTERBECK \& MEYEROWITZ, op. cit. p. 103 ).

133 "Desde que a Kodak foi pioneira na manufatura de uma câmara faça você mesmo, nenhuma consideração sobre a fotografia amadora poderia ser completa sem levar em conta a influencia desta companhia (...) Na Inglaterra, Eastman Kodak oferecia uma câmara a amadores e conectava o nome da Kodak aos trabalhos dos mais notáveis (...) O interesse da Kodak em se orgulhar do amadorismo a levou a ser uma importante benfeitora de foto clubes como o The Linked Ring. Davison [George, diretor da gerência da Kodak na Inglaterra], solicitou o suporte de renomados fotógrafos e os enviava novos modelos de câmera para serem testados(...) (Ver WESTERBECK \& MEYEROWITZ, op. cit. p. 102).
} 
passeios, nos quais figuravam amigos e parentes (terreno fértil para a encenação):

(...)Em pouco tempo, a fotografia vai permitir o amadorismo das cabeças cortadas . E também disseminar as idéias compositivas estereotipadas da foto bonita, lisa e aplanada no sentido, bem centrada (...)Mas, por outro lado, também permitirá ao amador tornar-se um criador e até mesmo num caçador de imagens, garantindo que os acontecimentos marcantes das histórias individuais e familiares ganhem uma memória. Batismos, casamentos, férias, ganham uma dignidade fotográfica $(\ldots)^{134}$

\section{Segundo os autores Westerbeck e Meyerowitz:}

É difícil dizer em que ponto do século XIX a fotografia profissional abriu espaço para a amadora começar. Muitos fotógrafos passaram de um lado a outro, de modo que a linha entre as duas categorias se borrou. (Enquanto [Frank] Sutcliffe era um profissional que ganhou reconhecimento dos amadores, seu contemporâneo inglês, Paul Martin era um amador que eventualmente transformou seu hobby em uma profissão). Contudo, existe uma pessoa para quem a diferença entre as duas categorias nunca foi vaga: Alfred Stieglitz ${ }^{135}$.

Para Stieglitz e seu círculo, a palavra "amador" equivalia à "artístico", como colocou certa vez um curador do fotógrafo chamado Weston Naef ${ }^{136}$. Stieglitz acreditava que para ser uma arte a fotografia tinha de ser praticada estritamente por paixão.

\footnotetext{
${ }^{134}$ Ver SOUSA, Jorge Pedro. op. cit., p. 45.

${ }^{135}$ Ver WESTERBECK e MEYEROWITZ, op. cit. p.89.

${ }^{136}$ Idem, ibidem.
} 
Alfred Stieglitz foi um dos primeiros americanos a serem chamados para integrar o The Linked Ring ${ }^{137}$, fundado em 1892. Em 1902, Alfred Stieglitz criou seu próprio grupo, denominado de Photo Secession ${ }^{138}$ composto por fotógrafos que tinham deixado o Camera Club de Nova lorque.

Dentro de um contexto de crescente interesse pela fotografia de rua, Alfred Stieglitz teria papel de destaque. Além de fomentar talentos nessa área em seu jornal, o Camera Work, como o inglês Paul Martin ${ }^{139}$, o próprio Stieglitz realizou fotografias de rua que, inclusive, seriam premiadas.

Uma das mais conhecidas fotografias de Stieglitz nesse contexto é Inverno - Quinta Avenida ${ }^{140}, 1893$ [Ilustração 1.25], a qual foi precursora no contexto de straight photgraphy ${ }^{141}$, difundido pelo fotógrafo, principalmente, no início do século $X X$ : a neblina que aparece na imagem não é fruto de manipulação da cópia fotográfica e sim resultado de uma fotografia direta, sem intervenções, realizada em uma tempestade de neve.

\footnotetext{
${ }^{137}$ Associação amadora fundada por Frank Sutcliffe, na Inglaterra, em 1892, quando vários fotógrafos da Photographic Society of Great Britain a deixam para formar a The Linked Ring. Ver WESTERBECK\&MEYEROWITZ, op. cit. p, 89.

${ }^{138} \mathrm{O}$ nome Photo Secession se deve a prática do pictorialismo entendida de maneira diversa pelos fotógrafos do grupo, formando correntes que disputavam determinadas questões estéticas, como a manipulação ou não da imagem e do negativo. Ver WESTERBECK\&MEYEROWITZ, op. cit. p, 90.

${ }^{139}$ Paul Martin foi um importante nome no amadorismo inglês que costumava usar uma câmara escondida (candid photography) para realizar fotografias em locais públicos, fato que era tido como "fora da lei": "Antes da Primeira Grande Guerra, existiam muitos locais públicos nos quais fotografar era contra a lei. Em Londres, era necessário uma permissão para tirar fotografias nos parques que Pau Martin freqüentava, e um fotógrafo que fosse pego fazendo snapshots da multidão ao invés da paisagem, poderia ser preso (...) Essas proibições refletiram em uma repressão no período Vitoriano, o que acabou por requerer que a fotografia de rua levasse uma vida secreta. Fotógrafos que trabalhavam sob essas restrições em locais públicos iriam recorrer a disfarces como as lentes falsas de Strand [Paul], ou passariam a adotar as novas 'detetive cameras'” (Ver WESTERBECK\&MEYEROWITZ. Op. cit. p. 96).

${ }_{140}$ Sobre essa fotografia o próprio Stieglitz comenta: Tradução livre: "Para obter fotografias com uma câmara de mão é bom escolher o assunto, as figuras e cuidadosamente estudar as linhas e a luz. Depois de ter determinado isso, observe os transeuntes e espere o momento no qual todos os elementos estejam equilibrados; ou seja, que satisfaça o seu olho. Isto geralmente significa horas de paciência esperando. Minha fotografia Inverno - Quinta Avenida, é resultado de três horas em pé durante uma severa tempestade de neve no dia 22 de fevereiro de 1893, esperando pelo momento certo (...)". In order to obtain pictures bu means of the hand câmera it is well to choose your subject, regardless of figures, and carefully study the lines and lighting. After having determined upon these watch the passing figures and await the moment in which everything is in blance; that is, satisfies your eye. My picture "Fifth Avenue, Winter", is the result of a three hours' stand during a fierce snow-storm on February $22^{\text {nd }}, 1893$, awaiting the proper moment(..). Ver STIEGLITZ, Alfred. The Hand Camera - its present importance. In: LYONS, Nathan. Photographers on photography. New Jersey: Prentice-Hall, Inc, Englewood Ciffs; New York, The George Eastman House, 1966.

${ }^{141}$ Para Alfred Stieglitz, a straight photography seria sinônimo de fotografia artística por levar em conta a pureza da imagem - que enfatizava seus elementos formais -, além de mostrar a fotografia como um meio único, com possibilidades únicas. Tradução livre: “(...) Os defensores da fotografia pura ou direta acreditam que pela manipulação da ampliação perde-se a pureza dos tons que pertencem especialmente ao media fotográfico, na tentativa de obter efeitos que podem ser mais satisfatoriamente obtidos pelo pincel do pintor. (...) The advocates of pure or straight photography feel that by manipulating a print you lose the purity of tone which belongs especially to the photographic medium in trying to get effects that can be more satisfactorily obtained by the painter's brush". Essa passagem refere-se a um trecho publicado pelo New York Times em 1912, em decorrência da exposição que Stieglitz organizou em seu estúdio. Ver CLARK, Graham. op. cit. p. 168.
} 


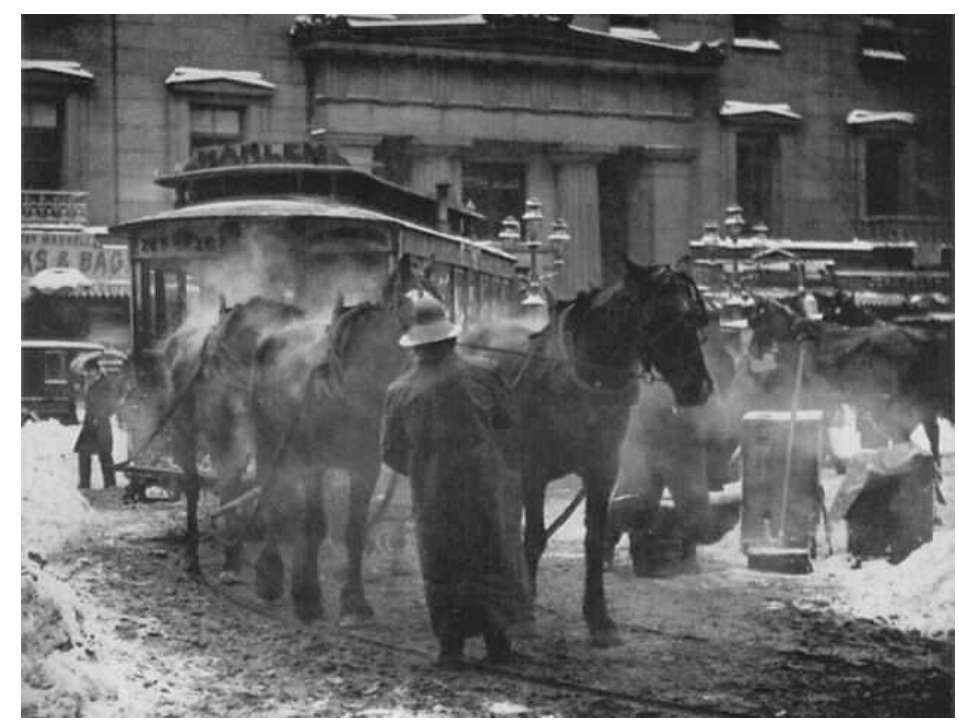

Ilustração 1.25: Alfred Stiegliz. Inverno - Quinta Avenida, 1893.

\section{Os primórdios do fotojornalismo na Europa e Estados Unidos}

A fotografia de rua e o instantâneo são partes inseparáveis, uma vez que a busca do fotógrafo de rua é obter um flagrante de uma ação que se desenvolve no ambiente urbano, mesmo que por razões técnicas ou conceituais isso acarrete o seu falseamento (pseudoflagrante).

A busca do fotógrafo de rua pelo flagrante será uma peça fundamental para o aparecimento do fotojornalismo, que irá enxergar o ato de flagrar como testemunho. 


\section{Segundo o autor Jorge Pedro Sousa:}

As primeiras manifestações do que viria a ser o fotojornalismo notam-se quando os primeiros entusiastas da fotografia apontaram a câmara para um acontecimento, tendo em vista fazer chegar essa imagem a um público, com intenção testemunhal ${ }^{142}$.

O autor ainda completa que:

(...) a fotografia é utilizada como news médium, entrando na história da informação, desde, provavelmente, 1842, embora, com propriedade, não se possa falar de fotojornalismo nessa altura. Aliás, o fotojornalismo necessita de processos de reprodução que só se desenvolvem a partir do final do século XIX - até meados do século passado, desenhistas, gravuristas e gravuras de madeira eram intermediários entre fotógrafos e fotografias e os leitores. De fato, a publicação direta de fotografias só se tornaria possível com as zincogravuras, que surgiram ao virar do século ${ }^{143}$.

Será em meados do século XIX que surgirão as revistas ilustradas pioneiras em utilizar a fotografia como base para as ilustrações, normalmente, em xilogravura. A primeira, The Illustrated London News, é fundada em maio de 1842 em Londres, por Herbert Ingram. Em 1843 nasce, em Paris, a L'Illustration, e, em Leipzig, a Illustrirte Zeitung. Outras revistas oitocentistas de destaque foram: La Illustración, fundada em Madri (1849), Frank Leslie's Illustrated Newspaper, em Nova lorque (1855), Le Monde Illustré, em Paris (1857), Harper's Weekly, em Nova lorque (1857) e Vsemirnaya Illystratziya, São Petesburgo (1869).

${ }^{142}$ SOUSA, Jorge Pedro. op.cit.. p. 25.
${ }^{143}$ Idem.ibidem. 
Um caso que teria iniciado esse percurso foi a publicação, na The Ilustrated London News ${ }^{144}$, na Inglaterra, de desenhos das ruínas de um bairro de Hamburgo destruído por um incêndio, em 1842, realizados a partir do daguerreótipo de autoria de Carl Fiedrich Stelzener ${ }^{145}$.

Nos Estados Unidos, 1844 teria sido o ano da realização da primeira fotografia de um acontecimento público. Trata-se do daguerreótipo de Willian e Fredecrik Langenheim, que mostrava uma multidão reunida na Filadélfia devido à eclosão de uma série de motins anti-imigração.

No entanto o passo decisivo para o desenvolvimento tanto do fotojornalismo como da valorização do instantâneo, foi dado a partir da cobertura da Guerra da Secessão, ou Guerra Civil Americana, que ocorreu entre 1861 e 1865, nos Estados Unidos.

\section{As guerras na Europa e nos Estados Unidos e o desenvolvimento do} $\underline{\text { fotojornalismo no século XIX: bases para a valorização do instantâneo }}$

A primeira guerra considerada precursora no envio de correspondentes para a realização de reportagens fotográficas foi a Americano-Mexicana (18461848), na qual um daguerreotipista anônimo registrou oficiais e soldados.

Depois, a guerra teria servido de tema para a fotografia em outros eventos bélicos como as Guerras Sikh (1848-49), na Índia inglesa, e a Guerra da Birmânia (1852).

\footnotetext{
${ }^{144}$ Embora a The llustrated London News tenha sido uma revista semanal que se manteve durante bastante tempo à frente das publicações ilustradas da época, este fato não significou que a revista tivesse à frente também dos padrões praticados pela mídia impressa de então. Pelo contrário, a questão de reproduzir diretamente uma fotografia constituiuse um problema para os primeiros jornais e revistas. Fora isso, deve-se levar em conta que o gosto da época privilegiava o desenho. Ver SOUSA, Jorge Pedro. op. cit. p. 26.

${ }^{145} \mathrm{O}$ desenho baseado no daguerreótipo de Stelzener, sobre o incêndio de um bairro em Hamburgo, pode não ter sido a primeira ilustração de um acontecimento publicado em um semanário ilustrado. No mesmo ano em que foi veiculada essa imagem, a própria The Illustrated London News teria publicado uma gravura que buscava encenar uma tentativa de assassinato da rainha Vitória.
} 
Porém, foi o conceito de reportagem fotográfica desenvolvido na Guerra da Criméia (1854-56) que serviu de base para o registro de grandes acontecimentos posteriores, como será o caso da Guerra da Secessão (1861$65)^{146}$ que será vista na seqüência.

O interesse popular pela participação britânica na Guerra da Criméia levaria o editor Thomas Agnew, da Thomas Agnew \& Sons Ltda., a convidar um fotógrafo para cobri-lo: Roger Fenton ${ }^{147}$, então fotógrafo oficial do Museu Britânico.

Cabe lembrar que a imprensa ilustrada da época utilizava-se da gravura como mediadora da fotografia para ilustrar um fato. Assim, seguia o padrão de ilustração que foi visto em exemplos anteriores de acontecimentos veiculados na mídia impressa, como a destruição de um bairro de Hamburgo pelo fogo, em 1842, no The llustrated London News.

Desse modo, as fotografias que Fenton obteve do embate foram publicadas sob a forma de gravura no mesmo The Ilustrated London News e também no Il fotógrafo, de Milão, ambas em $1855^{148}$.

As fotografias de Fenton constituíriam, segundo Sousa, "o primeiro indício do privilégio de que o fotojornalismo vai conceder à cobertura de conflitos bélicos ${ }^{149 "}$.

\footnotetext{
${ }^{146}$ Acontecimentos como o conflito entre a Áustria e a Sardenha (1859), a colonização da Argélia (1856/57), as rebeliões na Índia (1857/58), a intervenção britânica na China, durante as Guerras do Ópio (1860), o ataque da Prússia e da Áustria à Dinamarca (1864) e a Guerra Franco-Prussiana, onde Disderí chegou a fotografar as ruínas de St. Claud (1870). (Ver SOUSA, Jorge Pedro. op. cit. p. 35).

${ }^{147}$ Segundo o autor Jorge Pedro SOUSA "É preciso que se note que as fases iniciais do conflito da Criméia, que se desenrolaram nos Balcãs, podem ter sido registradas por Karl Baptist de Szathmari, um amador de Bucareste, mas as fotos não sobreviveram, pelo que se desconhece o seu conteúdo. Durante a Guerra da Criméia salientou-se ainda um outro fotógrafo, também britânico: James Robertson (...) Um outro 'proto-fotojornalista' desses tempos foi um associado de Robertson, Felice Beato (c. 1830-1906) (...)". Ver SOUSA, Jorge Pedro, op.cit., p. 34 e 35.

${ }^{148}$ Idem. ibidem, p. 33.

${ }^{149}$ Idem, ibidem.
} 
Roger Fenton teria permanecido na guerra de 8 de março a 26 de junho de 1855 , fotografando o embate e produziu por volta de 360 fotografias nesses quase quatro meses.

Essas fotografias documentavam os oficiais - geralmente em seus acampamentos ou a cavalo -, e a paisagem bélica, deixando de lado cenas de combate ou dos efeitos devastadores da guerra. Esse fato passou uma visão idealizada e heróica do conflito, no estilo de uma epopéia [llustração 1.26].
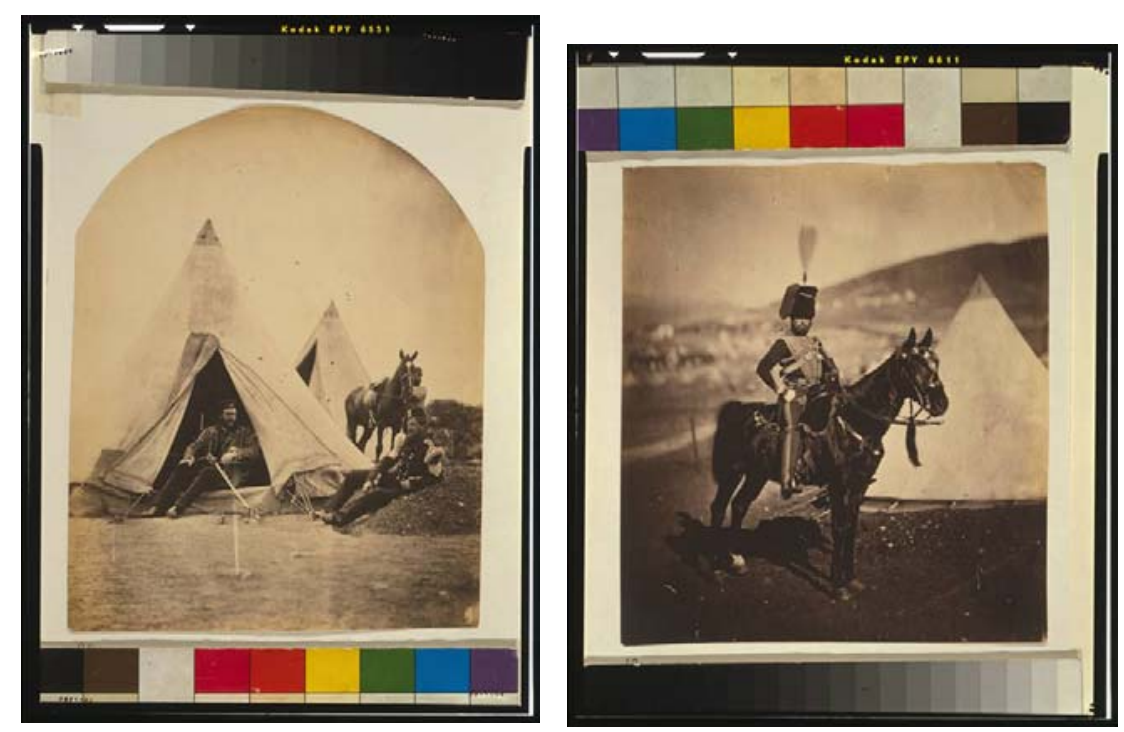

Ilustração 1.26 : Exemplos de fotografias realizadas por Roger Fenton durante a Guerra da Criméia.

Essa abordagem deveu-se em parte a uma espécie de censura considerando que foi uma reportagem encomenda por Agnew —, e em parte às dificuldades técnicas decorrentes do emprego do colódio úmido, tais como: o ritual antes, durante e após a realização da fotografia -, como a présensibilização da chapa, a exposição na câmara escura e sua revelação imediata dada à secagem rápida do colódio. Isso, além da falta de mobilidade do fotógrafo para captar imediatamente uma ação, devido ao pesado 
equipamento que utilizava (câmera com tripés e uma carroça-laboratório para transportar o equipamento).

Esses retratos da Guerra da Criméia demonstraram uma nova possibilidade com relação ao gênero "retrato" atrelado à pose e ao estúdio fotográfico.

O fotógrafo tem de adaptar a proposta de retrato ao fato de estar em um campo de batalhas, em condições de improviso: seu laboratório fotográfico é móvel, não existe a possibilidade de um estar em um estúdio para realizar as poses com aqueles que serão fotografados.

Assim, os retratados não se apresentam em poses tão rígidas, há certo relaxamento em suas posturas diante da câmara. Apesar disso, ainda não se trata da espontaneidade obtida em um flagrante, mas de um passo nessa direção.

Essa experiência fotográfica obtida pela imprensa ilustrada durante a Guerra da Criméia, irá influir diretamente naquela da Guerra da Secessão, que foi o primeiro evento bélico a ser massivamente coberto por fotógrafos ${ }^{150}$. Como conseqüência, este fato, entre outros que ainda serão vistos, iria gerar o desenvolvimento do fotojornalismo.

Se por um lado, diferentemente do que ocorreu na Guerra da Criméia, na Guerra da Secessão mais de um fotógrafo a documentou oficialmente como é o caso de Mathew Brady ${ }^{151}$ e seus colaboradores, Alexander Gardner, Timothy O'Sullivan e George N. Barnard -; por outro, a forma de retratá-la, pelo menos no início do conflito, seria similar: mostravam-se "(..) imagens

\footnotetext{
${ }_{151}^{150}$ Ver SOUSA, Jorge Pedro. op. cit. p. 35.

151 Segundo Jorge Pedro SOUSA "A associação de Brady.(que raramente operava a câmara), com os seus colaboradores ruiu, quando estes começaram a reclamar do fato de Brady assinar todas as fotos(...)Devido ao malestar desencadeado pela atuação de Brady, Gardner, por exemplo, dissociar-se-á do seu contratante a meio da guerra(...)" p.36
} 
idealizadas de oficiais garbosos a conduzir ordeira e heroicamente os seus soldados na frente", como descreve o autor Jorge Pedro Sousa.

Alguns anos após o seu início, entretanto, as imagens da Guerra da Secessão se aproximariam da foto-choque, associada à estética do horror, embora pudessem apresentar ainda certa idealização do fato.

Um exemplo desse tipo de idealização é a fotografia Casa de um soldado rebelde (1863) [llustração 1.27] do escocês Alexander Gardner, na qual o fotógrafo rearranja o corpo de um soldado sulista morto na guerra. Esse mesmo corpo teria sido utilizado como se fosse o de um soldado da União ${ }^{152}$, em outra fotografia de sua autoria: A última morada de um soldado.

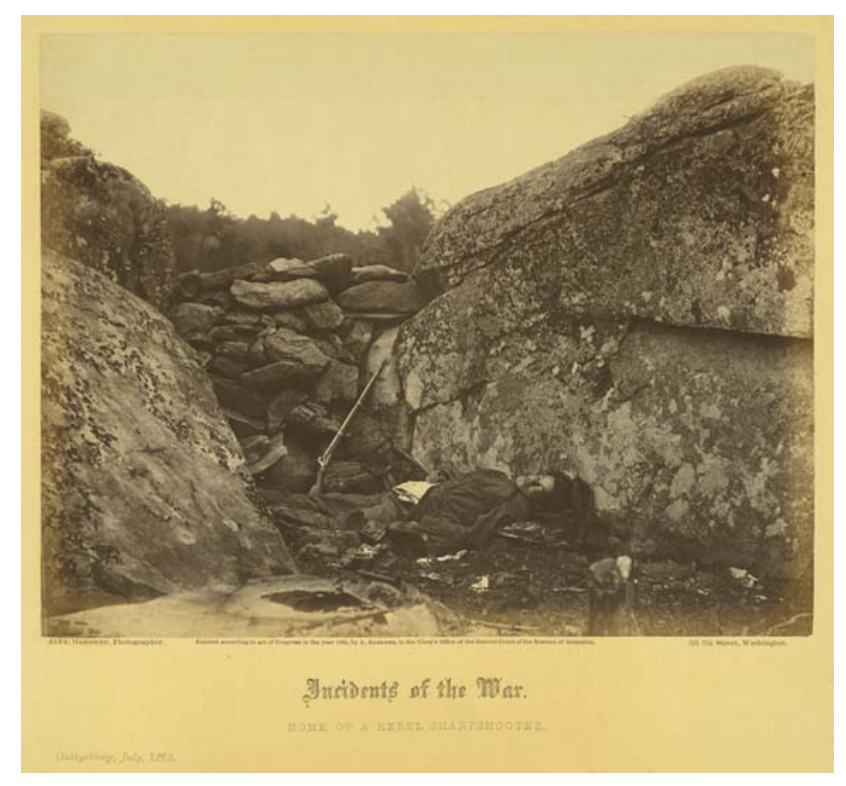

Ilustração 1.27: Alexander Gardner, Casa de um soldado rebelde, 1863.

Aqui teremos um dos "primeiros exemplos de encenação ficcional e manipulação do evento no campo do fotojornalismo ${ }^{153 ",}$, ou seja, em nome da noção de "soldado herói", além das existentes dificuldades técnicas para captar

\footnotetext{
152 Idem, ibidem.

153 Idem, ibidem.
} 
"o momento da morte do soldado", Gardner interfere totalmente no fato realizando um pseudoflagrante.

Note-se que a idealização é mostrada pela simbologia criada na imagem: o cadáver do soldado repousa próximo ao rifle, que está em pé, simbolizando o ato heróico (o soldado foi abatido, mas sua arma está "a postos"). Ao observar a farda aberta mostrando a camisa do oficial, parece que ele morreu de "peito aberto", como se tivesse oferecido sua morte em prol de um sacrifício para um bem maior (combater na guerra). Por fim, apesar de sua perna estar mutilada, ela aparece coberta pela calça mostrando uma "morte digna".

Com relação à publicação das imagens do combate na imprensa ilustrada da Guerra da Secessão, assim como aconteceu na da Criméia, havia de se superar entraves técnicos para a reprodução direta das fotografias.

As imagens relacionadas ao combate publicadas em importantes semanários ilustrados da época, como a Harper's Weekly, New York ilustrated News ou a Frank Leslie's Illustrated Newspaper ${ }^{154}$, eram feitas a partir de fotografias de modo que estas ainda serviam como matriz para a ilustração de um fato de maneira "fiel".

Por exemplo, as xilogravuras que mostravam os corpos esqueléticos de prisioneiros recém libertos do campo de concentração para soldados nortistas de Andersonville - "onde se dizia que morria um prisioneiro a cada onze minutos ${ }^{155 "}$-, publicadas em junho de 1864 na Frank Leslie's Illustrated Newspaper e na Harper's Weekly, foram realizadas com base em fotografias fornecidas por Brady e outros correspondentes.

\footnotetext{
${ }^{154}$ SOUSA, Jorge Pedro, op. cit., p. 35

${ }^{155}$ Essas imagens foram inicialmente realizadas para fins científico-médicos. Idem, ibidem, p. 37 e 38.
} 
Porém, esse exemplo não é apenas importante para pensar na fotografia como uma base para a ilustração.

As gravuras dos prisioneiros de Andersonville publicadas nos referidos semanários ilustrados:

(...)escandalizaram o Norte: não traziam a emoção visceral, intensa e instantânea das foto-choque, mas saber que eram desenhos executados a partir de fotografias potencializava a sua credibilidade e dramaticidade ${ }^{156}$.

E isso seria um passo para que os editores das publicações ilustradas percebessem o impacto das imagens nos leitores, isto é "a fotografia passa a ser vista como uma força atuante e capaz de persuadir devido ao seu 'realismo', à 'verosimilhitude'157."

Além disso, durante a Secessão, os editores também notaram que "a velocidade entre o momento de obtenção da foto e o da sua reprodução era fundamental numa esfera de concorrência $(\ldots)^{158 ",}$, tornando rotina o recurso do comboio para transportar as fotografias até as redações dos jornais.

A partir daí começa a acentuar-se a idéia de cronometralidade, isto é, a importância do imediatismo da notícia. Nesse contexto, segundo os dados levantados por Sousa “(...) por vezes, as fotografias de batalhas eram publicadas menos de uma semana após a sua realização ${ }^{159 "}$.

Foi então que surgiu a idéia "de que era preciso estar perto do acontecimento quando este tivesse lugar", noção que marca o início da valorização do instante em uma reportagem fotográfica e influencia a atuação

\footnotetext{
${ }^{156}$ Ver SOUSA, Jorge Pedro. op. cit. p. 37

157 Idem.ibidem.

158 Idem. ibidem.

159 Idem.ibidem
} 
de fotojornalistas do século seguinte como Robert Capa ${ }^{160}$. Muito embora ainda não fosse totalmente possível captar um instantâneo, devido aos mesmos empecilhos técnicos enfrentados por Roger Fenton na Guerra da Criméia, decorrentes, principalmente, da utilização da técnica do colódio úmido ${ }^{161}$.

Cabe destacar que a somatória de todas essas situações gera tanto o desenvolvimento do fotojornalismo, que iria evoluir ao ponto de instituir formalmente a profissão de fotojornalista nas últimas décadas do século XIX, como da valorização do instantâneo ${ }^{162}$.

\section{A Guerra do Paraguai}

Enquanto o fim da Guerra da Secessão nos Estados Unidos se aproximava, começava na América do Sul a Guerra do Paraguai, conhecida também como Guerra da Tríplice Aliança (1864-1870).

Além do Paraguai, estiveram envolvidos na guerra os países Argentina, Brasil e Uruguai, que se uniram contra o expansionismo paraguaio de Francisco Solano López.

Segundo o pesquisador André Toral, "A Guerra do Paraguai foi a primeira, na imprensa sul-americana, a receber uma cobertura visual ${ }^{163 " .}$

Assim como a Guerra da Secessão dos Estados Unidos, o conflito da Guerra do Paraguai teve ampla cobertura fotográfica, fato que gerou diversas imagens do teatro de operações.

\footnotetext{
${ }^{160}$ No século XX, no qual atua Robert Capa, se instalará a idéia de que "as fotos de batalhas obtém-se ainda com o fumo e o odor a sangue a pairar pelo campo". Ver SOUSA, Jorge Pedro. op. cit. p. 38.

${ }_{161}$ Podem ter sido utilizadas outras técnicas, mas a do colódio úmido predominou.

162 Também teve importância para o desenvolvimento do fotojornalismo a publicação dos primeiros livros fotográficos bélicos, em 1866: o Photographic Sketch Book of the War, de Alexander Gardner, e o Photographic Views of Sherman's Campaing, de George N. Barnard. Segundo SOUSA esses livros configuram "(...) o primeiro exemplo de edições fotográficas organizadas pelos fotógrafos para serem tomadas em conta na hora de se fazer história". Ver SOUSA, Jorge Pedro. op. cit. p.39.

${ }_{163}$ TORAL, André Amaral de. Imagens em Desordem - A iconografia da Guerra do Paraguai (1864-1870). São Paulo: Humanitás/FFLCH/USP, 2001.
} 
Ainda de acordo com Toral, entre 1864 e 1870, em:

(...)algumas capitais de província do Império do Brasil, sobretudo São Paulo e Recife, bem como em Montevidéu e Buenos Aires, diversas publicações especializaram-se em trazer imagens ao público. Eram os jornais ilustrados, pioneiros na imprensa brasileria e nos países platinos ${ }^{164}$.

De modo geral, as imagens do conflito veiculadas na imprensa do período $^{165}$ eram gravuras em pedra (litografia) - no Brasil e Argentina -, ou em madeira (xilogravura) - no Paraguai - e desenhos, que normalmente não mostravam cenas de choque.

Tais imagens podiam tanto basear-se em relatos como serem realizadas a partir de fotografias. Especialmente o uso da litografia na imprensa ilustrada, como era feito na Europa e Estados Unidos, tornará possível a realização rápida de desenhos ou a cópia de fotografias, daguerreótipos e pinturas. Já com relação à xilogravura, somente o Paraguai utilizaria esta técnica para a impressão de seus jornais ilustrados ${ }^{166}$.

A demanda do público por imagens da Guerra do Paraguai propiciou o surgimento de publicações ilustradas especializadas no conflito, especialmente no Paraguai e no Brasil. O interesse era tamanho, que a guerra tornou-se o assunto principal dessas publicações por quase cinco anos ${ }^{167}$.

Segundo os dados de Toral, as principais publicações paraguaias sobre a guerra, entre 1864 e 1870, foram El Centinela, El Cabichuí, Cacique Lambaré

\footnotetext{
164 Idem. ibidem.

${ }^{165}$ Os jornais ilustrados que cobriram a Guerra do Paraguai eram semanais ou quinzenais, e apresentavam de quatro a oito páginas, em formato próximo ao tablóide. Ver TORAL, André, op. cit. p.58.

166 Com relação à litografia, segundo André Toral, "As imagens assim reproduzidas, atingiam um público que não tinha acesso a museus, ateliês ou a estúdios fotográficos e seus produtos(...)". Ver TORAL, André, op. cit. p. 57 . Sobre a imprensa paraguaia ver as págs. 67- 74, da obra deste autor.

${ }^{167}$ Ver TORAL, André. Op. cit. p. 58.
} 
e El Semanário. No mesmo período, na Argentina, os jornais ilustrados Correo del Domingo e El Mosquito se especializaram no conflito. No Brasil, exclusivamente para a cobertura de imagens da Guerra do Paraguai foram criados o Paraguai llustrado e Semanário Panficronológico, Asneirótico, Burlesco e Galhofeiro, este último com duração de dois meses (julho a outubro de 1865). Porém, outros jornais como O Cabrião, em São Paulo, além de a Semana Ilustrada, A Vida Fluminense, Diabo Coxo e Paraguai Ilustrado, no Rio de Janeiro, também cobriram a guerra. Entre esses a Semana Ilustrada, A Vida Fluminense e O Cabrião, tornaram-se célebres pela cobertura imagística do conflito $^{168}$.

Dos países participantes na Guerra do Paraguai, o Brasil, sob regime imperial, teve uma atuação preponderante:

(...)nos anos de guerra o governo brasileiro dedicou-se de tal maneira a ela, que pouco tempo sobrou para as reformas internas. Foram enormes os gastos com a luta: 614 mil contos de réis, onze vezes o orçamento governamental para o ano de 1864, criando um déficit que persistiu até $1889^{169}$.

A repercussão da guerra na imprensa brasileira teve impulso com a atuação do pintor, desenhista, gravador, ilustrador e litógrafo alemão Henrich Fleiuss ${ }^{170}$ que realizou a primeira experiência na imprensa carioca de cobertura

\footnotetext{
${ }^{168}$ Idem, ibidem, p.

169 Ver SCHWARCZ, Lilia Moritz. Uma Batalha de imagens - A guerra do Paraguai em foco In: SALLES, Ricardo. Guerra do Paraguai, memórias e imagens. Rio de Janeiro: Edições Biblioteca Nacional, 2003. A autora cita um trecho do livro O conflito com o Paraguai, de Francisco Doratioto, publicado em 1996 pela editora Ática.

${ }_{170}$ Natural de Colônia (Alemanha) Heinrich Fleiuss nasceu em 29 de agosto de 1823. Segundo o autor Joaquim Marçal Ferreira de Andrade, Fleiuss "Após os estudos iniciais em sua cidade natal, mudou-se para Dusseldorf em busca de aprofundamento nos campos das artes, literatura e ciências naturais. Em Munique, completou seus estudos, neles incluindo, ainda, o aprendizado de música. Chegou ao Brasil em 1858, com o objetivo de integrar-se à missão científica dirigida pelos naturalistas alemães Spix e Martius (que o convidou), missão esta que visava o levantamento da flora local e que foi mais tarde sintetizada na monumental obra Flora Brasiliensis". (Ver ANDRADE, Joaquim Marçal Ferreira de. História da Fotorreportagem no Brasil - A fotografia na Imprensa do Rio de Janeiro de 1839 a 1900 (Rio de Janeiro: Elsevier, 2004)
} 
jornalística com editoriais e notícias ilustradas com publicação sistemática ${ }^{171}$. A investida de Fleiuss ocorreu por meio da revista Semana Ilustrada ${ }^{172}$, da qual foi fundador e editor.

\section{Será em março de 1865 que a fotografia de guerra surgirá} declaradamente nas páginas dessa revista:

(...) essas ocorrências pioneiras da fotografia de guerra em nossa imprensa surgem na forma de dois suplementos ilustrados, associados ao número 221, de 5 de março de 1865. Uma intitula-se "Vistas do Paissandu depois da tomada da praça". Fotografadas do natural e obsequiosamente oferecidas à Semana Ilustrada pelo IIm.e Exm. Srn. Vianna de Lima. O outro, "Acampamento de Infanteria brasileira diante de Paissandu". No fundo as canhoneiras e a ilha para a qual se retiraram muitos habitantes de Paissandú (Tirado do Natural em fotografia) ${ }^{173}$.

\section{Segundo o autor Joaquim Marçal Ferreira de Andrade:}

Foram muitos os fotógrafos que documentaram o evento, em seus diferentes aspectos. E até hoje, nem todas as imagens existentes têm a sua autoria esclarecida. Ali, também temos imagens que retratam os horrores da guerra, tais como cadáveres emplilhados, soldados mutilados e prisioneiros subnutridos. No Brasil, entretanto, tais imagens jamais circularam ${ }^{174}$.

\footnotetext{
${ }_{171}^{171}$ ANDRADE, Joaquim Marçal Ferreira op. cit., p. 132.

${ }^{172}$ Esta revista foi fundada, em 16 de dezembro de 1860, pelos irmãos Carl e Heinrich Fleiuss, além do litógrafo Carl Linde (Fleiuss Irmãos \& Linde) e funcionava na Rua do Ouvidor $n^{\circ} 87$. A Semana Ilustrada foi publicada até 1876, ano em que Heinrich Fleiuss, fundou a revista llustração Brasileira.

${ }^{173}$ Ver ANDRADE, Joaquim Marçal Ferreira de. Op. cit. p. 136.

${ }^{174}$ Contudo essas imagens foram amplamente veiculadas nos diários rioplatenses. Idem, ibidem, p. 132.
} 
A documentação fotográfica formal da Guerra do Paraguai foi realizada pela casa fotográfica Bate\&Cia, do irlandês George Thomas Bate e de seu irmão, então estabelecida na cidade de Montevidéu ${ }^{175}$.

Uma das fotografias que interessa a este estudo nesse contexto é a realizada por Esteban García, intitulada $A$ Morte do Coronel Leon Palleja [llustração 1.28]

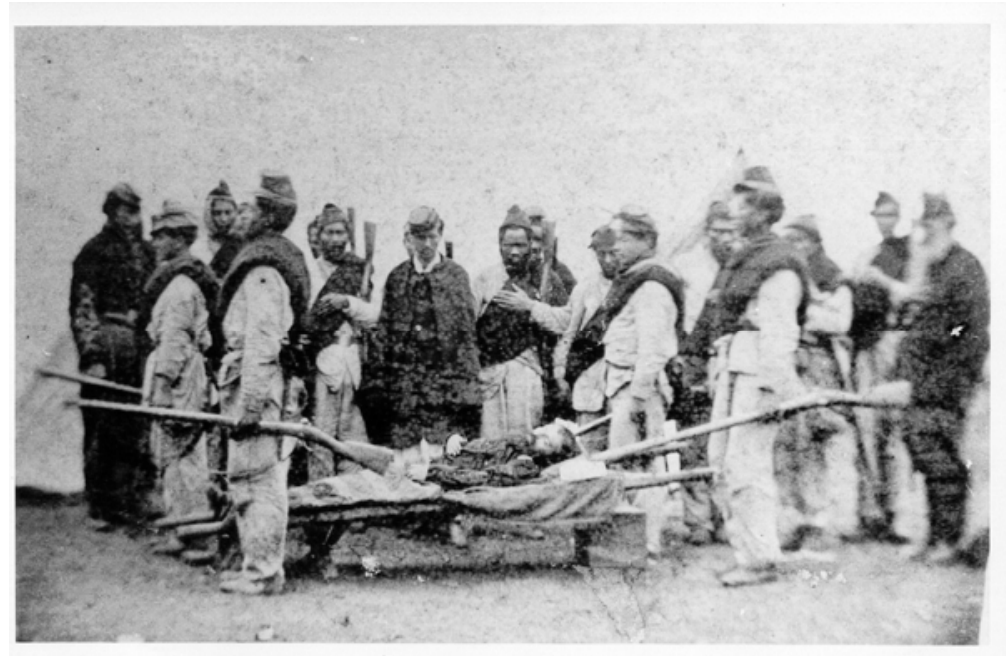

Ilustração 1.27: Esteban Garcia. A morte do Coronel Leon Palleja, 1866. Arquivo Nacional do Uruguai.

Essa fotografia nos transmite a idéia de "flagrante". Certamente Esteban Garcia estava presente no momento em que o cortejo seguia com o corpo do coronel:

Garcia conseguiu, ainda, o primeiro "instantâneo" da guerra, ao retratar o coronel uruguaio Leon Palleja no exato instante em que, ferido mortalmente na batalha do Boqueirão, era levado numa maca para a retaguarda. Soldados negros do batalhão

\footnotetext{
${ }^{175}$ Thomas Bate, e seu irmão, chegaram a Buenos Aires, procedentes dos Estados Unidos, em 1859. Segundo nota explicativa de Joaquim Marçal Ferreira de Andrade, op. cit. "(...)Em 1861 o estabelecimento [Bate y Cia] fixou-se em definitivo na cidade de Montevidéu, no Uruguai. Inicialmente Bate fotografou, com sua equipe, os conflitos havidos no Paissandu, na virada de 1864 para 1865 e que precederam a declaração formal de guerra contra o Paraguai. Iniciada a guerra, Bate dirigiu ao governo uruguaio uma solicitação formal de autorização para documenta-la, incluindo o transporte por aquele exército, além de resguardar para si os direitos exclusivos de reprodução de todas as suas fotografias até seis meses após os términos dos conflitos(...)". p. 271.
} 
uruguaio Florida apresentaram armas ao respeitado oficial, um dos melhores cronistas da primeira fase da guerra ${ }^{176}$.

\section{$\underline{\text { Considerações sobre a fotografia de rua no Brasil: Vincenzo Pastore }}$}

Dentro do contexto que abrange a fotografia no Brasil, de sua chegada no país, em 1840, até meados do século $X X^{177}$, acredito que o fotógrafo que registra o cotidiano de São Paulo - em alguma medida antecipando German Lorca -, seria Vincenzo Pastore, fotógrafo italiano que aqui se estabelece na passagem do século XIX para o seguinte.

Antes de Pastore, no entanto, me parece imprescindível lembrar da figura de Militão Augusto Azevedo ${ }^{178}$, ex-ator e talvez o principal fotógrafo brasileiro a retratar São Paulo no século XIX. Suas tomadas da cidade são nas palavras do historiador Gilberto Ferrez -, “(..)sem par para os estudiosos da velha urbe"179.

Quando ele reúne suas tomadas de São Paulo, realizadas em dois tempos - em 1862 e em 1887 - e contidas no Álbum Comparativo da Cidade

\footnotetext{
${ }^{176}$ Ver TORAL, André Amaral. Op. cit. p. 91. O capítulo em que Toral comenta a fotografia "Morte do Coronel Leon Paella" intitulado "A Fotografia vai a luta" é totalmente dedicado a apontar o papel que a fotografia desempenhou na guerra: "O registro fotográfico da guerra foi, em termos gerais, uma continuação do tipo de fotografia que se fazia entre 1860 e 1870. Mas foi também mais que isso. A força do assunto trouxe uma mudança qualitativa mesmo em gêneros há muito tempo explorados, como retratos e paisagens. Se, por um lado, a guerra ajudou a aumentar as vendas de retratos, por outro lado, sua precoce impopularidade acarretou o insucesso comercial de outros gêneros de fotografias do conflito". (p. 77)

177 "Quando realizada fora dos estúdios, a fotografia brasileira do século XIX é marcadamente documental. Diferente do que ocorreu em alguns países europeus e nos Estados Unidos, as interseções da fotografia com movimentos artísticos e com a pesquisa científica, entre outros gêneros, foram pouco exploradas e desenvolvidas por aqui". Ver ANDRADE, Joaquim Marçal Ferreira de. Op. cit. p. 12. Sobre a fotografia no Brasil no século XIX ver: FABRIS, Annateresa (org.) Fotografia - usos e funções no século XIX. São Paulo: Edusp, 1991; FERREZ, Gilberto. A Fotografia no Brasil 18401900. Rio de Janeiro: Fundação Nacional de Arte/Fundação Nacional Pró-Memória, 1985; KOSSOY, Boris. Origens e expansão da fotografia no Brasil. Rio de Janeiro: Funarte, 1980

${ }_{178}$ Militão Augusto Azevedo nasceu no Rio de Janeiro em 1840. Apesar de ter vivido no Rio de Janeiro viveu a maior parte de sua vida em São Paulo. Militão Augusto de Azevedo produziu mais de 12 mil retratos pelo estúdio Photographia Americana. Em 1862 e 1887 realizou as fotografias de São Paulo que iriam constar do Álbum Comparativo da Cidade de São Paulo. Sobre Militão Augusto Azevedo e a sua atividade na Photographia Americana ver GRANGEIRO, Cândido Domingues. As artes de um negócio: a febre fotográfica: São Paulo 1862-1886. Campinas: Mercado de Letras; São Paulo: FAPESP, 2000.

${ }^{179}$ Ver FERREZ, Gilberto. A Fotografia no Brasil 1840-1900. Rio de Janeiro: Fundação Nacional de Arte/Fundação Nacional Pró-Memória, 1985, p. 181.
} 
de São Paulo ${ }^{180}$ - nota-se que seu interesse reside em demonstrar como a antiga e acanhada cidade, num período inferior a três décadas, passara por uma transformação significativa tanto em seus aspectos urbanos quanto arquitetônicos.

Segundo Tadeu Chiarelli:

O Álbum - além de um documento fundamental para os estudiosos da história da arquitetura e do urbanismo da cidade - transcende o factual e/ou documental para ganhar um sentido mais amplo, permitindo ao observador atingir uma compreensão não apenas (ou propriamente) do crescimento acelerado de São Paulo durante aquele período, mas, sobretudo, permite-lhe perceber de maneira definitiva o caráter inexorável e transitório da vida, do tempo ${ }^{181}$.

Dentro desse caráter "inexorável e transitório da vida", Militão não deixa de captar também o cotidiano da cidade, o seu lado humano, flagrando a movimentação de pessoas pelas ruas ou em frente aos locais que fotografa [llustração 1.28].

\footnotetext{
${ }^{180}$ Ver AZEVEDO, Militão Augusto de. Album comparativo da cidade de São Paulo/1862-1887. São Paulo: Prefeitura do Município de São Paulo: Secretaria Municipal de Cultura, 1981.

${ }^{181}$ Ver CHIARELLI, Domingos Tadeu. Anotações sobre arte e história no Museu Paulista In: FABRIS, Annateresa (org.) Arte e política - algumas possibilidades de leitura. São Paulo: FAPESP; Belo Horizonte: C/Arte, 1998, p. 40.
} 


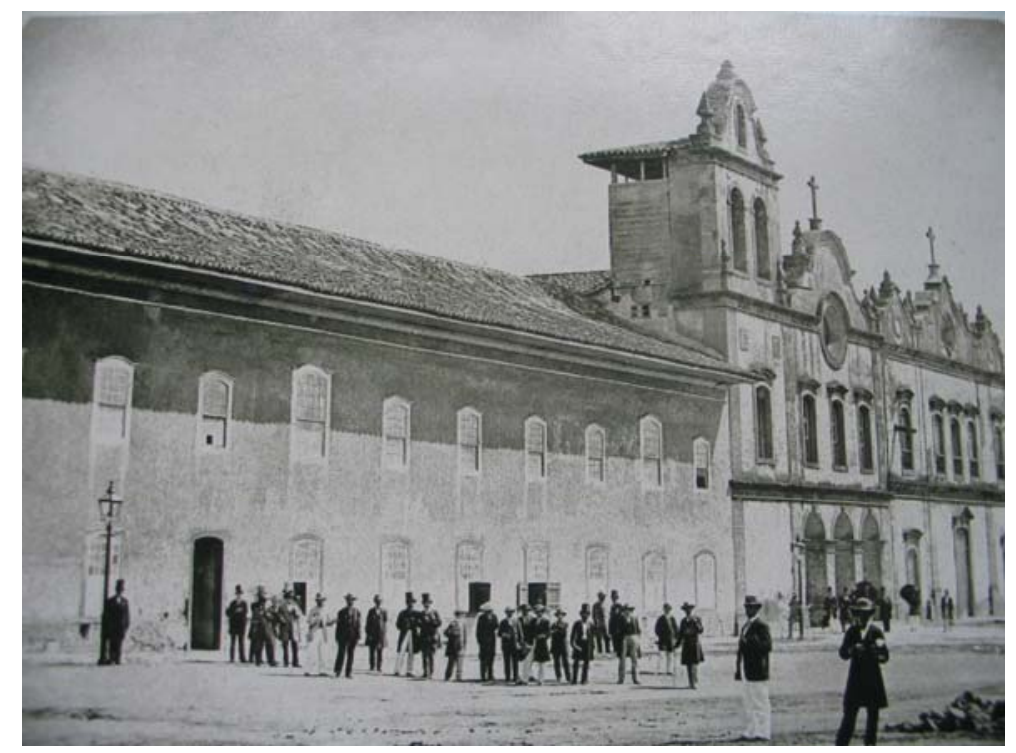

Ilustração 1.28: Militão Augusto de Azevedo. Estudantes em frente à Academia de Direito, instalada no convento de São Francisco em 1838. c. 1862. Acervo Instituto Moreira Salles.

No entanto, um interesse mais direcionado ao cotidiano dos habitantes de São Paulo, será encontrado nas fotografias de rua do já citado Vincenzo Pastore.

Pastore chega ao Brasil, vindo de Casamassima (Itália), no final do século XIX e estabelece seu estúdio Photographia Pastore em São Paulo. A principal atividade de seu estabelecimento era o retrato, individual ou em grupo. No início do funcionamento de seu estúdio, o fotógrafo lança o "Retrato Mimoso"182.

Além desse tipo de retrato, Pastore busca originalidade ao explorar o espaço cênico de seu estúdio para realizar retratos tanto de pessoas bem colocadas na sociedade paulistana de então, como de outros mais marginalizados, como descendentes de escravos e índios. Outro viés da

\footnotetext{
${ }^{182}$ Este nome foi inspirado no corte dos cartões "carte de visite", no formato de um losângulo. O retrato do cliente era inserido dentro de uma moldura losangular. Ver Atílio José Avancini, op.cit.
} 
produção de Pastore é a realização de retratos como brinde para o jornal $O$ Estado de São Paulo e para a revista A Vida Moderna ${ }^{183}$.

Ainda por meio de seu estúdio, Vincenzo Pastore passa a produzir com freqüência capas para as revistas A Vida Moderna e A Cigarra, entre 1914 e 1917, na maioria, retratos de mulheres jovens.

No entanto, foi fora do Photografia Pastore, que o fotógrafo realizou a parte mais marcante de sua obra: a fotografia de rua.

Com sua câmara portátil, Pastore saía às ruas e captava "os mal-estares da 'dita' sociedade do bem estar ${ }^{184 ", ~ a d o t a n d o ~ u m ~ p o n t o ~ d e ~ v i s t a ~ o p o s t o ~ a o ~ d a s ~}$ revistas ilustradas.

Pastore trouxe à tona aspectos conflitantes da sociedade paulistana da época, ao flagrar os tipos populares das ruas, ao invés dos membros da burguesia, que figuravam nos instantâneos das publicações ilustradas. Dessa forma, a fotografia de Pastore não integrava aquela que era corrente no Brasil no período, a qual buscava “(...) enfocar (...) padrões culturais europeus, sem evidências de contraste que pudessem macular essa imagem idealizada ${ }^{185}$."

Assim, o olhar de Pastore com relação a São Paulo é aquele do imigrante engajado no intuito de entender a cidade que escolhera viver, interessado em conhecer seus tipos, em captar o lado humano da capital repleta de imigrantes, operário, de subempregados, engraxates, meninos de pés descalços, negros, carregadores de malas e mascates, que movimentavam o cotidiano das ruas da cidade.

\footnotetext{
${ }^{183}$ Conforme consta da dissertação de Atílio José Avancini (op.cit.), o número 9 A da revista A Vida Moderna apresenta o seguinte anúncio: "Todas as pessoas que tomarem uma assignatura para o ano de 1914, concorrerão ao nosso sorteio de $\mathrm{R} \$ 12.500 \$ 000$, em diversos prêmios, como abaixo fica discriminado. Além do sorteio, offerecerá esta empreza, aos assignantes de anno, uma finíssima cigarreira de prata alemã cheia de cigarros Castellões, dando-lhes o direito de tirarem gratuitamente os seus retratos na Photographia Pastore, Rua Direita n.24 recebendo um exemplar artístico em cartão de $0.24 \times 0.18$."

${ }_{184}^{184}$ Atílio José Avancini. op. cit. p. 80.

185 Idem.ibidem.
} 
Na fotografia Sem Título, com data atribuída de 1910, [llustração 1.29], Pastore flagra três meninos observando a passagem de uma carroça puxada a cavalo. Observe-se o detalhe dos pés descalços do rapazinho que carrega um menino nas costas e apóia os joelhos sobre a quina da calçada (à direita da fotografia), e do garoto que está sentado na calçada olhando na direção da carroça (à esquerda da fotografia). Nesta fotografia, dois instantes da cidade: os meninos que exercitam sua infância disputando, de alguma maneira, o espaço de circulação do trabalho e da mercadoria.

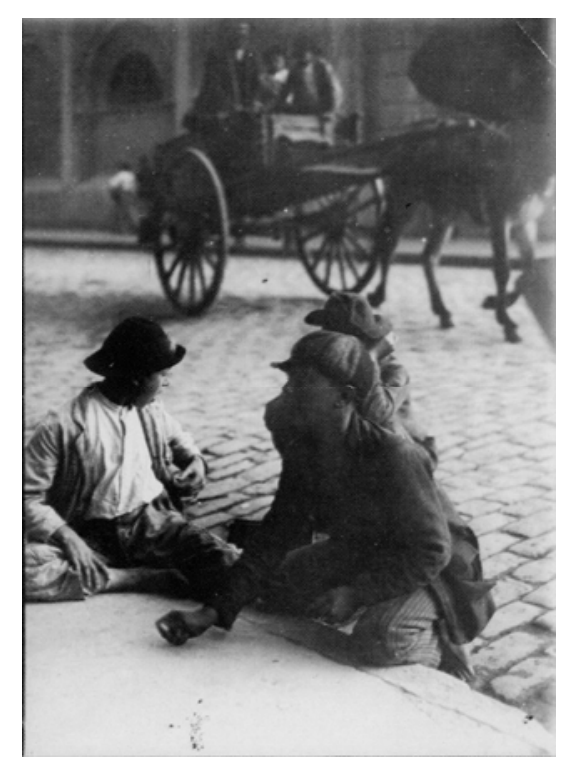

Ilustração 1.29: Vincenzo Pastore. Sem título. c.1910. Acervo do Instituto Moreira Salles.

\section{$\S \S \S \S$}

Alguns aspectos aproximam a fotografia de rua de Vincenzo Pastore à de German Lorca, como é possível observar em Sem Título, de Pastore (c.1910) e A Procura de Emprego ${ }^{186}$, de Lorca, (1950) [llustração 1.30].

\footnotetext{
${ }^{186}$ Esta fotografia voltará a ser analisada no Capítulo 3, desta dissertação.
} 

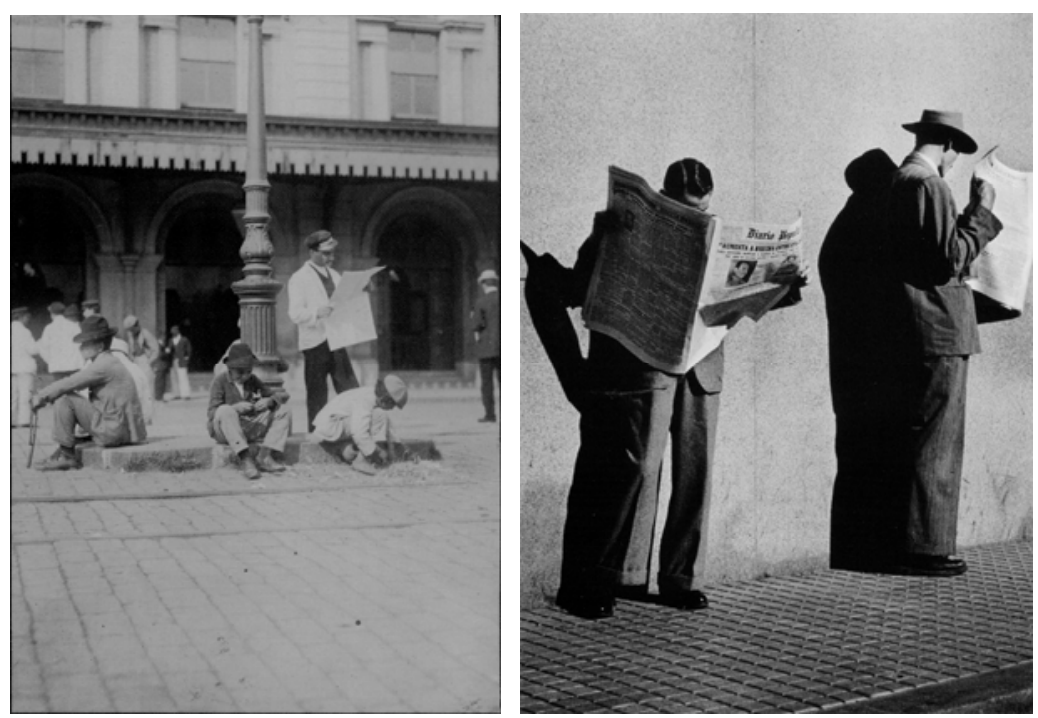

Ilustração 1.30: Vincenzo Pastore. Sem título, c. 1910 (à esquerda). Acervo do Instituto Moreira Salles. German Lorca, A Procura de Emprego, 1950. Coleção Museu de Arte Moderna de São Paulo.

Antes de qualquer ponderação torna-se necessário ter em vista os contextos de Pastore e Lorca, pertencentes a momentos diversos tanto do desenvolvimento da cidade de São Paulo quanto da própria fotografia brasileira.

A situação em que Vincenzo Pastore está inserido é o período em que São Paulo efetivamente se transforma numa proto-metrópole e em que a fotografia se encontra ainda marcada pela foto de estúdio (retrato), pelo aparecimento das revistas ilustradas e pela realização da fotografia de rua.

German Lorca, por sua vez, pertence a um outro momento da historia paulista: quando aquela cidade grande transforma-se de fato em metrópole com todas as conseqüências dessa transformação. Por outro lado pertence a uma outra geração de fotógrafos, aquela que irá despontar nos anos 1940, quando a fotografia moderna toma impulso no Brasil. 
Na fotografia Sem Título, Vincenzo Pastore apresenta, em foco, um carregador de malas, vestindo casaco branco e boné, em pé, lendo jornal ao lado de um poste na Estação da Luz. Dois meninos, que brincam com o feno da rua, estão sentados na plataforma que sustenta o poste, além de um homem negro, de terno e chapéu, com os braços esticados sobre os joelhos. Em segundo plano, na direção desse homem negro e formando uma diagonal com o carregador do primeiro plano, nota-se a presença de outros três carregadores conversando. Todos vestem o casaco branco e o boné observado naquele que lê o jornal.

Em A Procura de Emprego, German Lorca mostra dois homens lendo jornal. Ambos trajam terno e um deles usa chapéu. O homem sem chapéu segura o jornal de um modo que deixa bem visível o nome "Diário Popular".

Em primeira instância, o jornal é o elemento que une essas duas fotografias: tanto em um caso como no outro, o seu aparecimento possibilita enxergar aspectos do contexto sócio-cultural das épocas em que as fotografias foram realizadas.

Em Pastore é possível observar divergências dentro de uma mesma classe social: o carregador alfabetizado em contraposição aos outros carregadores, aos meninos de rua e ao negro. Já em Lorca o jornal simboliza o desenvolvimento da sociedade moderna e, ao mesmo tempo, a situação do trabalhador no período de grande transformação da cidade de São Paulo.

O enquadramento que cada fotógrafo realiza é outro aspecto a ser considerado. 
Em Pastore, o assunto da fotografia, ou seja, - o carregador de malas lendo jornal - é visto pelo fotógrafo sob a perspectiva de um plano aberto. Desse modo ele capta um fato (o carregador de malas que lê jornal), as ações que aconteciam à sua volta (os meninos de rua, o negro e os outros carregadores de malas) e o local onde tudo ocorreu (a Estação da Luz), características de uma fotografia documental.

Devido ao plano aberto, a rua de paralelepípedos em primeiro plano, ganha um espaço importante na fotografia: é a rua que conduz o olhar do observador para o carregador de mala que lê o jornal e seu entorno.

Em A Procura de Emprego, Lorca apresenta a abordagem característica de uma fotografia que quer ir além do mero registro do cotidiano e isso pode ser percebido por algumas estratégias usadas pelo fotógrafo. O corte utilizado por ele evidencia essa abordagem: o enquadramento se fecha em torno dos dois homens que lêem o Diário Popular. Os únicos outros elementos que se observam na fotografia são os jornais, a parede e a calçada, embora o negativo da fotografia mostre mais dados ${ }^{187}$.

Desse modo, Lorca emoldura somente o detalhe que vem ao encontro de sua intenção quanto à abordagem da fotografia e estabelece a seguinte estrutura dentro de um mesmo plano: a calçada de pastilhas é vista com relação à parede a qual ampara os homens lendo o Diário Popular, que constituem o assunto da fotografia, e reflete suas sombras ${ }^{188}$.

A sombra dos homens na parede, não observada nas outras pessoas da fila do original, merece um capítulo à parte: confere a plasticidade que eleva a

\footnotetext{
${ }^{187}$ A fotografia original de A Procura de Emprego será apresentada no capítulo 3.

188 Não devemos perder de vista que Pastore lança mão de recurso similar em sua fotografia: ao invés da calçada, a fotografia de Pastore utiliza a rua para estruturar a leitura da imagem. Nesse sentido, a rua de Pastore exerce um papel semelhante à calçada de Lorca, embora de outra forma. A rua de Pastore antecede o assunto da fotografia, diferente da calçada de Lorca que está no assunto.
} 
imagem à categoria de fotografia-artística, assim como o corte, conceito que despontaria no contexto da fotografia moderna no qual Lorca estava inserido.

\section{$\S \S \S \S \S$}

\section{CAPÍTULO 2: Menina na Chuva - momento decisivo ou encenação?}

German Lorca se insere no contexto da fotografia amadora paulistana da década de 1950 do século $X X$, quando os fotógrafos já tinham à sua disposição as câmeras portáteis de $35 \mathrm{~mm}$, como a Leica.

Esse tipo de câmera - vendida a partir dos anos 1920 - iria revolucionar a história da fotografia por suas possibilidades técnicas: caracteriza-se pela leveza, pela lente da objetiva (de boa luminosidade), pela portabilidade, pelo clique silencioso, pela versatilidade e, principalmente, pela discrição, fato que tornava viável ao fotógrafo fazer a fotografia sem que fosse percebido pelo fotografado $^{189}$.

As câmeras $35 \mathrm{~mm}$ seriam empregadas no fotojornalismo e nas diversas práticas do fotoamadorismo, como a fotografia de rua. Por sua qualidade técnica e características do filme, a câmera $35 \mathrm{~mm}$ traz a real possibilidade de se flagrar um fato, muito embora com as primeiras câmeras de mão do século XIX captar um instantâneo já tivesse começado a se tornar uma realidade.

\footnotetext{
${ }^{189}$ AVANCINI, Atílio José. Em flagrante: Leitura de fotografias de rua do cotidiano da cidade de São Paulo nas duas primeiras décadas do século XX. Dissertação de mestrado apresentada à Escola de Comunicações e Artes da Universidade de São Paulo, São Paulo, 1999 e SOUSA, Jorge Pedro. Uma história crítica do fotojornalismo Ocidental p. 73.
} 
Para o fotojornalismo, a possibilidade do flagrante reafirma a idéia de testemunho. Para a fotografia amadora, amplia-se o campo de experimentações com a possibilidade de, com um clique rápido (snapshot) e silencioso, flagrar as mais diversas situações.

No entanto, apesar da real possibilidade de realizar um flagrante, tanto no fotojornalismo como na fotografia amadora serão encontrados casos de falseamentos de flagrante (pseudoflagrante) e de controvérsias com relação à autenticidade ou não do fato flagrado.

\section{O flagrante e o pseudoflagrante no fotojornalismo do século XX na Europa e \\ Estados Unidos}

Com a chegada do século XX, novas possibilidades técnicas se abrem para a fotografia. Nesse século ficarão para trás as dificuldades técnicas enfrentadas pelos fotojornalistas oitocentistas como, por exemplo, a mobilidade comprometida do fotógrafo, devido ao uso das pesadas câmeras com tripés, em acontecimentos como as guerras, ou, ainda, quanto aos problemas relativos à velocidade de obtenção/revelação da imagem.

O século XX fará da prática do flagrante uma possibilidade concreta, quando chegam ao mercado as câmeras portáteis tipo $35 \mathrm{~mm}$ que propiciarão: agilidade de locomoção do fotojornalista no evento, a exploração de diversos ângulos e velocidade no tempo de captação da imagem, fatores primordiais para a realização de um flagrante. Dependendo do local do acontecimento, o 
fotógrafo poderia até dispensar o uso do flash ${ }^{190}$, graças aos variados tipos de objetivas permutáveis existentes para esse tipo de câmera.

Em paralelo a esse contexto, novas bases de veiculação da imagem fotográfica nas revistas e jornais ilustrados vinham sendo praticados pelo fotojornalismo alemão desde 1910 como, por exemplo, o fato de se conferir à fotografia, um peso maior que o texto e a valorização de ensaios autorais.

Para se ter uma idéia, em Julho de 1914, quando os jornais alemães anunciavam o "estado de guerra":

“(...) existiam por volta de 20 semanários ilustrados com circulação de mais de 1,5 milhões de exemplares, assim como 12 suplementos ilustrados semanais de jornais diários, os quais não mais se utilizavam de imagens em halftone, com circulação de 1,7 milhões de exemplares. A fotografia não era mais um simples acompanhamento de um texto, mas sim o componente principal de uma reportagem. Na apresentação de um tópico, imagem e texto eram um só corpo impressos em página inteira ou dupla. Além disso, não eram apenas veiculadas as fotografias individuais de diferentes fotógrafos justapostas, como também séries em ensaios fotográficos de um único fotógrafo, como a reportagem sobre o 'Hall de Imigração em Hambrugo' de Johann Hamman, publicado no Leipziger Illustriten Zeintung de 27 de Fevereiro de 1908(... $)^{191 "}$

\footnotetext{
190“Em 1925 é inventado por Paul VierKöter o flash de lâmpada. Em 1929 esse flash é aperfeiçoado por Ostermeier, que introduz um metal refletor na lâmpada. Os fotojornalistas em pouco tempo adotaram o modelo, substituindo o flash de magnésio. O novo flash fez sua estréia nos Estados Unidos, com a foto do presidente Hoover assinando a Lei de Apoio aos Desempregados". Cabe lembrar que o flash de magnésio possuía uma luz ofuscante e um odor desagradável. Ver Jorge Pedro SOUSA, op. cit. p. 73.

${ }^{191}$ Tradução livre: "At the time, there were some 20 illustrated weeklies with a circulation of more than 1.5 million, as well as, twelve weeklly illustrated supplements to daily newspapers which did not themselves carry halftone pictures, with a ciruculation of more than 1.7 million. Photographs were no longer the accompaniment to a text, but the main component of the report. In presenting a topic, picutures and texts were united and spread over a full or double page. Not only were individual by different photographers juxtaposed, but also series of photos for pictorial features by a single photographer, such as the report on the 'Emigration Halls in Hamburg' by Johann Hamman, published in the Leipziger Illustriten Zeitung of 27 February 1908." Ver WEISE, Bernd. Photojournalism from the first World War to the Weimar Republic. In: KRUSE,Petra; WILLINGHÖFER, Helga (coord.) German Photography 1870-1970. Bonn: Catálogo da exposição, 1997. trad. Dumont. p. 52
} 
A prática desses novos parâmetros fará surgir o fotojornalismo moderno na Alemanha e terá impulso durante os anos de 1918 a 1933, que compreendeu o período da República de Weimar:

A derrubada do império alemão pela revolução da classe operária em novembro de 1918 sacudira consideravelmente a velha hierarquia social. O desafio fundamental que a existência dos Conselhos de Operários e Soldados representavam nos anos de 1918/19 para a dominação dos latifundiários, industriais, oficiais do exército e escalões superiores do funcionalismo público, os esteios da 'monarquia guilhermina', tinham sido canalizados pela socialdemocracia para o leito de uma solução de compromisso. A história desse compromisso configura a história da República de Weimar ${ }^{192}$.

\section{Dentro desse contexto:}

(..)o crescimento rápido das publicações ilustradas já existentes e o surgimento de muitas novas publicações (Kölnische Illustrierte, Arbeiter-Illustrierte Zeitung, Müncher Illustrierte Presse, Deutusche Ilustrierte, Illustrierter Beobachter, para mencionar apenas as mais conhecidas) é um fenômeno típico dos anos $20^{193}$.

No cerne desse fenômeno de crescimento estará a fotografia que "passou a ser um dos fatores mais importantes do serviço de transmissão de notícias $^{194 ”}$.

No final dos anos 1920, a fotografia fazia parte da nova forma de relato fotográfico na reportagem, baseado, principalmente, na "legibilidade fácil e no

\footnotetext{
${ }^{192}$ Ver A fotografia na República de Weimar. Catálogo da exposição realizada pelo Instituto de Relações Culturais com o Exterior (IFA), Stutgart. Realização no Brasil: Secretaria de Estado da Cultura, Paço das Artes e Goethe Institut., p. 4. ${ }^{193}$ Idem. ibidem.

${ }^{194}$ Idem. ibidem. p. 5.
} 
poder sugestivo das imagens ${ }^{195 " . ~ O b j e t i v a v a-s e ~ u m a ~ u n i d a d e ~ g r a ́ f i c a ~ p l a n e j a d a ~}$ de texto e imagens:

(...)os temas das ilustrações passavam para o plano da linguagem e as imagens continuavam a argumentação do texto: uma unidade de texto e imagens como o desenvolvido pelo, simultaneamente, nascente filme sonoro ${ }^{196}$.

Nesse decurso, a reportagem fotográfica das revistas e jornais ilustrados alcançaria um patamar de respeito nos anos 1930, quando se tornaria um recurso expressivo e decisivo do fotojornalismo moderno.

Os primeiros repórteres fotográficos alemães foram Alfred Eisenstaedt, Wolfgang Weber, Umbo, Martin Munkacsi, Harold Lechenperg, Felix H. Man, Tim Gidal e Kurt Hübschman, além de Erich Salomon, que trabalharam para revistas como a Münchner Illustrierte Presse e Berliner Illustrirte Zeitung, por exemplo.

Será com Erich Salomon, jurista que tomou o jornalismo fotográfico como profissão em 1928, considerado o "pai do fotojornalismo moderno", que se difundirá a idéia de candid photography ${ }^{197}$ [Ilustração 2.1], a qual corresponderá aos flagrantes de personalidades em acontecimentos sociais e políticos, realizados por Salomon:

(...) Erich Salomon, com seus estratagemas e hábeis subterfúgios foi quem captou a imaginação do público. Alimentada em parte por seu próprio gosto em relatar suas

\footnotetext{
${ }^{195}$ Idem. ibidem, p. 6

${ }^{196}$ Idem. ibidem.

${ }^{197}$ A palavra candid em inglês siginifica franco. O termo candid photography deriva da expressão candid camera (câmera escondida), utilizada pelo diretor da revista londrina The Graphic para designar a técnica de Salomon que costumava esconder a câmara para fotografar. O fotógrafo inglês Paul Martin, que atuou como amador no final do século XIX e início do século XX, seria considerado um dos precursores dessa categoria. Ver SOUSA, Jorge Pedro. op. cit. p. 51 e WESTERBECK, Colin; MEYEROWITZ, Joel. Bystander: A history of street photography. Boston: Bulfinch Press, 2001. p. 96, 98 e 103.
} 
aventuras e todo o folclore acerca das vicissitudes que atravessava para conseguir uma fotografia. Chapéus e pochetes não eram os únicos meios que usava para esconder sua câmera. Obteve um primeiro plano do Presidente Hoover em um banquete em Washington usando um arranjo floral que estava na mesa como camuflagem. Uma tipóia em seu braço Ihe permitiu obter a primeira fotografia da Corte Suprema dos Estados Unidos em sessão $(\ldots)^{198}$.

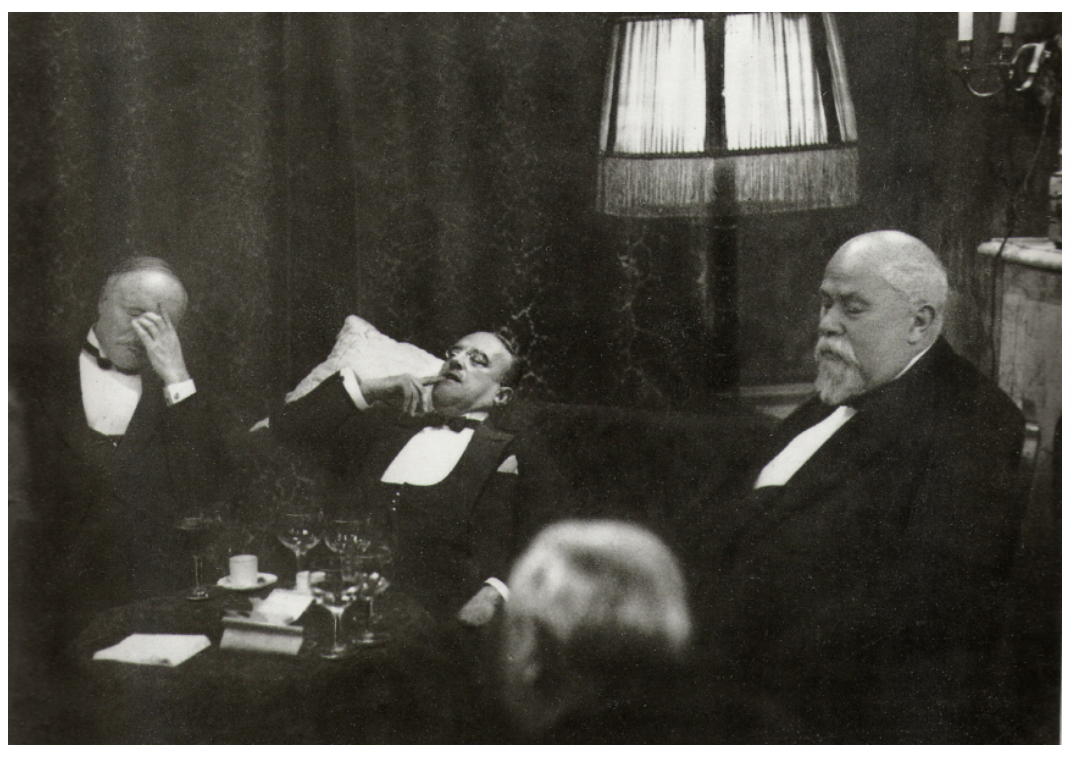

Ilustração 2.1: Candid Photography de Erich Salomon: Ministros Alemães e Franceses Em uma Sessão Noturna Por Ocasião da Conferência de Haager, 1930.

Dessa forma, Salomon se tornaria conhecido, fundamentalmente, por registrar políticos em acontecimentos sociais em atitudes espontâneas, inovando nesse tipo de registro: até o início de suas atividades as fotografias de acontecimentos sociais, principalmente envolvendo políticos, eram totalmente posadas ${ }^{199}$.

\footnotetext{
${ }^{198}$ Tradução livre: “(...) Erich Salomon, con sus estratagemas y hábiles subterfugios, fue el que captó la imaginación del público. Alimentada en parte por su propio gusto en relatar sus aventuras, todo un folklore acerca de las vicisitudes que atravesaba para conseguir una fotografía. Sombreros y valijas attaché no eran los únicos medios que usaba para esconder su cámara. Le tomó un primer plano al Presidente Hoover en un banquete en Washington usando un arreglo floral que estaba en la mesa como camouflage. Una correa fijada a su brazo le permitió obtener la primera fotografía de la Corte Suprema de Estados Unidos en sesión(...). Ver texto de Peter Hunter-Salomon (pseudônimo de Otto Erich Salomon, filho primogênito de Erich Salomon) no site da Agência de Imprensa/Banco Fotográfico Comesaña: http://www.comesana.com/salomon.php

${ }^{199}$ Embora Erich Salomon tenha mencionado em seu livro Contemporâneos célebres em instantes não vigiados, publicado em 1931, que uma de suas propostas seria explorar regiões até o momento inexploradas pelo fotojornalismo,
} 
Erich Salomon teria usado diversos tipos de câmera durante a sua trajetória. No início, a Contessa Nettel, de $13 \times 18 \mathrm{~cm}$, que considerava grande para fazer suas "fotografias escondidas". Depois, a Ermanox, utilizada até por volta do início dos anos 1930 quando passou a fotografar com a câmera Leica.

A Leica, devido ao filme perfurado nas bordas, possibilitava-lhe registrar acontecimentos em uma série de tomadas seqüenciadas ${ }^{200}$, obtidas de maneira muito rápida. Um exemplo é a seqüência fotográfica que realizou da reunião noturna dos ministros alemães e franceses por ocasião da conferência em Haager, à qual pertence a foto da llustração $2.1^{201}$.

A estética fotográfica obtida por Erich Salomon - resultado da tomada das fotografias em condições naturais - e a atenção para captar o instante em que o fato acontece - contribuiria para a idéia de "momento decisivo" que seria praticada, principalmente, por Henri-Cartier Bresson ${ }^{202}$.

Com relação a importância da obtenção de uma fotografia no momento em que o fato acontece, Salomon observa:

A atividade de um fotógrafo de imprensa que quer ser mais que um artesão é uma luta contínua pela sua imagem. Tal como o caçador está obcecado pela sua paixão de caçar, também o fotógrafo está obcecado pela fotografia única que quer obter (...) É

em uma referência a realização de fotografias em lugares exóticos. Ver catálogo da exposição $A$ fotografia na República de Weimar. op. cit. p. 6. Segundo o autor Jorge Pedro Sousa, "Nos primeiros tempos do novo fotojornalismo, para se obter sucessso nas fotografias em interiores por vezes era necessário recorrer a placas de vidro, mais sensíveis, e proceder à revelação das placas em banhos especiais. A profundidade de campo também era muito limitada, pelo que o cálculo das distâncias tinha de ser feito com muita precisão, o que dificultava a vida do fotógrafo. Também era preciso usar tripé, incômodo e difícil de esconder(...)". Ver SOUSA, Jorge Pedro. op. cit. p. 75.

${ }^{200}$ Um dos aspectos que conferiram modernidade ao fotojornalismo foi a possibilidade de obtenção de seqüências devido à características das câmaras $35 \mathrm{~mm}$, principalmente a Leica, que utilizava filme flexível (a Ermanox, lançada no mesmo ano que a Leica,1924, empregava negativos de vidro de pequeno formato). Segundo o autor Jorge Pedro Sousa, no início do fotojornalismo moderno "(...) Raramente se conseguiam obter várias fotos de um mesmo tema, pelo que a que se obtinha devia 'falar por si'(...)". Ver SOUSA, Jorge Pedro. op. cit. p. 75.

${ }^{201}$ No livro "Erich Salomon - Photographien 1928-1938" (Schirmer/Mosel, 2004), na página 117, há uma reprodução de 15 imagens dessa seqüência que mostra desde os políticos em franco debate até o seu gradual cansaço que culmina com a última fotografia (a reproduzida na llustração 2.1), na qual os políticos já estão tão esgotados que cochilam.

${ }^{202}$ A atenção para a captação do instante passa a ser observada a partir da possibilidade de se realizar fotos seqüenciadas de um mesmo tema, como foi o caso de Erich Salomon. "Assim, começa a insinuar-se, com força, no 'fotojornalismo do instante', a noção do que, mais tarde, Cartier-Bresson classificará como "momento decisivo". Ver SOUSA, Jorge Pedro. op, cit. p. 75 
preciso lutar contra (...) a administração, os empregados, a polícia, os guardas(...). É preciso apanhá-las [as pessoas] no momento preciso em que elas estão imóveis $(\ldots)^{203}$.

Essa luta pela fotografia única iria corresponder a uma necessidade que surgiria a partir da competição entre as revistas ilustradas alemãs.

O conceito de fotografia "única e ultra-secreta" nasce no âmbito da Revista Berliner Illustrirte Zeitung (BIZ) - da qual Salomon era o principal colaborador - e inventado por seu editor, Kurt Korff, que até permitiria a publicação de fotografias encenadas contanto que passassem por "ultrasecretas" ${ }^{204}$.

E foi esse tipo de fotografia que Erich Salomon muitas vezes produziu. Apesar de ter-se tornado conhecido por suas "fotografias cândidas", Salomon acabará por se utilizar, em algumas situações, do expediente de forjar um flagrante em nome da publicação da fotografia que demonstrasse o "furo de reportagem".

Esse foi o caso das fotografias que o autor realizou das salas de jogo do Cassino de Monte Carlo, em abril de 1929, que foram feitas antes do horário de funcionamento das salas, com os funcionários do Cassino posando como se fossem os jogadores habituais: “(...)A administração do cassino não tinha autorizado que se fotografassem os freqüentadores durante o período de abertura. O público desconhecia-o. $\mathrm{E}$ as fotos passaram por aquilo que não eram $^{205 "}$.

\section{$\S \S \S \S \S$}

\footnotetext{
${ }^{203}$ Idem, ibidem. p. 78 e SALOMON, Erich. Berühmte Zeitgenossen in unbewachten Augenblicken [Contemporâneos célebres fotografados em momentos inesperados]. Schirmer/Mosel Mündchen, 1978 (publicado originalmente em 1931).

${ }^{204}$ Ver SOUSA, Jorge Pedro. op. cit. p. 80.

${ }^{205}$ Idem. ibidem, p. 79.
} 
A partir dos anos 1930, conquistam relevância histórica por sua contribuição para o desenvolvimento do fotojornalismo moderno: Carl Mydans, Robert Capa, Henri Cartier-Bresson, Margaret Bourke-White, André Kertész, Brassaï, Martin Munkacsi, Robert Doisneau, David Douglas Duncan, George Rodger e David "Chim" Seymour, entre outros:

Concentrada predominantemente em Paris, essa geração vai cruzar-se com os fotógrafos que fugiam da Alemanha face ao avanço dos nazis: [Félix $\mathrm{H}$.] Man fica no Reino Unido a trabalhar com Lorant. [Alfred] Eisenstaedt e Fritz Goro fixam-se nos EUA, tendo vindo a integrar os quadros da Life, a partir de 1936 (Eisenstaedt colaborará com esta revista durante cerca de quarenta anos, tendo publicado mais de mil feature stories). [Robert] Capa, em 1933, dirige-se para Paris, depois de passar algum tempo em Viena e em Budapeste. [Erich] Salomon não teve essa sorte: judeu, apesar de se refugiar na Holanda, é apanhado pela guerra e deportado, tendo morrido em Auschwitz, em 1944. Na Alemanha, Heinrich Hoffman, amigo de Hitler, torna-se o fotógrafo todo-poderoso do regime, um regime que estimula uma fotografia ideológica e algo uniforme $e^{206}$.

Devido a esse cruzamento, os preceitos e a estética apresentada no fotojornalismo alemão moderno da República de Weimar passam a influir diretamente no modo de apresentar uma fotoreportagem em revistas ilustradas como a Life, que absorverá fotojornalistas alemães, a exemplo de Eisenstaedt, em seu quadro de colaboradores. Essa influência se estende à estética

\footnotetext{
${ }^{206}$ Antes de fixar-se no Reino Unido, Félix H. Man foi fotoreporter da revista Münchner Illustrierte Presse, cujo editor era Stefan Lorant (que recusava a encenação fotográfica), fomentador da foto-reportagem aprofundada sobre um único assunto (para quem Man também trabalharia no Reino Unido). Esse editor incentiva a realização de fotoreportagens sobre assuntos com os quais o público se identificava, deixando de focar as reportagens em temas com os quais estivessem envolvidas figuras públicas. Nesse âmbito Félix $\mathrm{H}$. Man realizou fotoreportagens sobre piscinas populares, combates de boxe, restaurantes e parques de diversão, e até a primeira fotoreportagem noturna. Alfred Eisenstaedt, antes de fugir para os EUA foi chefe da sessão de fotografia da Associeted Press em Berlim. Idem, ibidem. p. 77 e 81.
} 
fotográfica praticada pelos fotógrafos concentrados em Paris (além de Robert Capa, Henri Cartier-Bresson, por exemplo) e contribui para a formação das bases da noção de "humanismo francês ${ }^{207 " ~ n a ~ f o t o g r a f i a, ~ q u e ~ s e ~ f u n d a ~ d u r a n t e ~}$ as reportagens fotográficas, a partir da Guerra Civil Espanhola.

Primeira guerra do século XX a ter ampla cobertura fotográfica, a Guerra Civil Espanhola teve início em 1936 e durou até às vésperas da eclosão da II Guerra Mundial $^{208}$. Nesse embate:

a maior parte dos grandes fotógrafos que se deslocaram para a Espanha escolheu, sem hesitar, o lado dos Republicanos-lealistas, pois a sua causa atraía-os, no que tinha de romântico e desesperado, de utopia e solidariedade. Os casos de Capa, CartierBresson ou David Seymour são paradigmáticos ${ }^{209}$.

Essa atitude iria influir na acentuação de um determinado ponto de vista e a "'autocensura' motivada pelo empenho na causa e conseqüente postura perante o mundo, vai levar a que, na produção fotojornalística dessa guerra, pouco se veja das atrocidades cometidas pelo campo em que os fotógrafos atuavam ${ }^{210 " .}$

Fotógrafos espanhóis e estrangeiros cobriram a Guerra Civil Espanhola. Segundo Sousa, entre eles, os mais conhecidos foram Augustí Centelles, colaborador do La Vanguardia, de Barcelona, e José Suárez, que se tornaria

\footnotetext{
${ }^{207}$ Entendo por "humanismo francês" a proposta de fotógrafos desta nacionalidade que tinham como base a realização de fotografias, principalmente nas guerras, que mostrassem a ação com humanismo e sentimento. Para tanto os fotógrafos procuravam registrar a ação bem de perto de modo a transmitir tais idéias. A noção de humanismo estaria presente no trabalho dos "concerned photographers", grupo ao qual pertenciam muitos dos principais nomes do humanismo francês como Henri Cartier-Bresson, Robert Capa e André Kertesz, por exemplo, além de David Douglas Duncan, Bill Brandt, George Rodger, Martin Munkacsi, Brassaï, Robert Doisneau, Margaret Bourke-White, entre outros. A produção dos "concerned photographers" não era apenas destinada à imprensa, mas também a livros e exposições. A esse respeito ver SOUSA, Jorge Pedro. op. cit. p, 87 e 88.

${ }^{208}$ Idem, ibidem, p. 85. Também no fotojornalismo, a Guerra Civil Espanhola serviu de "laboratório de ensaio" para a II Guerra Mundial.

${ }^{209}$ Ver SOUSA, Jorge Pedro. op. cit. p. 85 e 86.

${ }^{210}$ Idem. ibidem. p. 86.
} 
colaborador da Life, tendo realizado o documental Mariñeros para o Governo Republicano. A fotógrafa Edith Tudor que, em 1938, fotografa a saga das crianças bascas refugiadas da Guerra para o Christian Science Monitor e Tina Modotti, também tiveram atuações destacadas durante a Guerra.

Porém, será com a que esse autor denomina de geração mítica composta por alguns dos fotógrafos do humanismo francês como Robert Capa, Henri Cartier-Bresson e David Seymour - que a cobertura fotográfica da Guerra Civil Espanhola receberá aportes pioneiros. Será, por exemplo, com a atuação do húngaro Robert Capa - pseudônimo de Andre Friedman -, na cobertura da Guerra que se debaterá a questão: "para informar deve 'mostrarse' ou 'sugerir-se,211?"

Também será Robert Capa quem realizará a fotografia que se tornou símbolo da Guerra Civil Espanhola denominada originalmente Soldado Republicano no momento de sua morte, Cerro Muriano, Setembro 5, 1936, [llustração 2.2], comumente conhecida como Morte de um Soldado Republicano.

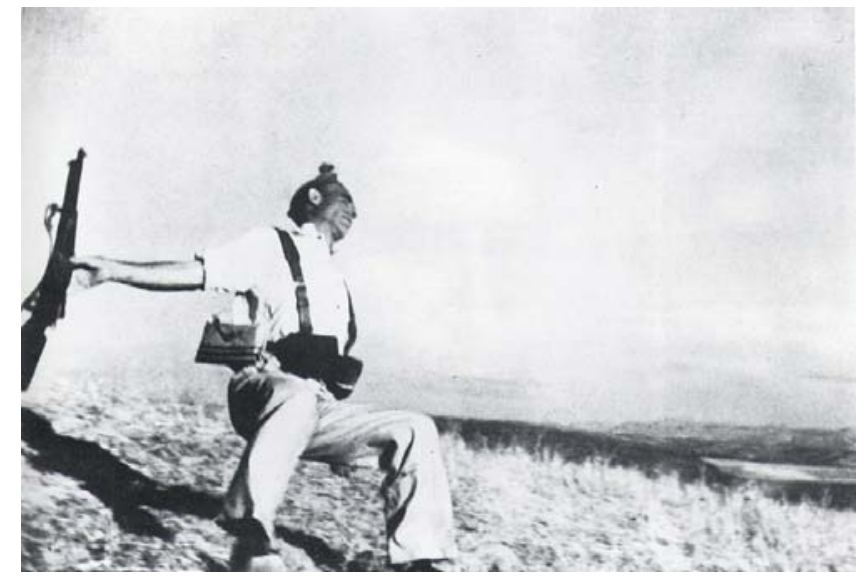

Ilustração 2.2: Robert Capa. Morte de um Soldado Republicano, $1936^{212}$.

\footnotetext{
${ }^{211}$ Idem, ibidem, p. 87.

${ }^{212} \mathrm{~A}$ agência Magnum Photos, à qual Robert Capa pertenceu, atualmente inclui na legenda dessa fotografia o nome de Federico Borrel Garcia, o soldado republicano que cai alvejado, como mostrará o estudo de Richard Whelan: Soldado Republicano (Federico Borrell Garcia)
} 
Segundo dados do historiador e biógrafo de Robert Capa, Richard Whelan, em 1975, essa fotografia teria sua autenticidade questionada ${ }^{213}$. Em seu ensaio, Whelan investiga as controvérsias sobre a possível encenação da fotografia Morte de um Soldado Republicano, surgidas desde então e que persistiriam até $1998^{214}$. O autor tomará como ponto de partida para a sua análise a reportagem da revista $V u^{215}$, na qual foi publicada Morte de um Soldado Republicano, realizando um estudo detalhado dessa fotografia. O historiador busca certificar-se, primeiramente, do local do acontecimento e em que condições ele ocorreu ${ }^{216}$. Seu estudo oferece também

http://www.magnumphotos.com/c/htm/FramerT MAG.aspx?Stat=Portfolio DocThumb\&V=CDocT\&E=2TYRYDI32L7S\& DT=ALB

${ }^{213}$ Refiro-me ao ensaio Proving that Robert Capa's "Falling Soldier" is genuine: a detective story (algo como Provando que a fotografia "Morte de um soldado Republicano" de Robert Capa é genuína: uma história de detetive), publicado na página da American Masters no site da "PBS" http://www.pbs.org/wnet/americanmasters/database/capa r3.html. Segundo esse ensaio de Whelan, em 1975 aventou-se a possibilidade de forja da ação na fotografia de Capa em um livro do jornalista britânico Phillip Knightley, intitulado The First Casualty: From the Crimeia to Vietnam; The War Correspondent as Hero, Propagandist, and Myth Make (New York: Harcourt, Brace, 1975). Knightley publicou nesse livro um depoimento de O. D. Gallagher, jornalista sul-africano, então correspondente do The London Daily Express que insinua que a fotografia Morte de um Soldado Republicano, de Robert Capa, fora forjada. O. D Gallgher teria dito a Knigtley que em determinado momento da guerra ele e Capa dividiram um quarto (sem especificar quando e onde), em um período em que pouca ação acontecia na guerra. Capa e outros fotojornalistas teriam reclamado com oficiais republicanos que assim eles não poderiam realizar nenhuma fotografia. Enfim, um oficial teria dito a eles que ordenaria a algumas tropas que fossem com Capa em algumas trincheiras das proximidades, para que encenassem algumas situações as quais pudessem ser fotografadas.

${ }^{214} \mathrm{Em} 1978$, o mesmo O.D. Gallagher (três anos depois de sua primeira declaração sobre a falsidade da fotografia de Capa), concederia uma entrevista a Jorge Lewinski que foi publicada no livro The Camara at War: a history of war photography from 1848 to the Present Day (Nova lorque: Simon \& Schuster, 1978), desse autor, na qual seria contraditório sobre as próprias afirmações a respeito da não autenticidade da fotografia Morte de um Soldado Republicano. De acordo com Whelan, em decorrência dessas inconsistências nos depoimentos a Knightley e Lewinski, o testemunho de Gallagher teria caído em descrédito e encerrado por ora a controvérsia. Contudo, a controvérsia sobre a autenticidade ou não de Morte de um Soldado Republicano continuaria até o mês de agosto de 1996 quando a jornalista britânica baseada na Espanha, Rita Grosvenor, escreveu um artigo sobre um espanhol chamado Mario Brotóns Jordá que reconheceu o soldado retratado na fotografia de Capa, como Federico Borrell García. Jordá teria inclusive confirmado nos arquivos do governo espanhol que Borrell García havia sido morto em Cerro Muriano, no dia 5 de Setembro de 1936. Em julho de 1998, quando acontecia uma exposição retrospectiva sobre a obra de Robert Capa, em Londres, o mesmo jornalista que publicou pela primeira vez o depoimento de Gallagher sobre a possibilidade de encenação na fotografia Morte de um Soldado Republicano - Phillip Knightley - escreveu um artigo descartando a descoberta de Brotón atestando que "A famosa fotografia é quase certamente falsa - Capa a encenou". Knightley chega a afirmar que Capa teria encenado a fotografia com Borrell García antes de sua morte. Ver WHELAN, Richard. Op. cit.

${ }^{215}$ Edição de 23 de setembro de 1936.

${ }^{216}$ Richard Whelan iria começar a constatar que Capa estava mesmo em Cerro Muriano, a partir de dados como os constantes de um livro The Spanish Cockpit (Londres, 1937), do jornalista francês Franz Borkenau. Nesse livro, Borkenau relata ter presenciado uma batalha próxima à vila de Cerro Muriano, na tarde de 5 de setembro, quando estava acompanhado de dois fotógrafos da revista $V u$, sem citar nomes (Hans Namuth e Georg Reisner, segundo a pesquisa de Whelan). De posse dessa informação, Whelan verifica as imagens realizadas por Namuth e Georg Reisner na $V u$ e reconhece nas fotografias de autoria de Capa, publicadas na mesma edição da Vu em que estava Morte de um Soldado Republicano, alguns dos mesmos soldados registrados por esses fotógrafos. Dessa forma, Whelan chega a conclusão de que Robert Capa estava fotografando no local naquele dia. Além disso, Richard Whelan checou essa possibilidade por meio das ampliações preservadas nos arquivos de Capa, marcadas com a seqüência numérica cronológica original e percebeu que tal seqüência pertencia àquela da série dos soldados refugiados em Cerro Muriano. O estudioso considera também as fotografias que antecedem o momento da morte de Borrell García, quando ele estava junto a um grupo de soldados, que pulavam uma vala entre dois montes.Na análise de Whelan, o soldado 
uma análise, sob o ponto de vista técnico, da postura do soldado em queda, a partir do parecer de um especialista em homicídio - o Capitão Robert L. Franks, detetive chefe de homicídio do Departamento de polícia de Memphis.

O parecer do especialista seria um dos fatores decisivos para que Whelan concluísse o que acreditava antes de iniciar sua pesquisa: a fotografia Morte de um Soldado Republicano é um flagrante autêntico. E isto porque, de acordo com o Capitão Franks, o soldado em questão - coronel Federico Borrel García -, estava morto quando caía e, portanto, não poderia se tratar de uma fotografia encenada.

O capitão constatou esse fato a partir da observação da posição dos dedos da mão do soldado, posicionada abaixo de sua coxa esquerda.

Segundo o capitão, o fato de os dedos estarem curvados em relação à palma demonstra que os músculos da mão do soldado estavam flácidos, constituindo um indício de que seu corpo não tinha mais vida. Para o capitão Franks, dificilmente alguém que simulasse a morte em um campo de batalha saberia que tal posição dos dedos seria necessária para tornar a fotografia realista: seria quase impossível para alguém vivo resistir ao reflexo de flexionar as mãos e estender os dedos na tentativa de equilibrar-se durante a queda.

Borrell Garcia teria caído e saído da tal vala, permanecendo em pé, próximo a sua borda. Robert Capa estaria posicionado dentro da vala de modo que seria possível fotografá-lo. No momento em que Capa disparava a fotografia, algum soldado da tropa inimiga, que devia estar escondido, abriu fogo. Borrell Garcia teria sido atingido no coração e morrido instantaneamente, como Capa captou na fotografia. Ver WHELAN, Richard. Op. cit. 


\section{$\underline{\text { O fotojornalismo e o momento decisivo de Henri Cartier-Bresson }}$}

O conceito de momento decisivo nasce no âmbito do fotojornalismo. A raiz deste conceito remonta à idéia de flagrante que começou a delinear-se durante a Guerra da Secessão, ainda no século XIX.

Noções que surgiram nesse decurso como a nova objetividade e a straight photography, que preconizavam a nitidez, a precisão e a recusa em mascarar as características técnicas da fotografia contribuíram como parâmetros estéticos para o que mais tarde seria definido como momento decisivo.

Contudo, será o desenvolvimento do fotojornalismo moderno na Alemanha, nos anos 1920, que impulsionará o chamado fotojornalismo do instante, precursor da idéia de momento decisivo. Para essa nova realidade, o registro do instante, do momento, torna-se fundamental, principalmente considerando que a candid photography de Erich Salomon já era amplamente divulgada. Nesse ponto, o público começava a interessar-se por encontrar nas reportagens das revistas ilustradas instantâneos da vida cotidiana, além de fotografias de personalidades flagradas em acontecimentos públicos.

Porém a definição de momento decisivo, da maneira como é entendida hoje, nasce no âmbito da Agência Magnum, criada em 1947, pelos fotógrafos Henri-Cartier Bresson, Robert Capa, George Rodger, David Seymour (Chim) e William Vandivert.

Esse conceito iria pressupor, a priori, que o sentido de uma imagem fotográfica depende de sua obtenção no momento crucial de sua configuração. 
A questão do momento decisivo se tornou notória com a atuação do fotógrafo francês Henri Cartier-Bresson, a partir dos anos 1930, quando adotou esse preceito como seu lema pessoal ${ }^{217}$. Para ele: "De todos os meios de expressão a fotografia é a única que fixa o instante preciso. Lida-se com coisas que desaparecem e que, uma vez desaparecidas, é impossível revive-las. Não se pode retocar o tema $(\ldots)^{218 "}$.

Essas e outras considerações que compõem o conceito de momento decisivo de Cartier-Bresson, são por ele observadas dentro da ótica do repórter fotográfico. Sob esse prisma, o fator primordial para a realização de uma fotografia é o olho do fotógrafo: a capacidade de perceber um fato a fim de poder fixá-lo por meio da câmera fotográfica. Bresson considera que a fotografia "é o reconhecimento da realidade de um ritmo de superfícies, linhas ou valores, o olho recorta o tema e a câmera não tem mais que fazer seu trabalho, que consiste em imprimir na película a decisão do olho ${ }^{219 "}$.

Para Cartier-Bresson o instante preciso seria aquele que "apresenta uma relação com a realidade profunda", o instante fugaz que traduz a essência de um acontecimento: "inspira-me, sobretudo, o desejo de reter em uma única imagem o essencial que surgia em uma cena ${ }^{220 " . ~}$

Segundo ele, diversos fatores imperam para que se obtenha e mostre o momento decisivo, desde o reconhecimento do fato, passando pelo reflexo do fotógrafo e sua conseqüente rapidez para captá-lo, intuição; até as relações entre as formas na composição: “(..)a fotografia é o reconhecimento

\footnotetext{
${ }^{217}$ Cartier-Bresson se dedicaria a refletir sobre o momento decisivo no livro Images a la sauvette - l'instant decisif, publicado em 1952, que foi traduzido para o inglês como The Decisive Moment. Atualmente esse texto pode ser encontrado também na coletânea Fotografiar del Natural, de Henri Cartier-Bresson (Editorial Gustavo Gilli, 2003) e no livro Photographers on photography de Nathan Lyons (New Jersey: Prentice-Hall, Inc, Englewood Ciffs; New York, The George Eastman House, 1966.)

${ }^{218}$ CARTIER-BRESSON. Henri. Fotografiar del Natural. Barcelona: Editorial Gustavo Gilli, 2003, p. 19

${ }^{219}$ Idem. Ibidem. p. 24

${ }^{220}$ Idem. Ibidem. p. 16
} 
simultâneo, em um mesmo instante, tanto da significação de um fato quanto da organização rigorosa das formas percebidas visualmente que conferem-lhe significado ${ }^{221 "}$.

Postas estas questões, pode-se entender o momento decisivo de Henri Cartier-Bresson como uma elaboração poética do flagrante, ou seja, como uma forma de composição pautada no ato de flagrar.

Nesse sentido, o momento decisivo de Henri Cartier-Bresson reforça o valor do flagrante como parâmetro fotográfico, principalmente considerando-se que lida com seu principal preceito: a agilidade do fotógrafo em registrar instantaneamente a cena fugaz e única.

German Lorca e Henri Cartier-Bresson: aproximações possíveis entre Menina na Chuva e Atrás da Estação Saint-Lazare

German Lorca e Henri Cartier-Bresson estão inseridos em contextos diversos: o primeiro desponta como amador no Foto-Cine Clube Bandeirante (São Paulo - Brasil), nos anos 1950, e o segundo no panorama internacional do fotojornalismo dos anos 1930.

Em tese, como pertencentes a universos distintos, com objetivos igualmente distintos, talvez não coubesse uma aproximação entre fotografias pontuais em suas produções, como Menina na Chuva (1950) e Atrás da Estação Saint-Lazare, (1932).

Porém, com o intuito de se refletir sobre a cultura visual ${ }^{222}$ na qual Lorca estava imerso, entre o final dos anos 1940 e início da década seguinte, tal aproximação torna-se primordial.

${ }^{221}$ Idem, ibidem. p. 29. 
Como foi apontado na Introdução, embora Lorca negue qualquer referência ao universo de Bresson quando realizou a fotografia Menina na Chuva, o fato dele ter participado como amador de diversos salões internacionais de fotografia e de discussões sobre os encaminhamentos da fotografia moderna (tanto dentro do Foto-Cine Clube Bandeirante quanto fora dele $^{223}$ ), coloca-o, de alguma forma atento ao debate internacional sobre a fotografia, na época. Nesse sentido, ele não teria como não ter entrado em contato com a produção do artista francês - e com as questões que ela trazia para a fotografia da época - mesmo que não se desse conta disso.

\title{
A fotografia moderna no Brasil nos anos 1950: fotoamadorismo e
}

\author{
$\underline{\text { fotojornalismo }}$
}

Os anos 1950 no Brasil caracterizaram-se pelo nacionalismo, vigoração da democracia e estabelecimento da classe média ${ }^{224}$.

Foi nessa década que, cidades como São Paulo e Rio de Janeiro, principalmente, impulsionadas pelo desenvolvimento industrial,

${ }^{222}$ De acordo com os autores Jessica Evans e Stuart Hall "a disseminação do termo 'cultura visual' é geralmente atribuído a Svetlana Alpers, quem em 1972, também foi a primeira a usar o termo 'nova história da arte' em material impresso". Alpers emprega o termo "cultura visual" para explicar seu método de análise da pintura holandesa por meio dos recursos visuais relacionados à prática desse tipo pintura: o microscópio, a câmera obscura, os mapas. A respeito da fotografia, os autores citam um exemplo do que significaria cultura visual nesse âmbito: "Não se pode entender, por exemplo, as práticas do flagrante na fotografia amadora ou levar em conta o severamente restrito 'estilo' que ele [fotógrafo] ou ela [fotógrafa] produz, sem também considerar como essa prática se entrecruza com a indústria de manufatura da câmera e do filme fotográfico, com o desenvolvimento e processamento de companhias, com as relações nas sociedades modernas entre trabalho e lazer, e, além disso, com conceitos históricos específicos de identidade, crenças e habilidades do fotógrafo". Tradução livre: "One cannot understand, for example, the practices of the amateur snapshot photographer, nor account for the severely restricted 'style' of images he or she typically produces, without also considering how this pratice intersects with the camera and film manufacturing industry, with the developing and processing companies, with the relationships in modern societies between work and leisure, with definitions, idealizations and activities of family, life, and, not least, with localized and historically specific gendered conceptions of the identity, beliefs and skills of the photographer". Ver EVANS, Jessica; HALL, Stuart. What is visual culture? In: EVANS, Jessica; HALL, Stuart (org.) Visual Culture: the reader. Londres: Sage Publications, $2002\left(3^{\mathrm{a}}\right.$ edição).

${ }^{223}$ Ainda neste capítulo serão mostrados outros elementos que atestam que a fotografia moderna em São Paulo não estava restrita apenas ao Foto-Cine Clube. Chamo a atenção para a presença dessa fotografia na Revista Íris e $O$ Cruzeiro.

${ }^{224}$ Segundo Helouise Costa e Renato Rodrigues da Silva "A formação de um mercado interno, devido ao afluxo de capitais estrangeiros, pode facilmente ser verificada pela maior definição e estratificação das classes urbanas sociais. Ao lado de um empresariado nacional e de um proletariado urbano, estabeleceu-se definitivamente a classe média no horizonte socioeconômico e cultural do país. Ver COSTA, Helouise \& SILVA, Renato Rodrigues A fotografia moderna no Brasil. São Paulo: CosacNaify, 2004, p. 33. 
experimentavam um momento de franco crescimento urbano. Nesse período, se assistia ao progresso da construção de monumentos que se tornariam marcos históricos, como a Catedral da Sé ${ }^{225}$, em São Paulo, conforme podemos observar em uma fotografia de autoria do próprio German Lorca [llustração 2.3].

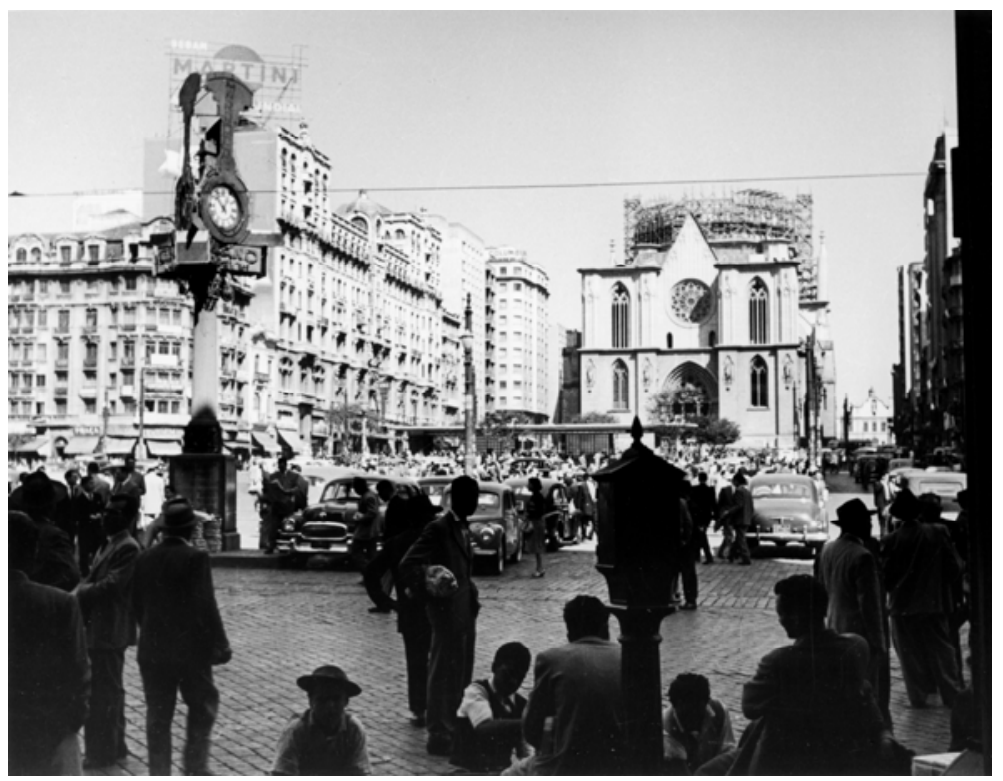

llustração 2.3: German Lorca. Catedral da Sé, 1952. Coleção Museu de Arte Moderna de São Paulo.

\section{Segundo Felipe Chaimovich:}

Os anos cinqüenta abrem-se com a eleição de Getúlio Vargas para a presidência da República, com 49\% dos votos válidos. Embora tivesse governado o país como ditador, entre 1937 e 1945, ele retornava em 1950 como defensor do legalismo, abrindo a primeira década da história nacional em que a democracia vigorou de fato. Com Vargas

\footnotetext{
${ }^{225}$ A Catedral da Sé começou a ser construída no dia 6 de julho de 1913, quando foi realizada a solenidade na qual o arcebispo Dom Duarte Leopoldo e Silva, benze uma pedra e a coloca no terreno delineado para a construção da Catedral: "Está lançada a primeira pedra da Catedral de São Paulo. É um monumento comemorativo de fé, comemorativo de patriotismo" - diria o orador oficial da solenidade, Dom Sebastião Leme. O projeto da Catedral foi desenvolvido pelo engenheiro Maximiliano Emílio Hehl, professor de arquitetura da Escola Politécnica de São Paulo e de Arte Sacra no Seminário Provincial. A Catedral só seria inaugurada em 25 de janeiro de 1954 - quarenta e um anos depois do lançamento de sua pedra fundamental - por ocasião da comemoração do IV Centenário de São Paulo, embora inacabada. Em fevereiro de 1999, o Ministério da Cultura recebe o projeto de restauro da Catedral da Sé. Em setembro de 2002 a Catedral é reaberta, restaurada e concluída. Ver DELELLIS, Rosana. Catedral da Sé: Arte e engenharia na recuperação do patrimônio. Rosana Delellis, Artur Lescher, latã Canabrava; [tradução inglês], Camilo Rocha. São Paulo: FormArte, 2002.
} 
retorna o projeto nacionalista iniciado por ele mesmo, à frente da revolução de 1930. A situação do Brasil como produtor agrário seria incompatível, por um lado, com a autonomia da nação perante os Estados Unidos e a Europa e, por outro, com a modernização das condições de trabalho dos brasileiros. A indústria, o sindicalismo e a nacionalização dos bens naturais deveriam reordenar o país e libertar a sociedade das forças retrógradas ${ }^{226}$.

O papel da indústria nesse processo de reordenação da sociedade encontra seu ápice no governo seguinte, o de Juscelino Kubitschek, que teve início em janeiro de $1956^{227}$.

O então presidente retoma o projeto nacionalista de Vargas e apresenta um plano desenvolvimentista de trinta metas para os cinco anos de governo visando atingir cinco áreas principais: energia, transportes, alimentos, além de indústrias de base e educação, segundo dados de Chaimovich.

O plano desenvolvimentista de Kubitschek culmina com a construção de Brasília, meta síntese de seu governo, a qual foi registrada por Thomas Farkas, oriundo do Foto Cine Clube Bandeirante, revelando "as feições da monumental obra da modernidade brasileira ${ }^{228 "}$.

Esse crescimento industrial e urbano que o país experimenta no pósguerra irá impulsionar o fotoclubismo, que terá grande desenvolvimento no período e se introduzirá no debate da modernidade:

De caráter elitista, o fotoclubismo, visava fazer da fotografia uma atividade artística. A condição do fotografo clubista, em termos gerais, era a do profissional liberal que, dono de uma situação financeira privilegiada, podia se dedicar à fotografia em suas horas

\footnotetext{
${ }^{226}$ Ver texto de Felipe Chaimovich no catálogo da exposição Cinqüenta 50. Museu de Arte Moderna de São Paulo: 04 de janeiro a 13 de março de 2005, curadoria: Felipe Chaimovich.

${ }^{227}$ Idem, ibidem. Getúlio Vargas suicida-se m 24 de agosto de 1954. Juscelino Kubitschek é eleito em 1955 com $36 \%$ dos votos válidos, tomando posse apenas em 31 de janeiro de 1956.

228 Idem. ibidem.
} 
vagas. Para esta classe média urbana em ascensão, carente de símbolos que a identificassem socialmente, o fotoclubismo veio bem a calhar, criando-lhe uma forte identidade cultural. O pequeno burguês agora é um artista ${ }^{229}$.

A prática do fotoclubismo tem início com a popularização da fotografia a partir de meados dos anos 1850, fato que despertaria o interesse de pessoas comuns em praticá-la - os fotógrafos amadores:

Com a popularização da fotografia, começam a proliferar em todo o mundo, principalmente na Europa e Estados Unidos, clubes e associações reunindo os praticantes da nova arte. Essas entidades uniam amadores, profissionais, artistas e técnicos, os primeiros nela encontrando um novo e fascinante meio de expressão artístico e os segundos, novos campos de experiência ${ }^{230}$.

Entre esses clubes e associações, segundo dados de Helouise Costa e Renato Rodrigues da Silva, os principais foram a Royal Photographic Society, de Londres, (1853); a Societé Française de Photographie, de Paris, (1854); o Camera Club, de Londres (1886) e a Fédération Nationale dés Societés Photographiques, da França.

No Brasil os clubes de mais destaque foram o Photo Club Brasileiro ${ }^{231}$, localizado no Rio de Janeiro, e o Foto Cine Clube Bandeirante, em São Paulo, embora a atividade fotoclubista tenha se propagado por várias cidades do país

\footnotetext{
${ }^{229}$ Ver COSTA, Helouise \& SILVA, Renato Rodrigues. Op. cit. Diferentemente da maioria dos fotógrafos amadores fotoclubistas, German Lorca não gozava de situação financeira privilegiada. Pelo contrário, Lorca residia em um bairro de classe média baixa, o Brás, e exercia o ofício de contador.

${ }^{230}$ Idem. ibidem.

${ }^{231}$ O primeiro clube carioca que se tem notícia foi o Photo Club do Rio de Janeiro, fundado em 1910. Contudo esse clube existiu por pouco tempo. Ver COSTA, Helouise \& SILVA, Renato Rodrigues. Op. cit. p. 25.
} 
tais como Porto Alegre, Belo Horizonte, Recife, Vitória, Salvador, Aracaju, Fortaleza, Curitiba e Belém ${ }^{232}$.

O Photo Club Brasileiro, fundado em 1923, atuava, principalmente, voltado à estética pictorialista ${ }^{233}$ e liderou o movimento fotoclubista no Brasil até por volta do aparecimento do Foto-Cine Clube Bandeirante ${ }^{234}$, em 1939, que promoveria manifestações modernas na fotografia:

A fotografia moderna no Brasil, pela sua própria origem social, serviu como mecanismo de adequação da classe média às modificações que vinham sendo operadas na sociedade. Isso ocorreu nas décadas de 40 e 50, fruto da ação de um grupo de fotógrafos que atuou no Foto-Cine Clube Bandeirante e foi batizado pela crítica da época de Escola Paulista ${ }^{235}$.

\section{Entre os fotógrafos oriundos do Bandeirante, são considerados os} pioneiros da fotografia moderna brasileira: German Lorca, José Yalenti, Thomas Farkas e Geraldo de Barros, segundo dados de Costa e Rodrigues

Silva:

232 Idem, ibidem, p.23. Além de ter se espalhado "pelas pequenas e médias cidades da atual Região Sudeste, principalmente do estado de São Paulo, como Santos, Campinas, Santo André, São Carlos, São José do Rio Preto, Barretos, Jaú, Araraquara e Bauru. No estado do Rio de Janeiro havia fotoclubes em Nova Iguaçu, Niterói, Volta Redonda, Campos e Nova Friburgo".

${ }^{233} \mathrm{O}$ pictorialismo, um dos assuntos mais debatidos até hoje na fotografia, foi um movimento em torno da estética fotográfica que teve origem no século XIX. Consistia em intervir com pintura nas chapas fotográficas (calótipos e daguerreótipos) e torná-las o mais próximo da pintura. Mesmo depois do advento da câmara portátil, as fotografias ainda eram realizadas pautadas em preceitos da pintura. .A estudiosa Maria Teresa Bandeira de Mello classifica o pictorialismo como "anedótico", ou seja, aquele que apenas buscava imitar a pintura, e o "da forma". Este último "engajou verdadeiramente a fotografia em uma trajetória paralela à da pintura, inaugurando um campo de debates e promovendo um novo tempo para as artes visuais", nas palavras da autora. Jacob Polacow comenta sobre o tema, em artigo publicado sobre a exposição Fotografias Artísticas: "(...) encarando-se o quadro pelo seu desenho e não como a representação de um ou vários objetos, compreende-se a necessidade de proceder à escolha acertada e ao arranjo do motivo, não bastando tomar um fragmento da natureza e transferi-lo para a fotografia". (Ver BANDEIRA DE MELLO. Arte e Fotografia: o movimento pictorialista no Brasil. Rio de Janeiro: Funarte, 1998 e POLACOW, Jacob. Pictorialismo em Arte Fotográfica In: Boletim Foto-Cine Clube Bandeirante, ano II n 16, agosto de 1947).

${ }_{234}$ Aqui repete-se a informação da nota de número 2, da introdução, para lembrar que o Foto Cine Clube Bandeirante foi fundado com o nome de Foto Clube Bandeirante. Somente em 1945 passaria a adotar o nome de Foto Cine Clube Bandeirante, a partir da criação do departamento de Cinema.

${ }^{235}$ COSTA, Helouise \& SILVA, Renato Rodrigues, op. cit. p. 13. Os autores irão apontar mais adiante no capítulo 2 (A fotografia Moderna no Brasil) que "embora haja notícias de especulações modernas esparsas fora do ambiente fotoclubista, a documentação até agora levantada aponta que essa prática só se realizou sistematicamente e como experiência de grupo no Foto Cine Clube Bandeirante", referindo-se a experiências como as de Jorge de Lima, Athos Bulcão e Fernando Lemos, como esclarecem ao citar bibliografias sobre o assunto em nota de rodapé. (ver págs. 36 e 120). 
Os pioneiros do Foto Cine Clube Bandeirante atuaram no espaço aberto pelo abandono dos processos pictoriais. Negar a hegemonia da técnica permitiu ao fotógrafo uma reaproximação da natureza e com isso o experimentalismo foi deslocado da questão puramente técnica para a construção de uma nova sensibilidade. Desenvolveu-se uma visão moderna através da retomada do empirismo na prática fotográfica $^{236}$.

Se, em linhas gerais, o trabalho de Thomas Farkas, no Bandeirante, caracterizava-se pela busca de ângulos inusitados em composições geométricas e ritmadas e o de Geraldo de Barros por intervenções no processo fotográfico $^{237}$, o trabalho de German Lorca destacava-se, especialmente, pelas cenas cotidianas que apresentava, embora sua produção no local tenha sido absolutamente variada.

A realização de cenas cotidianas por Lorca, no âmbito do Bandeirante, mostra a questão do flagrante como uma possibilidade da fotografia moderna que se voltava à temática urbana e o pioneirismo da atuação do fotógrafo nessa seara. Segundo depoimento do fotógrafo, a respeito de sua produção em comparação a de outros bandeirantes: "no Fotoclube eles faziam mais paisagens, eu fazia mais elemento humano... ${ }^{238 "}$

Em um mesmo Boletim do ano de $1951^{239}$, dois artigos comentam sobre a realização de flagrantes. Sob o título de Elementos Básicos para uma Moderna Estética Fotográfica, o primeiro trazia a seguinte consideração:

\footnotetext{
${ }^{236}$ Idem. ibidem, pgs. 39 e 40.

${ }^{237}$ Idem. ibidem. p 43.

${ }^{238}$ Depoimento concedido à autora em 15 de abril de 2004.

${ }^{239}$ Ver Foto-Cine Boletim, $\mathrm{n}^{\circ} .60$, abril de 1951.
} 
(...) Ao realismo da fotografia se adiciona a possibilidade de o fotógrafo poder reproduzir fielmente, a característica de uma ação. Existem artistas dotados de grande espírito de observação porém sem controle absoluto sobre o mesmo. $O$ fotógrafo possue êsse controle absoluto, no negativo. Êle pode gravar uma ação em fração de segundo e examinar no negativo todas as suas características e se o flagrante foi apanhado no momento exato. Sabemos que o fotógrafo de gênero e de reportagem deve ter a visão bastante treinada para as ações e movimentos. Enfim, a fotografia é a mais indicada para reproduzir o dinamismo da vida (...)

(...) Resumindo, podemos dizer que uma obra de arte fotográfica deve apresentar dois elementos principais:

1-) a utilização básica da luz como elemento básico da composição;

2-) a reprodução da dinâmica da vida $(. . .)^{240}$

Ou seja, nesse artigo subtende-se que um dos componentes da estética moderna da fotografia seria o flagrante que reproduz a "dinâmica da vida".

Por outro lado, o segundo artigo, que comenta um concurso interno intitulado "Cenas de Gênero", constata que era reduzida a produção de flagrantes pelos fotógrafos do Bandeirante:

Quando se processaram as inscrições e, posteriormente o julgamento, tivemos ensejo de observar como foi o tema resolvido pelos inscritos. Alguns preferiram colher flagrantes de crianças; outros, lançaram mão de cenas esportivas; também tivemos o registro de cenas de rua, porém em menor escala e em nível de expressão bem mais modesto. No entanto, quem como nós vive numa cidade como S. Paulo onde em cada instante um olho experimentado "descobre" quadros notáveis, não poderia deixar de

\footnotetext{
${ }^{240} \mathrm{O}$ trecho reproduzido segue a grafia da época. Ver AVRAMESEU, Georges. Elementos Básicos para uma Moderna Estética Fotográfica In: Foto-Cine Boletim n. 60 de 1951.p.7. O artigo contém um box informando sobre a importância de seu autor: "Com este (sic) artigo inicia sua colaboração em nosso Boletim, o conhecido e renomado artista-fotógrafo Georges Avrameseu, de Arad, Rumania. Autor laureado em inúmeros certames, é um nome que dispensa apresentação e cujos títulos internacionais são o justo reflexo de seus conhecimentos técnicos e qualidades artísticas. Estão, pois, de parabéns os leitores de FOTO-CINE, que não poupa esforços a fim de mantê-los a par do movimento artístico fotográfico, em todo o mundo, atravéz (sic) da palavra de seus expoentes".
} 
sentir um certo desapontamento, pela reduzida soma de fotografias colhidas nessa imensa metrópole, em seus ambientes típicos ou de suas figuras também peculiares $^{241}$.

Dentro desse contexto tímido, traçado por Antonio Victor, a fotografia de rua de Lorca devia chamar a atenção, uma vez que era uma das poucas a acompanhar o interesse de certos gravadores, pintores e desenhistas do período: o interesse na tematização da cidade com seus "contrastes característicos $^{242 " .}$

Essa conexão estabelecida por Antonio Victor entre fotografia de rua e flagrante talvez possa ajudar a entender a razão para o fato de Lorca ter encenado algumas de suas fotos, fazendo-as passar por flagrantes.

Lorca, atuando então como amador, podia se valer da pose porque os objetos de suas fotos - como a de outros amadores - eram, na maioria, seus parentes $^{243}$. Usando a sobrinha, ou outro parente, ele podia pedir que seu modelo repetisse a cena quantas vezes fosse preciso. E assim procedendo ele se enquadrava nos cânones do flagrante, tão valorizado por certos segmentos do Bandeirante.

Dentro da cultura visual do período no Brasil havia um outro produtor de imagem que também se valia do pseudoflagrante e que pode ter ajudado a ampliar o repertório do então jovem fotógrafo German Lorca: o francês Jean Manzon que, entre os anos de 1943 e 1951, no Brasil, encenou muitas fotos de

\footnotetext{
${ }^{241}$ Ver VICTOR, Antonio S. O Fotógrafo e as cenas de Gênero. In: Foto-Cine Boletim, nº 60, abril de 1951. p. 8.

242 Ver catálogo da exposição Cinqüenta50, op. cit.Nesse contexto o curador da mostra cita as gravuras de Carlos Prado, as fotos de German Lorca, um quadro de Mário Zanini e o desenho de Odila Mestriner pertencentes ao Acervo do MAM e que estiveram presentes na exposição. Das 50 fotografias de Lorca que integram essa coleção, todas voltadas à temática urbana paulista, 19 foram realizadas entre 1949 e 1956.

${ }^{243}$ Lembremos, por exemplo, de nomes como Jacques Henri-Lartigue, que teve grande atividade como fotógrafo amador. Dentro do trabalho de Lartigue, chama-se a atenção para as fotografias que ele realizou de sua esposa, Bibi, a partir de 1919, quando passa a registra-la em situações que parecem espontâneas.
} 
modo a se aproximar da estética do flagrante em seus trabalhos para a revista ilustrada O Cruzeiro ${ }^{244}$.

Manzon chega ao Brasil no final dos anos 1930, fugindo do nazismo. Nesse período estava em vigência no país o Estado Novo, de maneira que Manzon vai trabalhar primeiro no DIP - o Departamento de Imprensa e Propaganda, do governo Getúlio Vargas -, com uma carta de recomendação de Alberto Cavalcanti, e depois na revista O Cruzeiro.

O fotógrafo traz na bagagem sua experiência como fotojornalista de importantes revistas francesas como a $V u$ e a Paris Match, entre outras, acumulada durante alguns anos da década de 1930:

Para a $V u$ Jean Manzon iria fazer prioritariamente reportagens sobre assuntos políticos. Reuniões, cerimônias, enterros de personalidades eminentes, a vida familiar de ministros, para citar alguns dos temas que às vezes rendiam a fotografia de capa. Vemos nessas imagens o emprego de inúmeros recursos de linguagem: flagrantes, retratos posados, fotos de caráter formal, uso de legendas internas ${ }^{245}$.

Jean Manzon passa a empregar o falseamento de flagrantes, por volta de 1936, durante a sua atuação na Paris-Match, revista do grupo Provoust, como uma linguagem fotojornalística capaz de transmitir a idéia de fato sensacional. Tal idéia surgiu no âmbito da própria revista que, ao que parece, pregava a preparação das imagens que seriam colhidas.

Helouise Costa aponta que:

\footnotetext{
${ }^{244}$ A Revista O Cruzeiro surgiu em 6 de dezembro de 1928 a partir de um projeto de Carlos Malheiros Dias de lançar uma revista de circulação nacional. "Malheiros já havia feito alguns investimentos nesse sentido, inclusive registrado o nome do novo empreendimento - Empresa Gráfica Cruzeiro S.A. -, mas não tinha recursos para ir adiante. O projeto viabilizaria-se através de Assis Chautebriand(...)Como não dispunha de verba necessária, Chateubriand recorreu a um de seus contatos políticos: o então Ministro da Fazenda Getúlio Vargas(...)Assim nasce a nova revista, vinculada aos interesses de Getúlio Vargas, que prevê as possíveis vantagens de seu futuro uso político". Ver COSTA, Helouise. Um olho que pensa - estética moderna e fotojornalismo. Tese de Doutrado, FAU-USP, 1998, p. 111.

245 Idem, ibidem. p. 130.
} 
De fato, o tipo de trabalho realizado pelos fotógrafos da Match envolvia a "preparação" das fotografias em busca do "sensacional, do pitoresco, do insólito, do inverossímel", como afirma o fotógrafo ${ }^{246}$.

Nesse contexto, Costa destaca uma afirmação de Jean Manzon segundo a qual o fotógrafo conta que na Paris-Match ele sai do ritmo desenfreado do cotidiano de modo que pode preparar suas fotos e executá-las cuidadosamente ${ }^{247}$.

Manzon privilegiava a captação das imagens com base em preceitos da fotografia européia como o enquadramento a partir de ângulos de baixo para cima, ou o inverso, a realização de tomadas oblíquas e a ênfase em detalhes expressivos, conclui-se, para transmitir o sensacionalismo, ou dramaticidade, do fato. O cinema de vanguarda também estava entre as referências de trabalho do fotógrafo, que se pautava no seu conceito de montagem.

Ainda, Manzon fazia uso de cenário e a própria câmera que utilizava uma Rolleiflex -, era igualmente propícia para registrar os fatos encenados: ela possibilita tanto o controle da composição como a marcação prévia do espaço.

Para adaptar o estilo da Match em O Cruzeiro, Manzon solicita a contratação de David Nasser, repórter do jornal O Globo, o qual ele conheceu durante sua viagem pela Amazônia ${ }^{248}$ :

Jean Manzon e David Nasser iriam formar uma dupla de repórteres perfeitamente afinada, que se tornaria bastante conhecida devido a sua atuação em O Cruzeiro. Ao

\footnotetext{
${ }^{246}$ Idem, ibidem. p. 133.

247 Idem, ibidem.

${ }^{248}$ Para adotar a fórmula da revista Paris Match era necessário encontrar um repórter que se adaptasse ao estilo de texto adequado à fotoreportagem. Ver COSTA, Helouise, op. cit., p. 137.
} 
longo de oito, dos vinte e dois capítulos de sua biografia, Jean Manzon se ocupou de relatar episódios pitorescos da realização de várias das reportagens que produziu para a revista brasileira até a sua saída(... $)^{249}$

Como a concepção geral da revista Paris-Match era pautada nos princípios da Life uma - "revista de reportagem, abrangendo assuntos variados para um público amplo, cujo principal atrativo residia na fotorreportagem ${ }^{250 " ~-, ~}$ Manzon empregaria em O Cruzeiro a fórmula narrativa que foi sistematizada pela revista norte-americana, baseada no conceito de "estória ${ }^{251 " . ~}$

A "estória" consiste no planejamento da fotorreportagem a partir do roteiro de fotos preparado pelos editores para o fotógrafo, o qual deve requisitar diferentes tipos de imagens: as fotos principais (que estabelecem a estrutura da narrativa), as de transição (que guiam o leitor de uma idéia a outra), as de ação (que transmitem o drama) e, finalmente, as fotos que indiquem a conclusão da estória ${ }^{252}$.

A contribuição de Manzon para a revista O Cruzeiro foi seminal para a introdução de um novo e moderno conceito de fotorreportagem ${ }^{253}$, pautada no sensacionalismo e na encenação como busca da imagem que simbolize um ideal. Além disso, a atuação do fotógrafo foi importante para a conformação de uma cultura de massa no Brasil ao mesmo tempo em que crescia o papel da publicidade como fonte de sustentação dos periódicos, segundo os dados de Costa.

\footnotetext{
${ }^{249}$ Idem, ibidem.

250 Idem, ibidem, p. 159.

251 Uma das primeiras reportagens em que Jean Manzon aplica a fórmula narrativa da Life com sucesso em $O$ Cruzeiro, segundo Costa, é na matéria Os presos falam de liberdade, publicada na edição de 11 de março de 1944 da revista. Ver COSTA, Helouise. Op. cit. p. 160 e 161. A estudiosa comenta a estrutura narrativa da reportagem, ilustrada em cinco fotografias, que obedece aos critérios de fotos principais, de transição, de ação e as de conclusão.

252 Idem, ibidem. p. 159.

${ }^{253} \mathrm{~A}$ esse respeito Rubens Fernades Júnior considera que "A revista semanal O Cruzeiro foi a mais importante contribuição para o fotojornalismo brasileiro e para a construção de um país moderno e sintonizado com a informação internacional e os avanços tecnológicos". Ver FERNANDES JÚNIOR. Rubens. Labirintos e identidades: Panorama da fotografia no Brasil [1949-98]. CosacNaify/Centro Universitário Maria Antônia: 2003 (1ª edição).
} 
Os recursos de linguagem empregados por Manzon, como a questão da encenação, servirá de base para revistas voltadas à propaganda política no Brasil como a Riquezas de Nossa Terra, a S. Paulo e Em Guarda S. Paulo, com atuação durante os anos $1940^{254}$.

${ }^{254}$ Ver item 3 do capítulo 2 da tese de Helouise Costa (op. cit.), intitulado "Fotografia e Propaganda Política no Brasil", págs. 165 a 169. 
Jean Manzon (O Cruzeiro), Henri Cartier-Bresson (Life) e German Lorca (Foto-

Cine Clube Bandeirante): a formação de um repertório visual.

Embora a historiadora Helouise Costa tenha considerado não ser possível um paralelo entre uma produção fotojornalística e uma amadora, na época em que German Lorca pertencia ao Bandeirante ${ }^{255}$, acredito que seria importante pensar nessa possibilidade, no caso que envolve Manzon e Lorca. E tal possibilidade torna-se efetiva pelo caráter público da fotografia jornalística, no sentido de sua circulação massiva, a partir do entre-guerras, que faz com que qualquer cidadão possa ter acesso ao conteúdo fotográfico de uma revista ou jornal ilustrado 256 .

Para se pensar os padrões estéticos das fotorreportagens de Jean Manzon na revista O Cruzeiro como algo já instituído na época em que German Lorca ingressou no Bandeirante - e que, portanto, fazia parte da cultura visual fotográfica dos anos 1940 - serão tomadas como exemplo algumas fotografias de Manzon contidas nas seguintes matérias realizadas no ano de $1944^{257} \mathrm{e}$ publicadas em O Cruzeiro: Os presos falam de liberdade ${ }^{258}$ [llustração 2.4] e $A$ tragédia dos abandonados ${ }^{259}$ [llustração 2.5], em comparação às fotografias

\footnotetext{
${ }^{255}$ Helouise Costa, na palestra "O estético e o social na trama fotográfica", pois eram universos separados e que portanto, em tese, não se influenciavam um pelo outro. Sobre a palestra ver nota de $n^{\circ} 34$ da introdução desse estudo. ${ }^{256}$ Sobre o conceito de fotografia pública ver FERNÁNDEZ, Horácio (ed). Fotografía Pública. In: Fotografia Pública Photography in Print 1919-1939. Museu Nacional Centro de Arte Reina Sofia. Madrid: Aldeasa, 2000.

${ }^{257}$ As referidas matérias são da dupla David Nasser (texto) e Jean Manzon (foto). Este estudo utiliza-se de fotografias de Jean Manzon, na Revista O Cruzeiro do ano de 1944 ao invés do anos de 1948 a 1951, quando Lorca já pertencia ao Bandeirante para refletir sobre os valores modernos embutidos nas fotografias de Manzon que já estavam instituídos quatro anos antes de German Lorca ingressar no Foto-Cine Clube Bandeirante.

${ }^{258}$ Ver Revista O Cruzeiro, edição de 11 de março de 1944. Esta matéria foi citada anteriormente na nota de $n^{\circ} .63$ do presente capítulo.

${ }^{259}$ Ver Revista O Cruzeiro, edição de 18 de março de 1944.
} 
Homem na Chuva (1950) [Ilustração 2.4] e Cortiço no Brás (1949) [llustração

2.5], de German Lorca, que apresentam grande proximidade estética.
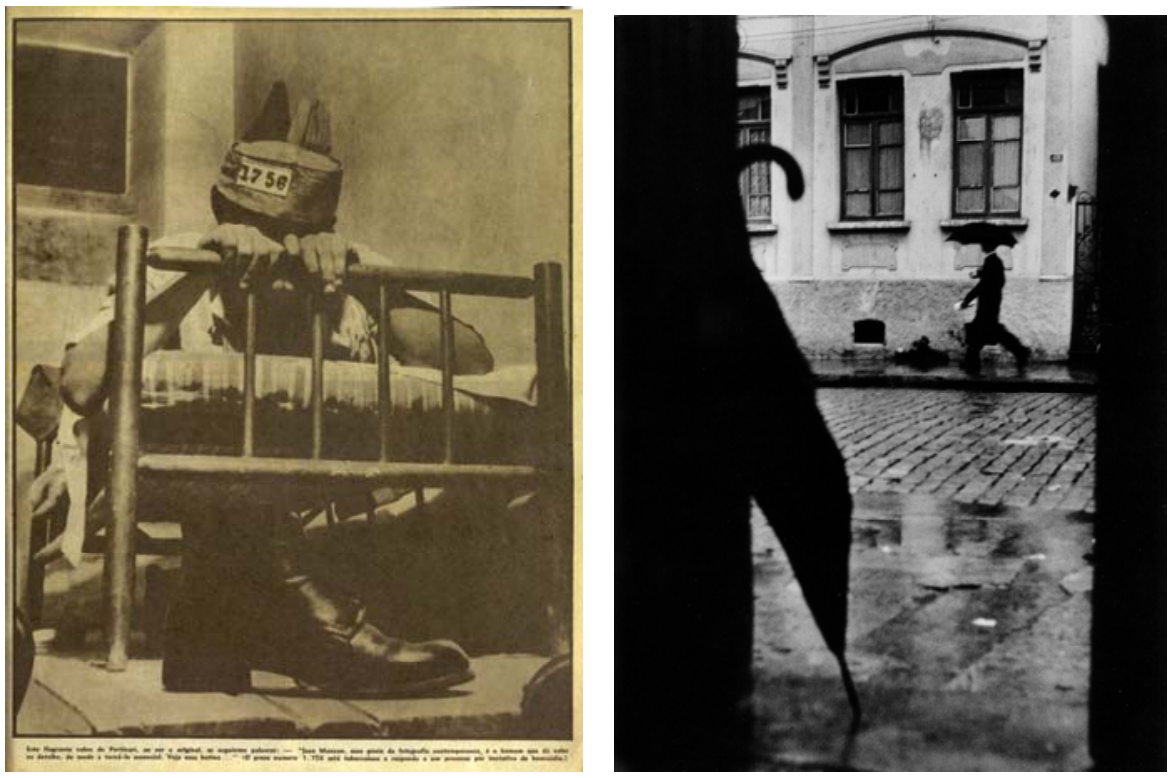

Ilustração 2.4: Fotografia final da fotorreportagem Os presos falam de liberdade, Jean Manzon, Revista O Cruzeiro, 11 de março de 1944 (à esquerda). Acervo da Biblioteca e Centro de Documentação do Museu de Arte de São Paulo Assis Chateaubriand. Homem na Chuva, German Lorca, 1950 (à direita). Coleção Museu de Arte Moderna de São Paulo.

A fotografia do preso de número "1756", a quarta e última da fotorreportagem citada, foi totalmente encenada, segundo dados de Costa: "O presidiário esconde o rosto por detrás das grades de sua própria cama, que reproduzem, na esfera íntima, o seu aprisionamento interior: a legenda nos informa que ele está tuberculoso $(\ldots)^{260 "}$

Apesar da encenação, essa mesma legenda refere-se à fotografia como "este flagrante 261 ", ao mencionar um comentário de Cândido Portinari:

\footnotetext{
${ }^{260}$ Ver Costa, Helouise. op. cit. p. 161.

${ }^{261}$ Aqui cabe refletir sobre a dimensão do emprego da palavra "flagrante". Portinari pode ter se referido de fato a fotografia como um flagrante de um preso em sua cela. Porém este estudo não pode deixar de apontar a possibilidade de o termo flagrante abarcar um sentido metafórico. O que Jean Manzon flagra, na fotografia do preso de número 1756, não é a cena de um cárcere. Pelo contrário. Uma vez que a informação da tuberculose do preso nos é dada na legenda, o que o fotógrafo flagra é o sentimento de impotência do encarcerado frente a iminência de sua morte em decorrência da doença.
} 
Este flagrante, valeu de Portinari, ao ver seu original, as seguintes palavras: - "Jean Manzon, esse gênio da fotografia contemporânea, é o homem que dá valor ao detalhe, de modo a torná-lo essencial. Veja essa botina..." (O preso número 1756 está tuberculoso e responde a um processo por tentativa de homicídio ${ }^{262}$.

A fotografia Homem na Chuva (1950), de German Lorca, também foi encenada segundo depoimento que o fotógrafo concedeu à autora ${ }^{263}$, como será visto no capítulo 3.

Em ambas as fotografias existe um detalhe que constitui um elemento simbólico evidente: a botina, em Jean Manzon, e o guarda-chuva, em German Lorca.

A botina, conforme observa Portinari, será um elemento essencial na fotografia de Manzon. A botina está ali como mais um símbolo (o outro será as grades da cama, lembre-se) da condição de apatia e impotência do preso frente a tuberculose que o matará. Talvez por isso, nessa encenação, um pé de seu sapato tenha sido cuidadosamente posicionado em frente à cama e o outro em baixo dela sugerindo desorganização e desânimo. Se o preso irá morrer de tuberculose para que ter o par de sapatos aos pés da cama para vesti-lo se for absolvido do crime?

Já o guarda-chuva, na fotografia de German Lorca, está também, cuidadosamente posicionado: apoiado no batente da porta, o guarda-chuva simboliza a chuva. Esse detalhe parece que ali está para anunciar o assunto da fotografia.

O guarda-chuva, além de abrir o campo de interpretação da imagem propiciando-Ihe uma narrativa - um homem, sob um guarda-chuva, anda na

${ }^{262}$ Ver Revista O Cruzeiro, edição de 11 de março de 1944.

${ }^{263}$ Depoimento concedido à autora em 15 de abril de 2004. 
rua em um dia chuvoso enquanto em uma casa, na calçada oposta, um guarda-chuva está encostado no batente da porta para secar -, cria um jogo composicional na fotografia. Esse jogo resulta em uma estética que confere à fotografia um valor artístico: o guarda-chuva da porta, em primeiro plano, está fechado e forma uma linha paralela com o homem que anda na chuva, com um guarda-chuva aberto. Aqui há um jogo de oposição entre o guarda-chuva fechado e o aberto, entre aquele que aponta para o chão (guarda-chuva da porta) e o que aponta para o alto (o que o homem segura). Além disso, o batente da porta, no qual está apoiado o guarda-chuva, emoldura a imagem do homem caminhando.

A aproximação entre essas fotografias de Jean Manzon e German Lorca evidencia o fato de que o flagrante, na fotografia moderna, constituirá um valor artístico, tanto no fotojornalismo como no fotoamadorismo, independente de haver ou não uma influência direta de um âmbito para o outro.

Tal valor nasce de uma estética compositiva própria do flagrante pautada na capacidade de se registrar a beleza de um instante e no tipo de tomada - como é feito o enquadre da cena -, que irá revelar a plasticidade da imagem. Sob essa perspectiva, a encenação de um fato para a realização de um pseudoflagrante com a intenção de transmitir a idéia de espontaneidade será próxima da estética de um flagrante autêntico, de modo a atingir um mesmo patamar de fotografia artística. 

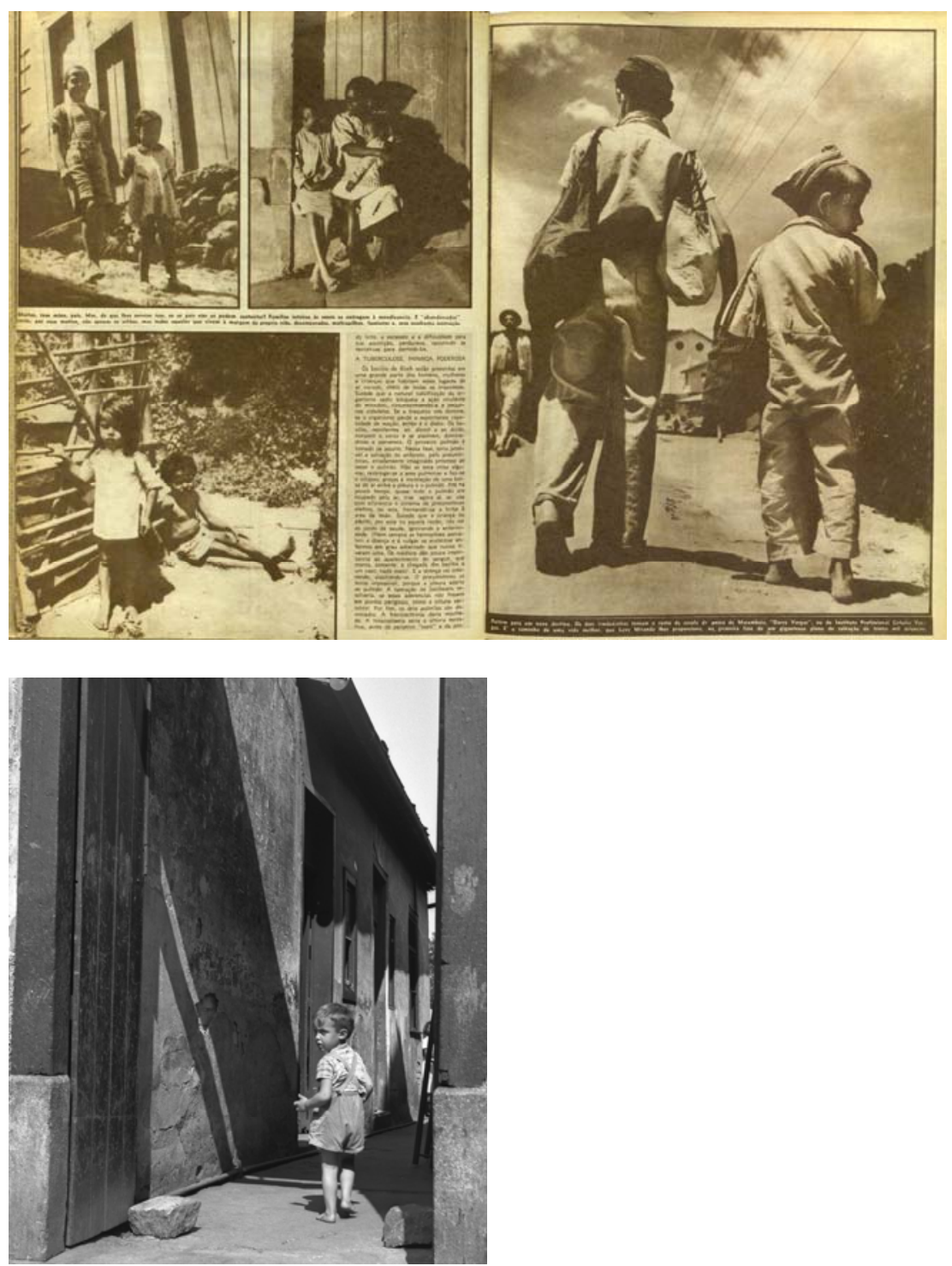

Ilustração 2.5: Terceira e quarta páginas da fotorreportagem $A$ tragédia dos Abandonados, de Jean Manzon, Revista O Cruzeiro, 18 de março de 1944. Acervo da Biblioteca e Centro de Documentação do Museu de Arte de São Paulo Assis Chateaubriand. Cortiço no Brás, German Lorca, 1949 (acima). Coleção Museu de Arte Moderna de São Paulo. 


\section{A matéria A tragédia dos Abandonados tem a seguinte chamada:}

Nem sempre o repórter descobre facilmente, no assunto perseguido, a nota trágica que dará humanidade à história do fato. No tema da reportagem de hoje, a dificuldade estaria em achar, a nota menos trágica, um ponto de luz na tragédia dos abandonados. Trinta mil crianças vivem à mercê da bondade do próximo, a caridade irregular, que apenas contemporiza com a miséria, mas não a evita. O governo, através de vários órgãos ministeriais e de uma fundação, a que recebe um fluxo, a inspiração e a vida de Levy Miranda, empreende uma campanha seríssima, no intuito de dar fim ao grave problema da desgraça infantil. E é no momento que esta luta chega ao auge, que julgamos acertado apresentar aos leitores brasileiros, o drama dos menores sem destino $^{264}$.

Portanto, os temas de Manzon nessa reportagem são a miséria, a doença, a moradia precária. Nas três fotografias da página à esquerda da revista, o autor retrata os protagonistas dessa história, as crianças, sob a seguinte consideração:

Muitos tem mães, pais. Mas de que Ihes serve isso, se os pais não thes pode sustentar? Famílias inteiras às vezes se entregam à mendicância. E "abandonados" serão por este motivo, não apenas os órfãos, mas todos aqueles que vivem à margem da própria vida, desamparados, maltrapilhos, famintos e sem nenhuma instrução ${ }^{265}$.

Note-se que nas três fotografias da página esquerda da revista $O$ Cruzeiro, Jean Manzon retrata cortiços.

\footnotetext{
${ }_{264}^{264}$ Ver revista O Cruzeiro, 18 de março de 1944.

${ }^{265}$ Idem, ibidem.
} 
Uma delas, a segunda imagem no topo à direita da página, é a que mais claramente revela que foi posada: a mãe e os filhos olham para a mesma direção, Manzon enfatiza a sombra do grupo projetada sobre a porta de entrada da casa.

Creio que nesse momento só caberia apontar que o flagrante Cortiço no Brás de German Lorca obedece aos mesmos padrões estéticos da cena arranjada de Manzon: a ênfase na figura do habitante do cortiço e a utilização da sombra como recurso plástico.

Essas aproximações dos universos de Manzon e de Lorca permitem perceber que a encenação para um pseudoflagrante será pautada na intenção do fotógrafo em aproximar-se da estética de um flagrante autêntico e assim atingir um cânone que era respeitado tanto pelos editores das revistas ilustradas, quanto por alguns teóricos do Bandeirante (lembrar do texto de Antonio Victor). O culto ao flagrante será mais importante do que sua verdadeira obtenção, tanto no universo do fotojornalismo quanto no do amadorismo. Ele é um elemento muito importante de um tipo de fotografia que era entendida como "moderna", pautada em uma nova maneira de composição. Sob essa perspectiva, a opção pelo flagrante ou pelo pseudoflagrante será puro exercício de composição. Naquele contexto, a fotografia flagrada e outra pseudoflagrada possuem o mesmo valor, tornando tênue a linha que separa uma da outra.

\section{$\S \S \S \S \S \S$}

Como foi mencionado na Introdução foram localizados alguns exemplares da revista Life na Biblioteca Mário de Andrade, que continham fotografias realizadas por Henri-Cartier Bresson. 
Entre elas, encontrou-se mais evidentemente em Atrás da Estação Saint Lazare, aproximações estéticas possíveis com Menina na Chuva, de German Lorca [llustração 2.6].

Atrás da Estação Saint-Lazare que ganhou valor artístico e transformouse em parâmetro de fotografia de arte justamente por ter incorporado o conceito de momento decisivo ${ }^{266}$, torna-se - consciente ou inconscientemente - um modelo a ser seguido por Lorca. Mesmo que, para alcança-lo, o conceito de momento decisivo tivesse que ser burlado.
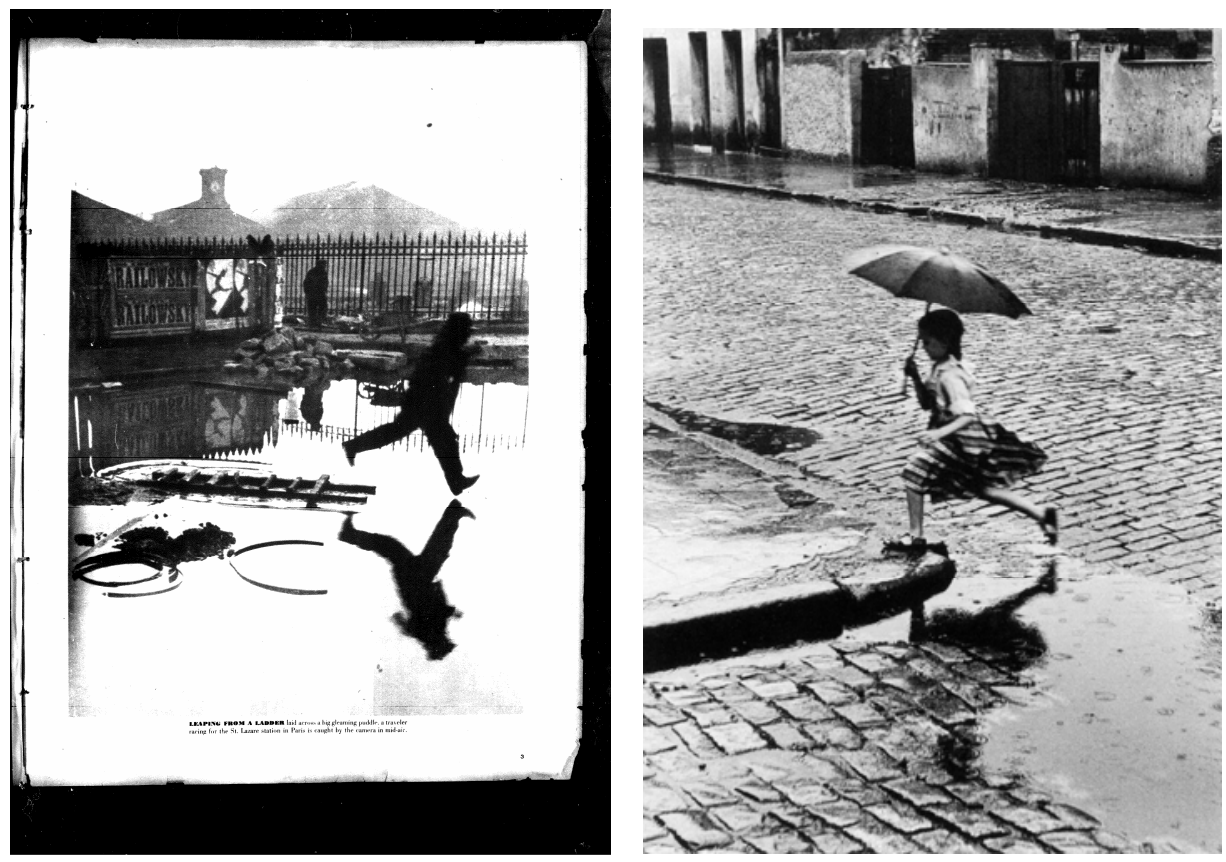

Ilustração 2.6: Atrás da Estação Saint-Lazare, Henri Cartier-Bresson (à esquerda). Imagem publicada na seção Speaking of Pictures da Revista Life (International edition), de 17 de março de 1947. Acervo da Biblioteca Mário de Andrade. Menina na Chuva, German Lorca, 1950 (à direita). Coleção Museu de Arte Moderna de São Paulo.

Por outro lado, outras relações - talvez mais sutis -, podem ser estabelecidas entre o universo de fotografias de Bresson na revista Life e as

${ }^{266}$ Esse assunto será mais propriamente abordado ainda neste capítulo no item "As aproximações possíveis entre Menina na Chuva e Atrás da Estação Saint-Lazare. 
cenas de cotidiano que Lorca realizou enquanto ainda estava no Bandeirante [llustração 2.7, 2.8 e 2.9]:

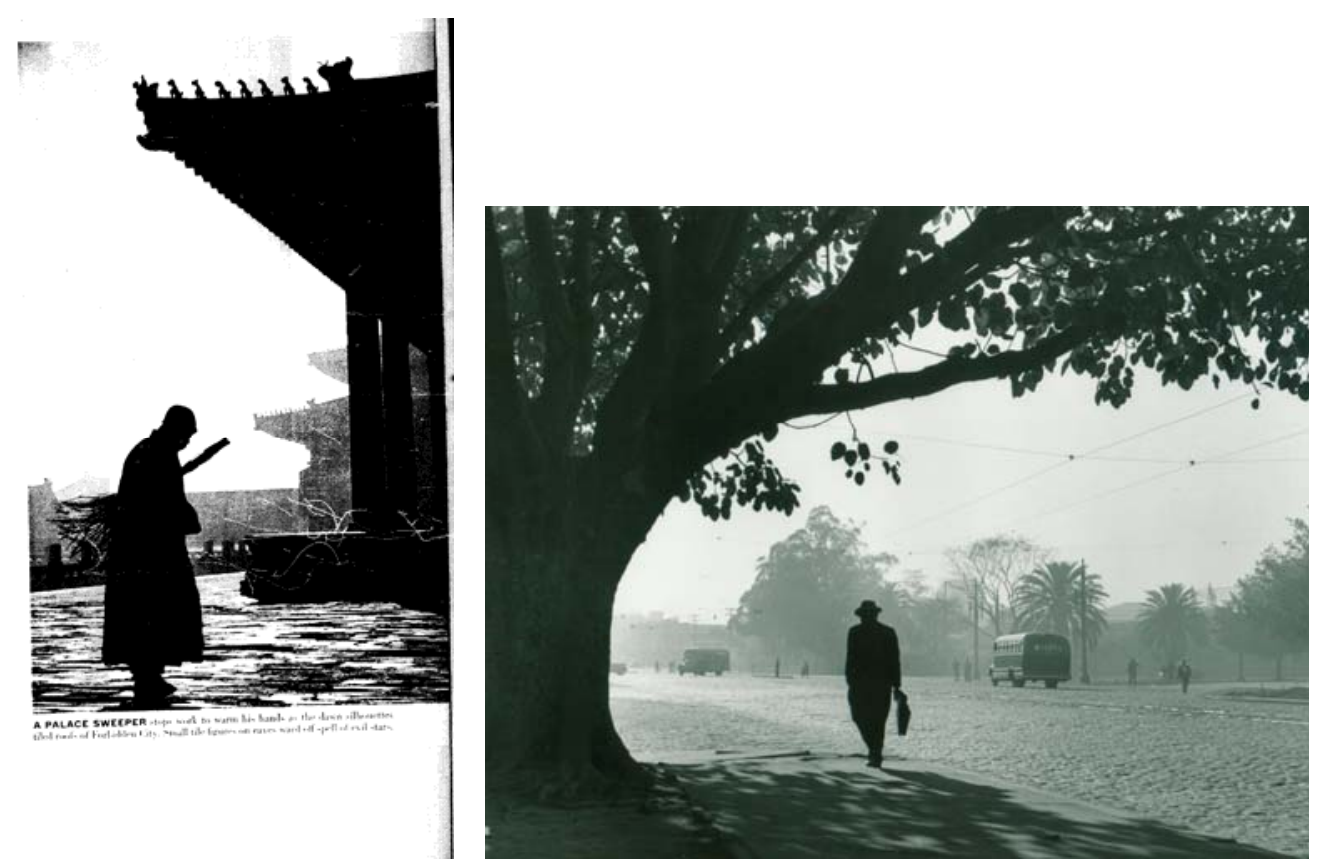

Ilustração 2.7: Detalhe de uma página da matéria A Last Look at Peiping, com fotografia de Henri Cartier-Bresson, publicada na revista Life (International edition), de 31 de janeiro de 1949 (à esquerda). Acervo da Biblioteca Mário de Andrade. Parque Dom Pedro, 1949, German Lorca. Coleção Museu de Arte Moderna de São Paulo.

Note-se que no mesmo ano em que se publica essa fotografia de HenriCartier Bresson, de um "varredor de palácio", como informa a legenda da imagem, German Lorca aplica os parâmetros estéticos nela contidos em Parque D. Pedro. Assim como em "varredor de palácio", a figura humana aparece como silhueta e sua sombra se reflete no chão. 

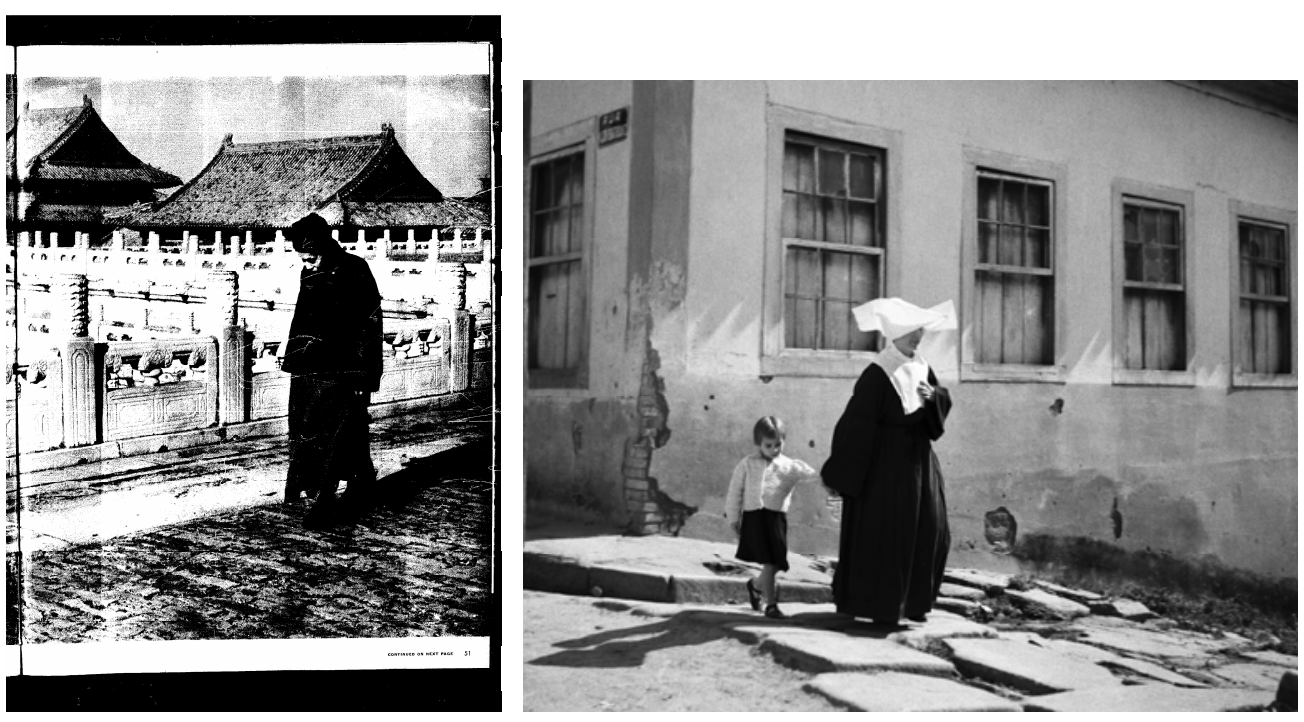

Ilustração 2.8: Fotografia de abertura da matéria A Last Look at Peiping, com fotografia de Henri CartierBresson, publicada na revista Life (International edition), de 31 de janeiro de 1949 (à esquerda). Acervo da Biblioteca Municipal Mário de Andrade. Irmã de Caridade, 1949, German Lorca. (à esquerda). Acervo de German Lorca.

Essas fotografias de Bresson e Lorca também são datadas de 1949. Lorca segue atento ao fator da projeção da sombra da figura humana como elemento estético que confere plasticidade à cena registrada. Além disso, ele parece observar ainda que a cena flagrada apresentada em primeiro plano será um padrão estético da fotografia de arte do tipo flagrante ${ }^{267}$.

\footnotetext{
${ }^{267}$ Irmã de Caridade é um flagrante autêntico e foi realizado em Paraibuna, no ano de 1949, conforme depoimento de German Lorca concedido à autora em 01 de dezembro de 2004. Lorca conta que cortou a fotografia para aproximar a imagem da freira com a criança, uma vez que ele captou a cena à distância. Esse assunto do corte será aprofundado no capítulo 3.
} 

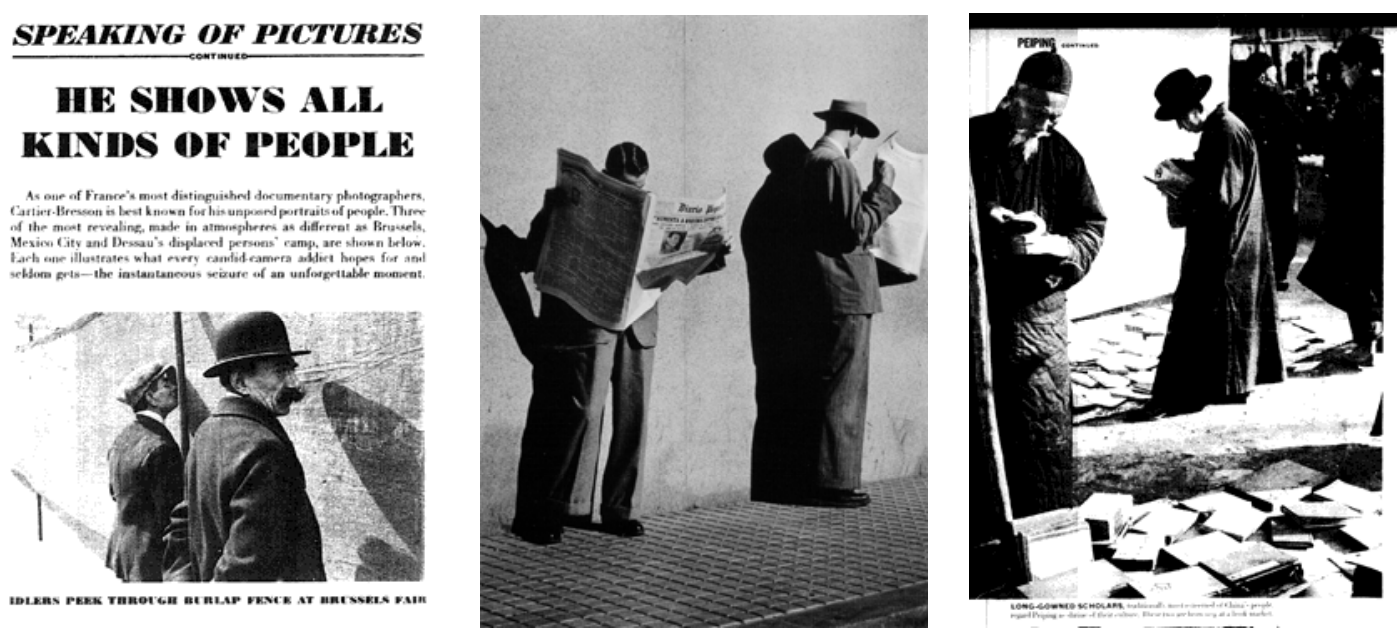

Ilustração 2.9: Última página da seção Speaking of Pictures da Revista Life (International edition), de 17 de março de 1947, com fotografia de Henri Cartier-Bresson (à esquerda). Acervo da Biblioteca Municipal Mário de Andrade. A Procura de Emprego, 1950, German Lorca (ao centro). Coleção Museu de Arte Moderna de São Paulo. Detalhe de uma página da matéria A Last Look at Peiping, com fotografia de Henri Cartier-Bresson, publicada na revista Life (International edition), de 31 de janeiro de 1949 (à direita). Acervo da Biblioteca Mário de Andrade.

Em ambos os flagrantes de Cartier-Bresson mostrados acima, realizados em 1947 e 1949, figuram duplas de pessoas: na fotografia da seção Speaking of Pictures, Cartier-Bresson flagrou o momento em que, segundo informações da legenda, dois homens expiavam uma feira, em Bruxelas, através da fenda na parede ${ }^{268}$. Na fotografia, da matéria The Last Look at Peiping, CartierBresson flagra, em primeiro plano, dois "acadêmicos de batina" (long-gowned scholars), lendo livros disponíveis em um "mercado de livros" (book market) ${ }^{269}$. Aqui, o autor não cortará da fotografia o grupo de pessoas que aparecem ao fundo, como fará Lorca em A Procura de Emprego ${ }^{270}$.

\footnotetext{
${ }^{268}$ O texto que antecede a imagem comenta o seguinte: Tradução Livre: "Um dos mais distintos fotógrafos documentais, Cartier-Bresson é conhecido por seus retratos espontâneos de pessoas. Três de seus mais reveladores retratos, feitos em lugares tão diversos como Bruxelas, Cidade do México e Dessau são mostrados abaixo. Cada um mostra que toda candid camera adiciona esperança por um raramente obtido - instantâneo de um momento inesquecível". A fotografia dos homens olhando através da fenda é a primeira das três a que se refere o texto. ${ }^{269} \mathrm{~A}$ legenda da fotografia informa que a população local considera Peiping como "um lugar que ilumina a cultura".

${ }^{270} \mathrm{Na}$ fotografia original de A Procura de Emprego são mostradas outras pessoas lendo jornal além daquelas que compõem a imagem final, com corte. Cartier-Bresson raramente utilizava-se do recurso do corte, geralmente apresentando a imagem como era captada. Note-se que na imagem em que os acadêmicos lêem, aparecem outras pessoas ao fundo. Lorca, em nome da harmonia da composição, visando alcançar um padrão estético de fotografia de arte, vale-se do corte. Esse assunto será aprofundado no capítulo 3 quando se voltará a debater a fotografia $A$ Procura de Emprego.
} 
Em 1950, quando realizou o flagrante A Procura de Emprego, Lorca revelava dominar as regras de composição fotográfica. $O$ fotógrafo demonstrava ter noção que o tipo de tomada, valorizando determinado aspecto da cena flagrada, constitui um padrão estético.

Note-se que em A Procura de Emprego, o autor apresenta uma composição semelhante à praticada por Cartier-Bresson, atento ao detalhe da projeção da sombra das figuras na parede.

Desse panorama, pode-se concluir que os padrões estéticos do fotojornalismo europeu dos anos 1940 e 1950 que circulavam direta ou indiretamente no Brasil - como foi demonstrado com os exemplos de Jean Manzon (O Cruzeiro) e Henri Cartier-Bresson (Life) -, integrava a cultura visual da fotografia amadora, neste trabalho representada pelas cenas cotidianas de German Lorca realizadas durante a sua atuação no Foto Cine-Clube Bandeirante.

Essa agremiação seria responsável pela difusão de tais parâmetros no âmbito do fotoclubismo paulistano, uma vez que promovia discussões, salões, apoiava exposições e publicava artigos em seus boletins, com conteúdos que davam conta das tendências internacionais da fotografia moderna, surgirdas a partir do fotojornalismo e do fotoamadorismo europeu e norte-americano.

Um fato concreto a esse respeito é que, um ano antes de German Lorca ingressar no Foto-Cine Clube Bandeirante, portanto em 1947, se estabelecia em São Paulo uma possibilidade de diálogo entre a fotografia moderna brasileira e a produção de fotógrafos internacionais.

De acordo com o que se apontou na Introdução, o Bandeirante patrocinou - em conjunto com a União Cultural Brasil-Estados Unidos e com a 
Revista Íris -, uma exposição didática que o Museu de Arte Moderna de Nova Iorque promoveu na Biblioteca Municipal Mário de Andrade com a participação de fotógrafos como Helen Lewit, Ansel Adams, Ralph Steiner, Charles Sheeler, Andreas Feininger, Edward Weston, Henri Cartier-Bresson, Walker Evans, Erich Salomon, Berenice Abott e Paul Strand.

Na seção "fala o editor" da Revista Íris que antecedeu a mostra lê-se:

Será inaugurada no dia $1^{\circ}$ de Julho de 1947 , uma exposição de fotografias norte-americanas, na Biblioteca Municipal de São Paulo (...) Trata-se de um certame digno de todo o interesse daqueles que se dedicam, como amadores ou profissionais, ao "Esporte da Luz".

(...)Ficarão expostas na Biblioteca Municipal de São Paulo, obras mestras dos mais famosos fotógrafos norte-americanos, comentadas e explicadas, sob os ponto de vista técnico e artístico. O fotógrafo brasileiro, estudando o material apresentado e tirando suas conclusões, aproveitando-se da experiência e dos ensinamentos dos mais célebres confrades do Norte, sairá da exposição com a conviç̧ão de ter sido testemunha de expressões artísticas completamente novas e inéditas ${ }^{271}$.

Na mesma seção, do número especial da revista, totalmente dedicado à mostra o editor considera:

Se a fotografia teve seu berço em outra parte, foi contudo na América que efetivamente encontrou o campo mais propício para o seu desenvolvimento. Foi lá, por certo, que atingiu sua maioridade, impondo-se como elemento hoje indispensável à expressão visual de todas as artes e ciências (...) Pelo estudo dos trabalhos desses artistas da objetiva, e de uma longa série de outros

\footnotetext{
${ }^{271}$ Ver Revista Íris Ano I, nº 5, maio de 1947.
} 
fotógrafos de valor, podemos conseguir um valioso aprimoramento de nossa técnica ${ }^{272}$.

Essa edição da revista traz um encarte de doze páginas que reproduz "os quadros expostos na Biblioteca Municipal de São Paulo" sob o título de Fotografia Artística, no qual figura a seguinte introdução:

"Dramática... sem interêsse (sic)... de grande sensibilidade.... verdadeira.... falsa..." tais são os epitetos empregados constantemente em relação a fotografias tomadas com o fechar mecânico do obturador, o que indica que para muitos de nós a fotografia não é sómente (sic) um processo científico de retratar algo, mas sim um Meio de Expressão. A máquina fotográfica é um aparelho de grandes possibilidades, porém, o fotógrafo, como qualquer outro artista, é mais importante que os instrumentos por ele usados. O fotógrafo domina a expressão e o significado da imagem que retrata ${ }^{273}$.

As fotografias do encarte são apresentadas dentro de núcleos que explicam a noção de fotografia artística sob diversos aspectos que se entrelaçam: "O fotógrafo é um artista"; "Trabalha com um aparelho mecânico"; "O seu meio de expressão é uma escala de valores"; "escolhe o seu assunto"; "Compõe com a sua máquina fotográfica"; "Escolhe o momento"; "A máquina fotográfica reproduz detalhes infinitos"; "A máquina fotográfica cria a sua própria perspectiva"; "A máquina fotográfica comprime ou amplia o seu espaço"; "A máquina fotográfica paralisa ou prolonga o movimento"; "A máquina fotográfica traduz as cores em branco e negro”.

Entre os valores abordados na exposição, certamente alguns vão ao encontro direto dos parâmetros que Lorca praticaria em seus flagrantes ou

\footnotetext{
${ }^{272}$ Ver Revista Íris Ano I, nº 6, junho de 1947.
}

${ }^{273}$ Idem, ibidem. 
pseudoflagrantes a partir de seu ingresso no Bandeirante, como é possível observar por meio de fotografias Henri Cartier-Bresson, Erich Salomon e R. Martin contidas no encarte [llustrações 2.10, 2.10.1, 2.10.2], [llustrações 2.11,

\subsection{1], [llustração 2.12]:}

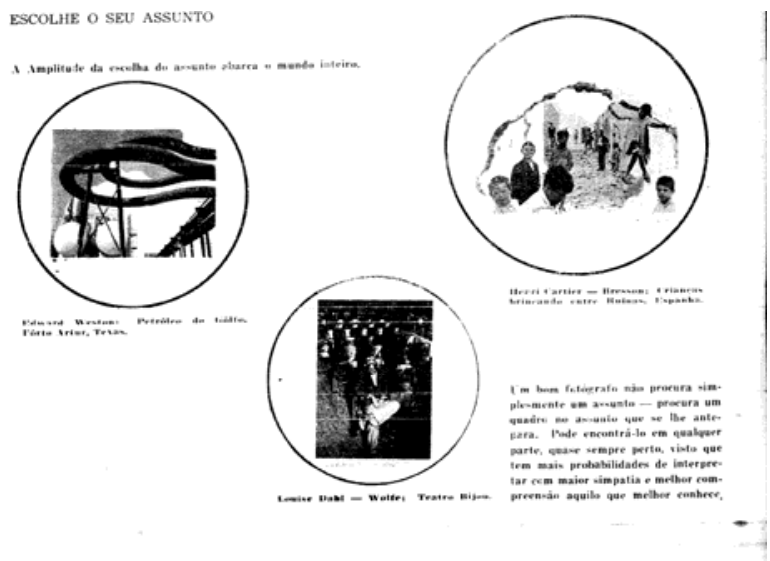

COMPOE COM A SUA MAQUINA FOTOGRAFICA

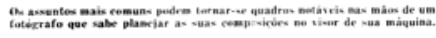

Ilustração 2.10: Página do encarte intitulada "Escolha do Assunto" da exposição organizada pelo Moma/NY na Biblioteca Municipal Mário de Andrade, publicada na Revista Íris, edição de 6 de junho de 1947. Acervo da Biblioteca Municipal Mário de Andrade.

A Amplitute da escolha do assunto abarca
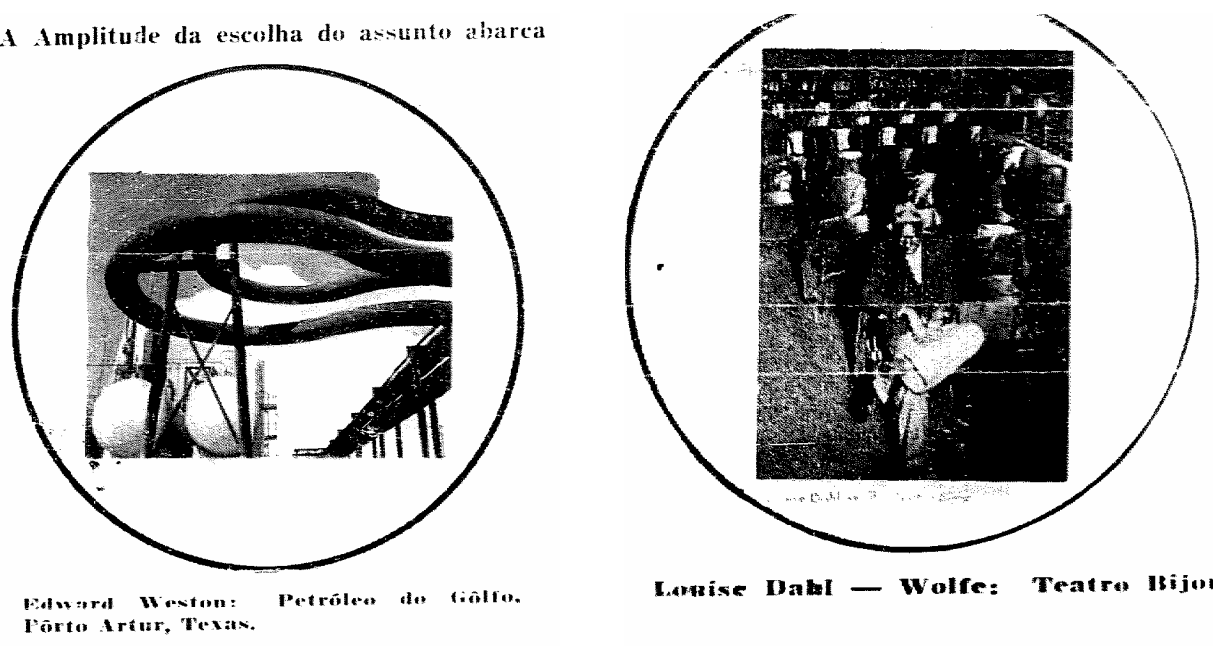

Ilustração 2.10.1: Detalhe da página do encarte reproduzida acima, com fotografias de Edward Weston (Petróleo do Golfo) e Louise Dahl-Wolfe (Teatro Bijou). Acervo da Biblioteca Municipal Mário de Andrade. 


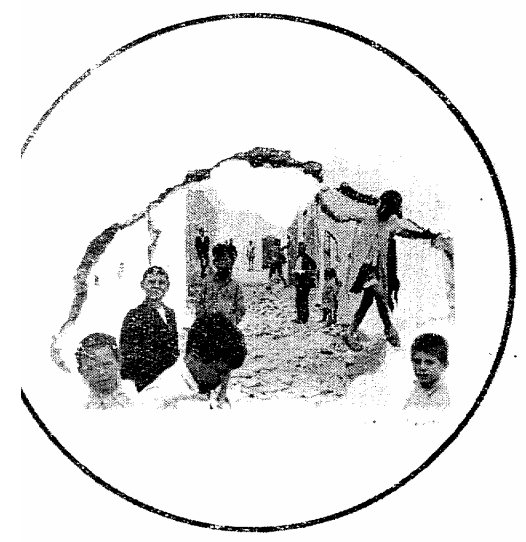

Hetri carrier - Bresson: Criancas

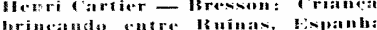

Ilustração 2.10.2: Outro detalhe do encarte com fotografia de Henri Cartier-Bresson (Crianças brincando entre Ruínas, Espanha). Acervo da Biblioteca Municipal Mário de Andrade.

O comentário que figura abaixo da fotografia de Cartier-Bresson, na página sob o tema "Escolhe o assunto", pode tanto se relacionar ao enquadramento de determinada arquitetura (fotografia de Weston) como à idéia de flagrante (Cartier-Bresson e Dahl):

\footnotetext{
Um bom fotógrafo não procura simplesmente um assunto - procura um quadro no assunto que se lhe antepara. Pode encontrá-lo em qualquer parte, quase sempre perto, visto que tem mais possibilidade de interpretar com maior simpatia e melhor compreensão aquilo que melhor conhece ${ }^{274}$.
}

\footnotetext{
${ }^{274}$ Idem, ibidem.
} 


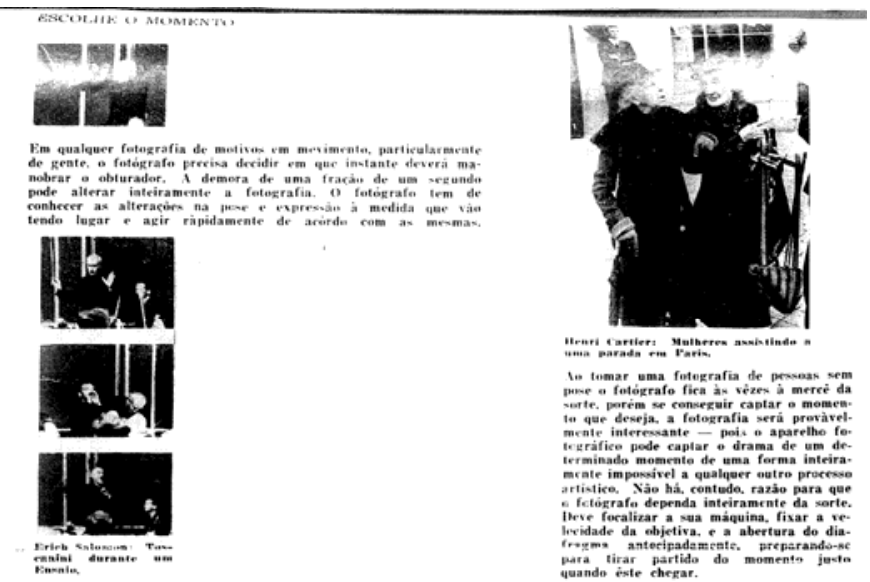

Ilustração 2.11: Página do encarte intitulado "Escolhe o Momento" da exposição organizada pelo Moma/NY na Biblioteca Municipal Mário de Andrade, publicada na Revista Íris, edição de 6 de junho de 1947. Acervo da Biblioteca Municipal Mário de Andrade.

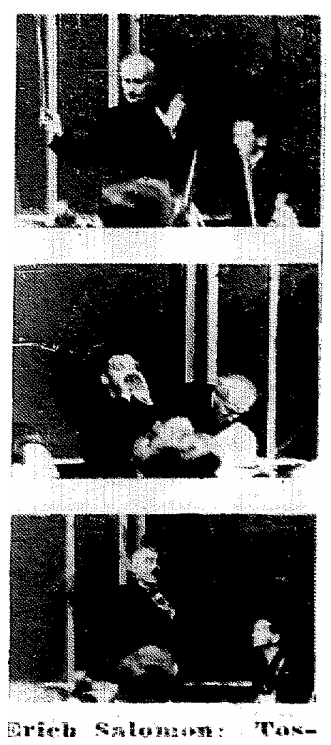

Ilustração 2.11.1: Detalhe do encarte reproduzido na ilustração 2.13.

Seqüência fotográfica realizada por Erich Salomon. Acervo da Biblioteca Municipal Mário de Andrade.

Nessa página do encarte, o tema é a capacidade do fotógrafo em flagrar um fato no momento exato em que ele acontece. Os exemplos utilizados são fotografias de Erich Salomon e Henri Cartier-Bresson.

Acima das fotografias de Salomon, figura o seguinte comentário: 
Em qualquer fotografia de motivos em movimento, particularmente de gente, o fotógrafo precisa decidir em que instante deverá manobrar o obturador. A demora de uma fração de segundo pode alterar inteiramente a fotografia. O fotógrafo tem de conhecer as alterações na pose e expressão à medida que vão tendo lugar e agir rapidamente de acordo com as mesmas ${ }^{275}$.

\section{Abaixo da fotografia de Cartier-Bresson o comentário é o seguinte:}

Ao tomar uma fotografia de pessoas sem pose o fotógrafo fica às vezes à mercê da sorte, porém se conseguir captar o momento que deseja, a fotografia será provavelmente, interessante - pois, o aparelho fotográfico pode captar o drama de um determinado momento de uma forma inteiramente impossível a qualquer outro processo artístico. Não há, contudo, razão para que o fotógrafo dependa inteiramente da sorte. Deve focalizar a sua máquina, fixar a velocidade da objetiva, e a abertura do diafragma antecipadamente, preparando-se para tirar partido do momento justo quando êste(sic) chegar ${ }^{276}$.

Na penúltima página do encarte a questão do flagrante volta a ser apresentada, a partir de observações de como congelar o movimento: "Com uma máquina fotográfica pode-se retratar o movimento que se realiza demasiado depressa ou demasiado devagar para ser percebido pelos nossos $\operatorname{olhos}(\ldots)^{277 "}$

\footnotetext{
${ }^{275}$ Idem, ibidem.

${ }^{277}$ Idem, ibidem.

${ }^{277}$ Idem, ibidem.
} 


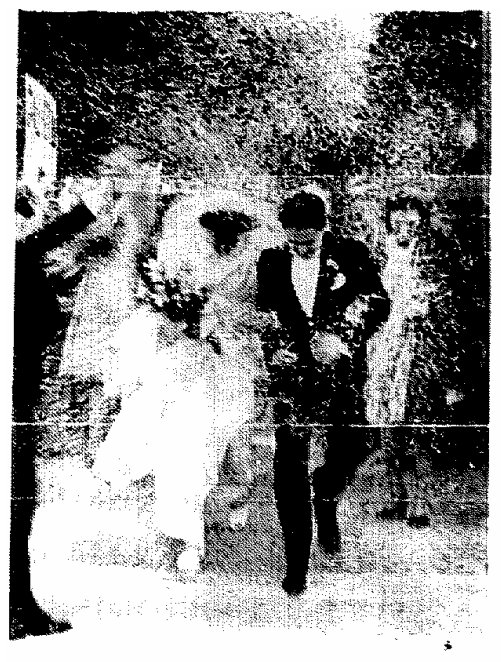

n. Martin: Tempestatle de Arroz.

Ilustração 2.12: Detalhe da página "A máquina fotográfica paralisa ou prolonga o movimento", com fotografia de $R$. Martin. Acervo da Biblioteca Municipal Mário de Andrade.

A respeito da fotografia da ilustração acima, de autoria de R. Martin, lêse ainda no encarte: “(...) a fotografia da cerimônia do casamento recebeu uma exposição de $1 / 28$ de um segundo, o suficiente para captar o movimento do $\operatorname{arroz}(\ldots)^{278}$

Breve reflexão sobre German Lorca e o debate internacional com a fotografia nos anos 1950 no Foto Cine Clube Bandeirante

Tendo como premissa o contexto estabelecido no item acima, o debate internacional no qual Lorca se insere - de maneira consciente ou não -, poderá

\footnotetext{
${ }^{278}$ Idem, ibidem.
} 
ser propriamente observado a partir de sua atuação no Foto-Cine Clube Bandeirante (1948-1952).

Em 1949 o Foto-Cine Clube Bandeirante promove o $8^{\circ}$ Salão Internacional de Arte Fotográfica [llustração 2.13], que totalizou 288 trabalhos admitidos [Ilustração 2.14], no qual Lorca participa com fotografias de natureza diversa como "Circo de Cavalinhos" [llustração 2.15] e "Malandragem" [llustração 2.16], por exemplo.

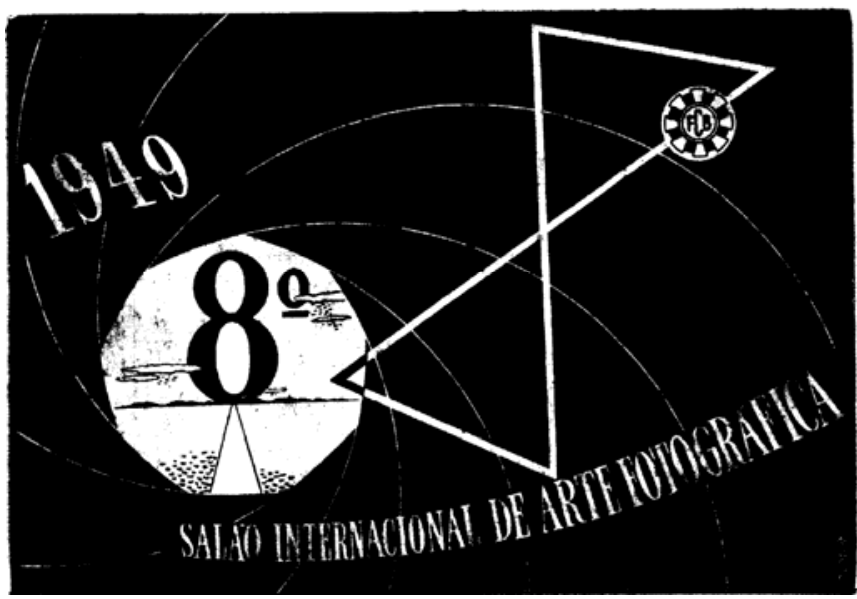

Ilustração 2.13: Capa do catálogo do $8^{\circ}$ Salão Internacional de Arte Fotográfica. Acervo Foto Cine Clube Bandeirante.

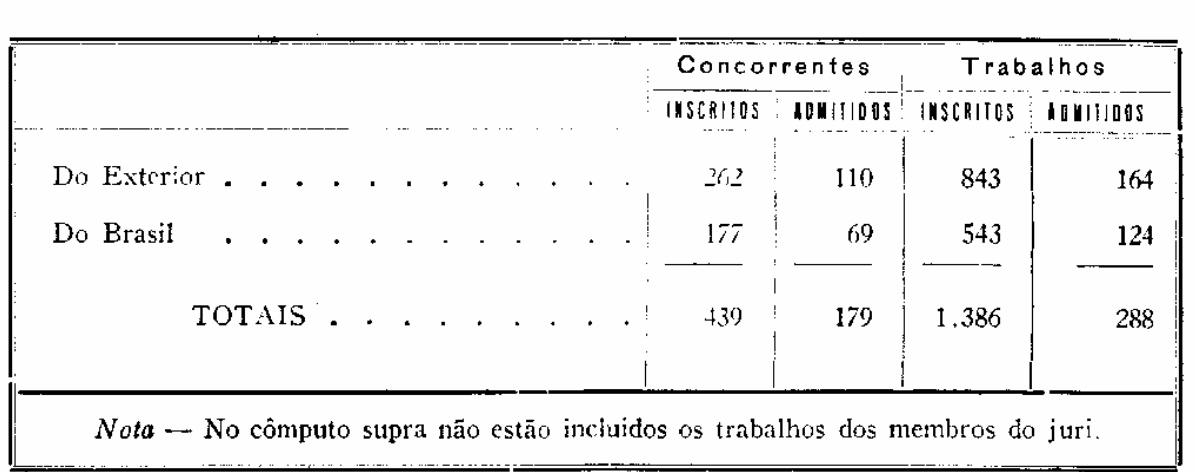

Ilustração 2.14: Tabela com o resumo do número de fotógrafos inscritos e admitidos "do Brasil" e do "exterior", publicada ao final do catálogo. Acervo Foto-Cine Clube Bandeirante. 


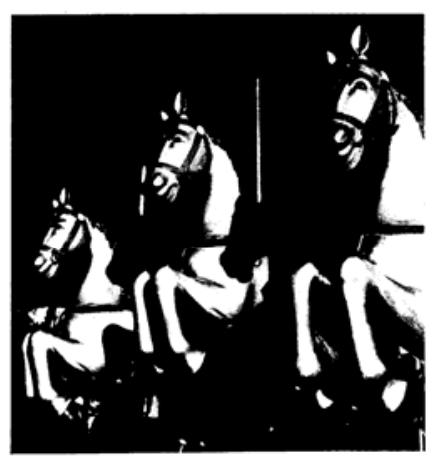

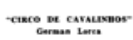

$-13-$

Ilustração 2.15: German Lorca. Circo de Cavalinhos. FCB Boletim, Ano IV, nº. 40, agosto de 1949, seção "As fotografias do Mês". Acervo Foto-Cine Clube Bandeirante/Arquivo Pessoal de German Lorca.

Nesse mesmo salão participaram fotógrafos amadores de destaque de 30 países como a França, representado pelo fotógrafo Henri Lièvre, de Lyon, por exemplo, o que demonstra um debate sobre a atividade amadora de âmbito fotoclubista que extrapola os limites do Brasil ${ }^{279}$.

Segundo dados de um boletim que precedeu o evento, esse salão seria:

(...) uma das mais explendidas mostras de fotografia artística já realizadas no Brasil e em S. Paulo; uma demonstração plena e cabal de que a fotografia é arte e arte das mais difíceis, para qual se exige mais, muito mais do que o simples "apertar do botão", mais do que conhecimentos puramente técnicos; mas acima de tudo, dotes de espírito, temperamento e personalidades verdadeiramente artísticas ${ }^{280}$.

\footnotetext{
${ }^{279}$ No boletim ano IV de número 43, de novembro de 1949 há um artigo intitulado "VIII Salão Internacional de Arte Fotográfica de São Paulo" dedicado a comentar a aproximação da abertura desse salão considerado o "mais importante certame, no gênero, da América do Sul. A lista completa dos participantes desse salão também pode ser vista nesse boletim.

${ }^{280}$ Idem, ibidem.
} 
Nesse trecho, revela-se a preocupação do salão com a questão da fotografia como arte, criticando veladamente a idéia de que para ser um fotógrafo amador, basta "apertar o botão da câmera" - como pregava o slogan da Kodak quando do lançamento de sua câmera portátil em 1888.

Além disso, fica clara qual é a posição do salão a respeito do julgamento do que seria uma fotografia de arte: aquela fotografia realizada por um fotógrafo com "dotes de espírito, temperamento e personalidades verdadeiramente artísticas", mais do que pautada em conhecimentos "puramente técnicos".

Esse "espírito artístico" do fotógrafo, no âmbito do Bandeirante, se formaria por meio de diversos artigos que debatiam questões concernentes a fotografia como arte, tais como o pictorialismo, as discussões em torno da composição e do corte, e dos preceitos da straight photgraphy ${ }^{281}$.

No $8^{\circ}$ Salão Internacional de Arte Fotográfica, essas questões se verificam nas escolhas das obras tanto nas fotografias selecionadas entre os associados do Bandeirante quanto naquelas recebidas de fotógrafos de outros países.

Um paralelo entre a observância dos preceitos da fotografia como arte, de acordo com os padrões do Bandeirante, pode ser estabelecido entre a

\footnotetext{
${ }^{281}$ Entre 1947 e 1951, especialmente, nota-se nos Boletins do Bandeirante uma crescente abordagem desses temas. Ver POLACOW, Jacob. Pictorialismo em Arte Fotográfica. In: Foto-Cine Clube Bandeirante Boletim, Ano II, nºs. 15 e 16, julho a agosto de 1947. BARROS, Valêncio de. A fotografia é arte? In: Foto-Cine Clube Bandeirante Boletim, Ano II, $\mathrm{n}^{\circ}$.16, agosto de 1947. Foto-Cine Clube Bandeirante Boletim, Ano III, $\mathrm{n}^{\circ}$. Março de 1949 O primeiro concurso interno. ESCHEN, Fritz. O Homem por detraz da Câmara. In: FCB Boletim, Ano IV, $n^{\circ}$. 35, agosto de 1949. MEISTER, Frank. A Linha Dominante. In:FCB Boletim, Ano V - n 49, maio de 1950. SOUZA LIMA, Aldo A. Composição In: FCB Boletins ano $\mathrm{V}, \mathrm{n}^{\circ} \mathrm{s} 50$ a 56 , junho a dezembro, de 1950. MASCLET, Daniel. A arte fotográfica de Edward Weston. In: FCB Boletim, Ano $V-n^{\circ} 51$, de julho de 1950. CORREO FOTOGRAFICO SUDAMERICANO.Os Esquecidos. In: Foto-Cine Boletim, Ano V, n.56, dezembro de 1950. NURNBERG, Walter. Arte, Artesanato e Distração. In: Foto-Cine Boletim, Ano V, $n^{\circ}$. 58, fevereiro de 1951.PEASE, D. Ward. Porque introduzir modificações? In:Foto-Cine Boletim, Ano VI, $n^{\circ}$. 61, maio de 1951. AVRAMESEU, Georges. Elementos Básicos para uma Moderna Estética Fotográfica. In:Foto-Cine Boletim, Ano VI, nº. 63, julho de 1951. VICTOR, Antonio da Silva. Corte, Interpretação e Princípios de Composição. In:Foto-Cine Boletim, Ano VI, $\mathrm{n}^{\circ}$. 63, julho de 1951. SALVATORE, Eduardo. Considerações sobre o momento fotográfico. In: Foto-Cine Boletim, Ano VI, nº. 67, Novembro de 1951.
} 
fotografia, Malandragem ${ }^{282}$ [llustração 2.16], de autoria de German Lorca, Ao Cair da Tarde, de Sergio Trevellin [llustração 2.17], ambos do $\mathrm{FCB}^{283}$, e a fotografia Shadow in the Dark [llustração 2.18], do norte-americano Allan L. Hovarth.

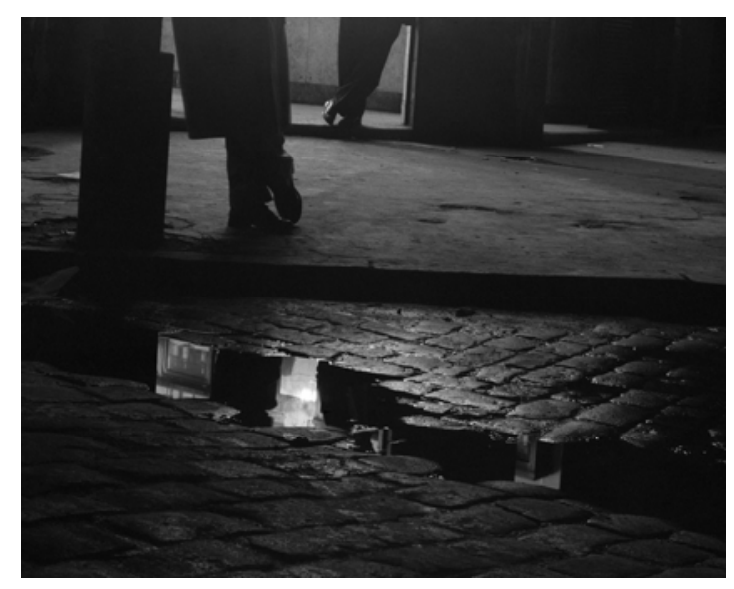

Ilustração 2.16: German Lorca. Malandragem, 1949. Coleção Museu de Arte Moderna de São Paulo

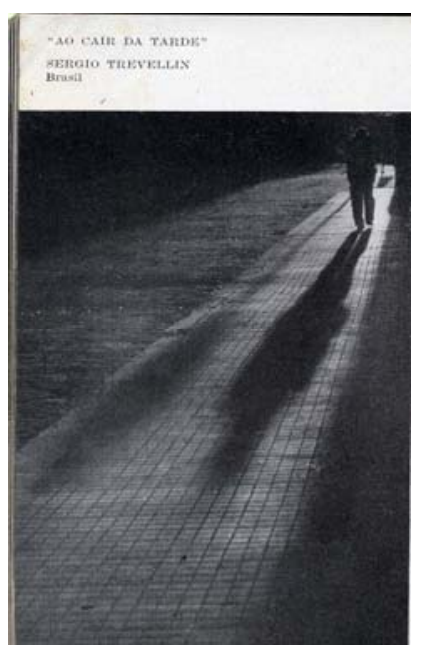

Ilustração 2.17: Sérgio Trevellin. Ao cair da tarde. 1949. Acervo Foto-Cine Clube Bandeirante.

${ }_{283}^{282}$ Essa fotografia será propriamente analisada no capítulo 3 .

${ }^{283}$ Foto-Cine Clube Bandeirante. 


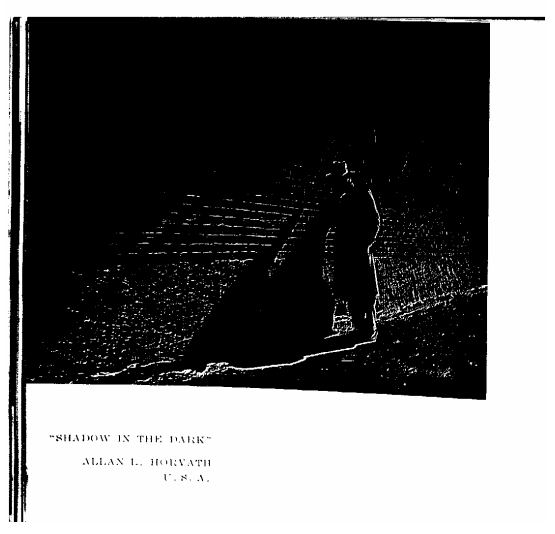

Ilustração 2.18: Allan L. Hovarth. Shadow in the Dark. S.d. Publicada no catálogo do $8^{\circ}$ Salão Internacional de Arte Fotográfica do Foto-Cine Clube Bandeirante. Acervo do Foto-Cine Clube Bandeirante.

Embora a reprodução da fotografia de Hovarth não esteja tão boa é possível perceber que tanto esse fotógrafo como os bandeirantes Lorca e Trevellin trabalham com a questão do espelhamento da imagem. Lorca com o espelhamento pelo reflexo da imagem na água, Trevellin e Hovarth a partir da sombra do homem no chão e na parede, respectivamente.

A idéia de sombra e reflexo, como possibilidade de linguagem da fotografia moderna, remonta a noções como a straight photography [Ilustração 2.19], norte-americana e a Nova Objetividade alemã, que marcaram as estéticas fotográficas do entre guerras ${ }^{284}$. Ao mesmo tempo, a idéia de sombra e reflexo irá ser difundida também através da circulação de fotorreportagens de fotojornalistas europeus - a exemplo de Henri Cartier-Bresson - em revistas como a Life [llustração 2.20].

\footnotetext{
${ }^{284}$ Ver SOUSA, Jorge Pedro. op. cit. p. 67.
} 


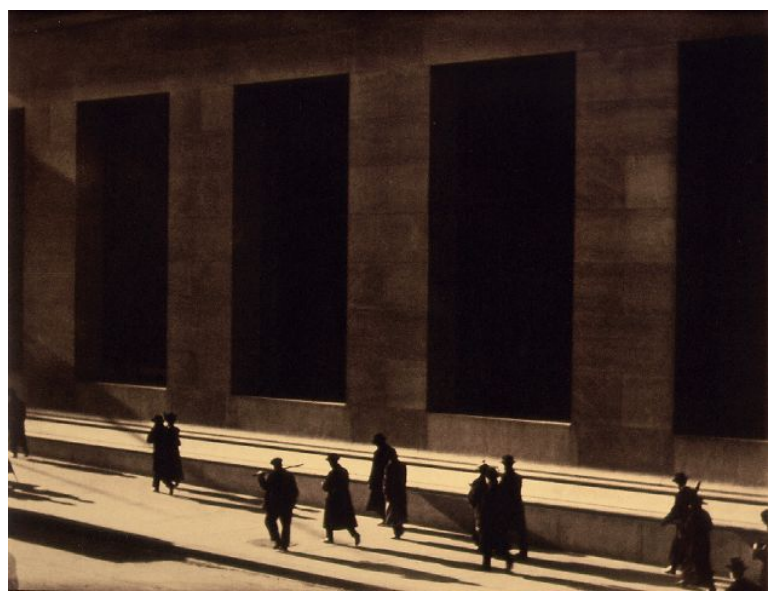

Ilustração 2.19: Paul Strand. Wall Street, 1915.

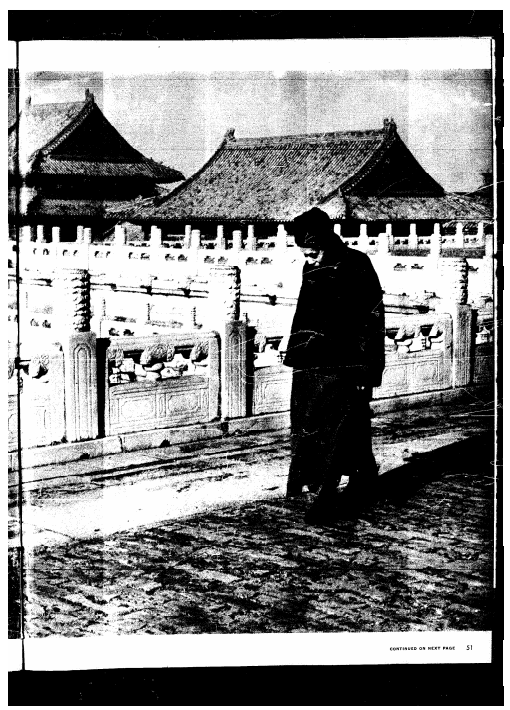

Ilustração 2.20: Detalhe da matéria $A$ Last Look at Peiping. Fotografia de Henri Cartier-Bresson. Revista Life (International edition), de 31 de janeiro de 1949. Acervo da Biblioteca Municipal Mário de Andrade.

Será nos anos de 1950 e 1951, que os elementos compositivos "reflexos" e "sombras" 285 se tornariam temas para concursos internos do Bandeirante.

Porém se em 1949, quando Lorca e Trevellin participaram do $8^{\circ}$ Salão Internacional de Arte Fotográfica, essa estética já figurava na produção de associados do Bandeirante, isso quer dizer que naquele momento já se prenunciava a consolidação dessas questões.

${ }^{285}$ Ver boletins do Foto Cine Clube Bandeirante ano V n 58 fevereiro de 1950, p. 11 e 12, e $\mathrm{n}^{\circ} 60$ de abril de $1951 \mathrm{p}$. 24 e 25 . 


\section{As aproximações possíveis entre Menina na Chuva}

\section{e Atrás da Estação Saint Lazare}

A questão do espelhamento da imagem na água é um recurso que German Lorca empregará também na fotografia Menina na Chuva, realizada em 1950, para um concurso do Foto-Cine Clube Bandeirante.

Se Lorca estaria pautado nos preceitos de fotografia artística apregoada pelo Foto-Cine Clube Bandeirante, que de maneira explícita ou implícita, abordava questões da straight photograhy, isso significa que sua produção fotográfica se alinhava a um conteúdo estético de origem internacional.

A evolução da idéia de straight photography, ou fotografia direta, resultaria em outros conceitos que unem fotografia e arte como a questão do momento decisivo que está ancorada na captação de uma imagem única, obtida em um instante preciso. Essa idéia se tornaria a principal questão da produção fotográfica de Henri Cartier-Bresson.

Desse modo, a Menina na Chuva de German Lorca descenderá de afiliações estéticas como a de straight photography e a de momento decisivo ${ }^{286}$ - aproximando essa fotografia à Atrás da Estação Saint Lazare, de CartierBresson -, embora falseie a captação de um flagrante para atingir tais parâmetros. E a fotografia Atrás da Estação Saint Lazare, de Henri CartierBresson, descenderá de noções como a straight photography, candid camera

\footnotetext{
${ }^{286}$ A Biblioteca do Bandeirante possui um livro intitulado "All About the Right Moment in action photography (The New Photo Guide)", de autoria de Alex Strasser (Londres e Nova lorque: The Focal Press, 1944). O livro contém um número de tombo (in770 S897r e.2) e está marcado como "livro n 67", mas não consta a data de sua aquisição pela Biblioteca do Clube. Por estar indicado "Foto Cine Clube Bandeirante - Biblioteca Eduardo Salvatore, Rua Avanhandava, 316", supõe-se que a obra foi adquirida ou doada entre 1949 e meados da década de 1970, quando a sede da agremiação localizava-se na Rua Avanhandava. Porém dada a baixa numeração do livro em sua catalogação, supõe-se que a aquisição se deu até os anos 1950. Sobre o histórico das sedes do Foto-Cine Clube Bandeirante ver o site www.fotoclub.art.br
} 
(lembre-se da atuação de Erich Salomon) e a nova objetividade, embutidas na base da idéia de momento decisivo.

Sob esse aspecto, quatro anos antes de Cartier-Bresson realizar a fotografia Atrás da Estação Saint Lazare, em 1932, Friedrich Seidenstucker fez a fotografia Bearing the Load, inserido no contexto da nova objetividade alemã, o que leva a crer que Bresson poderia estar atento às influências dessa estética quando captou a imagem de Atrás da Estação Saint Lazare [Ilustração 2.21].
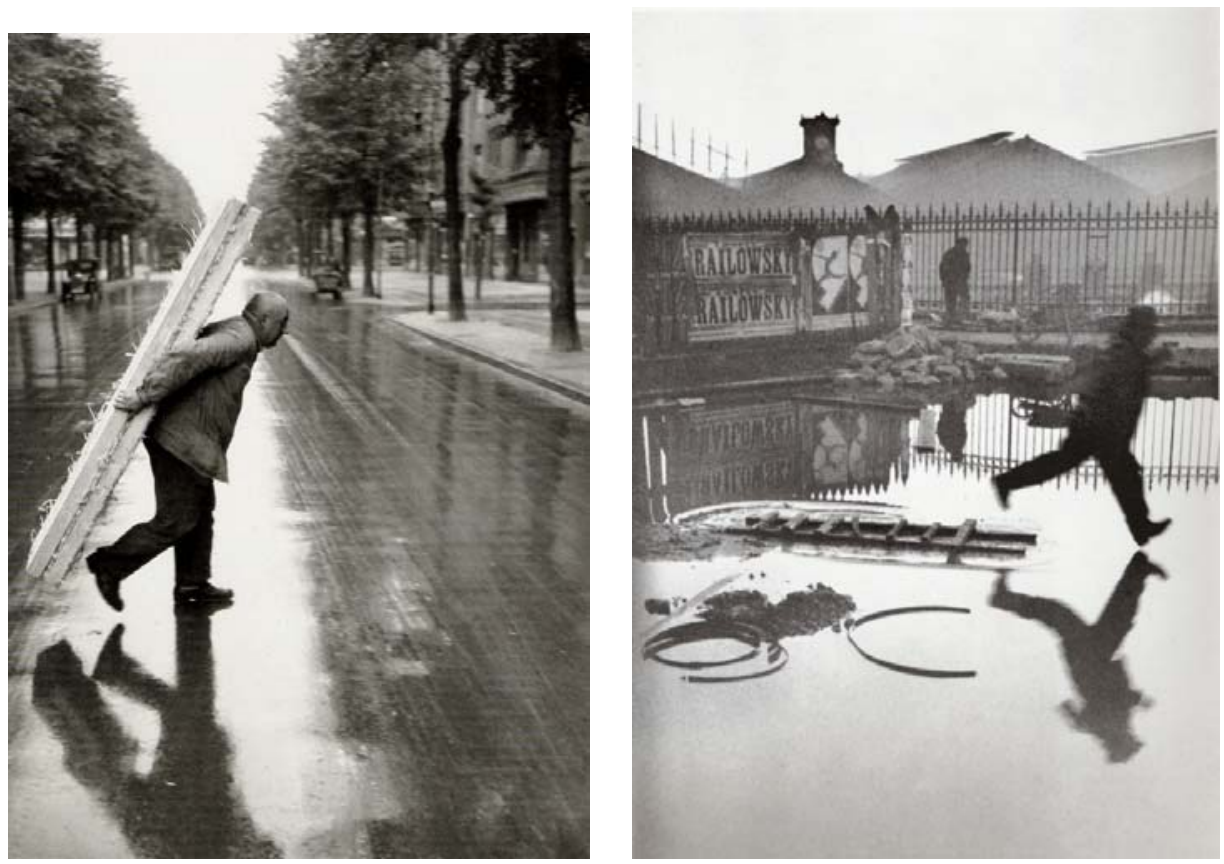

Ilustração 2.21: Friedrich Seidenstucker, Bearing the Load, 1928 (a esquerda) e Henri Cartier-Bresson. Atrás da Estação Saint Lazare, 1932.

Partindo agora para as aproximações possíveis entre as fotografias Atrás da Estação Saint Lazare [Ilustração 2.22] e Menina na Chuva [Ilustração 2.23], cabe observar primeiro os resultados estéticos: 

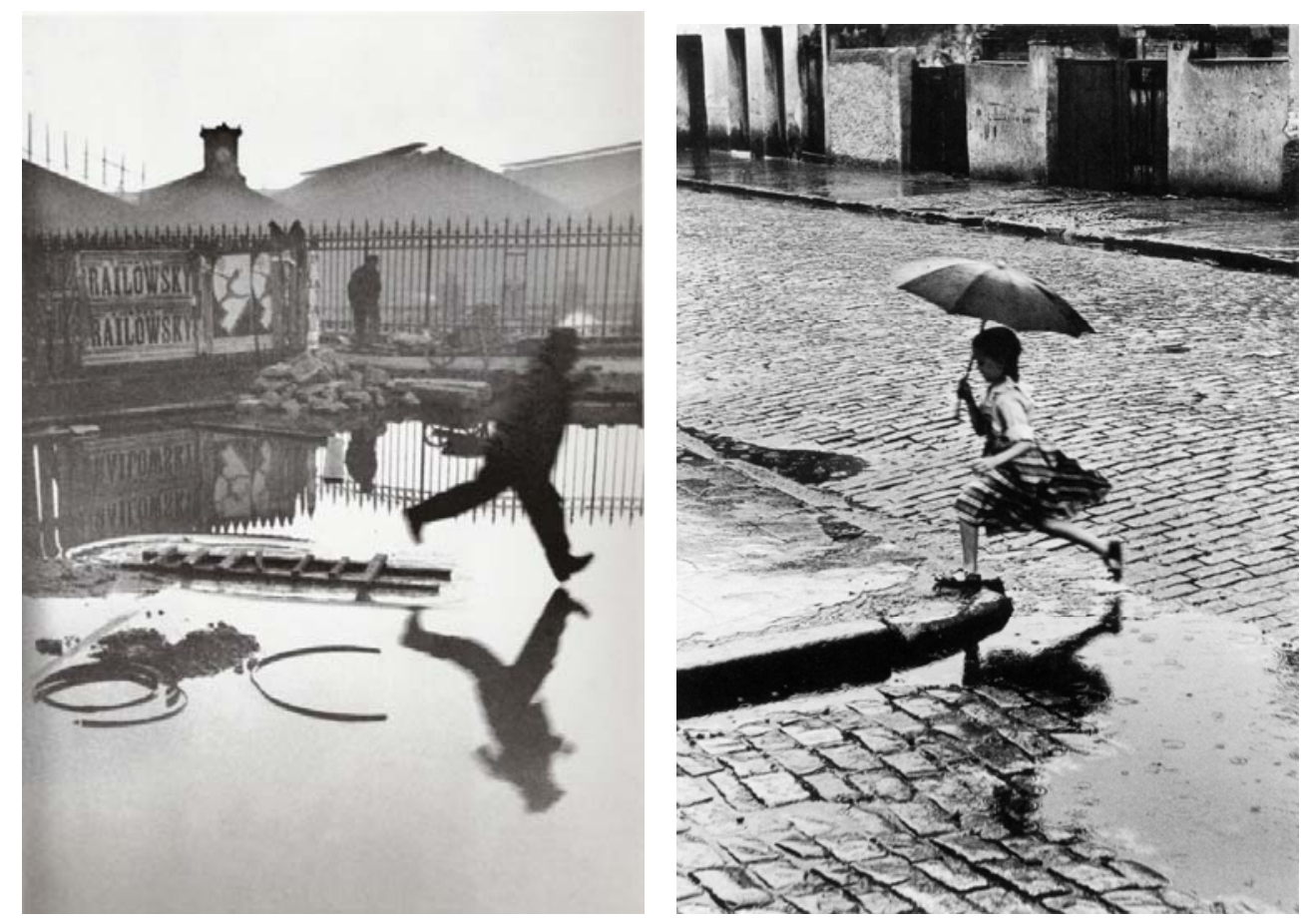

Ilustrações 2.22 e 2.23: Henri Cartier-Bresson. Estação Saint Lazare, 1932, à esquerda, e German Lorca. Menina na Chuva, 1950, à direita. Coleção Museu de Arte Moderna de São Paulo.

As duas fotografias mostram imagens de pessoas pulando poças de água com suas imagens refletidas nela. Na fotografia de Bresson o reflexo do homem se duplica na água e, sugere-se a triplicação da imagem por meio de um cartaz colado na parede.

A fotografia de Cartier-Bresson é mais descentralizada - a figura do homem saltando se aproxima da borda direita como se ele fosse sair da fotografia. Em Menina na Chuva, a menina está bem no centro da imagem e seu salto se dá em direção à calçada do lado esquerdo da fotografia.

A questão central para a aproximação dessas imagens é a do registro do pulo como resultado de uma ação flagrada ou encenada.

A Menina na Chuva de German Lorca, não nos dá pistas de que é um pseudoflagrante quando a olhamos. O que se vê na imagem é o registro de um 
pulo congelado: houve um flagrante de um pulo, por certo. Sabemos que é um pseudoflagrante porque o próprio Lorca conta sobre a encenação.

Com relação à fotografia Atrás da Estação Saint Lazare, é também o próprio Cartier-Bresson que conta como tal imagem foi obtida:

\begin{abstract}
Havia uma fenda próxima às reformas atrás da Estação Saint Lazare. Eu estava na fenda observando no momento que o homem pulou. O espaço existente na fenda não era inteiramente suficiente para as minhas lentes, motivo pelo qual a imagem é cortada à esquerda ${ }^{287}$.
\end{abstract}

Nesse ponto, entra a questão do corte. Embora Henri Cartier-Bresson pregasse que a composição "devia se dar no olho", em algumas poucas imagens ele se utilizava do recurso do corte, como em Atrás da Estação Saint Lazare:

Georges Fevre trabalhou durante mais de três décadas com as fotos de CartierBresson no lendário laboratório Picto. Alinhavaram uma cumplicidade rara. Na ponta do lápis, Fevre tem os números que transformam o repórter num monstro sagrado. "Dos 17 mil filmes com 36 poses, num total de 700 mil registros, apenas duas ou três fotos de Cartier-Bresson foram reenquadradas", diz Fevre. Uma delas é a imagem da Gare Saint Lazare. Ele sempre foi muito atento à traição com as imagens. Impunha às redacções (sic) um fio negro ao redor das fotos, de modo a evitar cortes. Cuidados desse gênero transformaram-no no olho do século $X X-$ e ajudaram a tirar as fotografias do papel de imprensa para levá-las ao museu ${ }^{288}$.

\footnotetext{
287 Ver descrição da imagem Atrás da Estação Saint Lazare no link http://www.magnumphotos.com/c/htm/CDocZ MAG.aspx?Stat=DocThumb DocZoom\&o=\&DT=ALB\&E=29YL53KGUTK \&Pass $=\&$ Total=349\&Pic=18\&SubE=2S5RYDI9CNRQ . "Paris. Place de l'Europe. Gare Saint Lazare. 1932. There was a plank fence around some repairs behind the Gare Saint Lazare train station. I happened to be peeking through a gap in the fence with my camera at the moment the man jumped. The space between the planks was not entirely wide enough for my lens, which is the reason why the picture is cut off on the left."

288 Ver artigo "O valor do instante decisivo", datado de 12 de maio de 2005 no site http://tassebem.com/artigo.php?id=1459 . Esse mesmo artigo informa que a fotografia Atrás da Estação Saint Lazare
} 
Para German Lorca, o fato de cortar a fotografia na busca por torná-la melhor resolvida compositivamente, será um ato comum e não uma exceção, como em Cartier-Bresson. Além disso, o corte que Lorca aplica nem sempre será modesto, para um pequeno reparo. A fotografia original de Menina na Chuva nos mostra que foram retiradas informações que a tornavam um documento sobre a configuração da Rua Almirante Barroso, no Brás, no início da década de 1950, transformando completamente a sua leitura. Contudo, até chegar no resultado final, eliminando praticamente a referência das casas, Lorca procedeu cortes intermediários [llustração 2.24]:
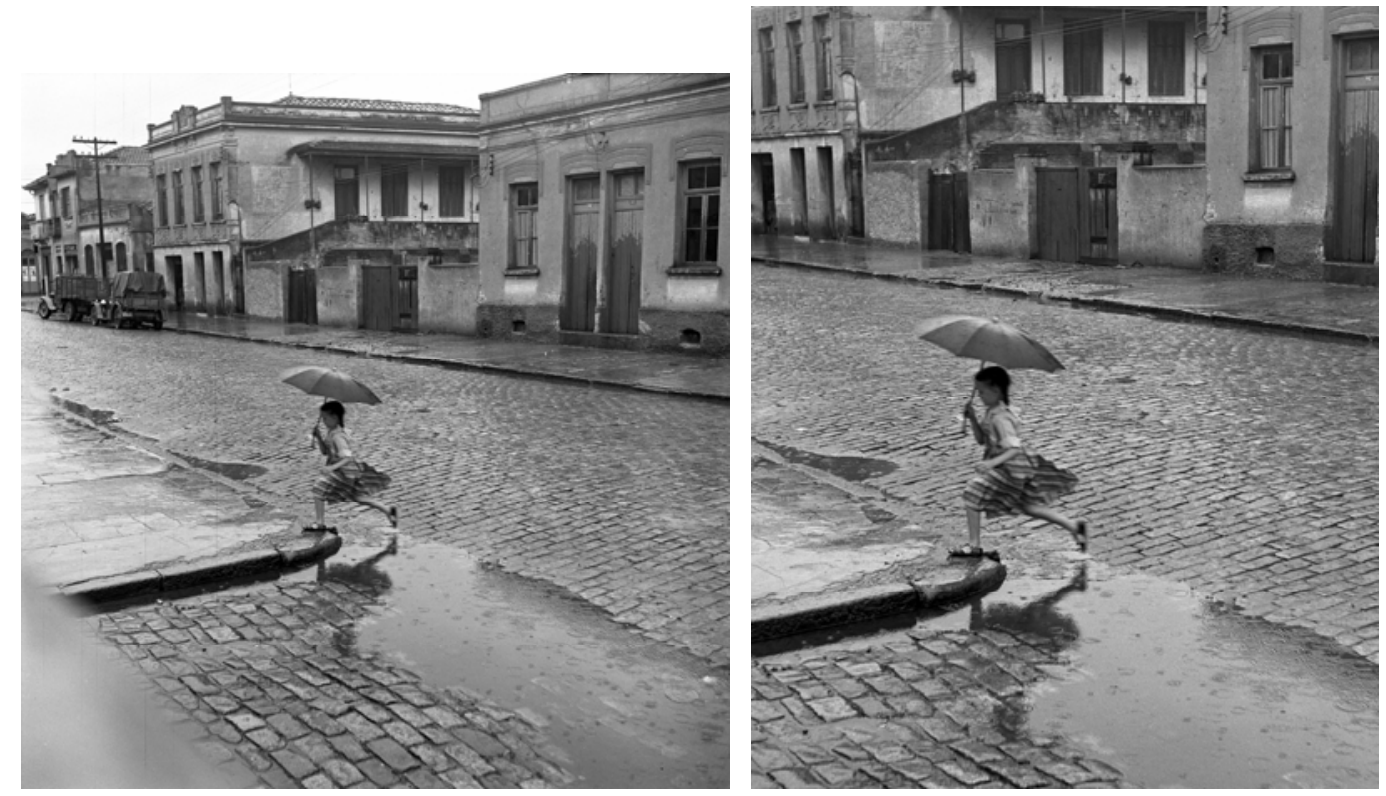

Ilustração 2.24: German Lorca. Menina na Chuva, 1950. Fotografia original (à esquerda) e com corte intermediário (à direita). Acervo de German Lorca.

foi feita com um "disparo a uma velocidade de 1/125. Um átimo de segundo depois, ou antes, e a fotografia não existiria". 
Essa questão do corte em Menina na Chuva e em outras fotografias de German Lorca será melhor estudada no próximo capítulo.

\title{
$\S \S \S \S \S$
}

\section{CAPÍTULO 3: O flagrante, o pseudoflagrante e a composição na}

\section{fotografia de German Lorca.}

\begin{abstract}
(...) Sempre faço corte, quando você tira flagrante, que é coisa que acontece, você não está preocupado com o tamanho do negativo, você está preocupado com a foto. Ai você tem que enquadrar a imagem para fazer a composição funcionar. Quer dizer, a composição leva à leitura melhor da fotografia. Se você não tiver a composição às vezes não leva a leitura.

German Lorca (Entrevista concedida à autora em 01 de dezembro de 2004).
\end{abstract}

Tanto quanto o flagrante autêntico, o falseamento do flagrante será um recurso que Lorca lançará mão em suas fotografias de rua, começando a praticá-lo no âmbito do Foto-Cine Clube Bandeirante. Em ambos os casos, a questão principal para o fotógrafo será o resultado final da imagem que deve apresentar boa composição. Para atingi-la, Lorca se valerá do corte na imagem sempre que considerar necessário.

Porém, ao mesmo tempo em que trabalhava a composição em flagrantes e pseudoflagrantes Lorca o fazia em fotografias de outras categorias. 
Esse fato torna-se claro ao se observar as fotografias com as quais ele teria participado do concurso Dias de Chuva, em 1950: Menina na Chuva, Homem na Chuva [Ilustração 3.1] e Chuva na Janela ${ }^{289}$ [llustração 3.2].

\title{
O concurso anunciava:
}

\begin{abstract}
"Dias de chuva" é o tema programado para o concurso interno de junho próximo. Têma (sic) dos mais sugestivos e que, tratado com gosto e sentimento, poderá proporcionar quadros dos mais ricos em força expressiva, numa variedade enorme de motivos, desde a paisagem, cênas (sic) de rua, até um simples detalhe de uma poça de água ou de um pingo de chuva. Aguardemos, pois, o próximo concurso, na certeza de que podemos apreciar lindas e sugestivas fotografias $(\ldots)^{290}$
\end{abstract}

Assim, entre as cenas de rua, Lorca inscreve os pseudoflagrantes Menina na Chuva e Homem na Chuva. Se usa a sobrinha Eunice para produzir Menina na Chuva, Lorca utiliza como modelo o seu irmão Francisco Lorca Lopez, para encenar Homem na Chuva $(1950)^{291}$. Ao contrário da primeira, Homem na Chuva fornece pista de que foi arranjada em nome de uma composição: o guarda-chuva cuidadosamente posicionado no batente esquerdo da porta. Lorca conta que esse guarda-chuva foi lá colocado intencionalmente e que a fotografia foi feita do interior da mesma casa na Rua

\footnotetext{
${ }^{289}$ Depoimento concedido a autora em entrevistas realizadas ao longo de 2004 e em 04 de agosto de 2005. A primeira vez que German Lorca mencionou o concurso Dias de Chuva foi em 15 de abril de 2004. Não há nenhuma menção nos boletins relativos ao concurso, quais foram as fotografias inscritas pelos participantes. O FCB Boletim Ano V, $n^{\circ} .51$ de julho de 1950 apenas traz as fotografias que obtiveram melhor classificação no concurso.

${ }^{290}$ Ver FCB Boletim Ano V, $\mathrm{n}^{\circ} .51$ de julho de 1950.

291 Embora a data oficial desta fotografia seja 1952, na coleção do Museu de Arte Moderna de São Paulo (MAM-SP), pelas entrevistas que realizei com German Lorca entre 2004 e 2005, Homem na Chuva e Menina na Chuva, são do mesmo ano, 1950, uma vez que foram realizadas para o concurso Dias de Chuva. No entanto, Lorca diz considerar como data oficial da fotografia, o ano em que foi exposta pela primeira vez. Este estudo não localizou dados concretos a respeito da participação da fotografia Homem na Chuva em alguma exposição do ano de 1952.
} 
Almirante Barroso, na qual residia quando realizou o pseudoflagrante com Eunice $^{292}$.
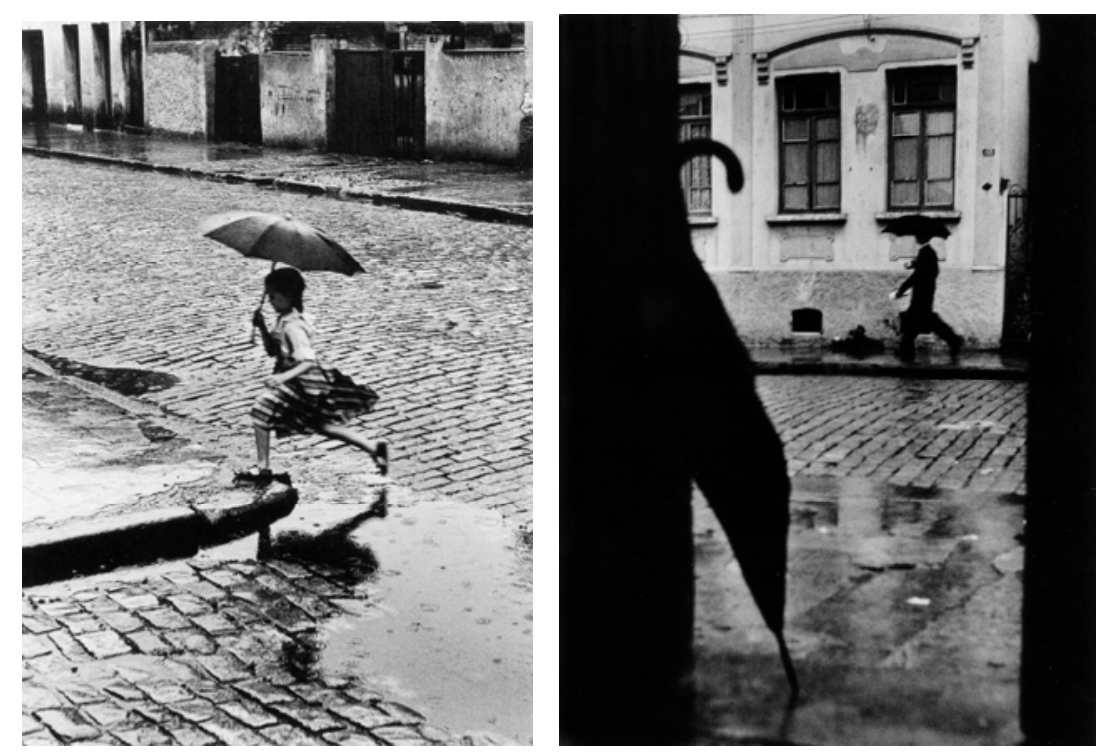

Ilustração 3.1: Pseudoflagrantes realizados por German Lorca para o Concurso Dias de Chuva: Menina na Chuva, 1950 (à esquerda) e Homem na Chuva 1950 (à direita). Coleção Museu de Arte Moderna de São Paulo.

Aó Fotogratias do Mês

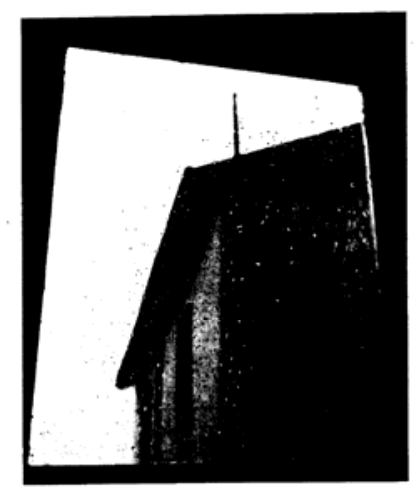

Ilustração 3.2: A fotografia Chuva na Janela, publicada no FCB Boletim Ano V, nº. 51 de julho de 1950. Acervo Foto-Cine Clube Bandeirante/Arquivo Pessoal de German Lorca

${ }^{292}$ Entrevista concedida à autora em 15 de abril de 2004. 
Referente à idéia de fotografias que mostrassem detalhes de "pingos de chuva”, Lorca inscreve e é classificado com Chuva na Janela.

A atitude de Lorca de inscrever fotografias em categorias diversas, "cenas de rua" e "detalhes de pingos", demonstra que o fotógrafo não tinha completa certeza de qual categoria participar. Apostou em ambas as possibilidades, ao invés de uma só. E ainda assim "desobedece" aos preceitos de flagrantes preconizados pelo Bandeirante, enviando pseudoflagrantes para o concurso:

Quem se aventura ao registro de cenas de rua, deve ser bastante desembaraçado para não ligar à curiosidade dos que passam, aos 'basbaques' que logo se aproximam, aos 'técnicos' de calçada e outras preciosidades desse mesmo quilate. $\mathrm{O}$ trabalho do fotógrafo deve ser realizado com inteira independência, sem ligar a menor importância aos circunstantes e dando um ar mesmo de quem não quer saber de nada, com quem quer que seja. Si o amador começa a porejar, enrubecer, ou demonstrar qualquer vestígio de encabulamento, então está perdida, de início, a qualidade artística da sua cena de gênero. Si ocorre esse descontrole emocional, como poderá o fotógrafo observar a beleza de sua enquadração, a rapidêz de seu disparador, o seu diafragma, os planos, seu ângulo de tomada? Evidentemente, tudo irá sair ao 'Deus dará' e nós já sabemos onde vão ter os negativos de cenas desta forma colhidas... Portanto, trabalhe com amplo domiínio de si e dos 'curiosos'. Faça a sua fotografia como se estivesse em seu 'studio', ou no quintal de sua residência. Enquadre, diafragme, componha e pronto $(\ldots)^{293}$

Das quatro fotografias que obtiveram melhor classificação no concurso Dias de Chuva, além de Chuva na Janela, de German Lorca, outras duas

\footnotetext{
${ }^{293}$ Ver VICTOR, Antonio S. O Fotógrafo e as cenas de Gênero. In: Foto-Cine Boletim, nº 60, abril de 1951. p. 8.
} 
apresentavam a mesma noção compositiva formalista: Fé, de Eigyrio Sato e Sinal Fechado, de Abílio M. Castro [llustração 3.3].

Ad Fotografiad do Med

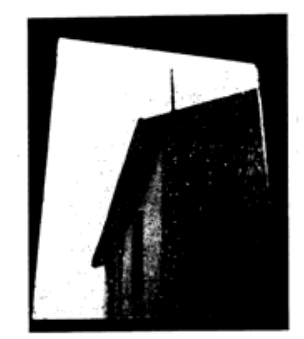

$=$

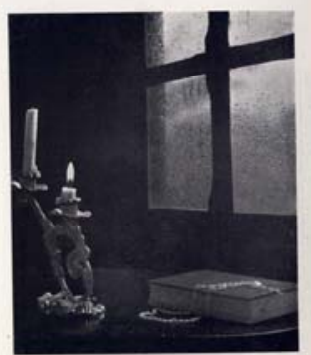

-

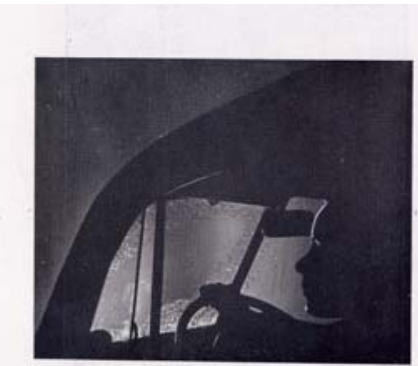

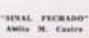

Ilustração 3.3: Da esquerda para a direita: Chuva na Janela, de German Lorca; Fé, de Eigyrio Sato, e Sinal Fechado, de Abílio M. Castro. Acervo Foto-Cine Clube Bandeirante.

A tomar por essas imagens, o Bandeirante parecia oscilar, nesse momento, não sabendo optar por obras com certa aproximação da straight photography (caso das fotos de Lorca e mesmo a de Abílio M.Castro) ou por aquelas de tema mais próximo do pictorialismo (caso da foto de Eigyrio Sato e de Arnaldo Florence) $)^{294}$.

Por outro lado, é interessante sublinhar que neste período o próprio Lorca parece oscilar entre parâmetros distintos: se opta pela encenação do flagrante das duas obras acima comentadas, em Chuva na Janela busca aproximar-se da fotografia direta.

\section{§§§§§}

A prática do pseudoflagrante está vinculada a dois fatores principais. $\mathrm{O}$ primeiro será o exercício da fotografia amadora na qual, geralmente, são

\footnotetext{
${ }^{294}$ Para visualizar a fotografia ...E a chuva caía ... de Arnaldo M. Florence,consultar Boletim Ano V, n 51,julho de 1950.
} 
retratados os familiares ou amigos de quem fotografa, situação que facilitará a possibilidade de encenação. O segundo - o assunto deste capítulo -, a composição e o corte como ferramentas de aperfeiçoamento estético da imagem obtida.

Em nome de atingir o status de fotografia de arte, German Lorca tanto irá flagrar ou pseudoflagrar cenas, como irá utilizar-se do corte.

Parece que seu intuito, na verdade, era resolver a composição da foto em um segundo momento, estudando os cortes necessários para enfatizar este ou aquele aspecto da cena, deixando, sob esse aspecto, de ter relevância se os fatos registrados eram ou não forjados ${ }^{295}$.

É importante ter em mente que, para o fotógrafo, a composição final da imagem será sempre uma questão fundamental, que esteve em seu horizonte desde os tempos de Foto-Cine Clube Bandeirante.

Ele mesmo menciona a importância da composição para a realização de suas fotografias ao longo das diversas entrevistas que concedeu à autora: "Eu obedeço muito as regras de composição que o Geraldo me ensinou. Veja que nessa fotografia tem as linhas de composição: sobe, tem a leitura, os espaços ocupados, entendeu? Composição é muito importante na fotografia ${ }^{296 " . ~}$

Lorca se refere à amizade que tinha com Geraldo de Barros quando ambos atuavam no Foto Cine Clube Bandeirante e à fotografia Tetos Brancos $^{297}$, que foi publicada no Foto-Cine Boletim de outubro de 1951 [llustração 3.4]

\footnotetext{
${ }^{295}$ Historicamente, como se verá em "Considerações Finais" fará toda a diferença descobrir que uma fotografia que era tida como flagrante, na verdade foi forjada.

${ }^{296}$ Depoimento concedido à autora em 15 de abril de 2004.

297 Tetos Brancos participou do $10^{\circ}$ Salão Internacional de São Paulo, do ano de 1951. Ver Foto Cine Boletim Ano VI, Outubro de 1951, página 13. Essa fotografia seria publicada sob o título de Telhados no catálogo da II Bienal de Curitiba, com a data equivocada: 1969.
} 

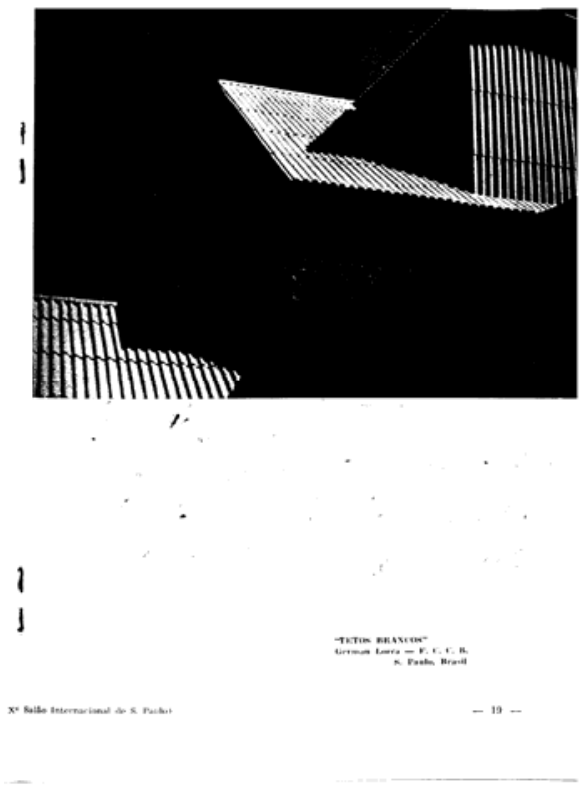

Ilustração 3.4: Tetos Brancos, German Lorca, 1951. Acervo Foto-Cine Clube Bandeirante.

Será no Foto Clube que Lorca irá aprender regras de composição, tais como profundidade, utilização de sombras/reflexos, ênfase no tema, o equilíbrio entre as formas, etc., as quais jamais questionaria.

Essas regras, assim como as diversas técnicas fotográficas, além de temas relativos ao exercício fotografia, eram difundidos em eventos como os Seminários Internos e também nos Boletins do Bandeirante.

Durante sete números do Boletim ${ }^{298}$, o fotógrafo Aldo A. de Souza Lima, por exemplo, publicou, um artigo sobre composição.

Logo na introdução do artigo, Souza Lima nos fornece dados sobre o peso que a questão da composição terá dentro do âmbito do Bandeirante nos anos 1950:

\footnotetext{
${ }^{298}$ Ver boletins: Ano $V-n^{\circ} 50$, de junho de 1950, págs. 6 a $9 ; n^{\circ} 51$ de julho de 1950, págs 6 a 8 ; Ano $V-n^{\circ} 52$ de agosto de 1950; Ano $V-n^{\circ} 53$ de setembro de 1950; Ano $V n^{\circ} 54$ de outubro de 1950; Ano $V-n^{\circ} 55$ de novembro de 1950 e Ano $V-n^{\circ} 56$ de dezembro de 1950.
} 
Um dos temas obrigatórios nas costumeiras arengas, diante de um trabalho qualquer, em nosso Clube é, sem dúvida, a Composição. Não só é obrigatório como também motivo a pendências que, mal solucionadas, deixam, regra geral, após si, uma atmosfera nebulosa de incompreensão. Tal acontece atualmente, é óbvio, em virtude do rápido desenvolvimento que se vem apreciando no valor artístico dos trabalhos, do número cada vez maior de novos praticantes e também da alteração da forma de julgamento dos nossos concursos internos, em sua nova papeleta. Nesta, em seu item terceiro, lá está o famigerado tópico: COMPOSIÇÂO (... $)^{299}$

Nessa mesma introdução Aldo de Souza Lima coloca como objetivo procurar que se conheçam:

(...) todos os rudimentos da Composição em seus mais variados aspectos, a fim de que possamos apoiar o nosso desenvolvimento artístico em fundamentos sólidos. Depois nos libertaremos dando largas á (sic) emotividade individual, sem cogitações imediatas de ordem escolástica $(. . .)^{300}$

Na segunda parte, Souza Lima apresentará um esquema que constitui os princípios básicos (dominância, equilíbrio e contraste) e secundários (centros de fixação, acentos) da composição, os quais serão aprofundados até a conclusão do artigo, e resume que:

Deste estudo concluiremos, portanto, que a boa composição apresenta, em última análise: uma força de atração que gera o movimento da vista, uma região de dominância a que todo o conjunto é subordinado e, finalmente, todos os seus elementos acham-se em equilíbrio $(. . .)^{301}$

\footnotetext{
${ }^{299}$ Ver boletim Ano V, n 49, junho 1950, p. 6.

${ }^{300}$ Idem, ibidem.

${ }^{301}$ Ver boletim Ano V - $n^{\circ} 51$, julho de 1950. Na página seguinte ao encerramento da segunda parte do artigo de Souza

Lima, encontra-se o artigo "A Arte Fotográfica de Edward Weston", sobre sua estética fotográfica, a straight
} 


\section{$\mathrm{Na}$ conclusão de seu artigo sobre composição, o autor menciona o retrato solarizado Le Diables aux Corps [llustração 3.5], realizado por German Lorca, como referência de composições "propriamente ditas", isto é, aquelas} que: se impõem por si mesma sem se estribarem em qualquer conceito, esquema ou dogma pré-estabelecido. É a composição própria, individual, única para um determinado trabalho. O artista ao sofrer o processo subjetivo da creação sente a fórma composicional sem que, posteriormente, a possa definir. (...) São estas fórmas as de maior valor artístico pois são originais e determinam, como tal, o grau de elevação creadora e estética do autor ${ }^{302}$.

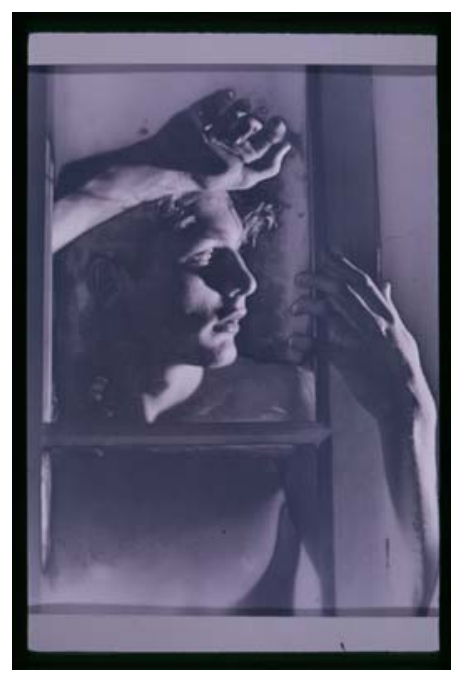

Ilustração 3.5: German Lorca. Le Diable au Corps, 1950. Acervo de German Lorca (slides).

photography, do qual este estudo destaca dois trechos que considera oportunos, principalmente ao se pensar que acaba-se de se encerrar um artigo de uma aula de composição no Bandeirante que parece ser complementado com o artigo sobre Weston: "A fotografia é o meio de captar o momento - não importa qual o momento, mas o momento importante, aquele único momento entre todos, onde o seu assunto é pelenamente revelado - aquele momento da perfeição, que surge uma vez e não mais se repete" Ed. Weston. "(...)sobre a objetividade e a pureza dos meios utilizados na realização fotográfica, simplificados ao extremo e não tendo senão em vista a qualidade, a beleza e a perfeição dos resultados. É dessa época sua decisão, verdadeiramente arrojada, de abandonar as ampliações porque, conforme o afirmava 'não desejava correr o risco de perder os valores mais subtis...': deixa de lado o retoque - 'que é uma ilusão sinão (sic) mesmo uma deformação', não mais procede suas revelações pelo sistema de quadros, por saber ser possível obter maiores resultados pelo sistema de chapas e lança a cópia direta em grande formato". É também neste boletim que figura entre "As fotografias do Mês" , a fotografia "Chuva na Janela", de German Lorca.

${ }^{302}$ Esta citação segue a grafia da época. Ver Boletim Ano V - n' 56 de dezembro de 1950. 
Apesar de ser um retrato ${ }^{303}$ e não uma fotografia de rua, o fato de uma fotografia de autoria de Lorca ser mencionada dessa forma no artigo mostra o quanto o fotógrafo estava envolvido com a questão da composição, durante a sua atuação no Clube.

A questão explícita do corte estará presente principalmente em artigos publicados em boletins entre os anos de 1951 e 1952, como Corte, Interpretação e Princípios de Composição ${ }^{304}$, de autoria de Antonio da Silva Victor, Porque introduzir Modificações?, escrito por D. Ward Pease e O que é o corte de ouro? ${ }^{305}$, assinado por John S. Echersley:

Dentro do inesgotável campo de manifestações subjetivas que a fotografia proporciona, especialmente quando um mesmo assunto é objeto de exame e crítica por parte de dois ou mais fotógrafos experimentados, encontramos com freqüência duas posições que quase sempre se repetem: a interpretação rigorosamente pessoal; afetiva e a observância total das práticas recomendadas pela estética(... $)^{306}$

Essa relação entre o corte, a interpretação e os princípios de composição que é justamente o que Lorca faz. O corte seria o elemento necessário para a "observância total das práticas recomendadas pela estética".

Outra consideração importante a respeito do corte dá conta de que:

\footnotetext{
${ }^{303}$ Embora não se trate de uma fotografia de rua e portanto de ,um flagrante ou pseudoflagrante, Lorca contou em uma palestra realizada no Itaú Cultural em 04 de outubro de 2005, que utilizou como modelo um amigo artista de Geraldo de Barros.

${ }^{304}$ Ver Boletim ano $\mathrm{VI}-\mathrm{n}^{\circ}$ 63, julho de 1951.

${ }^{305}$ Ver Foto-Cine Boletim Ano VI, n 61e 63, maio e julho de 1951; Ano VI - no 69/70 jan./fev. 1952.

${ }^{306}$ Ver VICTOR,Antonio da Silva.Corte interpretação e principio de composição.In: Boletim ano VI - $n^{\circ} 63$, julho de 1951.
} 
Um dos mais elementares (..) "controles" é o que comumente denominamos "corte". Seria sumamente interessante si sempre pudéssemos tomar nossas fotografias num ângulo determinado, permitindo-nos a utilização integral do negativo contendo, exatamente, tudo aquilo por nós desejado. Para obter isto devemos possuir, primeiramente, uma visão muito educada e um senso fotográfico bastante desenvolvido (...) Quasi sempre as condições não nos permitem tempo suficiente para explorar as redondezas e encontrar aquele ponto ideal para o registro de nosso assunto (...) Essa habilidade para avaliar a porção necessária do negativo para ampliação, desprezando o supérfluo, é, geralmente o primeiro passo do "contrôle" realizado pelo fotógrafo no laboratório $^{307}$.

Essa questão de cortar a imagem por não tê-la obtido no ângulo correto, de modo a conter tudo aquilo que o fotógrafo deseja, isto é, de selecionar o assunto, é seminal para a análise da prática do corte nos flagrantes e pseudoflagrantes de Lorca.

Este estudo tomará como exemplos, para as considerações acerca da composição e do corte, as seguintes fotografias de autoria de Lorca: Cortiço no Brás (1949), Malandragem (1949); Menina na Chuva, A Procura de Emprego (1950) e Apartamentos (1951).

A fotografia Cortiço no Brás [llustração 3.6], com corte, foi apresentada por Lorca no $3^{\circ}$ Seminário de Arte Fotográfica do Foto-Cine Clube Bandeirante, em 1949, e discutida por associados, como Geraldo de Barros e pelo orientador do seminário, Eduardo Salvatore, em termos que interessam a este estudo.

\footnotetext{
${ }^{307}$ Manteve-se a grafia original da época. Ver Foto-Cine Boletim Ano VI, $n^{\circ} 61$, maio de 1951, p. 11.
} 

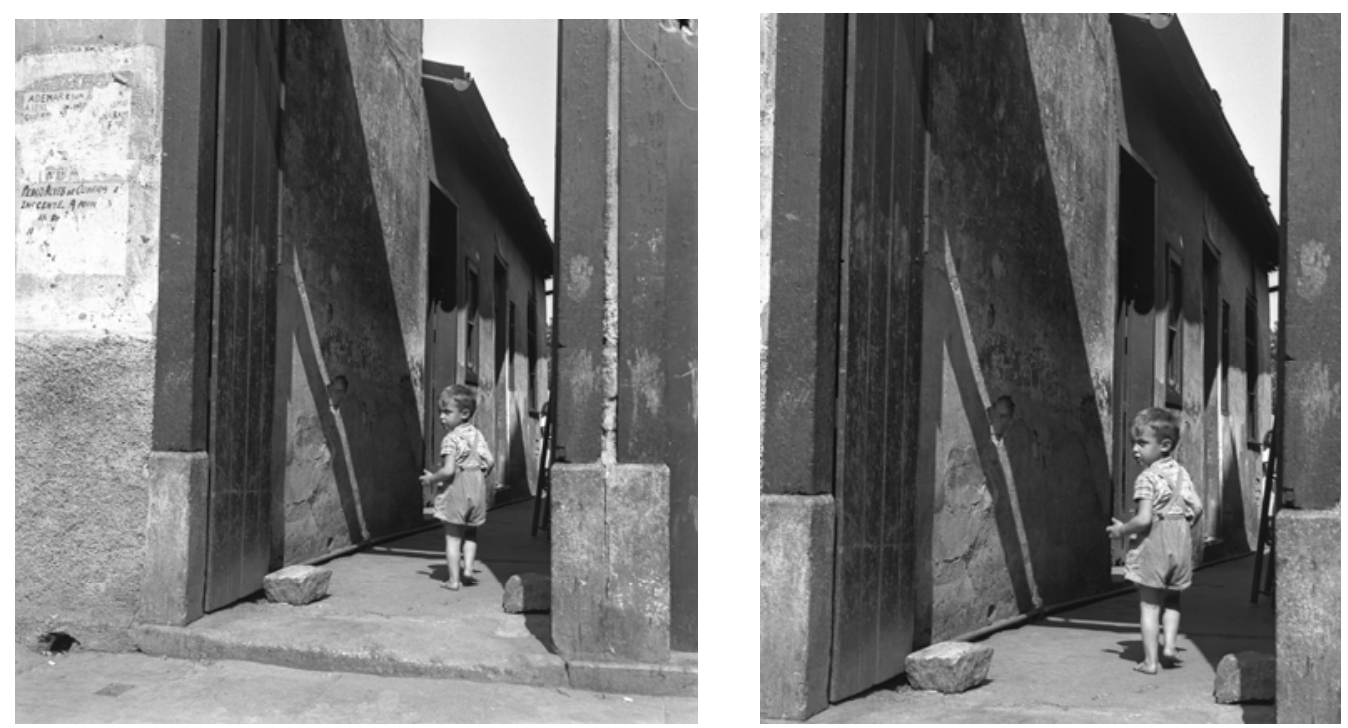

Ilustração 3.6: German Lorca. Cortiço no Brás, 1949. Fotografia original (à esq.) e com corte (à direita.). Acervo de German Lorca e Coleção Museu de Arte Moderna de São Paulo.

Segundo consta do boletim que relata o seminário, Lorca tinha "tido a idéia de realizar uma fotografia que representasse um cortiço, com todas as peculiaridades de seus problemas sociais: colheu o instantâneo em apreço, aproveitando a figura do menino ao entrar no estreito corredor ${ }^{308}$ ".

A essa afirmação, Geraldo de Barros contestou: "Parecia-lhe não ter sido o autor totalmente feliz, não havendo, ao que julga, estudado o autor previamente o local. A fotografia não reproduz propriamente um cortiço, nem dá a idéia de ambiente próprio ${ }^{309 ”}$.

E o boletim assim apresenta a resposta de Lorca ao comentário de Barros: "De fato, dada a dificuldade do assunto e para não chamar a atenção do figurante colheu o 'instantâneo' em apreço ${ }^{310 ”, ~}$

\footnotetext{
${ }^{308}$ Ver Boletim Ano IV - n 42, outubro de 1949. Ao que podemos deduzir por meio desse boletim, a fotografia Cortiço no Brás, que lá figura apenas como Cortiço, teria sido realizada naquele ano e não em 1952, quando possivelmente seu título foi revisto.

${ }^{309}$ Idem, ibidem.

${ }^{310}$ Idem, ibidem.
} 
Além dos comentários de Geraldo de Barros, o orientador do seminário, Eduardo Salvatore, teria observado que nem sempre é:

o "instantâneo" - assim entendido a rapidez da ação do fotógrafo - o método de ação mais indicado para assuntos como o da fotografia. Em cenas de rua - tema que o autor, já nos apresentou ótimos trabalhos - muitas vezes deve assim agir o fotógrafo para apanhar a cena e seus figurantes com toda a naturalidade, no momento mais indicado que se quer expressar. Quando, porém, se quer retratar ambientes, deve-se fazer um estudo acurado do local, suas condições de iluminação, ângulo mais adequado, etc. e a própria colocação das figuras e suas atitudes devem ser cuidadosamente observadas, dispondo-se os elementos no quadro em função do próprio conceito a ser expresso fotográficamente (sic) $)^{311}$.

Postas essas considerações pode-se tirar algumas conclusões: tanto Geraldo de Barros quanto Eduardo Salvatore questionam, fundamentalmente, o fator "composição" na fotografia de Lorca, uma vez que ponderam sobre o estudo prévio do local da foto, de modo a reproduzir propriamente o ambiente do cortiço, enquanto Lorca coloca em pauta a questão do instantâneo, creditando a este a impossibilidade de tratar devidamente o assunto (um cortiço), para não chamar a atenção do fotografado.

De posse da fotografia original (que não foi mostrada no seminário do Bandeirante, cabe rememorar), podemos notar que Lorca, ao cortar a fotografia, privilegia uma composição que valorize a figura do garoto em contraste com a sombra do telhado de uma das casas, optando por não deixar à mostra elementos da entrada do cortiço, como os cartazes colados na parede.

\footnotetext{
${ }^{311}$ Idem. ibidem
} 
O corte aqui é uma questão fundamental para a leitura que Lorca parece ter desejado oferecer de Cortiço no Brás ao observado: valorizar a figura do menino captada no instantâneo, que pode simbolizar o cotidiano da vida em um cortiço e a falta de perspectivas de uma criança nesse contexto.

Malandragem [llustração 3.7] é uma fotografia altamente codificada, inserida no hall de pseudoflagrantes de German Lorca. Por questões metodológicas, o original dessa fotografia será analisado como pseudoflagrante para depois se tecer considerações a respeito do corte, que a transforma radicalmente.
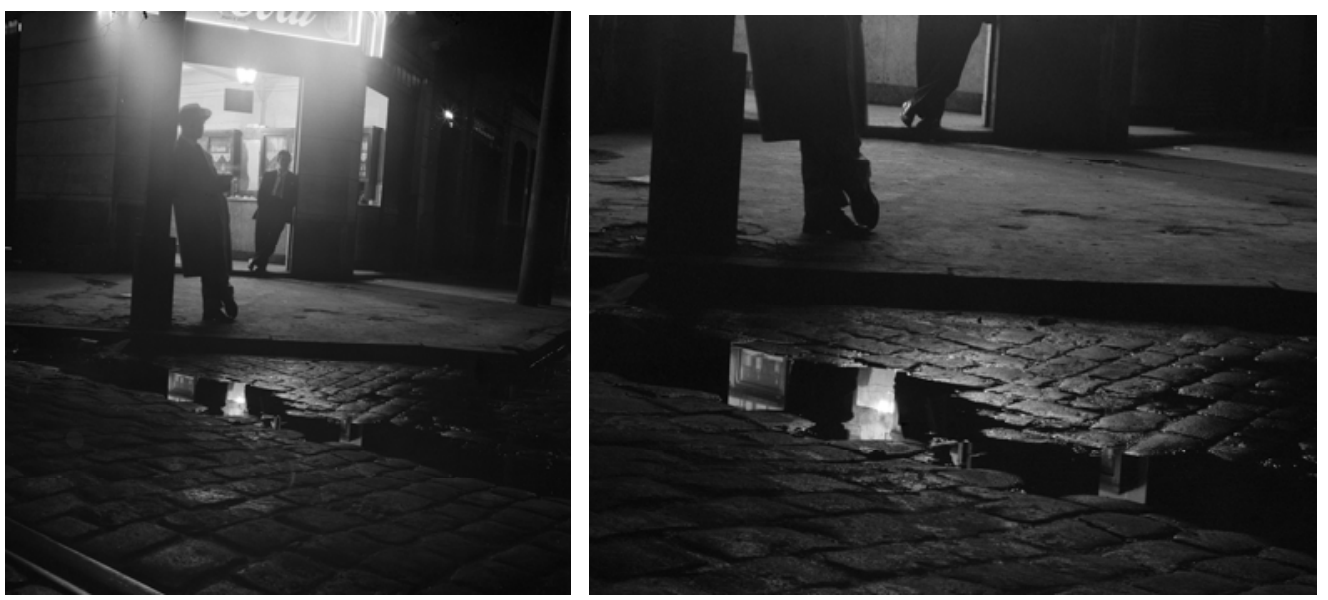

Ilustração 3.7: German Lorca. Malandragem, 1949. Original e com corte, respectivamente. Acervo de German Lorca e Coleção Museu de Arte Moderna de São Paulo.

Na fotografia original, dois homens estão posicionados frente a frente em uma distância que percorre determinado trecho da rua: um está apoiado em um poste e o outro na borda da porta de um bar. Lorca tanto poderia ter flagrado tal cena, de alguma espécie de desafio, entre os dois homens, assim como ter encenado tal fato.

Segundo entrevista com o autor ${ }^{312}$, essa fotografia foi feita no bairro do Brás, tendo ele pedido para dois homens, que estavam no bar, posarem para a fotografia.

${ }^{312}$ Entrevista concedida à autora em 06 de Maio de 2004. Lorca comenta pela primeira vez que Malandragem é um pseudoflagrante na entrevista realizada em 22 de outubro de 2003. Em 01 de dezembro de 2003, em resposta ao meu 
Entendo que a fotografia original Malandragem serviu de estudo para a fotografia final que German Lorca iria apresentar em diversos salões do Bandeirante, com um corte tão dramático.

Aqui se retomam as idéia dos artigos de Victor e de Pease, sobre a relação entre corte e interpretação no resultado estético da imagem e sobre a seleção da imagem, respectivamente.

Com o corte, Lorca tornou Malandragem uma fotografia que discute questões centrais da Fotografia como os planos fotográficos, e a fotografia como representação do real e o exercício da visão ${ }^{313}$.

Em Malandragem, Lorca induz, com o corte, um tipo de leitura, pautada na idéia de espelhamento, que confunde o observador: a foto com corte pode causar a sensação de que se trata de pernas espelhadas. No original, a figura dos dois homens de corpo inteiro está dada, eliminando essa sensação. A idéia de espelhamento estende-se também à questão do reflexo das pernas na poça de água que, na foto original, é mais um elemento da fotografia. Na versão com corte, o reflexo é o assunto da fotografia.

Considerando a encenação e o corte da imagem, torna-se importante observar, por um lado, que o pseudoflagrante é um trabalho de composição do fotógrafo que antecede o ato fotográfico - existe uma pré-intenção em realizar

email, a secretária de Lorca, Angella Souza, transmite o retorno de Lorca às minhas perguntas e informa que Malandragem foi realizada no bairro do Brás.

${ }^{313}$ Ver COSTA, Helouise e SILVA, Renato Rodrigues, op. cit., p. 46: “(...)tudo foi meticulosamente arquitetado. A faixa negra que cruza a foto no sentido horizontal divide a composição em dois retângulos, aludindo ao mesmo tempo à materialidade e à continuidade da superfície da imagem fotográfica. A silhueta que se encontra no primeiro plano está refletida de modo invertido, transcrita como em um espelho, no segundo plano, ironizando a inutilidade do olhar que penetra a fotografia ansioso em reconstituir a cena original (...) Cansado de um exercício que afinal se mostra inútil, nosso olhar vagueia, já se acostumando à irreversibilidade desse movimento (...)

(....) um aguçado jogo conceitual amarra a leitura desta imagem. Em Malandragem German Lorca destila uma dupla ironia: com o observador que consome a fotografia como se fosse o real, quando de fato trata-se de uma linguagem e com o fotógrafo que, acreditando dominar o código fotográfico, está preso às suas determinações mais amplas. Na verdade o que German Lorca discute é a característica essencial imputada à fotografia de 're-produção' do real. Sua intenção é precisa: mostrar que a fotografia registra o real, mas que esse real é codificado para ser imagem. Se o observador desvelar as intenções as intenções ideológicas da perspectiva terá em mãos, com a fotografia, um poderoso meio de análise da natureza. 
a fotografia. Por outro, o corte será um trabalho de composição que sucede esse ato. Nesse sentido, em um pseudoflagrante com corte, Lorca pode compor a fotografia duas vezes.

No entanto, em um flagrante, Lorca pensará na composição uma vez, somente depois de tê-la realizado. Aí então efetuará, ou não, o corte.

A fotografia Menina na Chuva [Ilustração 3.8] é outro exemplo que dá conta dessa dupla composição:
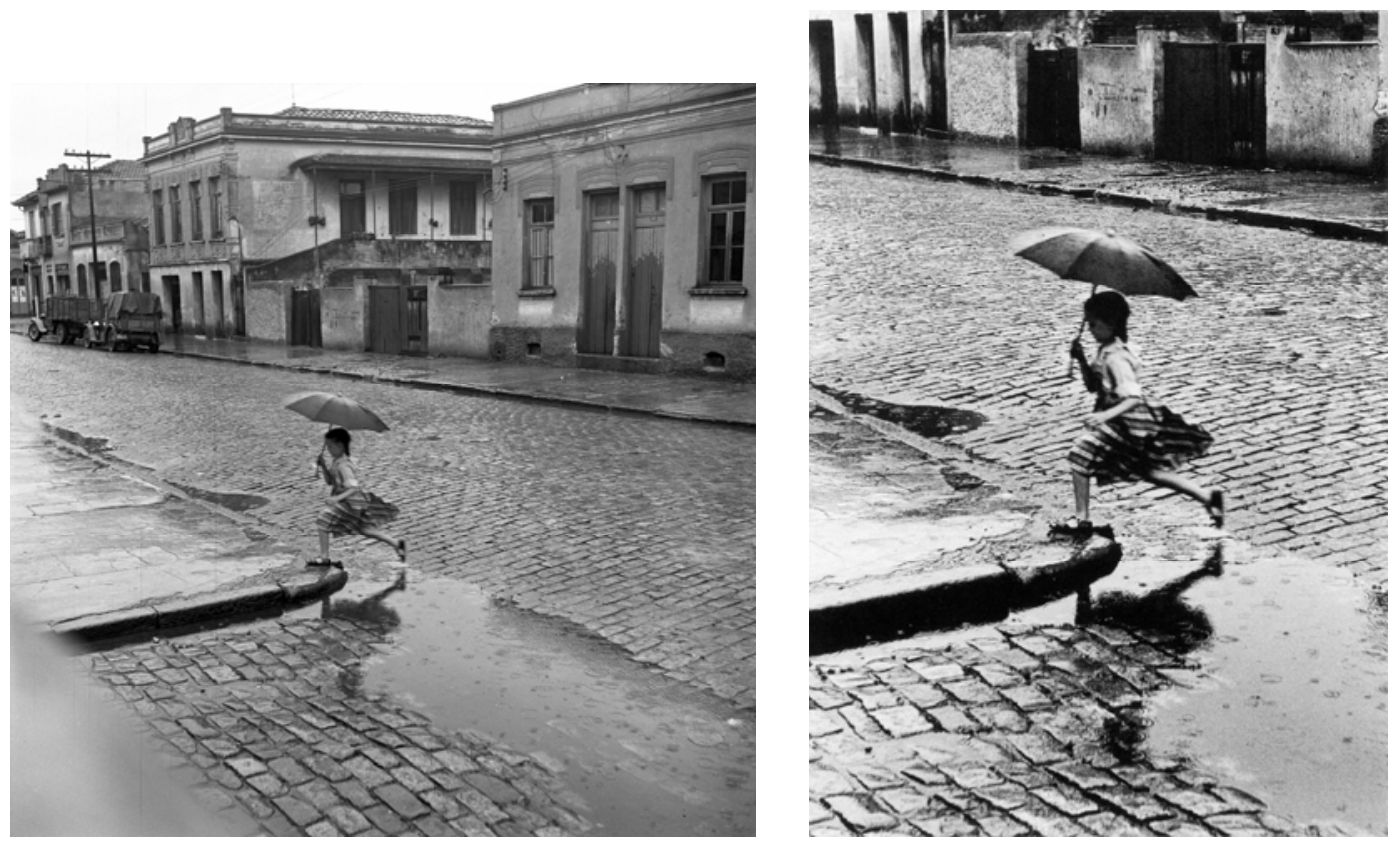

Ilustração 3.8: German Lorca, Menina na Chuva, 1950. Original e com corte. Acervo de German Lorca e Coleção Museu de Arte Moderna de São Paulo.

Note-se que na fotografia original a figura da menina está distante, as casas é que chamam atenção nessa fotografia. Na fotografia com corte a figura da menina é aproximada, partindo principalmente da idéia que Lorca já tinha sobre como queria a fotografia. Além disso, uma questão técnica imperativa - a interferência no canto esquerdo inferior da imagem original -, certamente influiu para o tipo de corte na imagem. 
Em A Procura de Emprego ${ }^{314}$ [llustração 3.9], um flagrante, a composição se dará a partir do corte.

Nessa fotografia, assim como em Malandragem, German Lorca também realiza um corte de grande porte no original. Porém, em A Procura de Emprego, a cena não será transformada totalmente (Malandragem se converte em uma imagem de cunho insólito quando Lorca mostra somente parte das pernas dos homens). Em A Procura de Emprego, Lorca enfatiza a cena que lhe interessa, segundo seu conceito de foto de arte: "quando uma cena chegava aos meus olhos, na minha concepção de arte eu fazia ${ }^{315 " . ~}$
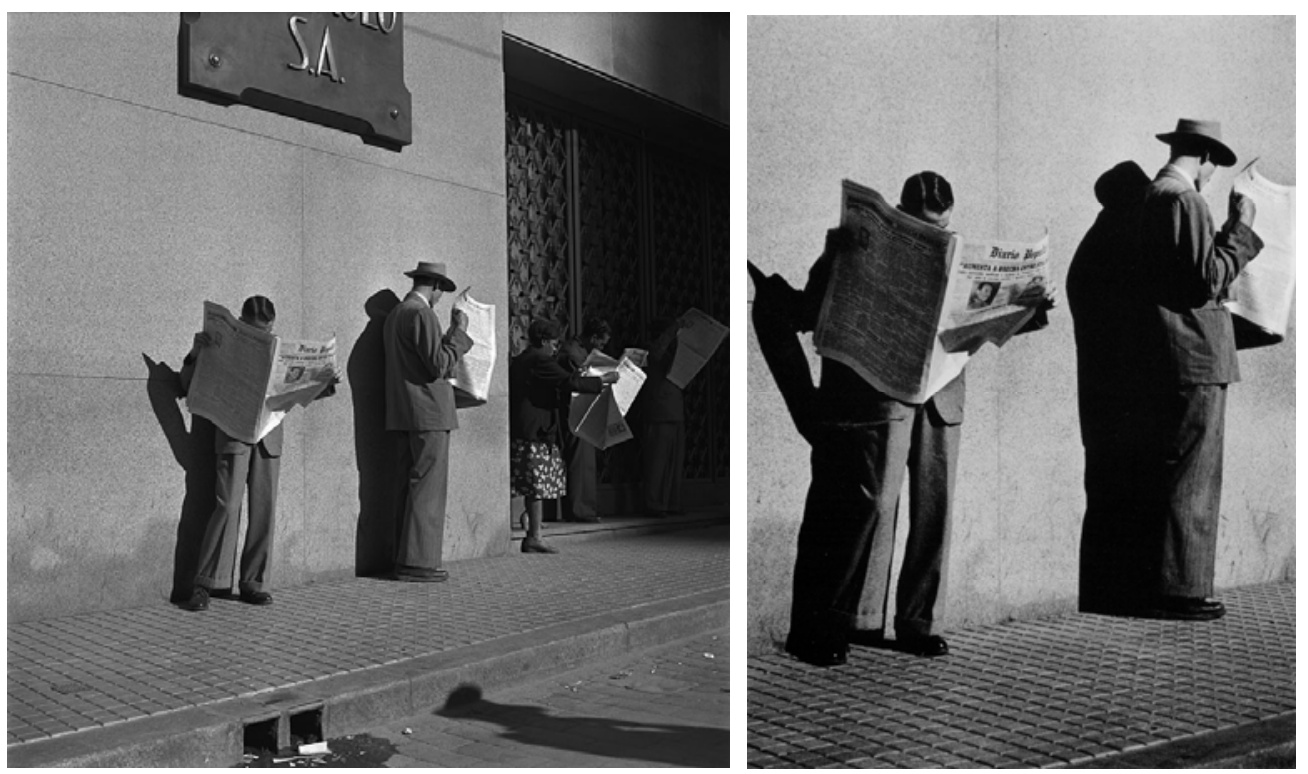

Ilustração 3.9: German Lorca. A procura de emprego, 1950. Original (à esquerda) e com corte (à direita). Acervo de German Lorca e Coleção Museu de Arte Moderna de São Paulo.

A fotografia original nos transmite uma idéia de espontaneidade, o que leva a crer que Lorca teria, como o fez, flagrado o fato: nota-se que as pessoas

\footnotetext{
${ }^{314}$ A fotografia A Procura de Emprego ilustrou o convite da exposição São Paulo por German Lorca, que o fotógrafo realizou no ano 2000 no Museu de Arte Moderna de São Paulo. Na legenda da imagem no verso do convite lê-se. $A$ Procura de Emprego, 1951, Praça Antonio Prado esquina Rua João Brícola, SP, criando um registro do local em que a cena se passou. Segundo German Lorca, em entrevista concedida à autora, a fotografia foi realizada nesse local de fato, e as pessoas na fila teriam comprado o jornal no Diário Popular para ler os classificados de emprego. Essas pessoas estavam na fila encostadas no prédio do banco Banespa, esperando sua abertura para procurar emprego. Tal fotografia integrou a primeira mostra individual que o fotógrafo realizou no local, em 1952.

315 Depoimento concedido à autora em 15 de abril de 2004. Lorca se referia ao fato de que utilizava a fotografia profissionalmente para viver, mas aproveitava para fazer fotografia de arte, sempre que uma cena aparecia para ele e se inseria em seu conceito de arte.
} 
da fila estão absortas lendo o jornal, cada uma em um tipo de posição e estabelecendo relações diferentes com o jornal. A primeira pessoa encostada na grade está com o rosto completamente "afundado" no jornal, enquanto a terceira o lê a certa distância. É claro que tal fato poderia ter sido igualmente arranjado, principalmente pela imobilidade das pessoas, "à espera" na fila, o que facilitaria o trabalho de encenação.

Seja como for, a imagem original nos fornece algumas pistas da situação da fotografia: uma fila, pessoas lendo jornal (não identificável qual jornal na foto original) e uma placa onde só é possível ler o S.A.

$\mathrm{Na}$ fotografia cortada, German Lorca enfatiza apenas os dois últimos homens da fila, obviamente por razões composicionais e plásticas: note-se a simetria entre as imagens e a questão da sombra na parede.

Com essa fotografia acontece o inverso de quando se olha o original: a sensação é de fotografia posada. Talvez para uma propaganda do Diário Popular? (na fotografia com corte é possível identificar que os homens lêem esse jornal).

Já a fotografia Apartamentos [llustração 3.10] foi capa do boletim ano VI, $\mathrm{n}^{\circ} 68$ de dezembro de $1951^{316}$, o que significa que ter sido realizada nesse ano, ao invés de 1952.

Com ela German Lorca participou do concurso Alejandro del Conte, realizado em 1952, na Argentina (talvez por isso tenham datado a fotografia como sendo deste ano), em homenagem ao fotógrafo Alejandro Del Conte ${ }^{317}$,

\footnotetext{
${ }^{316}$ Em 1997 essa fotografia passaria a integrar o Acervo da Coleção Pirelli Masp de Fotografia e em 2000, da coleção do Museu de Arte Moderna de São Paulo.

317 Alejandro Del Conte seria considerado um fotógrafo emblemático na "Arte fotográfica de sua Pátria e Continente". Ver artigo sobre o falecimento de Alejandro del Conte no Boletim Ano VI, de março/abril de 1952, págs. 8, 9 e 31. Ver
} 
tendo recebido o primeiro prêmio, juntamente com Eigyrio Sato, também fotógrafo do Bandeirante ${ }^{318}$.
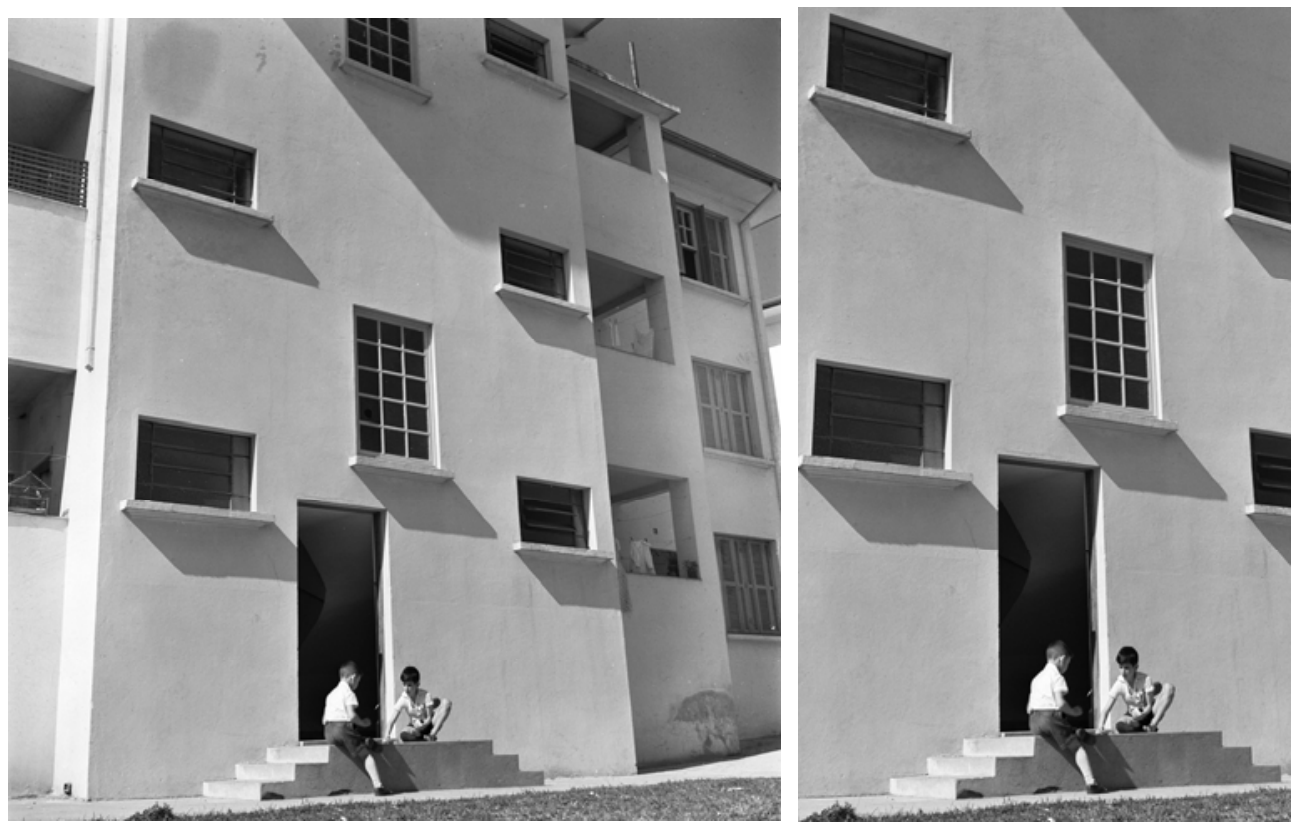

Ilustração 3.10: German Lorca. Apartamentos, 1951. Fotografia original (à esquerda) e com corte (à direita). Acervo de German Lorca e Coleção Museu de Arte Moderna de São Paulo.

A fotografia Apartamentos, segundo informações de German Lorca ${ }^{319}$, foi um flagrante que ele captou em um conjunto de apartamentos populares que pertencia ao IAPI, atualmente conhecido como INPS, na Mooca.

Pela fotografia original não é possível ter certeza se o fato foi flagrado ou encenado. Aparentemente os meninos brincam espontaneamente, mas bem poderia ser uma situação forjada.

$\mathrm{Na}$ fotografia com corte, percebe-se o claro interesse de Lorca por questões compositivas. O fotógrafo elimina da imagem as outras partes do prédio, criando uma fotografia de beleza e rigor formais e geométricos:

"Concurso 'Alejandro Del Conte - magnífico êxito da representação bandeirante", no Foto-Cine Boletim Ano VII, $\mathrm{n}^{\circ} 78$ de 1952.

${ }^{319} \mathrm{Em}$ palestra realizada no Itaú Cultural em 04 de outubro de 2005, referida anteriormente na dissertação. 
observe-se as janelas e respectivas sombras, com relação a porta, a escada e a verticalidade do prédio.

\section{Considerações finais}

Dentro do contexto apresentado nesta dissertação, acredito que algumas considerações são necessárias para concluir o pensamento ao redor da prática do flagrante, do pseudoflagrante e do corte, na fotografia de German Lorca.

A primeira questão que eu gostaria de apontar aqui seria aquela contida logo no início do capítulo 1: até que ponto a crença na autenticidade da espontaneidade da fotografia Menina na Chuva seria questionada se não fosse o próprio German Lorca a nos informar sobre sua concepção e execução totalmente forjada?

Penso que, de fato, esta questão é um ponto de partida importante a se considerar. Para o observador comum, o fato de uma fotografia ser um flagrante real ou forjado talvez não pese tanto em sua avaliação. Para ele pode ser que o que importa, no final, é a sensação de flagrante que a cena the passa. Porém, se nos propusermos a pensar a fotografia como um elemento significativo dentro de um determinado processo histórico, aquele "detalhe" certamente pesará.

Sob essa perspectiva, teremos de levar em conta as razões pelas quais um fotógrafo decide que vai forjar uma cena, com a idéia de fazer com que ela se pareça espontânea. 
Por trás da aparente ingenuidade e gratuidade do ato de encenar um flagrante, em busca de um efeito de espontaneidade, se esconde o olhar do fotógrafo totalmente estruturado por cânones e critérios de gosto que foram sendo estabelecidos ao longo da história da fotografia que remonta à segunda metade do século XIX.

Se para o fotógrafo oitocentista encenar um flagrante era um recurso utilizado, em último caso, para driblar entraves técnicos e operacionais, para o fotógrafo moderno - de posse das câmaras portáteis de $35 \mathrm{~mm}$ que possibilitam exatamente a obtenção de instantâneos -, a encenação será uma prática compositiva, levada a cabo com o intuito de atingir parâmetros de uma fotografia de arte.

Visível já no século XIX, mas constituindo-se com força a partir dos anos de 1920 e 1930, a busca do flagrante, do "instante decisivo" foi se tornando um dos parâmetros mais aceitos para configurar a fotografia "artística", ou "de arte". E isso porque sempre se acreditou que, por trás dessa busca, ou por trás do sucesso dessa captação do momento fugidio, estava o olhar especial do fotógrafo, o olhar autoral. $\mathrm{O}$ olhar que conseguia tirar da máquina fotográfica a sua relação puramente mecânica com o mundo, concedendo-lhe alguma humanidade. E para muitos, justamente nessa capacidade de "humanizar" a fotografia era que se tornava possível o fotógrafo igualar-se ao artista tradicional.

Como espero ter demonstrado aqui neste trabalho, German Lorca se utilizou muito bem dessa possibilidade de produzir fotografias de grande interesse tanto por meio de flagrantes como de pseudoflagrantes. Em ambos 
os casos, ele atingiu aquilo que sempre procurou ao longo dos seus sessenta anos de carreira: o status de fotógrafo de arte, o status de artista.

Neste sentido, o interesse em conceber uma composição que se adapte às demandas do que seu meio acredita ser uma fotografia de arte, será definitiva para que Lorca opte por flagrar ou encenar uma tomada.

Quando Lorca fez o pseudoflagrante com Eunice, sua sobrinha, ele tinha em mente uma concepção artística do tipo de fotografia que queria obter: ele queria produzir uma cena que criasse a sensação de ter captado um instante corriqueiro dentro de uma cidade - uma criança apressada sob a chuva - mas extremamente delicado e poético, se bem captado pela câmara fotográfica. Chuva e criança, a fragilidade da menina frente as manifestações naturais na cidade grande e vazia. Uma cena que possuía todos os elementos para agradar a um público e a um grupo de fotógrafos e críticos de fotografia interessados em ver acontecer em São Paulo uma fotografia de rua que desse conta dessas cenas despretensiosas mais extremamente líricas, que ocorrem no dia-a-dia da cidade. Interessado em produzir esta cena, Lorca observou antes a rua de sua janela, estudou o ambiente e imaginou a foto.

Uma vez obtida a imagem que antecipadamente concebeu e produziu, com a ajuda da garotinha, o que faz Lorca?

O fotógrafo rearticula os elementos da fotografia, enfatiza o que lhe interessa, corta aquilo que se demonstra demasiado para que ela se aproxime da idéia que ele previamente concebera.

Vista depois de todo esse trabalho de concepção, produção e edição, ali está Menina na Chuva que, até a declaração de seu autor, todos acreditavam ser o fruto de um olhar virgem e original, totalmente isento de qualquer conceito 
prévio de como deveria ser uma fotografia, atento apenas ao instante, ao fugidio.

No entanto, Lorca, no processo de produção daquela e de outras fotos, na verdade praticava possibilidades compositivas já percebidas em fotografias às quais tinha acesso. Tanto antes de realizar a fotografia - no âmbito da concepção e da produção da foto - quanto como depois disso - no momento dos reenquadramentos e dos cortes efetivos -, o fotógrafo parte de modelos concretos.

Creio que era essa prática de compor a fotografia - com o "antes" e o "depois" de apertar o botão -, o que interessava mais a Lorca.

Tais considerações não significam, no entanto, que as fotografias de Lorca - aqueles pseudoflagrantes - sejam inferiores, ou "menos artísticas". Elas apenas atestam que o artista partiu de parâmetros pré-existentes e soube, a partir deles, produzir obras que são suas. Como praticamente todos os outros fotógrafos e mesmo artistas plásticos

Outro exemplo, a meu ver emblemático, de como o pseudoflagrante pode ser extremamente interessante, capaz de forjar uma cena inquietante e que nos deixa sempre perplexos quando a observamos, é a fotografia Malandragem. Nela, a questão da composição e do valor artístico impera sobre qualquer outro aspecto.

Se Lorca estava passando na rua próxima ao bar em que encontrou os homens que iriam posar para ele, certamente estudou o local, observou a poça de água no chão, imaginou o jogo de espelhamento que poderia ser causado com a posição dos dois homens, um de frente para o outro. 
Mas quando ele, de posse da imagem ampliada, decide corta-la radicalmente, de modo a enfatizar aquele espelhamento, não seria lícito perguntar se o pseudoflagrante já não estaria ali, como uma possibilidade localizada na raiz daquela atitude?

Porém, o que é mais interessante é que Lorca pode obter resultados semelhantes em fotografias em que ele efetivamente flagrou as pessoas ali retratadas.

Certa vez, quando o entrevistava, perguntei-Ihe quais fotografias de sua autoria ele considerava efetivamente como sendo fotos de autor, fotografia de arte. Entre a grande quantidade de obras que Lorca produziu nessas décadas de trabalho, ele mencionou, justamente, A Procura de Emprego: um flagrante que, de tão reestruturado após a tomada da cena, parece, de fato, um pseudoflagrante.

Não é mesmo tênue a linha que separa o flagrante de seu falseamento?

\section{§§§§§}

\section{Bibliografia}

\section{Livros e teses:}

AZEVEDO, Militão Augusto de. Album comparativo da cidade de São Paulo/1862-1887. São Paulo: Prefeitura do Município de São Paulo: Secretaria Municipal de Cultura, 1981.

ANDRADE, Joaquim Marçal Ferreira de. História da Fotorreportagem no Brasil - A fotografia na Imprensa do Rio de Janeiro de 1839 a 1900. Rio de Janeiro: Elsevier, 2004. 
ARGAN, Giulio Carlo. História da Arte Italiana: da Antiguidade a Duccio. São Paulo: Cosac\&Naify, 2003, vol. 1.

História da Arte Italiana: de Giotto a Leonardo. São

Paulo: Cosac\&Naify, 2003, vol. 2

AVANCINI, Atílio José. Em flagrante - Leitura de fotografias de rua do cotidiano da cidade de São Paulo nas duas primeiras décadas do século XX. Dissertação de mestrado apresentada à Escola de Comunicações e Artes da Universidade de São Paulo, São Paulo, 1999.

BANDEIRA DE MELLO, Maria Teresa. Arte e fotografia: o movimento pictorialista no Brasil. Rio de Janeiro: Funarte, 1998. Col. Luz e reflexão.

BARTHES, Roland. A Câmara Clara. Rio de Janeiro: Editora Nova Fronteira, 1984.

BAUDELAIRE, Charles. Sobre a Modernidade. Rio de Janeiro: Paz e terra: 1996.

BORDIEU, Pierre. La Fotografia como un Arte Intermédio. México: Editorial Nueva Imagen, 1979.

CAMARGO, Mônica Junqueira de; MENDES, Ricardo. Fotografia, cultura e fotografia paulistana no século XX. Secretaria Municipal de Cultura de São Paulo. São Paulo: 1992

CARTIER-BRESSON, Henri. Fotografiar del Natural. Barcelona: Editorial Gustavo Gilli, 2003.

CLARKE, Graham. The Photograph. Oxford: Oxford University Press, 1997.

COSTA, Helouise; SILVA, Renato Rodrigues. A fotografia moderna no Brasil. São Paulo: Cosac\&Naify, 2004. , Helouise. Um olho que pensa: estética moderna e fotojornalismo.

Tese de doutoramento apresentada à Faculdade de Arquitetura e Urbanismo da Universidade de São Paulo. São Paulo: 1998.

DELELLIS, Rosana. Catedral da Sé: Arte e engenharia na recuperação do patrimônio. Rosana Delellis, Artur Lescher, latã Canabrava; [tradução inglês], Camilo Rocha. São Paulo: FormArte, 2002.

EVANS, Jessica; HALL, Stuart. (org.) Visual Culture: the reader. Londres: Sage Publications, 2002 ( $3^{\text {a }}$ edição).

FABRIS, Annateresa (org.) Arte e política - algumas possibilidades de leitura. São Paulo: FAPESP; Belo Horizonte: C/Arte, 1998. 
. Fotografia: usos e funções no século XIX. São Paulo:

Edusp, 1991.

. Identidades Virtuais - uma leitura do retrato fotográfico.

Belo Horizonte: Editora UFMG, 2004.

. Fragmentos Urbanos - representações culturais. São

Paulo: Studio Nobel, 2000.

FERNANDES JR. Rubens. Labirintos e Identidades - Panorama da Fotografia no Brasil (1946-98). São Paulo: Cosac\&Naify/Centro Universitário Maria Antônia, 2003 ( $1^{\text {a }}$ edição).

FERNANDEZ, Horácio (ed). Fotografia Pública - Photography in Print 19191939. Museu Nacional Centro de Arte Reina Sofia. Madrid: Aldeasa, 2000.

FERREZ, Gilberto. A Fotografia no Brasil 1840-1900. Rio de Janeiro: Fundação Nacional de Arte/Fundação Nacional Pró-Memória, 1985.

FONTCUBERTA, Joan. Crisis de História. Barcelona: Actar, 2005.

GRANGEIRO, Cândido Domingues. As artes de um negócio: a febre fotográfica: São Paulo 1862-1886. Campinas: Mercado de Letras; São Paulo: FAPESP, 2000.

GOMBRICH, E.H. História da Arte. Rio de Janeiro: Editora Guanabara, 1988. trad. Álvaro Cabral, $4^{\mathrm{a}}$ edição.

KOSSOY, Boris. Origens e expansão da fotografia no Brasil. Rio de Janeiro: Funarte, 1980.

KRUSE, Petra; WILLINGHÖFER, Helga (coord.) German Photography 18701970. Bonn: Kunst -und Ausstellungshalle der Bundesrepublik Deutschland 1997. trad. Dumont.

LYONS, Nathan. Photographers on photography. New Jersey: Prentice-Hall, Inc, Englewood Ciffs; New York, The George Eastman House, 1966.

MACHADO, Arlindo. A ilusão espetacular, introdução à fotografia. São Paulo: Brasiliense, 1984, Col. primeiros vôos.

MANZON, Jean. Flagrantes do Brasil. Rio de Janeiro: Gráficos Bloch S.A, 1950.

NEWHALL, Beaumont. The history of photography from 1939 to the present day. New York, the Museum of Modern Art, 1982. 
PADILHA, Márcia. A cidade como espetáculo: publicidade e vida urbana na São Paulo dos anos 20.. São Paulo: Annablume, 2001.

REZENDE, Eliana Almeida de Souza. Alquimia sedutora substanciada em imagem: a crônica fotográfica de São Paulo nas primeiras décadas do século $X X$. Dissertação de mestrado apresentada à Pontifícia Universidade Católica de São Paulo. São Paulo: 1996.

SALLES, Ricardo. Guerra do Paraguai, memórias e imagens. Rio de Janeiro: Edições Biblioteca Nacional, 2003.

SALOMON, Erich. Berühmte Zeitgenossen in unbewachten Augenblicken. Schirmer/Mosel Mündchen, 1978.

Schirmer/Mosel, 2004

Erich Salomon - Photographien 1928-1938.

SCHARF, Aaron. Arte y fotografia. Madri: Alianza Editorial, 1994.

SONTAG, Susan. Ensaios sobre fotografia. Rio de Janeiro, Arbur, 1981.

SOUSA, Jorge Pedro. Uma história crítica do fotojornalismo ocidental. Chapecó: Grifos; Florianópolis: Letras Contemporâneas: 2000.

STIEGLITZ, Alfred. Camera Work - A pictorial guide. Edited by Marianne Fulton Margolis.

STAROBINSKI, Jean. A Invenção da Liberdade, 1700-1789. São Paulo: Editora Unesp, 1994 (Coleção Studium).

SZARKOWISKI, John. Photography until now. New York: Bulfinch Press, Bulfinch Press/Little, Brown and Company, 1989.

TALBOT, Willian Henry Fox. The Pencil of Nature. New York: Da Capo Press, 1969

TRACHTENBERG, Alan (org). Classic Essays on Photography. New Haven, Conn: Leete's Island Books, 1980.

TORAL, André. Imagens em Desordem: A iconografia da Guerra do Paraguai (1864-1870). São Paulo: FFLCH - USP/ Humanitas, 2001.

TURAZZI, Maria Inez. Poses e Trejeitos - A fotografia e as exposições na era do espetáculo (1839/1889). Rio de Janeiro: FUNARTE e Rocco, 1995.

WESTERBECK, Colin; MEYEROWITZ, Joel. Bystander: A History of Street Photography. Boston: Bulfinch Press, 2001. 


\section{Catálogos:}

BIBLIOTHĖQUE NATIONALE DE FRANCE/SOCIETÉ FRANÇAISE DE PHOTOGRAPHIE. La Révolution de la photographie insantanée 1880-1900. Paris: 1996. Cahiers d'une exposition/15.

II BIENAL INTERNACIONAL DE FOTOGRAFIA DE CURITIBA. German Lorca fotografias. Curitiba, 1998.

COLEÇÃO PIRELLI-MASP DE FOTOGRAFIA. $7^{\mathrm{a}}$ e $14^{\mathrm{a}}$ edições. São Paulo: 1997/2005.

ESPAÇO PAUL MITCHELL Manhattan - New York 1966/1977: Fotografias de German Lorca. São Paulo: 2000.

FOTO-CINE CLUBE BANDEIRANTE. Catálogo do $8^{\circ}$ Salão Internacional de Arte Fotográfica. São Paulo: FCB, 1949.

INSTITUTO MOREIRA SALLES. Cadernos de Fotografia Brasileira- São Paulo 450 Anos (n.2). São Paulo: IMS, 2004. , São Paulo de Vincenzo Pastore. São Paulo:

IMS, 1997.

INSTITUTO DE RELAÇÕES CULTURAIS COM O EXTERIOR (IFA)/ SECRETARIA DE ESTADO DA CULTURA, PAÇO DAS ARTES/GOETHE INSTITUT: A fotografia na República de Weimar.

LI PHOTOGALLERY. French Quarter - New Orleans: Fotografias de German Lorca e Manuk.

MUSEU DE ARTE MODERNA DE SÃO PAULO. Cinqüenta 50. Curadoria: Felipe Chaimovich. São Paulo: MAM, 04 de jan. a 13 de março de 2005.

\section{Boletins do Foto-Cine Clube Bandeirante:}

- Ano II n'. 15, julho de 1947;

- Ano II n 16, agosto de 1947;

- Ano VI n. 38, junho de 1949;

- Ano IV n. 40, agosto de 1949;

- Ano IV n. 43, novembro de 1949;

- Ano V n. 49, maio de 1950;

- Ano $\vee n^{\circ} .50$, junho de 1950;

- Ano $\vee n^{\circ}$. 51, julho de 1950; 
- Ano $\vee n^{\circ} .56$, dezembro de 1950;

- Ano $\vee \mathrm{n}^{\circ} .57$, janeiro de 1951;

- Ano $\vee n^{\circ} .58$, fevereiro de 1951;

- Ano $\vee n^{\circ} .59$, março de 1951;

- Ano VI n. 61, maio de 1951;

- Ano VI n. 63, julho de 1951,

- Ano VI ñ. 65, setembro de 1951;

- Ano VI n. 66, outubro de 1951;

- Ano VI - n. 68, dezembro de 1951;

- Ano VI - n'. 69/70, janeiro/fevereiro de 1952;

- Ano VII - n'. 74, junho de 1952;

- Ano VII - $\mathrm{n}^{\circ}$. 75, julho de 1952;

- Ano VII - n. 76, agosto de 1952;

- Ano VII - n'. 78, outubro de 1952;

- Ano VII - n'. 81;

- Vol. XIII - nº. 148, Arte Fotográfica na 8a Bienal de São Paulo

\section{Periódicos:}

Revista O Cruzeiro:

- Ano XVI/1944: Edições de 01, 08, 15 e 29 de janeiro; 05,12,19 e 26 de fevereiro; 11, 18 e 25 de março; 01, 08, 15, 22 e 29 de abril; 06 e 13 de maio.

- Ano XVII/1945: Edições de 06 e 13 de janeiro.

Revista Life Internacional:

- Edição de 17 de Março de 1947;

- Edição de 01 de março de 1948;

- Edição de Junho de 1948;

- Edição de 31 de Janeiro de 1949 e 14 de Março de 1949.

Revista Íris:

- No. 5 de Maio de 1947;

- №. 6 de Junho de 1947;

- №. 7 de Julho de 1947 e no. 11, de dezembro de 1947; 
- Nos. 18 e 23, julho e dezembro de 1948;

- №. 25 de fevereiro de 1949. 